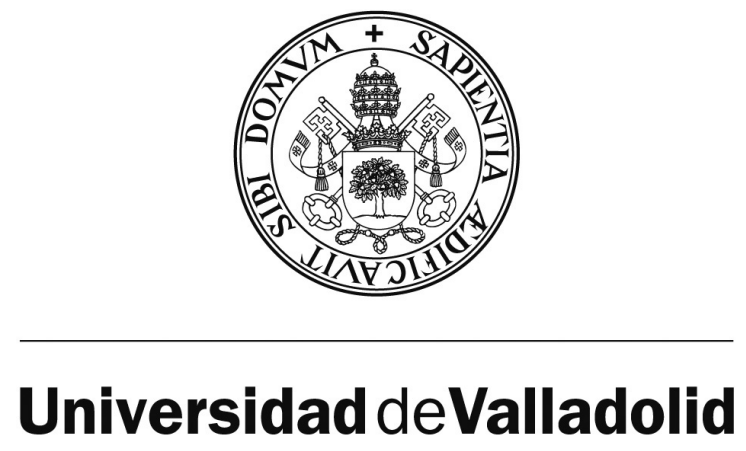

\author{
FACULTAD DE DERECHO \\ DEPARTAMENTO DE DERECHO CIVIL
}

TESIS DOCTORAL:

\title{
EL DEBER DE PROTECCIÓN: ANÁLISIS Y CONFIGURACIÓN EN LA DOGMÁTICA
}

Presentada por Gonzalo Álvarez Seura para optar al grado de doctor por la Universidad de Valladolid

Dirigida por: Cristina Guilarte Martin-Calero 
A la valiente Margarita, por sus incontables cuidados e inagotable cariño, a mi Madre, el inicio de todo, a mi mujer Carolina, la luz de mis días, a mis hijos Tomás y León, las únicas razones que conozco. 
"Para investigar la verdad es preciso dudar, en cuanto sea posible, de todas las cosas."

Descartes, Meditaciones Metafísicas, (1641) 


\section{ÍNDICE}

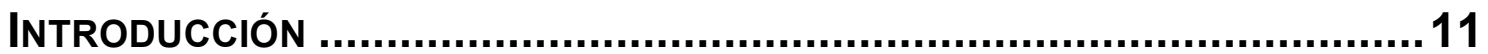

\section{CAPÍTULO PRIMERO:}

“UNA GÉNESIS DE LA CUESTIÓN"

I.- La relación obligacional ........................................................... 15

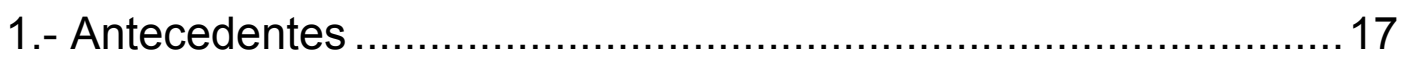

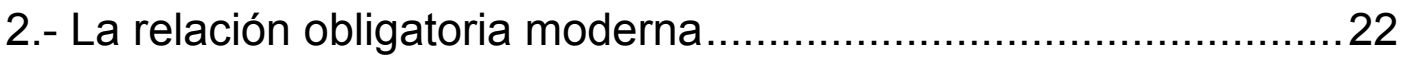

3.- Estructura de la relación obligacional ......................................... 30

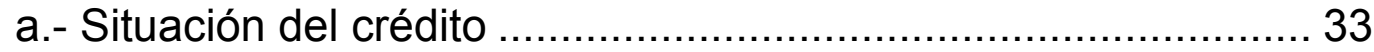

b.- Cargas y deberes de acreedor ............................................ 36

c.- Situación de la deuda ........................................................... 45

d.- Facultades del deudor ...................................................... 48

II.- Los deberes secundarios de conducta....................................... 51

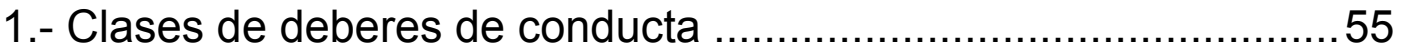

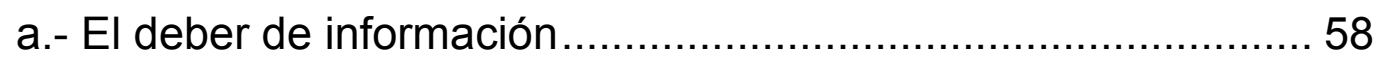

b.- El deber de reserva o confidencialidad.................................. 64

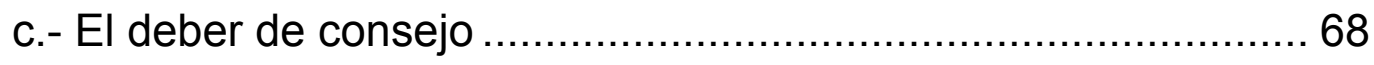

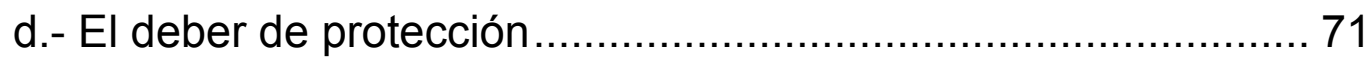




\section{Capítulo segundo:}

“EL DEBER DE PROTECCIÓN” 73

I.- Noción 73

II.- Teorías sobre su origen y naturaleza ............................................. 76

1.- Tesis precontractual............................................................ 76

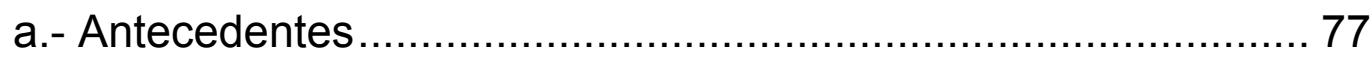

b.- Leading case: Linoleumfall .................................................... 80

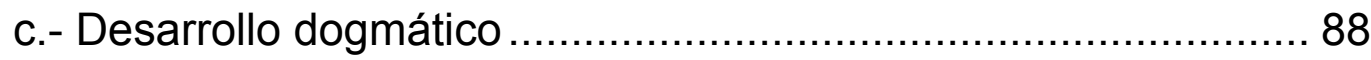

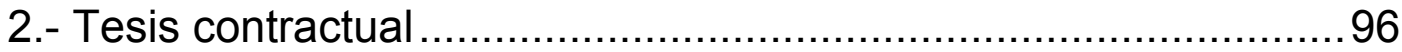

a.- Teoría de las lesiones contractuales positivas ....................... 96

b.- El nacimiento de la obligation de sécurité ............................. 102

c.- II doveri di protezione ......................................................... 116

3.- Tesis extracontractual ........................................................... 122

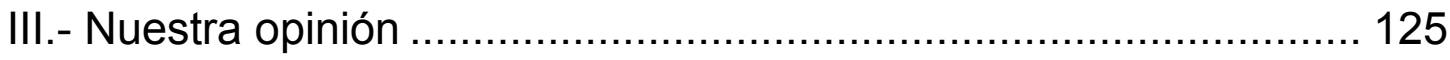

IV.- Configuración de los deberes de protección............................... 128

1.- Una cuestión previa: Deberes típicos y atípicos ........................128

2.- Premisas iniciales ............................................................ 130

a.- Característica elemental: Su autonomía.............................. 131

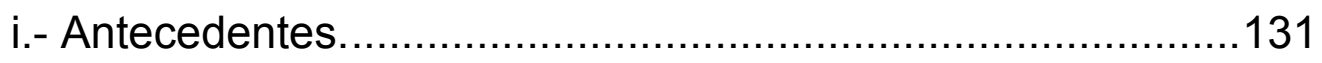

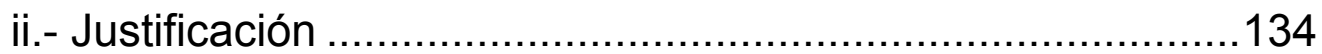

b.- Contenido: ¿Obligación de resultado o de medios? ................ 138

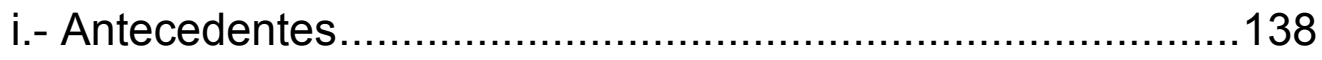

ii.- Implicancia en el deber de protección ..................................143

iii.- Deber de protección: Genuina obligación de resultado ......149 
V.- Ámbito de aplicación: Planteamiento del problema 151

1.- Nociones preliminares 154

2.- Criterio de determinación 158

\section{Capítulo Tercero:}

FUNDAMENTO NORMATIVO DEL DEBER DE PROTECCIÓN 163

I.- Principios generales de derecho .............................................. 164

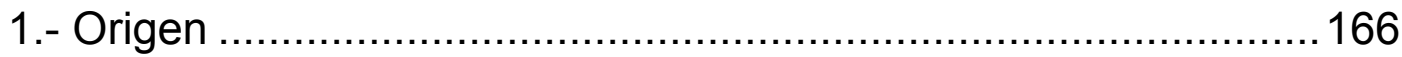

2.- Naturaleza y funciones ......................................................... 173

a.- Función informadora........................................................ 174

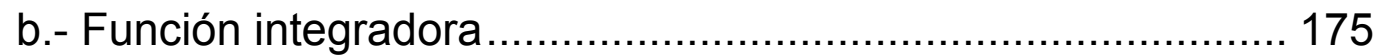

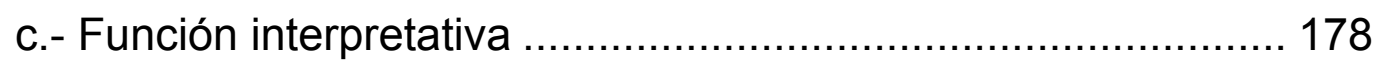

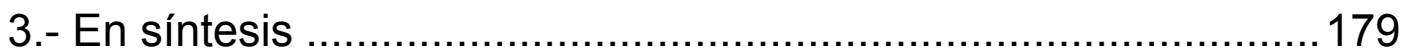

II.- El principio general de la buena fe .............................................. 180

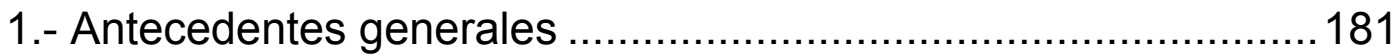

a.- En el Derecho romano........................................................ 181

b.- En el Derecho común .......................................................... 185

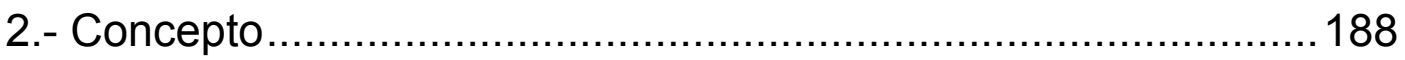

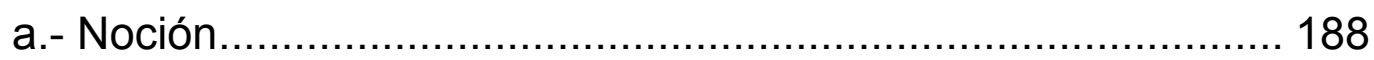

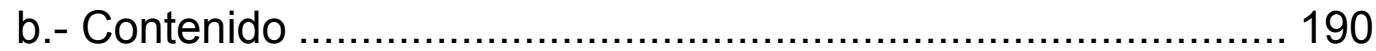

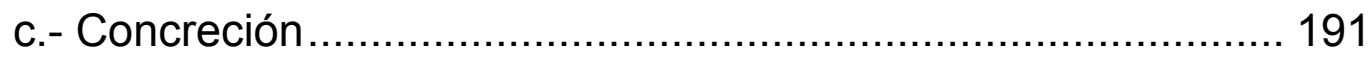

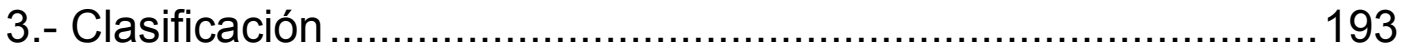

a.- Buena fe subjetiva ............................................................ 194

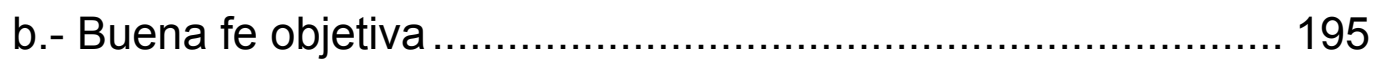

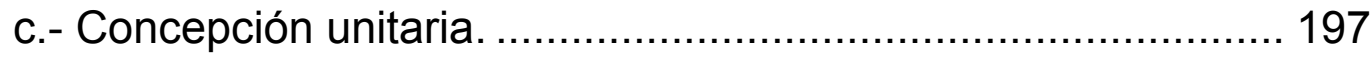


III.- Buena fe contractual: Fuente inmediata del deber de protección 199

1.- Antecedentes de la buena fe contractual.................................200

a.- Origen en Roma ............................................................... 200

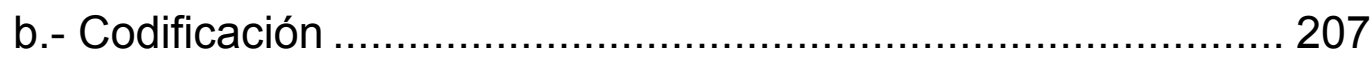

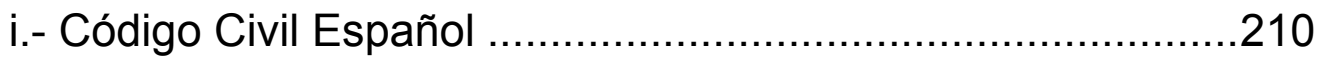

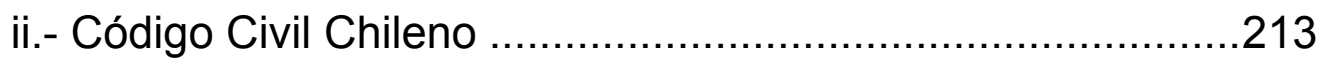

iii.- Otros Códigos Europeos..................................................218

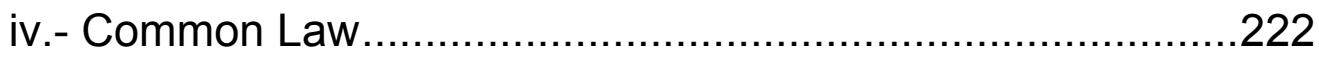

C.- La buena fe en el Derecho privado internacional y Soft Law . 224

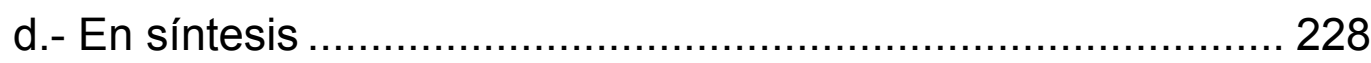

2.- La inclusión del deber de protección mediante la buena fe.......229

a.- El contenido de la buena fe contractual................................ 230

b.- Buena fe y la integración del contrato ................................. 234

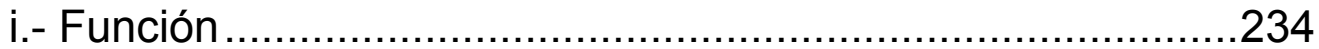

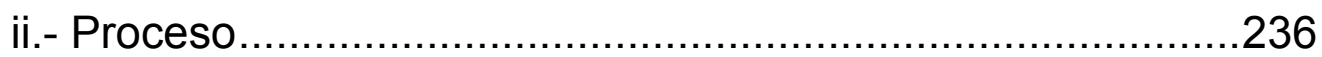

c.- Normatividad de la buena fe contractual ............................. 239

i.- Subfunción creadora o jurígena .......................................240

ii.- Subfunción correctora y modificadora ................................243

IV- Fuentes mediatas ............................................................... 245

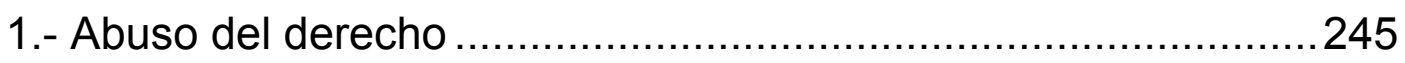

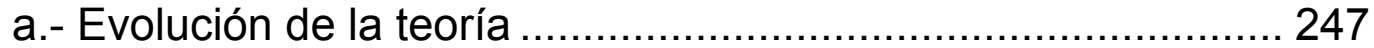

b.- Hipótesis de abuso del derecho en el deber de protección.... 254

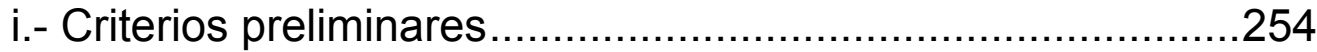

ii.- Infracción al deber: Ejercicio excesivo de un derecho.........256

2.- Instrumentos de Soft Law aplicables ........................................260

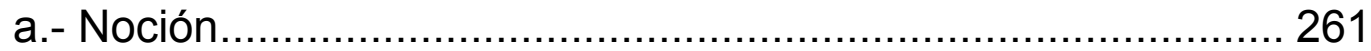

b.- Soft Law privado: Principios ………………......................... 262

i.- Principios de Derecho Europeo de la Responsabilidad Civil263 


\section{Capítulo cuarto:}

\section{Los DEBERES DE PROTECCIÓN EN EL SiSTEMA DE RESPONSABILIDAD Civil Chileno}

I.- Infracción de los deberes de protección: y sus efectos respecto las partes 268

1.- Inobservancia del deber de protección: extensión de la orbita

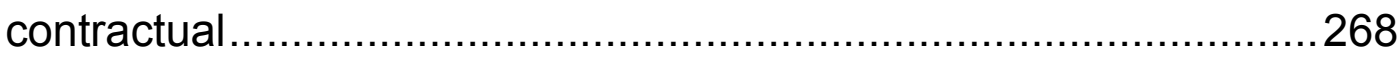

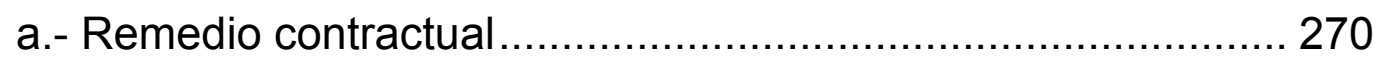

b.- Indemnización de perjuicios autónoma ................................. 271

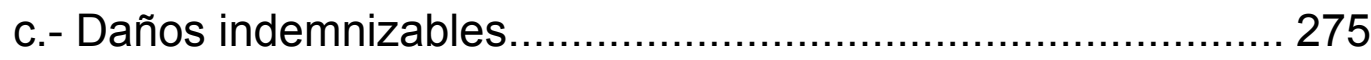

2.- Deber de protección y la responsabilidad contractual indirecta. 278

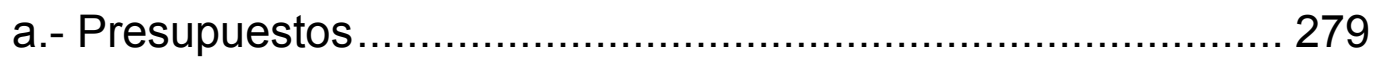

b.- Breve referencia al Derecho civil chileno............................... 284

C.- Infracción del deber por el auxiliar del deudor ....................... 290

II.- Infracción de los deberes de protección: y sus efectos respecto a

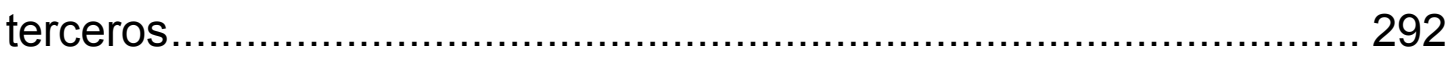

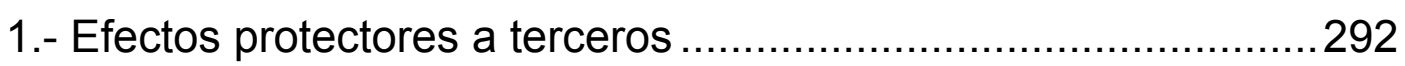

a.- La teoría de la relatividad del contrato................................... 295

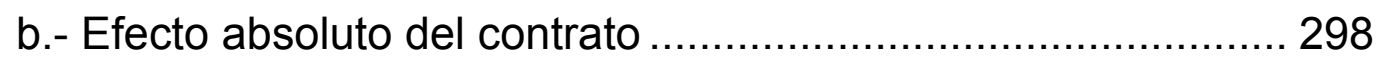

2.- Efecto expansivo del contrato y daños a terceros ..................... 302

a.- Víctimas por daño por repercusión, reflejo o rebote................ 304

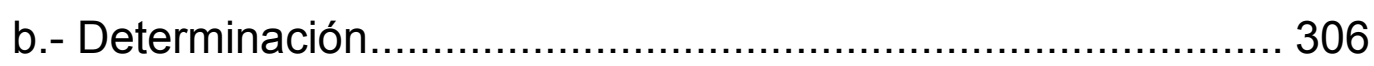

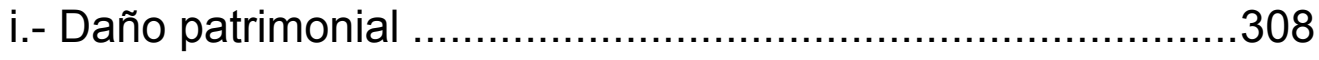

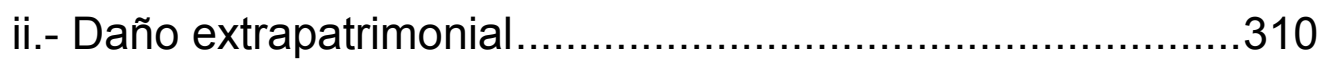


3.- Régimen especial de responsabilidad civil por infracción del deber de protección respecto del daño reflejo o rebote..... 313

a.- Presupuesto de antijuridicidad........................................... 315

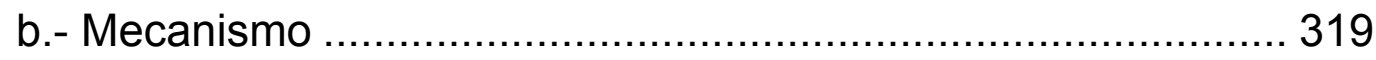

c.- Consecuencia del régimen especial ................................... 320

Conclusiones

325

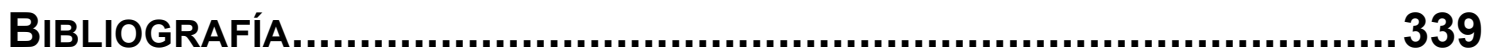

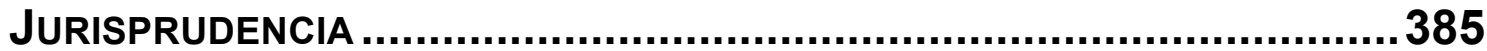




\section{EL DEBER DE PROTECCIÓN: ANÁLISIS Y CONFIGURACIÓN EN LA DOGMÁTICA}

\section{INTRODUCCIÓN}

El contenido de la relación obligacional moderna, se perfila como una entidad compleja y orgánica, donde confluyen entre sí variados elementos e intereses, transformándose en un verdadero mecanismo integrador de facultades, deberes y cargas. Bajo este nuevo paradigma, la deuda no puede concebirse exclusivamente como el deber del deudor de ejecutar la prestación prometida, ni el crédito solo como el derecho subjetivo a exigir la prestación.

Este carácter complejo y orgánico de la relación obligacional, afecta notoriamente la conformación típica y tradicional de su contenido, pues, junto al interés a la prestación, -que es el deber central y primario de la relación obligatoria-, aparece otro interés, consistente en que del vínculo no deriven daños para la persona o el patrimonio de cualquiera de las partes.

Ese otro interés, encuentra su concreción en la idea de los deberes de protección. Estos deberes secundarios de conducta, sobre los cuales centraremos nuestro objeto de estudio, cautelan el vínculo obligacional, protegiendo a las partes, en su persona o su patrimonio. Así, el deudor y el acreedor deben organizar su comportamiento 
prestacional de tal manera, que los intereses no prestacionales de la otra parte, no resulten lesionados durante el desarrollo de la relación obligacional.

Una investigación de esta naturaleza, supone enfrentarse virtualmente a ciertos dogmas de la teoría general de la responsabilidad contractual. Es una tarea ardua y nuestras pretensiones son modestas, precisamente por ello, nos hemos exigidos una obra sencilla y directa que busca plantear desde lo general a lo particular la ratio esencial de los deberes de protección. Estamos convencidos, que entre estas ópticas -particular y general-, existe un proceso de mutua influencia. $Y$ que, al igual que hay que recurrir a lo general, e incluso cuestionarlo, para abordar y resolver con eficacia las cuestiones particulares que presentan el fenómeno de los deberes en estudio, la consolidación de estas soluciones particulares pueden favorecer y acelerar un asentamiento convincente de nuestro instituto como categoría general en el sistema de responsabilidad civil.

Con la fe puesto en ello, hemos trazado como objetivo del presente trabajo, el contribuir a la tarea de precisar qué son los deberes de protección, bajo qué condiciones y circunstancias surgen en la relación obligacional, cual es su fundamento y, que consecuencias acarrean su infracción para el sistema de responsabilidad civil.

Para el persecución de tales propósitos hemos dividido la estructura de nuestra investigación en cuatros capítulos. 
El primero de carácter introductorio, ilustra los elementos mediante los cuales se edificará el escenario para la aparición del fenómeno de los deberes de protección. Así, se pone de manifiesto como el concepto de obligación, trastocada por el paso de los siglos, el desarrollo de la vida y economía moderna, da lugar a nuevas proyecciones e implicancias que colocan en su seno, una serie de conductas o deberes que sirven de apoyo a esta última, haciéndola más idónea para el logro del fin al cual se dirige. Bajo esta perspectiva, la obligación, pasa a ser concebida como una relación global que alberga diversos vínculos y situaciones jurídicas. El impulso que estos deberes secundarios de conducta será decisivo para la concreción de nuestro particular objeto de estudio en el panorama jurídico.

El segundo capítulo, se centra en fijar un marco teórico básico de los deberes de protección, que los sitúa como un fenómeno concreto y fehaciente en el ordenamiento jurídico. De esta manera intenta explicar satisfactoriamente la génesis y naturaleza de tales deberes, su configuración y el ámbito de aplicación de los mismos. El objetivo de este capítulo es encontrar notas comunes y reconocibles, en la mira de la construcción de una base dogmática maciza a la cual recurrir en las posteriores reflexiones sobre el instituto en comento.

El capítulo tercero, examina cual o cuales son la razones lógicas y jurídicas por la que el Derecho supone como justificado la incorporación de los deberes de protección en la relación obligacional. Para nosotros, el fundamento normativo es la esencia de toda construcción dogmática, por cuanto, dicho fundamento es aquello que transforma lo inmaterial de la idea, en lo sustancial de la decisión 
concreta, que resuelve el conflicto puesto ante el jurista. Todo conocimiento científico presupone la idea de una razón, que establezca por qué es correcta la aplicación de una consecuencia, de manera que sostenga y afirme su validez en un ordenamiento o sistema determinado. En este caso, tal razón -como se verá- se encuentra contenida principalmente en la idea del principio de la buena fe y de manera secundaria o mediata en la teoría del abuso del derecho y otras fuentes secundarias de Soft Law.

El cuarto y último capítulo, se ocupa de describir cuales son las eventuales proyecciones para el caso de inobservancia de los deberes de protección en el ámbito del sistema de responsabilidad civil chileno. En este orden de ideas, se analizaran, por separados los efectos que la infracción de los deberes en estudio tiene entre las partes de la relación obligatoria y los efectos de tal infracción respecto a terceros.

Debemos dejar expresa mención, que nuestro empeño en este trabajo no ha sido la reconstrucción dogmática de la responsabilidad civil, es más, nos hemos aproximado a ella de una manera más bien interesada, buscando soluciones que expliquen satisfactoriamente los problemas que generan el fenómeno de los deberes de protección. Tampoco en este especial campo de investigación hemos pretendido, en absoluto, realizar un análisis completo y exhaustivo de una materia tan rica en matices y consecuencias. Por el contrario, nuestro esfuerzo ha sido muchísimo más acotado y humilde, solo hemos querido llamar la atención sobre el papel fundamental que los deberes de protección están llamados a desempeñar en el sistema de responsabilidad civil. 


\section{CAPÍTULO PRIMERO}

\section{“UNA GÉNESIS DE LA CUESTIÓN"}

\section{I.- LA RELACIÓN OBLIGACIONAL}

Concordamos con aquel lector que no considerase un hecho demasiado novedoso que nos fijásemos en la noción de relación obligacional para iniciar el desarrollo de la presente investigación. Tal razonamiento resulta evidente, si se piensa en el vasto -y nutridotratamiento que se le ha dado por los juristas y autores clásicos a ésta cuestión. ${ }^{1}$

\footnotetext{
${ }^{1}$ Existen tantas definiciones de obligación como autores la han tratado, a modo de ejemplo: "Obligaciones o compromisos personales, son un lazo de derecho, que nos restringe a dar a otro alguna cosa, o bien a hacer o no hacer tal o cual cosa". POTHIER, Robert Joseph, Tratado de las Obligaciones, editorial Heliasta, Buenos Aires, 1993, p.1.; "La obligación o derecho personal, es una relación jurídica que asigna a una o varias personas la posición de deudores frente a otra u otras que desempeñan el papel de acreedores, y respecto de las cuales están obligadas a una prestación, ya positiva (obligación de dar o hace) ya negativa (obligación de no hacer). JOSSERAND, Louis, Cours de Droit Civil Positif Francais, t. II, París, 1932, p. 2. También JosseRAND, Louis, Derecho Civil, Trad. Santiago Cunchillos y Manterola, ediciones Jurídicas Europa-América, Buenos Aires, t. II, vol. I 1950.; "Una obligación es la necesidad jurídica a consecuencia de la cual una persona está sujeta hacia otra a dar hacer o no hacer alguna cosa". AUBRY ET RAU, Cours de Droit Civil Francais d'aprés la méthode de Zacharial. t. IV, París, 1902, p. 2.; "La obligación puede ser definida como una necesidad jurídica por ele efecto de la cual una persona esta sujeta respecto de otra a una prestación, ya positiva, ya negativa, es decir, a un hecho o una abstención", Colin Ambroise y CAPITANT Henry, Curso Elemental de Derecho Civil, t. III, 4ª ed. Española, editorial Reus, Madrid, 1960, p. 5.; "La obligación es un lazo de derecho por el cual una persona es compelida a hacer o a no hacer alguna cosa a favor de otra" PLANIOL, Marcel y RIPERT, Georges. Derecho Civil, Oxford University pressharla, $1^{a}$ ed., México. 1999. p. 613.; "La obligación es el vínculo de derecho por el cual una persona, debe satisfacer una prestación a favor de otra". RIPERT, Georges y BoulAnger, Jean, Tratado de Derecho Civil, Las obligaciones, vol. I, ediciones la Ley, Buenos Aires, 1964. p. 11.; "La obligación es un vínculo de derecho de aspecto pecuniario que une a dos o (más) personas, una de las cuales, es el deudor, está constreñida a una prestación a favor de otra, el acreedor". MAZEAUD, Henri, Lecciones de Derecho civil. Parte
} 
No obstante, sí nos parece llamativa la estrecha correspondencia existente entre la relación obligacional y nuestro objeto de estudio. Esta correspondencia resulta ser el mejor trayecto para iniciar nuestra marcha, debido a la estructura simbiótica que existe entre ambos conceptos jurídicos, estructura que intentará reunir las inaugurales interrogantes y adelantarnos en nuestras primeras convicciones.

Aislada pues nuestra intención, quisiéramos dedicar brevemente alguna atención a este tema, toda vez, que su examen resulta sustancial para lograr una comprensión integral de las problemáticas que presentan hoy los deberes de protección en el ámbito de la responsabilidad civil. Es por esta razón,-y no otra- que intencionalmente la hemos elegido como el punto de impulso de presente trabajo.

segunda, Obligaciones, vol., I, ediciones Jurídicas Europa-América, Buenos Aires, 1978. p.1.; "Por obligación o relación obligatoria, debe entenderse, en efecto, una relación entre dos sujetos (al menos), en virtud de la cual uno de ellos (deudor, llamado a veces promitente) queda obligado, esto es, sometido a un deber, o comprometido frente al otro (acreedor, llamado a veces estipulante) a cumplir con una prestación, o sea, a desarrollar una actividad determinada (comportamiento) patrimonialmente valorable y se atribuye al acreedor un correspondiente poder, que consiste en la pretensión a la prestación". MESsineo, Francesco, Manual de Derecho Civil y Comercial, t. IV, ediciones Jurídicas Europa-América, Buenos Aires, 1979. p. 3.; "La obligación no es sino el derecho personal considerado desde el punto de vista pasivo, es un vínculo jurídico por el cual una persona está sujeta, respecto de otra, a una prestación, un hecho o una abstención". GAUDEMET, Eugene, Teoría General de las Obligaciones, editorial Porrúa, $2^{a}$ ed., México, 1984, p. 25.; "Es el conjunto de normas reguladoras de las relaciones de crédito, siendo estas relaciones en que un derecho subjetivo atribuido a un sujeto corresponde un deber de prestar específicamente a favor de una persona determinada" Véase, ANTUNES VARELA, Joao de Matos, Das obrigaçes em geral, Almedina. 9a ed., Coimbra. 1996, p. 1.; "Obligación es un vínculo jurídico entre personas determinadas, en virtud del cual una de ellas se coloca en la necesidad de efectuar a la otra una prestación que puede consistir en dar una cosa, hacer o no hacer algo", ABELIUK, MANASEVICH, Rene, Las obligaciones, t. I, editorial Jurídica, $4^{a}$ edición, Santiago, 2001, p.17. 


\section{1.- ANTECEDENTES}

El concepto de obligación, ${ }^{2}$ es el resultado de una larga tradición histórica procedente del Derecho romano, donde la obligación se definió ya como vinculum iuris. La obligación es una situación bipolar, que se encuentra formada, por un lado, por la posición de una persona llamada deudor, y por otro por la posición de otra persona distinta llamada acreedor.

El acreedor es titular de un derecho subjetivo (derecho de crédito), que le faculta para exigir frente al deudor lo que éste es debido (prestación). Al mismo tiempo, como medida complementaria, el acreedor se ve investido de la posibilidad, en caso de incumplimiento, de proceder contra los bienes del deudor, así como investido también de un serie de facultades para la defensa de sus intereses. La segunda faceta o el segundo polo es la posición del deudor. El deudor es sujeto de un deber jurídico (deuda), que le impone la observancia del comportamiento debido y le sitúa en el trance de soportar, en otro caso las consecuencias de su falta. ${ }^{3}$

\footnotetext{
${ }^{2}$ De los Mozos, señala en este sentido: "Se denomina obligación (obligatio), ya desde el Derecho romano clásico, o aún preclásico, a una "relación jurídica" por la que una persona, llamada acreedor, tiene derecho a exigir de otra, llamada deudor, una determinada prestación, hallándose amparado el derecho subjetivo que nace de esta relación por una acción personal (actio in personam). Y agrega: "De acuerdo con esta precisión, la tradición pandectista coloca a las obligaciones entre los derechos personales, por contraposición a los derechos reales, viniendo de este modo a constituir una de las categorías más importantes de los derechos patrimoniales, y, por supuesto, el elemento básico de todo tráfico jurídico" Véase, DE LOS Mozos, José Luis, "Concepto de obligación", Revista de Derecho Privado, Madrid. 1980, pp. 980 y ss.

${ }^{3}$ Véase, en este sentido, DíEZ-PICAZo, Luis y Gullón, Antonio, Sistema de derecho civil, vol. II: El contrato en general. La relación obligatoria. Contratos en especial. Cuasicontratos. Enriquecimiento sin causa. Responsabilidad extracontractual, Tecnos, $9^{\text {a }}$ edición, $8^{a}$ reimpresión, Madrid, 2003, pp. 119 y ss.
} 
La perspectiva tradicional, se centra especialmente en la posición del deudor y se la opone, frecuentemente, al derecho personal del acreedor. Esta cotidiana visión, (vinculum iuris) se remonta en el Derecho romano al concepto de la "obligatio" ${ }^{4}$, sin embargo su evolución y análisis no esta libre de dificultades ni mucho menos detenta la paz de lo cotidiano.

La "obligatio," constituye un sustantivo abstracto que designa la acción derivada del verbo obligare, el que, a su vez, se compone del prefijo " $b$ " y de la forma verbal simple "ligare". De acuerdo con los diccionarios especializados, la fórmula verbal "obligo", as, are, tiene los siguientes significados etimológicos: a) atar juntos, reunir, ligar, envolver, vendar (especialmente en algunos pasajes de Cicerón, relativo a las vendas de una herida); b) ligar, encadenar; c) en otro sentido, referido al sujeto, hacerse culpable de una falta $y$, por conexión, hipotecar o empeñar, en un sentido lato; d) exigir al sujeto hacerse responsable; e) comprometerse a seguir los actos o jurar obediencia a los actos de alguno. ${ }^{5}$

\footnotetext{
${ }^{4}$ Señala Rodríguez Ennes sobre el origen de la obligatio: La palabra obligare es relativamente antigua, aparece ya en las comedias de Plauto y significa "atar". En el lenguaje jurídico tiene dos acepciones: obligare rem, "atar una cosa", "darla en garantía", y obligare personam, "imponer un deber a una persona". En contraste con obligare, el sustantivo obligatio surge tardíamente, se le encuentra por primera vez en Cicerón. Así las cosas, no era todavía corriente al final de la Republica y es que, como es sabido, la lengua latina era poco propicia a la admisión de nuevos nombres. Con todo, en la época clásica, obligatio fue un termino jurídico bien conocido y lo mismo que obligare usado en relación con cosas y personas (obligatio rei, obligatio personae). Se admitió que el verbo obligo tiene como vínculo derivado la obligatio, pero se discutió sobre la naturaleza material o ideal de esta vinculación. Así Gioffred hace medio siglo defendió el carácter de vínculo ideal de la obligatio frente a la opinión, más extendida entonces, que consideraba existente un vínculo material de sujeción de la persona obligada, se refería prioritaria- mente a las cosas dadas en garantía más que a las personas de los deudores. Se entendió, apoyándose en Plauto que obligari se refería prioritariamente a las cosas dadas en garantía más que a las personas de los deudores. Véase, RODRíGUEZ ENNES, Luis, "La obligatio y sus fuentes", en Revista Internacional de Derecho romano $\mathrm{N}^{\circ} 3,2009$, pp. 90 y ss.

${ }^{5}$ Véase al respecto, AEDo BARRENA, Cristian, "Obligatio: In iure consistunt", en Revista Chilena de Derecho, 2013, vol.40, №. 3, 2013, pp. 954-955.
} 
Pieri, ${ }^{6}$ indica que el sustantivo obligatio es relativamente tardío en la lengua latina (no pudiendo precisarse exactamente la época de aparición), pues salvo el empleo por Cicerón, no figura entre los juristas latinos. En cambio advierte, el verbo "obligare", tenía un antiguo uso general. Especialmente, el verbo "obligari" se empleaba para designar a la persona culpable de un delito, en otros términos, a la sujeción del culpable de dicho delito con su víctima, o bien para referirse a la pena aplicable al responsable.

Así, Cicerón utiliza el verbo obligare en un sentido general, para designar una cosa consagrada a los dioses (religione obligata $)^{7}$, bien para indicar que una cosa ha salido del comercio, al encontrarse sujeta a título de garantía en favor de otro, ${ }^{8}$ entre las personas, pues estas, refiere Pieri, en las obras de Cicerón, pueden estar vinculadas por un beneficio, una liberalidad. Sin embargo, en su sentido propiamente jurídico, reflejaba un vínculo contraído: "[...] en raison de crimes, de peines ou por la verba de la sponsio". ${ }^{9}$ Fue, en este sentido, sinónimo de "nectere", de donde deriva el sustantivo "nexum".

\footnotetext{
${ }^{6}$ PIERI, Geoges, "Obligation", en Archives de Philosophie du Droit. Vocabulaire fundamental du droit, tomo 35, 1990, pp. 222-224.

${ }^{7}$ En este sentido lo emplea Cicerón, por ejemplo, en De Legibus, Lib. I, XXIII, (58): "Sed $<u t>$ in urbe sepeliri lex vetat, sic decretum a pontificum collegio, non esse ius in loco publico fieri sepulcrum. Nostis extra portam Collinam aedem Honoris. Aram in eo loco fuisse memoriae proditum est. Ad eam cum lamina esset inventa, et in ea scrip- tum <lamina> 'Honoris', ea causa fuit <ut> aedis haec dedicare<tur>. Sed quom multa in eo loco sepulcra fuissent, exarata sunt. Statuit enim collegium locum publicum non potuisse privata religione obligari".

${ }^{8}$ Pieri, cita el pasaje 2, 5, 10 de Catilina de Cicerón, que, en efecto, se refiere al agotamiento de las garantías patrimoniales de los acusados, en términos eufemísticos: "Patrimonia sua profuderunt, fortunas suas obligaverunt; res eos iam pridem deseruit, fides nuper deficere coepit; eadem tamen illa, quae erat in abundantia, lubido perma- net", véase PIERI, Ob. Cit., p. 222.

${ }^{9}$ PIERI, Ob. Cit., pp. 222-223.
} 
En cuanto al sustantivo, este representará un proceso de abstracción del término vínculo, traducido en el acto de ligar y atar, es decir, reflejaba el acto de ligar a dos sujetos en virtud de formas específicas. Así, por ejemplo, "obligatio" no designaba la obligación del mandatario, sino el acto mismo que vinculaba. ${ }^{10}$ De este modo, el origen de la "obligatio" (en particular, del verbo que le da origen), se conecta y, más aún se confunde, con sus causas.

La obligación representa en un estadio primitivo, tanto aquello que da origen al vínculo, como el vínculo mismo. Como indica Cannata, ${ }^{11}$ el concepto de "obligatio", en el lenguaje de los juristas romanos, significaba tanto relación obligatoria, como acto y efecto obligatorio. Y, todavía más, como ha explicado Purpura, el vínculo personal que suponía la "obligatio" y la apropiación del cuerpo por parte del deudor, obedecería a la antigua analogía entre la obligación y el dominio. El acreedor era dueño del cuerpo del deudor, al punto que este podía verse privado de una adecuada sepultura frente a la insatisfacción del acreedor. ${ }^{12}$

Tan profusa es la bibliografía que aborda el origen y desarrollo de la obligatio en el Derecho romano, que ciertamente supera contundentemente el sencillo objeto de nuestra investigación. ${ }^{13}$ No obstante, atenderemos solo muy brevemente a las definiciones que

\footnotetext{
${ }^{10}$ PIERI, Ob. Cit., pp. 225.

${ }^{11}$ CannatA, Carlo Augusto, Corso di Istituzioni di Diritto Romano, Turín, Giappichelli, 2003. p. 13.

${ }_{12}$ PURPURA, Gianfranco, "La «sorte» del debiore oltre la norte: Nihil inter mortem distat et sortem (Ambrogio, de Tobia X, 36-37)", en Iuris Antiqui Historia, t.1. 2009. pp. 245-248.

${ }^{13}$ Las discusiones sobre las definiciones de obligatio son variadas, una excelente síntesis de ellas se encuentra en, LANTELLLA, Lelio: "Note emantiche sulle definizioni di "obligatio", en : AA.VV. Studi in onore di Giuseppe Grosso, Torino, Giappichelli, Vol. IV , 1971, pp. 167 y ss.
} 
este Derecho entregó para el mejor análisis de nuestras reflexiones posteriores.

Existen dos celebres definiciones de obligación en el Derecho romano, una recogida de las Instituciones de Justiniano y la otra irrogada por el jurista Paulo. La primera señala: "obligatio est iuris vinculum, quo necesitate adstringimur alicuius solvendae rei secundum nostris civitatis iura" (I. 3, 13, pr.). Revela esta definición, la idea de que la obligación es un vínculo jurídico en cuya virtud nos vemos forzados a realizar una determinada prestación, según el ordenamiento jurídico a que pertenecemos. ${ }^{14}$

Por su parte Paulo expresa: "obligationum substantia non in eo consistit, ut aliquod corpus nostrum aut servitutem nostram faciat, sed ut alium nobis obstringat ad dandum aliquid vel faciendum vel praestandum" (D. $44,7,3$, pr.). Acá se pone énfasis en la distinción entre la obligatio y el ius corporal. En la obligatio, la satisfacción del interés tutelado viene dada por la actividad del deudor, en cambio, en el derecho real, la satisfacción se produce por la actividad del propio titular. ${ }^{15}$

En ambas definiciones, se distingue una clara concreción de la idea del vinculum iuris, es decir, se coloca al deudor en la necesidad

\footnotetext{
${ }_{15}^{14}$ RodRíGUeZ, Ennes: "La obligatio y sus..." Ob. Cit., , p. 91.

${ }^{15}$ SCHERILLO, ha hecho un esfuerzo por comprobar, en sustancia, la clasicidad de la definición de Paulo, comparándola y cotejándola con un conjunto armónico de textos, entre ellos D. 4, 7 3, 1, del propio Paulo o el de Gayo 4, 3. En relación con el primer pasaje, Scherillo advierte que Paulo emplea una sistemática idéntica a la que utilizará Gayo, en sus instituciones, con lo que se deduce que la voz obligatio revelaba una categoría jurídica conocida por los juristas romanos. En cuanto al pasaje gayano antes citado, Scherillo piensa que la expresión aut servitutem nostram es una abreviación de un texto más largo de Paulo, apareciendo en Gayo nuevamente la contraposición corpora y ius. SCHERILLO, Gaetano: "Le definizioni romane delle obbligazioni", en AA.VV. Studi in onore di Giuseppe Grosso, Torino, Giappichelli, vol. IV , 1971, pp. 103-107.
} 
de satisfacer una prestación, y al acreedor, le dota de un verdadero ius para obtener la satisfacción de dicha prestación. No obstante, como puede apreciarse, solo destacaron el aspecto pasivo de la obligación y no el elemento activo que ella contiene, el del crédito correlativo. No pudieron, como es lógico, prever el desarrollo que le mercantilismo y capitalismo impregnarían. ${ }^{16}$

\section{2.- LA RELACIÓN OBLIGATORIA MODERNA}

Es a consecuencia, de las grandes transformaciones sociales y en general el enorme progreso experimentado por humanidad en los últimos siglos, que la concepción romana de la obligación, ha quedado relegada de su sitial de preeminencia y distanciada de facto con la realidad que regula, por cuanto, no explica ya, todos los posibles estadios en que la necesidad jurídica de las partes suele colocarse. ${ }^{17}$

Tal y como señala la vieja máxima de experiencia, por muy estable que parezca una cosa, esta no puede permanecer incólume ante el descomunal avance de los tiempos. Es así, como Josserand nos ilustra con notable y perspicaz claridad: "El mundo del siglo XX no se adapta a normas que fueron establecidas para el viejo mundo romano, los descubrimientos de la ciencia, el desenvolvimiento de la

\footnotetext{
${ }^{16}$ ABeliuk MANASEVICH, Ob. Cit., p. 25.

17 Según la idea predominante, las codificaciones fueron hijas de los ideales de la burguesía decimonónica, que introdujo el liberalismo económico y la economía capitalista. Sobre esta cuestión véase TOMAS Y VALIENTE, Francisco, "La Codificación. De utopía a técnica vulgarizada", en Luis Michelena Elissalt y José Melena L. (Dir.), Universidad del País Vasco, Vitoria-Gasteiz, 1985, pág., 1485.; En el mismo sentido; RocA GuILLAMON, Juan, "Codificación y crisis del Derecho civil", en AA.VV. Centenario del Código Civil (18891999), Editorial Centro de Estudios Ramón Areces, Madrid, 1990, t. II, pp. 1760-1763, enfatizando el carácter individualista del pensamiento burgués.
} 
instrucción, la concentración de los capitales, los progresos de la locomoción, la multiplicación de las transacciones civiles $y$ comerciales, así como su consiguiente: rapidez, el desenvolvimiento de las prerrogativas del Estado y el debilitamiento de la familia exigen una reforma, que ya se ha iniciado, de la antigua teoría de las obligaciones que se encuentra amenazada hasta en sus cimientos $y$ que debe, si no desaparecer, al menos evolucionar para adaptarse a las necesidades de la hora." 18

El inevitable tránsito de la economía agraria a la industrial, constituirá un motor para la evolución del campo de las obligaciones, como subraya Diez-Picazo: "Los cambios de naturaleza tecnológica y los cambios en la dinámica de la vida económica inciden en el régimen de las obligaciones desde diferentes puntos. El primero afecta a la configuración misma de la teoría general. Toda la teoría general de las obligaciones vigente hasta ahora estaba pensada sobre esquemas de una economía agraria y de una economía de pequeños comerciantes". ${ }^{19}$

Estos notorios cambios económicos, se traducen en un nuevo comercio de bienes de consumo masivo y de servicios técnicos. Provocando, un trastorno entre los emergentes supuestos económicos y las normas jurídicas de antaño, lo que generarla un giro en la misma teoría general de las obligaciones, la cual pasará de una teoría sencilla basada en obligaciones pecuniarias, a una teoría que engloba los criterios nacidos del tráfico en masa y de una economía de servicios.

\footnotetext{
18 Josserand, Cours de Droit Civil... t. Il., Ob. Cit, p. 4.

${ }^{19}$ Diez-PICAZO, Luis, Fundamentos del Derecho civil patrimonial, Thomson-Civitas, Madrid,

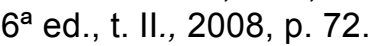


Otra posible causa de evolución, la podemos observar en el fenómeno de estandarización sufrido en materia contractual. Los contratos tipo, sustituyen los esquemas contractuales clásicos por un sistema de pura adhesión. La tecnificación y los procesos de racionalización del trabajo conducen a la automatización de la producción y de la distribución de bienes y de servicios. ${ }^{20}$

A modo de síntesis, nos señala Diez-Picazo: "En la economía moderna se ha producido una inversión de la relación existente entre la producción y el mercado. La gran empresa capitalista, de proporciones mastodóntica, con necesidades de programación a largo plazo, no permite que la producción se adapte al mercado, sino que debe ser al revés. Todos estos datos provocan, una erosión en la teoría tradicional de las obligaciones y la necesidad de construir una nueva teoría general que suponga una ampliación de los anteriores esquemas facticos y que, al mismo tiempo, permita dar trato jurídico nuevo a través de unos principios generales y de unas directrices también nuevas a la problemática económico-social de aquellos hechos que no pueden ser resueltos con los antiguos moldes normativos." ${ }^{21}$

Un importante salto en lo jurídico, fue concebido por el jurista alemán Savigny, quien apropósito de la relación jurídica en general, afirma que la relación jurídica es un todo orgánico en el que determinados sujetos se conecta mutuamente. Solo la eficacia de las normas concebidas orgánicamente puede transformar la realidad

\footnotetext{
20 Diez-PICAZO, Luis, Fundamentos..." Ob. Cit., p. 73.

21 DiEZ-PICAZO, Luis, Fundamentos..." Ob. Cit., p. 73.
} 
social en realidad jurídica. La relación jurídica es un una relación compleja, que representa un todo orgánico que vincula a distintos sujetos como titulares de derechos subjetivos y deberes que se entrelazan y limitan recíprocamente. A partir de Savigny un gran numero de autores comienzan a comentar sus ideas. ${ }^{22}$

En este orden de cosas, con la aparición en el escenario jurídico de la teoría patrimonialista de la obligación, se apuntan valiosos impulsos hacia una concepción más realista de la obligación, con miras a tener en cuenta los diversos elementos implicados en ella. ${ }^{23}$ La obligación se perfila entonces, como una entidad compleja, donde confluyen varios de elementos, transformándose en un verdadero mecanismo integrador de facultades, deberes y cargas. ${ }^{24}$

Bajo este respecto y en contraste a la noción clásica, la obligación se entenderá como una relación obligatoria compleja, es decir, desde una visión orgánica, en que el crédito se presenta como un conjunto complejo de facultades y junto con ellos cargas derivadas de la cooperación que debe prestar en el pago, y, correlativamente la deuda como un conjunto complejo de deberes, junto con derechos y facultades.

\footnotetext{
${ }^{22}$ Véase, al respecto, VILLORO TORANZO, Miguel, Las relaciones jurídicas, editorial Jus, $2^{\mathrm{a}}$ ed., México, 1976.

${ }^{23}$ En contraposición a la teoría personalista de la obligación, esta tesis ya no comporta una responsabilidad que pueda hacerse efectiva en sobre la persona del deudor, para instaurarse en su lugar una responsabilidad de carácter patrimonial, en el sentido de que si el deudor incumple la obligación que ha asumido, el acreedor puede hacer efectivo su derecho de crédito con cargo al patrimonio de su deudor. Esta óptica en su formulación más extrema lleva a la afirmación de que la relación obligatoria no es si no una relación entre patrimonios. Véase, PUIG I FERRIOL et al, Manual de Derecho Civil, Marcial Pons, $3^{a}$ ed. Madrid. vol. II., 1996, p. 23.

${ }^{24}$ CABANillas SÁNCHeZ, Antonio, Las cargas del acreedor en el derecho civil y en el mercantil, Montecorvo S.A., Madrid, 1998, p. 11.
} 
La doctrina no dudó en utilizar metáforas para referirse a esta nueva forma de ver a la relación obligatoria, ${ }^{25}$ organismo (Organismus), estructura (Gefüge), forma (Gestalt), proceso (Prozess), relación marco (Rahmenbeziehung), son sólo algunos de los expedientes lingüísticos empleados para su representación. Asimismo, también se emplea indistintamente las locuciones, relación contractual (Vertragsverhältnis) o relación obligatoria en sentido amplio (Schuldverhältnis im weiteren Sinne) para referirse a ella.

El evidente énfasis puesto por la doctrina, al tratar de encontrar un concepto que identifique y comprenda a esta nueva concepción, radica en la importancia puesta en el carácter unitario y funcional de la misma.

Dentro de esta especial óptica, el clásico viculum iuris, se caracteriza por ser una entidad compleja y espesa, es decir, la obligación se entiende como un organismo, como una estructura o como un proceso. Heinrich Siber, ${ }^{26}$ calificó la obligación como un "organismus", donde convergen una serie de créditos, deberes, tanto principales como accesorios.

\footnotetext{
${ }^{25}$ Una excelente síntesis, sobre este concepto la realiza el profesor Bucher, quien señala que el neologismo "relación obligatoria" debe verse en relación con la figura de la obligación, con respecto a la cual es idéntica en un primer momento, pero de la que luego se diferencia de un modo fundamental debido a las atribuciones posteriores de sentidos distintos. La antigüedad romana fue economizadora en lo que se refiere a la teoría y los conceptos jurídicos. No obstante, ya los clásicos descubrieron el concepto de obligatio como un topos firmemente establecido. Véase, BUCHER, Eugen, "La diversidad de significados de la relación obligatoria en el Código Civil alemán y las tradicionales fuentes extralegales de las obligaciones," en Revista para el Análisis del Derecho, Barcelona, 2006, pp. 7-10.

${ }^{26}$ Véase, SIBER, Heinrich, Sculdrecht, Leipzig, 1931.
} 
Por su parte Karl Larenz, ${ }^{27}$ describió la obligación como una estructura o proceso, por cuanto la obligación es una relación jurídica global, en la cual conviven un conjunto de deberes de prestación y deberes de conducta como también derechos potestativos y situaciones de sujeción.

\section{La relación obligatoria responde a una distribución orgánica de} sus componentes, según la locución de la doctrina que la teorizó incluso parece mejor que el término Gefüge, (estructura)-. En Alemania surge la teorización de la obligación como organismus (Siber, Heinrich Stoll), como relación obligatoria en sentido amplio (Oertmann) o como relación marco (Herholz). ${ }^{28}$

En la práctica la relación obligacional en sentido amplio ${ }^{29}$ se va manifestar como un conjunto compuesto por una multiplicidad de

\footnotetext{
${ }^{27}$ Véase, LARENZ, Karl, Lehrbuch des Schuldrechts, allgemeiner Teil, t.I., München, 1982.; También en, LARENZ, Karl; Derecho de obligaciones, tomo I, trad. Jaime Santos Briz, Revista de Derecho privado, Madrid, 1958, p. 37.

${ }^{28}$ Véase, CASTRONOVO, Carlo, "La relazione come categoría essenziale dell'obbligazione y della responsabilità contrattuale", en Europa e diritto privato, 1., Giuffrè, Milano 2011, pp. 55-76.

${ }^{29}$ Se distingue en el Código Civil alemán o BGB (Bügerliches Gesetzbuch), la noción de Relación obligacional en sentido restringido y amplio. El término técnico "relación obligatoria", se introdujo originariamente en el BGB con el único propósito de usar una expresión alemana en lugar de un extranjerismo como la de obligación. No obstante, la expresión "relación obligatoria" desarrolló durante la elaboración del BGB una dinámica propia y adquirió un segundo sentido, más amplio. Durante la elaboración del BGB estuvo claro desde el principio que el término técnico "obligación" debía sustituirse por el de "relación obligatoria" y que el Libro segundo debía llamarse Recht der Schuldverhältnisse (Derecho de las relaciones obligatorias). Así es como quedó: el término técnico "obligación" ya no existe para el BGB, y del mismo modo ya no habla de pretensiones "obligatorias" ni nada por el estilo. Lo que en otro sitio y al principio también en el Proyecto de Dresde se llamó el ámbito jurídico del "Derecho de obligaciones" se convierte así en el "Derecho de la deuda" (Schuldrecht). La nueva expresión escogida, desarrolla una dinámica propia y crea una nueva cosa, que se yuxtapone a la anterior: la "relación obligatoria" deja de ser simplemente la relación de derecho-deber que surge en el seno de una relación jurídica contractual o de otro tipo, en el sentido primigenio de obligación, y se desarrolla hasta convertirse en lo que hasta entonces se denominaba, de modo ocasional, "relación jurídica" (Rechtsverhältnis) o "relación contractual" (Vertragsverhältnis), es decir, la totalidad de las relaciones jurídicas, incluidas sus circunstancias y efectos accesorios, que surgen entre las partes por la razón referida. En el BGB y para los juristas alemanes, el concepto "relación
} 
pretensiones $\mathrm{u}$ obligaciones (relaciones obligacionales en sentido estricto). Es por ello, que se ha designado como una "ensambladura", como "organismo" o también como "proceso". La relación obligacional no persiste continuadamente estática en el mismo estado, sino que puede cambiar variadamente en el curso del tiempo, la imagen del expresado "organismus" nace, puede crecer, envejecer y finalmente morir. ${ }^{30}$

En la doctrina española, De Castro, resalta tempranamente este carácter orgánico. Indicando que la obligación no puede reducirse solo al crédito o la deuda y que para entenderlas de mejor manera se les ha calificado de organismo (Siber) y caracterizado como estructura y proceso (Larenz). Se ha ido así descubriendo que la relación negocial no consiste solo en exigencias contrapuestas, sino que origina ciertos deberes de cooperación, conforme a las exigencias de la buena fe. ${ }^{31}$

Por su parte, para Diez-Picazo, la relación obligatoria es la total relación jurídica que liga a los sujetos para la realización de una determinada función económica o social en torno a un interés protegido por el ordenamiento jurídico. Luego, conceptualmente la relación obligatoria es, una relación jurídica de unas determinadas características técnicas, que la hacen diferenciarse del resto de las

obligatoria" significa ahora y todavía lo mismo que "obligación" pero junto a ello y por encima de ello significa también algo fundamentalmente distinto. La "relación obligatoria" en el sentido ampliado es una nueva creación que no tiene parangón en ninguna parte. Por doquier fuera de Alemania se contentan con hablar de relaciones de crédito (Forderungsverhältnissen) 0 de obligaciones (Obligationen), sin reunir de un modo conjunto, bajo un concepto comprensivo, las posibles fuentes de las obligaciones (entre las que destacan los contratos y los actos ilícitos). En la escala jerárquica de creciente abstracción y generalización se encuentra el concepto "relación obligatoria", en su sentido nuevo y ampliado, como el superior, esto es, por lo menos un escalón por encima de las ideas de obligación, deuda y crédito y similares. Véase, BUCHER, Ob. Cit., pp.12-19.

${ }_{30}$ Medicus, Dieter, Tratado de las relaciones obligacionales, vol. I, trad., Ángel Martínez Sarrión, Bosch, Barcelona, 1995, vol. I., p. 8.

${ }^{31}$ De Castro y Bravo, Federico, El negocio jurídico, Civitas, Madrid, 1985, p. 39. 
relaciones jurídicas de naturaleza patrimonial y, por supuesto, de todas las demás relaciones jurídicas de Derecho privado. Esta relación obligatoria es, pues, la total relación jurídica que existe, por ejemplo, entre un mandante y un mandatario, entre un comprador y un vendedor, entre un asegurador y un asegurado, en cuanto que toda esta relación constituye una unidad orgánica e institucional. ${ }^{32}$

En este mismo orden de ideas, Blasco Gascó expone: "La mera conexión o correlación entre un crédito y una deuda como situaciones contrapuestas no explica completamente todo el fenómeno obligatorio. En esta concepción no cabe duda que la relación obligatoria se centra en dos polos o posiciones, una activa y otra pasiva; pero significa también la aprehensión de las mismas no como situaciones aisladas o independientes salvo en su correlación, sino como una relación total, global, dirigida a la realización de intereses y fines de naturaleza económica dignos de tutela jurídica. La posición acreedora y la posición deudora no son, entonces, dos posiciones antagónicas o encontradas sino dos situaciones que confluyen en un marco de libertad y de cooperación y colaboración (prestación de servicios y bienes) económica y social". 33

Al respecto, añade Cabanillas Sánchez: "De este carácter de totalidad que se asigna a la relación obligatoria deriva el que todos los deberes, facultades y cargas de los sujetos, el acreedor y el deudor, se encuentren, en cada momento, orgánicamente agrupados en torno a la relación, constituyendo un cauce o instrumento de cooperación

\footnotetext{
${ }^{32}$ DIEZ-PICAZO, Luis, "El contenido de la relación obligacional", en Anuario de Derecho Civil, Madrid, 1964., p. 350.

${ }_{33}$ BLASCO GASCO, Francisco, et al, Derecho Civil, obligaciones y contratos, (coordinador) $\mathrm{M}^{\mathrm{a}}$ R. Valpuesta Fernández, Tirat lo Blanch, $3^{a}$ ed., Valencia, 1998, p. 55.
} 
social. La obligación no puede ser un instrumento de subordinación del deudor al acreedor, sino un instrumento de cooperación del acreedor $y$ del deudor que, junto con sus rasgos productivistas $y$ mercantilistas, muestra la presencia del valor primario de las personas interesadas directa o indirectamente en la relación obligacional." ${ }^{34}$

En conclusión, podemos sostener que la relación jurídica obligatoria actual, posee una indudable naturaleza orgánica o institucional, de la cual, deriva el que todos los derechos, los deberes, las facultades y las titularidades o cargas de los sujetos se encuentren orgánicamente agrupadas en torno a ella. ${ }^{35}$

Este carácter, imprime un nuevo elemento al concepto de obligación, como afirma Castronovo: "Así, la relación obligatoria deja de ser en su esencia deber de prestación y pasa a ser esa relación constante". ${ }^{36}$

\section{3.- ESTRUCTURA DE LA RELACIÓN OBLIGACIONAL}

La relación obligatoria prima facie, aparece cimentada por una estructura tripartita, que se distribuye entre los sujetos de la relación, el objeto o prestación de la misma y el vínculo jurídico que los une.

\footnotetext{
${ }^{34}$ CABANILLAS SÁnCHEZ, Las cargas...., Ob. Cit., pp.12-13.

35 "En la acepción más estricta y técnica del concepto, la última diferencia que individualiza a la obligación dentro del género deber jurídico, consiste en expresar por sí sola la total relación existente entre los sujetos que vincula..." LACRUZ BERDEJO, José. SANCHO Rebullida, Francisco. Luna Serrano, Agustín. Delgado Echeverría, Jesús. Rivera HeRnández, Francisco. Rams Albesa, Joaquín. Elementos de Derecho Civil. Derecho de obligaciones. Vol. 1. Parte general. Teoría general del contrato, Dikynson. Madrid. t. II, 1999, pág. 3.

${ }^{36}$ CASTRONOVo, Carlo, Ob. Cit., pp. 55-76.
} 
Sin embargo, somero análisis, nos parece impreciso, por cuanto, implícito en estas formas, se encuentra una organización mucho mas comprimida y estrecha, forzándonos a reconstruir la estructura precitada, ahora con un carácter binario o bipolar, entre el crédito y la deuda. $^{37}$

En esta concepción, la obligación se presenta como una contraposición entre dos situaciones jurídicas en relación a una conducta o prestación debida: una de poder o activa -la acreedora- y otra de deber o pasiva -la deudora-. En la contraposición o correlación de estas dos posiciones se halla la esencia de la relación jurídica obligatoria, sin que pueda hablarse de una sin tratar a la vez de la otra.

Deuda y poder se presentan, la más de las veces, contrapuestos sin posibilidad alguna de alteridad: "como una relación de guerra entre hombre y hombre, como una perpetua amenaza del acreedor contra el deudor, cuyo momento más significativo está en la sanción conminada contra el incumplido". ${ }^{38}$

\footnotetext{
${ }^{37}$ En la doctrina alemana, esta noción se reconducen a los conceptos de schuld y haftung introducidos a la teoría de las obligaciones por el influjo del Derecho natural contenido en el sistema de pandectas. Este sistema descubren esos elementos (schuld y haftung) implícitos en la obligación romana. El schuld es la deuda, mientras que el haftung es la responsabilidad que surge por el incumplimiento. Según la pandectistica, solo puede existir obligación, (entendida ésta en el sentido del deber jurídico correlativo al derecho de exigencia del acreedor), cuando el deudor incumple, pues solo en ese caso se actualiza el derecho del acreedor de exigir la prestación. Mientras no exista incumplimiento, el deudor solo tiene un deber jurídico que no puede ser reclamado por el acreedor. Este deber jurídico es el schuld. Por ejemplo en un contrato de mutuo a plazo, mientras el plazo no venza, el deudor solo tiene el schuld, y el acreedor no podrá exigirle el pago. Pero si al vencer el plazo el deudor no cumple su prestación en forma espontánea, entonces el acreedor podrá exigir su cumplimiento, dando nacimiento a la figura del haftung, o responsabilidad. Véase, DE LA PEZA, José Luis, De las Obligaciones. editorial McGraw Hiil, México, 1997, p. 2.

${ }^{38}$ ARANGIO-RUIZ, Vincenzo, Responsabilità contrattuale in diritto romano, reimpresión de la $1^{\text {a }}$ ed., Napoli, jovene, 1987, pp. 2 y ss.
} 
Sin embargo, la obligación no se debe valorar tan sólo bajo esta esencial contraposición de poder y deber, sino que también es necesario concebir las diferentes posiciones jurídicas bajo otras perspectivas. Se debe tener en cuenta también el lado activo de la relación, el crédito, y no sólo en función de la legitimación para reclamar el cumplimiento de la obligación, sino, especialmente, para ponderar qué hay en la deuda además del mero deber o sujeción. ${ }^{39}$

Como expusimos, el carácter orgánico y complejo de la relación obligacional moderna, nos impone el mandato de entender, que dentro de una relación obligatoria es posible la existencia de una pluralidad de vínculos jurídicos. ${ }^{40}$ Contiene esta afirmación, la idea que el vínculo jurídico y relación obligatoria son conceptos completamente diferentes. En este estado de cosas, el vinculum iuris, es solo una simple correlación habida entre un crédito y una deuda como situaciones jurídicas coincidentes.

El contenido de esta correlación establecida en la relación obligacional compleja, es un concepto en si novedoso, y antagónico a la antigua noción generalizada de que el crédito es un derecho subjetivo y que la deuda es un deber jurídico. Bajo este contexto, tales afirmaciones son hoy a lo menos incompletas, por cuanto, como se

\footnotetext{
39 SAN MARTín NEIRA, Lilian, "La posición dinámica del acreedor en la relación obligatoria..." en Revista de Derecho Universidad de Concepción, № 225-226, 2009, p.274.

${ }^{40}$ Una pluralidad de vínculos dentro de una única relación obligatoria constituye un fenómeno normal y conocido. Un ejemplo claro será, el de las llamadas obligaciones sinalagmáticas, en donde siempre hay dos vínculos ligados entre sí por un nexo funcional, como en la compraventa, arrendamiento, etc. También puede producirse este tipo de obligaciones sin nexo funcional, como es en el caso del deposito, acá el depositario es deudor de la prestación de guarda y custodia de la cosa, por una parte, y es deudor también de la prestación de restitución de la cosa depositada. Al respecto véase, BLASCO GASCO, et al, Derecho Civil, obligaciones y contratos, (coordinador) $\mathrm{M}^{\mathrm{a}} \mathrm{R}$. Valpuesta Fernández, Tirat lo Blanch, $3^{\mathrm{a}}$ ed., Valencia, 1998, p. 56.
} 
demostrará el crédito y deuda son ante todo una situación jurídicas complejas, donde confluyen facultades, deberes y cargas.

a.- Situación del crédito

Es un hecho bien arraigado y pacífico en la doctrina, que en el crédito existe un autentico y típico derecho subjetivo. ${ }^{41}$ No obstante, tal armonía tienta a más de un análisis.

En este sentido, el crédito no es, solo un derecho subjetivo. Por ende al acreedor no solo se le atribuyen poderes, sino también cargas y deberes. Diez-Picazo, denomina esta circunstancia como "situación acreedora." ${ }^{42}$ Consecuencia de lo anterior, es que definir el derecho de crédito únicamente como derecho a exigir la prestación, resulte indebido y desorientado.

El crédito es ante todo una situación de poder (económico y social) que el ordenamiento jurídico concede a la persona del acreedor para la tutela y logro de su interés. ${ }^{43}$ De Castro ${ }^{44}$ designó esta circunstancia como una situación de poder unitaria y objetiva, que se enfoca en el crédito como un centro de unificación de facultades jurídica.

\footnotetext{
${ }^{41}$ Por ello se entiende una legitimación para actuar autónomamente que confiere un poder unitario sobre una cosa o par exigir de otra persona una conducta determinada y en interés propio. Véase, por todos: PUIG I FERRIOL, Lluis et al., Manual de Derecho civil, Marcial Pons, t. II, $3^{\text {a }}$ ed. Madrid-Barcelona, 2000, p. 59.

${ }^{42}$ DIEZ-PICAZO, Luis, "EI contenido ...." Ob. Cit., pp. 352-361.; Véase también; Estudios de derecho privado, t. I, Madrid, 1972, pp. 372 y ss.; Sistema de Derecho civil, t. II, Madrid, 1983, p.175.

${ }^{43}$ Ibídem, p. 352.

${ }^{44}$ Véase, De Castro y Bravo, Federico, Derecho civil en España, Civitas, Madrid, 1991.
} 
Este conjunto unitario de facultades, esta dirigido en principio, a la satisfacción del interés de su titular, es por eso, que la facultad principal del acreedor es la de exigir al deudor el cumplimiento de la prestación, el incumplimiento del deudor permite al acreedor en su caso contra los bienes del deudor ya sean estos presente o futuros (derecho de prenda general).

No obstante, estas no se agotan ahí, existen una porción de facultades con un objeto diverso al de la exigibilidad, que permiten al acreedor resguardar, disponer, conservar y garantizar su derecho de crédito.

El primer grupo, lo constituyen las facultades de resguardo del normal desenvolvimiento de la relación obligacional, son de esta clases por ejemplo, la facultad de constituir a su deudor en mora mediante la interpelación. También forma parte integrante de este grupo, la circunstancia que el deudor no puede obligar a su acreedor a recibir una cosa distinta a la debida y, tampoco podrá compeler a que reciba parcialmente la prestación.

Un segundo grupo de facultades, las comprende aquellas situaciones en que el acreedor puede disponer jurídicamente de su crédito, un ejemplo de aquello, es la facultad de ceder su crédito a un tercero. Esto tiene sentido, al entender que los derechos de crédito constituyen uno de los elementos que integran el patrimonio de la persona. ${ }^{45}$

\footnotetext{
${ }^{45}$ Esta noción tiene una gran particularidad, ya que el objeto del derecho de crédito, es decir, la prestación, no esta en el patrimonio efectivo aún de su titular y, por tanto, éste y
} 
El tercer conjunto lo conforman, las facultades de tutela o de mera conservación, un ejemplo de ello, lo constituye el acreedor condicional, pues este puede antes de la verificación de la condición, impetrar acciones procedentes para la conservación de su eventual derecho. También se integran en este tipo de facultades, la caducidad en las obligaciones a plazo, la facultad de interrumpir la prescripción, la facultad de renovación de garantías reales cuando estas sean deteriorado o sufrido detrimento.

Por último, existe otro grupo importante de facultades que se concede al acreedor para la garantía e integridad, ya no del crédito mismo, sino de la solvencia y patrimonio del deudor. En este sentido se encuentra la acción paulina, ${ }^{46}$ la acción subrogatoria, ${ }^{47}$ la acción de partición de los bienes que detenta el deudor como comunero, la aceptación de la herencia que el deudor ha repudiado, entre otras.

Este extenso haz de facultades del acreedor, es un justo corolario -creemos- de la idea, que el crédito es algo más que el derecho a exigir la prestación debida, pues, es ante todo como señalamos, un amplio poder económico-social otorgado a una persona para la protección y defensa de un interés que el ordenamiento jurídico considera merecedor de una tutela especial. Sin

sus acreedores dependen de la conducta del deudor para la exigibilidad. Véase, PUIG I FERRIOL, Lluis et al., Ob. Cit. Manual de...., p. 59.

${ }^{46}$ Véase, PASCUAU Liaño, Miguel, "Acción revocatoria o pauliana," en Cuadernos Civitas de Jurisprudencia Civil, № 18, 1088, pp. 1021-1032.; MONTES ÁNGEL, Cristóbal, La vía pauliana, Tecnos, Madrid, 1997; también en "Presupuestos y condiciones de la acción paulina", en Revista de Derecho Privado, № 87, 2003, pp. 295-344.

${ }^{47}$ Véase, GÓMEZ CALERO, Juan, La acción subrogatoria, Tesis doctoral [inédita] universidad de Sevilla, Sevilla, 1958; SIRVENT GARCíA, Jorge, La acción subrogatoria, Colección Monográficas Universidad Carlos III, Madrid, 1998; ALCALDE RODRíGUEZ, Enrique, "La acción subrogatoria", en Revista Chilena de Derecho, Santiago, Vol. 14, № 2-3, 1987, pp. 336-394 
perjuicio de lo categórico de la afirmación anterior, no todo acaba allí, por cuanto, como veremos la complejidad de la relación obligatoria moderna, trae consigo, que a propósito de la situación acreedora, pueda predicarse mucho más que un cúmulo de facultades.

En tal dirección nos advierte Diez-Picazo: "Tendríamos una visión unilateral del fenómeno si concibiéramos el crédito únicamente como un conjunto de facultades armónicamente agrupadas dentro de una situación jurídica unitaria, pues lo cierto es que parece, por lo menos a primera vista, que la ley no se limita a conceder facultades, sino que impone al acreedor determinados deberes y determinadas cargas, al mismo tiempo que limita el ejercicio del derecho con limites como el de obrar dentro del marco de la buena fe o dentro de la finalidad económica-social del Derecho." 48

De lo expuesto, entendemos que al acreedor no solo le corresponden derechos, sino también cargas y deberes. Dichos comportamientos, como veremos, constituyen límites al ejercicio del derecho del acreedor, que pueden derivar entre otras fuentes, de la propia relación obligatoria principal, o de los principios de la buena fe y la proscripción del abuso del derecho.

b.- Cargas y deberes de acreedor

Siguiendo lo dicho precedentemente, parece poco dudoso afirmar, que al acreedor le compete fundamentalmente procurar la

${ }^{48}$ DieZ-PICAZO, Luis, “El contenido ....”, Ob. Cit., p. 357. 
liberación del deudor, facilitando ésta e impidiendo una mayor onerosidad o gravedad para el deudor en el cumplimiento de la prestación. Cabanillas Sánchez, indica al respecto: "El acreedor ha de realizar todo aquello que en su mano esté a fin de que el deudor pueda no solo cumplir, sino también liberarse de la deuda. Este concurso presenta un doble aspecto, positivo y negativo: facilitar el cumplimiento del deudor y no agravar el empeño del deudor en realizar la prestación". ${ }^{49}$

En ese orden, también parece ser despejada la idea, que al acreedor le corresponde colaborar con el deudor, en la medida que esta colaboración sea necesaria, a fin de que la prestación pueda ser cumplida..$^{50}$

La cooperación en sentido técnico se manifiesta cuando para la ejecución de la prestación es necesario el concurso del acreedor, es decir, el deudor no puede efectuar el pago sin la concurrencia del acreedor. A su vez, esta concurrencia puede ser dividida en: concurso preliminar, concurso integrador y concurso sucesivo al cumplimiento. 51

El concurso preliminar, se trata de la actividad requerida a fin de que el deudor pueda llevar a efecto los actos necesarios para el cumplimiento de la obligación. Se trata, por ejemplo, de efectuar las especificaciones necesarias de las cuales se ha reservado derecho, procurar la materia prima, impartir instrucciones, etc. En caso que el

\footnotetext{
${ }^{49}$ Cabanillas SÁnChez, Las cargas...., Ob. Cit., p. 72.

50 Diez-PICAZO, Fundamentos..., t. II., pp. 134 y ss.

${ }^{51}$ Véase, SAN MARTín NeIRA, Lilian, Ob. Cit., 283.
} 
acreedor no ejecute este tipo de actos, el mecanismo de la obligación no se pone en movimiento o, si se ha iniciado, se paraliza. ${ }^{52}$

Por su parte, el concurso integrador, se trata de los actos del acreedor necesarios para la ejecución misma de la prestación como, por ejemplo, cuando, tratándose de obligaciones alternativas, le corresponde la elección de la prestación, cuando debe proceder a la verificación de la obra realizada por el deudor, cuando debe concurrir a la prueba de los vestidos encargado, cuando, el pasajero que debe presentarse en el lugar de partida del medio de transporte, etc. ${ }^{53}$

Por último el concurso sucesivo al cumplimiento, en este caso la cooperación del acreedor no es indispensable para el cumplimiento, en efecto, él puede negarse a cooperar y no por ello el cumplimiento será más o menos perfecto. Aquí la cooperación consiste en otorgar al deudor un medio de prueba idóneo para repeler un ulterior cobro de la misma prestación, por esta razón algunos autores niegan que se trate verdaderamente de cooperación al cumplimiento. ${ }^{54}$

Una revisión rápida y somera de estos comportamientos, importa -necesariamente- darnos cuenta que dichos actos ya no se refieren a facultades o meros derechos subjetivos del acreedor, si no que, al contrario se asemejan o fraternizan más con la idea de imposiciones. Bien, estos comportamientos impuestos al acreedor la doctrina los ha denominado cargas del acreedor.

\footnotetext{
${ }^{52}$ Rescigno, Pietro, Incapacità naturale e adempimento, Edizioni Scientifiche Italiane, 1982, p. 138.

${ }^{53}$ Rescigno, Ob. Cit., p.139.

${ }^{54}$ Rescigno, Ob. Cit., p.140.
} 
Un correcto examen de la naturaleza de estas cargas, nos reclama tener en cuenta el significado y alcance que el Derecho procesal imprime a esta noción, ya que, es un hecho igualmente pacífico por la doctrina, ${ }^{55}$ que el concepto de carga es una institución procedente de tal rama del Derecho.

El concepto de carga procesal, alude a la necesidad de realizar determinados actos para evitar que sobrevengan perjuicios. ${ }^{56}$ Se trata entonces de verdaderos "imperativos del propio interés", ya que, no se trata como veremos, de un deber jurídico propiamente tal, sino de una necesidad o constreñimiento para evitar un perjuicio procesal.

Así por ejemplo, no incumbe a las partes ningún deber de actuación, ni frente al Tribunal, ni frente al adversario, si no, por el contrario las partes son impulsadas a actuar en el proceso por su propio interés, puesto que si permanecen inactivas, corren el cierto peligro de perder su pleito. No se habla entonces de obligación a actuar ni deber de actuación, sino, de carga de actuación.

\footnotetext{
${ }^{55}$ GoldschmidT, James, Prozess als Rechtslage, Berlín, 1925, pp. 81 y ss., Trad. PrietoCastro, Derecho procesal Civil, Barcelona, 1926, pp. 201 y ss; RosenBERG, Leo, Tratado de Derecho procesal I, trad. Romera Vera, Buenos Aires, 1980, p. 90; LIEBMAN, Enrico, Manual de Derecho procesal civil, trad. Sentis Melendo, Buenos Aires, 1980, p. 90; ScoozzAFAVA, "Onere", en Enciclopedia de Diritto, t XXX, Torino, 1980, p. 100; PALERMO, Antonio, Onere, en Novísimo Digesto Italiano, Torino, 1980, t. XI, p. 916; CARNELUTTI, Francesco, Sistema di Diritto processuale civile, t. I, Padova, 1936, p. 55; BETTI, Emilio, Teoría general del negocio jurídico, Trad. A Martin Pérez, Comares, Granada, 2000, p. 92; ALMEIDA Mario, Direito das obligações, Coimbra, 1979, p. 45, PRIETO-CASTRO y FERRÁNDIZ, Leonardo, Tratado de Derecho procesal civil, Pamplona, 1982, t. I, pp. 71-72; ARAgonese, Pedro, Proceso y Derecho procesal, Ed. Aguilar, Madrid, 1960, p.190; DE LA OLIVA, Andrés y FERnÁNDEZ, Miguel Ángel, Lecciones de Derecho procesal, Barcelona, 1984, t. I, p.175.

56 GoLDSCHMIDT, señala que las más importantes cargas procesales son: la de la comparecencia, la de la afirmación y declaración (contestación), la de probar, la de jurar, la de exhibir documentos, la de la caución y anticipo de las costa y la de gestión del proceso. Véase, GOLDSCHMIDT, Ob. Cit, pp. 203 y ss.
} 
Carnelutti, ${ }^{57}$ habla de carga (onere), cuando el ejercicio de una conducta es configurado como presupuesto para obtener una determinada ventaja. Obligación y carga tienen en común el elemento formal, las dos vinculan la voluntad del individuo, pero en la obligación el vínculo es impuesto para tutelar un interés ajeno, mientras que en la carga se protege el interés propio.

En la doctrina italiana ${ }^{58}$ la distinción entre carga y obligación ha adquirido un valor fundamental para comprender la teoría del proceso. Messineo, se refiere a "incombenza", para evitar cualquier tipo de confusión entre carga y obligación. Este autor señala: "En el caso de la carga, por el contrario, ocurre que el sujeto no esta obligado a ninguna cosa, por que a la carga no le corresponde un derecho subjetivo ajeno (pretensión) ni la posibilidad de acción en juicio, pero si el sujeto quiere conseguir un cierto efecto jurídico, tiene la conveniencia (interés) de hacer o no hacer alguna cosa, y si no observa la carga, no consigue aquel determinado efecto útil." 59

Para Betti, ${ }^{60}$ es importante mantener el contraste conceptual entre la obligación, -a la que en el caso de incumplimiento sigue una responsabilidad hacia la otra parte- $y$, la carga -a la que corresponde una autorresponsabilidad en caso de inobservancia-. Por cuanto,

\footnotetext{
${ }^{57}$ CARnelutti, Sistema di ... Ob. Cit. p. 55.

${ }^{58}$ CARnelutTI, Metodología del Diritto, Padova, 1939, p. 97.; Michelı, Antonio, Curso de Derecho procesal, trad. Sentís Melendo, Buenos Aires, 1970, t. I., pp. 264 y ss.; CAlAmAndReI, Piero, Instituciones del Derecho procesal según el nuevo Código, Trad. Sentís Melendo, Buenos Aires, 1986, t. I., pp. 415-416.; DI STEFANO, "Onere", en Enciclopedia del Diritto, Milano, 1980, t. XXX, pp.114 y ss.; PALERMO, Antonio, Onere, en Novísimo... Ob. Cit. 918 y ss.; BETTI, Emilio, Diritto processuale civile italiano, Roma, 1963, pp. 57 y ss.

${ }^{59}$ Messineo, Francesco, Manual de Derecho Civil y .... Ob. Cit., pp. 202-203.

${ }^{60}$ BETTI, Teoría general del negocio...Ob. Cit, p.92.
} 
dicha oposición es necesaria para no confundir las consecuencias jurídicas de ambos conceptos.

Un ejemplo de ello, lo constituye el hecho de que una carga, puede ser mirada e interpretada desde diversas ópticas, así puede ser visto desde la perspectiva de aquel a quien le es impuesta, como también desde el punto de vista de la contraparte, o incluso desde el punto de vista de un tercero para el cual es dable pensar, que dicha carga puede eventualmente resultar ventajosa para él.

Respecto de esta especial perspectiva, pareciese en principio protegido con ella también el interés ajeno y no solamente el propio. La anterior reflexión, es engañosa y desacertada por la sencilla razón, de que la parte contraria o el tercero, no pueden exigir directamente la observancia de la carga frente a la inercia o inactividad del gravado con ella, y en caso de observancia de la carga por el gravado, dicha aparente protección del interés ajeno no es más que un reflejo casual del resultado útil del interés propio del gravado. ${ }^{61}$

El concepto de carga, ya perfilado preliminarmente en el marco del Derecho procesal civil, se ha tenido en cuenta en el ámbito del derecho sustantivo con mucho éxito. ${ }^{62-63}$ Pionera ha sido la doctrina alemana, al referirse a este tipo de traslación, en este sentido, ha

\footnotetext{
${ }^{61}$ BETTI, Teoría general del negocio...Ob. Cit, pp. 92 y ss.

${ }^{62}$ CABANILLAS SÁNCHEZ, Las cargas...., Ob. Cit., pp. 22-23.

${ }^{63}$ No obstante, hay autores que afirman que la carga procesal es diversa a la sustantiva, por que en el Derecho sustantivo la ventaja que deriva de su observancia consiste en la adquirió o en la conservación de un derecho, mientras que e el proceso el incumplimiento de la carga da lugar tan solo a la ventaja de crear una situación procesal que contribuye al resultado de una sentencia favorable, sin garantizar, no obstante, que este resultado, en la decisión final, sea conseguido. Véase, por todos, Di Stefano, "Onere"... Ob. Cit, p. 114.
} 
denominado bajo el término "Obliegenheiten" ${ }^{64}$ la noción de carga que tiene el acreedor en la relación obligatoria.

Se utiliza en este ordenamiento, dicha expresión para explicar la existencia de una serie de supuestos de imposición, que son de grado menor a los que derivan de la prestación principal, por cuanto, la inobservancia de estos, solo darán lugar a una sanción atenuada, que no comprenderá ninguna pretensión orientada a un cumplimiento forzoso o encaminada a resarcir algún daño o perjuicio ocasionado.

Esta sanción atenuada, se traduce en general, en el entorpecimiento del derecho que se intenta hacer valer, o en la reducción y/o destrucción de la posición jurídica del gravado. ${ }^{65}$ De lo que se concluye afirmativamente que tales conductas no son exigibles jurídicamente, pero su inobservancia es gravosa, -imperativos del propio interés- ya que, determina una reducción o perdida del derecho.

En la doctrina española, también la noción de la carga del acreedor aparece vinculada desde su inicio al Derecho procesal civil. ${ }^{66}$ De esta manera, en el marco de la teoría general del Derecho, frente al derecho y el deber, entiende Lacruz, que la carga solo es ocasión de la perdida de una posición ventajosa o de una oportunidad de

\footnotetext{
${ }^{64}$ La doctrina alemana, ha designado a las cargas del acreedor con el término "Obliegenheiten", a su vez, tanto la doctrina española como la italiana, suelen traducir el término "Obliegenheiten", como carga. Véase, CABANILLAS SÁNCHEZ, Las cargas...., Ob. Cit., pp. 27.

${ }^{65}$ Ibídem, p. 24.

${ }^{66}$ En este sentido, los autores; PRIETO-CASTRO, Tratado de Derecho procesal ... Ob. Cit. pp. 71-72; Aragonese, Proceso ... Ob. Cit, p. 190; AlcalÁ-Zamora y Castillo, Niceto, "Enseñanzas y sugerencias de algunos procesalistas sudamericanos acerca de la acción", en Estudios de teoría general e historia del proceso, Instituto de investigaciones jurídicas UNAM, México, 1974, t. I., p. 332.; DE LA OlIVA, y FeRnÁNDEZ, Lecciones de ...., Ob. Cit, p.175.
} 
hacer valer el propio derecho ${ }^{67}$ Confirma el anterior criterio, García Valdecasa, que indica que la ley sanciona en muchos casos un determinado comportamiento con la pérdida de una ventaja jurídica u otro efecto desfavorable, sin que por esto imponga al sujeto la obligación de observar la conducta contraria. ${ }^{68}$

De Castro, a propósito del contenido del patrimonio en su fase pasiva, distingue entre deudas y cargas, estas últimas, no son algo debido, ni una obligación que vincule el patrimonio, su atención solo condiciona a evitar un perjuicio o perdida de dicho bien o derecho. ${ }^{69}$

Por su parte, Diez-Picazo, señala que los comportamientos o acciones que pesan sobre el acreedor, son realmente una carga y no auténticos deberes. Explica que no se trata de una conducta debida, que otro pueda exigir, sino de una conducta necesaria sólo como requisito previo o como presupuesto del acto de ejercicio de una facultad. Afirma el mismo autor: "No se trata de un autentico deber, sino de "un tener" que para poder hacer". ${ }^{70}$

Así las cosas, podemos entender las cargas del acreedor, como conductas impuestas a un sujeto, cuya inobservancia no genera una reacción del ordenamiento jurídico en términos de imputabilidad, reprochabilidad y responsabilidad, sino de privación de los efectos

\footnotetext{
${ }^{67}$ LACRUZ BeRdEJo, José Luis, Elementos de Derecho civil, parte general, Bosch, Barcelona, 1984, t. I., vol. 3, p. 96.

68 GaRcía VAlDECASA, Guillermo, Parte general del Derecho civil español, Civitas, Madrid, 1983, p. 253.

${ }^{69}$ De Castro y Bravo, Federico, Temas de Derecho civil, Madrid, 1972, pp.47-48; Derecho civil de España, DE CASTRO Y BRAVo; introducción de Luis Díez-Picazo, Civitas, Madrid, $1^{\text {a }}$ ed., 2008.

${ }^{70}$ DieZ-PICAZO, “El contenido..., p. 358.
} 
favorables que la adopción de dicha conducta le hubiera producido, no se trata, pues, de una situación de sujeción ni obligación.

La carga es un deber libre, un comportamiento al que el sujeto está constreñido para realizar un interés propio, una necesidad para realizar un derecho suyo. Por ello, el cumplimiento de la carga no es exigible, pero su observancia deslegitima al sujeto para reclamar los efectos que se hubieran derivado del cumplimiento de la misma. ${ }^{71}$ Esta nota característica -falta coercibilidad-, en contraposición a los deberes contenidos en la prestación principal (coercibles por antonomasia), devino a que la doctrina los haya denominado "deberes de comportamiento".

Sentencia al efecto Cabanillas Sánchez: "Esta configuración de la carga presupone claramente tanto la libertad como la posibilidad del acreedor de llevar a cabo la conducta en que consiste la carga, y a su vez, implica una limitación del poder jurídico del acreedor, en la medida en que solo puede ejercitar la facultad conectada a la carga si la observa de forma adecuada. Por eso se dice, con razón que la carga no es objeto de una obligación, sino que implica la necesidad de observarla para la realización del propio interés, es decir, en el supuesto de la carga del acreedor, para que éste pueda ejercitar una concreta facultad". 72

Sin perjuicio de lo anotado y dicho, es necesario advertir desde ya, que esta visión es para nosotros, es en sí parcial, ya que, no todas las conductas y comportamientos impuestos al acreedor corresponden

${ }_{71}^{71}$ BLASCO GASCO, et al, Ob. Cit., 58

${ }^{72}$ CABANILLAS SÁNCHEZ, Las cargas...., Ob. Cit., p. 44. 
a cargas -en el concepto anteriormente enunciado-. Por cuanto, como veremos, dentro de la posición acreedora se encontrarían auténticos deberes jurídicos, que generan a su vez vínculos jurídicos exigibles -y por tanto coercibles- con independencia de la prestación principal, como es el caso de los deberes de protección.

c.- Situación de la deuda

Normalmente, la expresión deuda sirve para designar la posición pasiva de la relación obligatoria, puesto que, el sujeto pasivo asume el deber de cumplir una determinada prestación con el fin de satisfacer el interés del acreedor. Esta visión proviene de la tradicional concepción de obligación, ya que, es precisamente aquel deber jurídico el que compele al deudor a cumplir la prestación debida. ${ }^{73}$

En el siglo pasado, la doctrina de origen germánico, llegó a disociar, en el vínculo obligacional, dos elementos, creados cada uno por actos diversos: la deuda (Schuld), es decir, el deber de prestar por parte del deudor (con correlativa facultad del acreedor de exigir la actividad de cumplimiento de aquél, pero atendido a esta simple exigencia y $\sin$ derecho a dirigirse contra el patrimonio); y la responsabilidad (Haftung), o sea, la posibilidad de repetir judicial o extrajudicialmente contra los bienes del obligado u otro garante.

${ }^{73}$ Blasco Gasco, et al, Ob. Cit., 59. 
Lacruz, ${ }^{74}$ opina que tal distinción es inaceptable, para el derecho vigente, en el cual la responsabilidad acompañada a la deuda como la sombra al cuerpo, de modo que donde hay verdadera deuda, en principio, siempre hay responsabilidad del deudor. Señala al efecto Martínez de Aguirre Aldaz, ${ }^{75}$ la doctrina es pacífica al considerar que si bien en periodos históricos anteriores la deuda y la responsabilidad, como fenómenos jurídicos, han podido aparecer y funcionar con independencia, en el Derecho moderno no ocurre así. Deuda y responsabilidad son dos ingredientes institucionales del fenómeno de la obligación, pero no constituyen dos relaciones o dos situaciones jurídicamente autónomas y distintas. ${ }^{76}$

Sin perjuicio de lo expuesto, y relación a la noción moderna de relación obligacional, es que actualmente se ha sostenido que la deuda no es solo un deber jurídico sino una situación más compleja la situación de la deuda-, cuyo contenido está formado por deberes jurídicos que pesan sobre el deudor, pero donde también radican facultades a través de las cuales el ordenamiento jurídico protege los intereses del deudor. ${ }^{77}$

Sin duda, el fundamental y central deber del deudor en la relación obligacional, es el de realizar la prestación o comportamiento que constituye el objeto de la obligación. Esta conducta o

\footnotetext{
${ }^{74}$ LACRUZ, BERDEJO, José Luis, Nociones de Derecho civil patrimonial e introducción al derecho, Dykinson, Madrid, $4^{\mathrm{a}}$ ed., 2004, pp. 204-205.

${ }^{75}$ Martínez de AguirRe Aldaz, et al, Curso de Derecho civil, Colex, Madrid, 2011, Vol. II., pp. $48-51$

${ }^{76}$ Diez-PICAzo, Luis, Fundamentos del Derecho civil patrimonial, Civitas, Madrid, t. II.,1996, pp. 59-62: también en URBANO SALERNO, Marcelo, Obligaciones, régimen jurídico, editorial Universidad, Buenos Aires, 1995, pp. 26-30; LETE DEL RIO, Manuel y LETE ACHIRICA, Javier, Derecho de Obligaciones, Thomson-Aranzadi, Madrid, vol. I., 2005, pp. 44-45.

${ }_{77}$ DIEZ-PICAZO, Fundamentos..., t. II., pp. 125 y ss.; En el mismo sentido: PUIG I FERRIOL, Lluis et al., Ob. Cit. pp. 63-65.,
} 
comportamiento, es lo que se denomina prestación o conducta prestacional y consiste en dar, hacer o no hacer alguna cosa. ${ }^{78}$

La deuda esta caracterizada esencialmente por el deber jurídico específico $^{79}$ y de contenido patrimonial que asume el deudor. Su inejecución, importa una lesión en sentido amplio al interés tutelado, y abre las vías de tutela satisfactiva, resolutoria y, en su caso, resarcitoria que prevé el ordenamiento jurídico. ${ }^{80}$

En concordancia con lo dicho, es posible sostener, que el deber principal del deudor, es el deber de realizar la prestación. Este deber jurídico, se concreta en la adopción de un determinado comportamiento que debe ajustarse a los rasgos descritos en el programa de prestación establecido en el acto de constitución de la relación obligatoria. ${ }^{81}$

No obstante lo anterior, el deudor esta obligado no solo a lo expresamente acordado por el acreedor, sino también a cuanto derive de la ley, la buena fe y los usos del tráfico, (Código civil español art.1258; Código civil francés art. 1135; BGB § 242; Código civil italiano 1175; Código civil chileno art 1546.) Así es pues, que frente a

\footnotetext{
${ }^{78}$ BLASCO Gasco, et al, Ob. Cit., p. 59.

${ }^{79}$ Opina, Diez-Picazo: "La deuda aparece, prima facie considerada, como un deber jurídico, que consiste en realizar a favor de otra persona un determinado comportamiento, que es "la conducta de prestación". En la literatura jurídica, por lo general, no se pone en duda que la deuda hay que situarla dentro de la categoría del deber jurídico. Son minoritarias y desde nuestro punto de vista inadmisibles aquellas posiciones doctrinales, ya examinadas, que niegan la existencia de un autentico deber jurídico del deudor y admiten únicamente la existencia de una responsabilidad entendida como situación de sujeción o como necesidad de soportar los actos de ejercicio del poder de los acreedores sobre el patrimonio del deudor o los actos realizados por los órganos del Estado en beneficio del acreedor. La responsabilidad es lógicamente un "posterius" que supone la preexistencia de un deber." Véase, DiEZ-PICAZO, Fundamentos..., t. II., p. 141.

${ }^{80}$ PIZARRO, Ramón y VALLESPINOS Carlos, Instituciones de Derecho privado; Obligaciones, Hammurabi, Buenos Aires, t. I, 1999, p. 53.

${ }^{81}$ DieZ-PICAZO, Fundamentos..., t. II., pp.141-142
} 
este deber principal de prestación, aparecen otros deberes que se clasifican como de conducta, accesorios o secundarios, por cuanto, la característica de estos deberes, es integrar y completar el deber principal en orden al integro desarrollo de la relación obligacional. ${ }^{82}$

En consecuencia, es que respecto de ellos, generalmente no quepa el cumplimiento forzado, pero una vez vulnerados, nace la obligación para la contraparte de solicitar la indemnización de los perjuicios causados y a veces la facultad de resolver el contrato. ${ }^{83}$

Estos deberes accesorios, han sido inicialmente enunciados en el escenario jurídico por la doctrina alemana. ${ }^{84}$ Diez-Picazo, ${ }^{85}$ indica que los códigos civiles y los textos legales aluden a estos llamados deberes accesorios al regular concretos tipos contractuales. El principio general de la buena fe y el deber de comportamiento, de acuerdo con los usos del tráfico permiten una generalización de los mismo y, por tanto, un ensanchamiento del deber de prestación.

En relación a la naturaleza, fuente e integración de estos deberes accesorios, cuyas notas pueden predicarse dentro de la relación obligatoria como categoría general tanto para la posición deudora como para la acreedora, nos referiremos más adelante.

d.- Facultades del deudor

\footnotetext{
82 Blasco Gasco, et al, Ob. Cit., p. 60.

${ }^{83}$ PUIG I FERRIOL, Lluis et al., Ob. Cit. p. 64

84 (Nebenpflichten), Véase, LARENZ, Karl, Derecho de obligaciones, Revista de Derecho Privado, Madrid, Trad. Santos Briz, 1958, vol. I, pp. 12-25.

${ }^{85}$ DiEZ-PICAZO, Fundamentos..., t. II., pp. 142-143.
} 
Como señalamos anteriormente, la situación de la deuda no consiste solo en una porción de deberes jurídicos que recaen sobre el sujeto pasivo.

Como señala Diez-Picazo, "el deudor, en cuanto tal deudor es también titular de una serie de facultades, a través de las cuales el ordenamiento jurídico le permite y le facilita la tutela y la defensa de sus intereses. ${ }^{186}$ Pizarro y Vallespinos, ${ }^{87}$ indican que esta visión ha sido impugnada por algunos autores, para quienes, técnicamente no cabría hablar de derechos en sentido estricto. ${ }^{88}$

Más allá de lo mencionado precedentemente, es claro, al menos señalar, que existe una auténtica potestad del deudor, en la facultad que tiene este último de liberarse de la obligación. En su faz positiva, el deudor, tiene el derecho de pagar o cumplir la prestación, es decir, el acreedor, no puede, sin causa justificada, impedir, rehusar u obstaculizar el cumplimiento del deudor y su consiguiente liberación del vínculo obligatorio. ${ }^{89}$

\footnotetext{
${ }^{86}$ Ibídem., p. 146.

${ }^{87}$ PIZARRO, Ramón y VALLESPINOS Carlos, Instituciones... Ob. Cit., p. 54

${ }^{88}$ Conforme a esta perspectiva, se niega que ellas constituyan facultades, por cuanto no hay forma de ponerlas en conexión con el contenido de derecho subjetivo alguno. Se trataría de "meras emanaciones, consecuencias obligadas o mecanismos instrumentales que la ratio iuris y, desde luego, la norma positiva ponen a su disposición para humanizar, favorecer y facilitar el cumplimiento del deber que soporta, al objeto de que tenga lugar de la manera más fácil posible y con la menor carga traumática. Ibídem., pp. 54-56.; También en, MONTES, Cristóbal, "El pago: El papel de la voluntad del acreedor", en Anuario de Derecho Civil, 1986.

${ }^{89}$ Mayores dificultades suscita el problema cuando se trata de una prestación de hacer. No existe en nuestro Derecho positivo un texto legal expreso que contemple la cuestión y que establezca en tal caso la vía de liberación del deudor. No obstante la laguna legal, parece necesario admitir que, frente al acto del acreedor que rehúsa injustificadamente la prestación de hacer que se le ofrece o frente a la inercia del acreedor, el deudor ha de estar en condiciones de hacer patente su voluntad de cumplir, de poner en juego las consecuencias de la "mora creditoris" y finalmente liberarse del vínculo." Véase, DIEZPICAZO, Fundamentos..., t. II., pp. 121-122.
} 
Se añade a lo anterior, la facultad del deudor en poner excepciones, es decir, el deudor posee la facultad de enervar toda pretensión extralimitada o abusiva de su acreedor. El deudor, es también bajo esta perspectiva, titular de determinadas facultades en el desarrollo normal de la relación obligatoria en miras de proteger y tutelar su interés.

Como subraya Diez-Picazo, el Derecho objetivo arbitra, en algunos casos, los medios necesarios para que esta liberación del deudor se lleve a cabo, no obstante la oposición o falta de cooperación del acreedor. Si el deudor de una prestación de dar quiere cumplir, pero el acreedor rechaza sin justa causa la recepción de la prestación, el deudor puede liberarse acudiendo al mecanismo del ofrecimiento formal del pago y de la posterior consignación judicial. ${ }^{90}$

En este sentido, vela bajo este fin el principio general "favor debitoris," que informa todo el Derecho de obligaciones. Según el cual debe entenderse que la obligación, en cuanto limita la libertad del deudor, debe ser considerada en cierta medida como un supuesto excepcional y por ello debe considerarse que quien se obliga, se obliga siempre a lo menos posible. ${ }^{91}$

Sin perjuicio de expuesto, podemos agregar, otro grupo de facultades cuyo titular es también el deudor. Esta facultades derivan de la inobservancia de los deberes de protección, ya que, como

\footnotetext{
${ }^{90}$ PUIG I FERRIOL, Lluis et al., Ob. Cit. p. 66.

91 Diez-PICAZO, Fundamentos..., t. II., Ob. Cit., p.147.
} 
veremos, el objeto principal de estos deberes, es evitar que sean lesionados intereses personales o patrimoniales de la contraparte en la relación obligatoria, especialmente, aquellos referidos a la protección de su vida e integridad física, esta circunstancia, es predicables tanto en el acreedor como en el deudor.

\section{II.- LOS DEBERES SECUNDARIOS DE CONDUCTA.}

Como hemos tenido la ocasión de analizar, el deber de prestación es el deber central y primario del deudor, que se concreta en la adopción de un determinado comportamiento que ha de ajustarse a los rasgos descritos en el programa prestacional configurado en el acto de constitución de la relación obligatoria relaciones obligacionales en sentido estricto-.$^{92}$ Cuando se incumple el deber de prestación surge una responsabilidad frente a la otra parte, que determina a su vez, una serie de consecuencias jurídicas importantes. ${ }^{93}$

Sin perjuicio de lo señalado, el carácter orgánico y complejo de la relación obligacional moderna,${ }^{94}$ afecta la noción de prestación, añadiendo y ampliando su contenido. Ésta deja de concebirse linealmente, es decir, altera notoriamente su conformación típica y técnica.

\footnotetext{
92 Véase, supra nota $N^{\circ} 29$.

93 CABANILlas SÁNCHEZ, Las cargas...., Ob. Cit., pp. 50-52.

${ }^{94}$ Supra, pp. 16 y ss.
} 
Coloca junto a ella, una serie de conductas o deberes que sirven de apoyo a esta última, haciéndola más idónea para el logro del fin al cual se dirige, bajo esta perspectiva pasa a ser concebida como una relación global que alberga en su seno diversos vínculos y situaciones jurídicas.

Desde esta óptica, lo que le da contenido a la relación obligacional y determinará su carácter típico, es la prestación principal, por cuanto toda relación obligatoria recibe su carácter distintivo, (su configuración como contrato de compraventa, de arrendamiento, de mandato) precisamente a través del deber primario de prestación. No obstante, esto no significa que la relación obligatoria se agote con ello. Por el contrario existen deberes que exceden del propio y estricto deber de prestación, estos son los llamados deberes de conducta.

Esta concepción empezó a tomar cuerpo a medida que la doctrina descubría las diversas situaciones jurídicas que se presentan en la relación global que surge de un contrato, realidad ante la cual la concepción lineal se revelaba insuficiente.

Es bajo este esquema, que mediante un método analítico, se van a identificar diversos deberes comprendidos por la relación obligatoria, entre los que a modo de ejemplo se individualizan en: principales y accesorios, típicos y atípicos, deberes accesorios negociados y complementarios, dependientes e independientes, de ejecución y preparación, de cooperación, de aviso y de lealtad entre otros. 
Diez-Picazo, señala que estos deberes integran y ensanchan el contenido de la prestación principal y forman de manera inmediata una parte esencial de ella. ${ }^{95} \mathrm{La}$ utilidad de estos deberes resulta capital, ya que, las partes en una relación obligacional tienen un sin número de posibilidades de beneficiar entre sí pero también de lesionarse, por lo que más allá del plan prestacional, necesitan instrumentos para tutelar dichas circunstancias.

Tales conductas o deberes, dado que tienen como finalidad la realización del interés común perseguido por las partes, son impuestos tanto al acreedor como al deudor de la relación obligatoria, pero es en relación con la actividad de este último, en la que encuentran un mayor desarrollo. Su carácter secundario o complementario se predica de la ejecución o cumplimiento del deber de prestación, que en todo caso, se sigue considerando como la finalidad principal perseguida por las partes.

En términos generales, estos deberes son formas de cooperación o de colaboración al resultado de la prestación y tienden hacer posible la máxima utilidad de ésta, pero se encuentran siempre encuadrados dentro de ella o en conexión con ella. ${ }^{96}$

No obstante, en algunos casos en que estos deberes tienen una finalidad independiente, aunque auxiliar, motivan necesariamente una exigibilidad separada, por lo que, en estos casos conviene hablar no tanto de simples deberes accesorios dentro del marco de una prestación única, sino de prestaciones accesorias. ${ }^{97}$ Lo anterior, se

\footnotetext{
95 DieZ-PICAZO, Fundamentos..., t. II., Ob. Cit., p. 143.

96 CABANILlAs SÁnCHEZ, Las cargas...., Ob. Cit., p. 51.

97 Ibídem., p. 51. También en DIEZ-PICAZO, Fundamentos..., t. II., Ob. Cit., p. 146.
} 
refiere a la situación de los deberes de conducta que aparecen funcionalmente subordinados al deber principal, pero poseen un especial contenido y son distintos a él. ${ }^{98}$

El reconocimiento de este tipo de deberes, le da una conformación más compleja a las relaciones vinculantes de las partes, ello resulta conveniente en la medida en que representan una respuesta a las exigencias de la vida moderna, en la cual la contratación se aparta del ideal de igualdad del siglo XIX y, se caracteriza por la presencia de profesionales especializados, que son productores o distribuidores de bienes o prestadores de servicios, que ordinariamente imponen las condiciones contractuales a los consumidores que con ellos se relacionan, a través de contratos de contenido predispuesto, perfeccionados, por regla general, en virtud de la simple adhesión, terreno éste, que como sabemos, es fértil para el abuso por parte del contratante más fuerte, conocedor y sagaz. ${ }^{99}$

En conclusión, un ejemplo concreto del influjo de la modernidad en el campo del Derecho de obligaciones, fue la creación de la doctrina los deberes de secundarios de conducta. La importancia de esta doctrina, radica para nosotros en el hecho de que resulta una circunstancia coyuntural en la composición del fenómeno de los deberes de protección y sus relaciones con las partes involucradas en el vínculo obligacional.

Ya que, es solo con el impulso que los deberes secundarios de conducta irrogaron a la dogmática jurídica, pueden descifrarse hoy los

\footnotetext{
98 DieZ-PICAZO, Fundamentos..., t. II., Ob. Cit., p. 144.

99 Solarte Rodríguez, Arturo, "La buena fe contractual y los deberes secundarios de conducta," en Revista Universitas, Bogotá, N 108, 2004, p. 305.
} 
elementos básicos y necesarios para concebir los deberes de protección.

\section{1.- ClASES DE DEBERES DE CONDUCTA}

Es preciso advertir desde un principio, que los supuestos de deberes accesorios pueden ser bastantes numerosos, por lo que aventurar una sistematización de estos se hace de suyo complejo, por cuanto, pueden existir tantos deberes como relaciones jurídicas particulares haya entre las partes. ${ }^{100} \mathrm{Sin}$ embargo, tentados en ello, puede sucintamente intentarse, una muy precaria clasificación, en atención a su finalidad.

Así tenemos en dos grandes categorías, por un parte los deberes secundarios de finalidad negativa, como los deberes de protección, cuyo objetivo es impedir que se produzcan lesiones o menoscabos en los intereses personales o patrimoniales de los contratantes.

Y por otra, los deberes secundarios de finalidad positiva, que están destinados a complementar a los deberes de prestación con el fin de que su cumplimiento se realice adecuadamente, ejemplo de los cuales serían los deberes de información, colaboración, consejo o fidelidad, entre los más relevantes.

\footnotetext{
${ }^{100}$ CabAnillas SÁnCheZ, Las cargas...., Ob. Cit., p. 51.
} 
Otra clasificación, atingente a la materia de estudio, la hallamos siguiendo un criterio que consiste en determinar el momento en el que el deudor debe desarrollar la conducta necesaria para que la otra parte de la relación jurídica pueda obtener el resultado útil de la prestación. En este sentido, Betti nos indica, que los deberes secundarios de conducta, que él denomina "obligaciones complementarias", pueden clasificarse en: a) los que son antecedentes a la celebración del contrato; b) los que son concomitantes con el desarrollo de la relación contractual; y c) aquellos que son subsiguientes al cumplimiento de la prestación. ${ }^{101}$

Un factor común en tales clasificaciones, se encuentra en la buena fe. Es este principio rector del ordenamiento jurídico que, ya sea, por mandato del legislador, o, por la concreción de la opinio iuris, resulta ser la causa basal de los deberes secundarios de conducta. ${ }^{102}$

Están explícito e indiscutible este deber básico de conducta humano, que incluso se encuentra en el origen de una eventual contratación. El simple contacto social, aun cuando no se sabe si se va a contratar o no, exige actuar con diligencia, lealtad, corrección y con garantía de la confianza que se pueda tener en el proceder del otro. ${ }^{103}$

La confianza es el soporte de cualquier vínculo obligacional que pueda regir las conductas humanas presentes o futuras. Desde los inicios de las mismas negociaciones de conformidad con el tráfico

${ }^{101}$ BetTI, Emilio, Teoría... Ob. Cit., p. 104.

${ }^{102}$ Sobre el concepto y alcance de buena fe, véase infra, capítulo III.

103 ORDOQUI CASTILA, Gustavo, Buena fe contractual, Colección internacional, Bogotá, 2012, p. 253. 
normal, las partes interactúan y comienzan a cimentar las bases de un futuro acuerdo basado en los actuares leales y correctos, en los cuales, las partes se entregan confiadamente a la concreción de unas expectativas legítimas que se puedan tener.

El deber de lealtad, por su parte, se traduce para la partes en un actuar de cooperación permanente y constante, en este tipo de relación no basta con actuar conforme a derecho o no ejercer conductas fraudulentas, sino por el contrario emprender actuaciones positivas y negativas, con tal de satisfacer las necesidades que le incumben a las partes en unos intereses que en principio se presentan como antagónicos, terminarán siendo estos siempre armónicos. ${ }^{104}$

En un sentido muy general puede decirse, que en todo momento del iter contractual, las partes que intervienen en sus fases están obligadas a conducirse con aquella diligencia y consideración de protección de interés mutuos, y por tanto, esto le permite confiar a estas que según la buena fe, su contraparte actué de la misma forma como ella lo ha venido haciendo y por ende, dicha diligencia debe acompañar no sólo la etapa de formación sino la de ejecución y cumplimiento contractual. ${ }^{105}$

Sin perjuicio de cómo afirmamos precedentemente, respecto a la notoria dificultad de sistematización de los deberes accesorios, intentaremos muy recatadamente referirnos aquellos de mayor uso actualmente en ordenamiento jurídico.

\footnotetext{
104 Monsalve Caballero, Vladimir "La buena fe como fundamento de los deberes precontractuales de conducta", en Revista de Derecho, Barraquilla, 2008, p. 40-41.

${ }^{105}$ Ibídem, p.41.
} 


\section{a.- El deber de información}

Sobre la sublime importancia de la información como necesidad humana, nos ilustra Voyenne: "[...] Tout homme a le droit de savoir. Pour la bonne et simple raison que, sans la connaissance, il ne serait pas un homme. Et, réciproquement, parce que le monde est fait pour êtres connu", por cuanto, como indica el autor de la cita, toda información satisface la necesidad de saber que intrínsecamente cada persona tiene por su condición de tal. ${ }^{106}$

Sin perjuicio de lo precitado y más allá de lo obvio o lo poético en su caso, es menester sostener que muy contrariamente a lo que se pueda pensar, la recepción de los deberes de información como una categoría específica, es un producto de una evolución más o menos tardía en la realidad jurídica y de forma dispersa, ${ }^{107}$ difundida más por dinamismo de los cambios sociales y del comercio, que por un pensamiento jurídico critico subyacente. ${ }^{108}$

Lo anterior, se entiende, toda vez que, en la conciencia colectiva se heredó la creencia romana muy arraigada, de que a cada una de las partes de un contrato le correspondía informarse y adquirir

\footnotetext{
${ }^{106}$ Para Voyenne "[...]Todo hombre tiene el derecho a saber. Por la buena y simple razón que, sin el conocimiento, no seria un hombre. Y, recíprocamente, porque el mundo está hecho para ser conocido", Véase, VOYENNE, Bernard, Le droit à l'information, Aubier Montaigne, París, 1970, p. 11.

${ }^{107}$ La regulación del deber de informar se encuentra dispersa a través de un gran número de normas y figuras jurídicas, que incluyen por ejemplo: El error y el dolo; Los contratos celebrados por menores que se hacen pasar por mayores de edad; La responsabilidad por vicios ocultos; La responsabilidad del vendedor de inmuebles; La responsabilidad por evicción; La nulidad contractual; La publicidad falsa o engañosa. Véase, GómEz CALLE, Esther, Los deberes precontractuales de información, La ley, Madrid, 1994, pp. 27-80.

${ }^{108}$ Monsalve CaballeRo, Ob. Cit., p. 48.
} 
los conocimientos necesarios al momento de celebrar un contrato, ya que, según esta vieja máxima romana "caveta emptor", o bien "emptor debet esse curiosus", cada una de las partes es a la que le incumbe satisfacer sus intereses con el objeto a negociar.

Esta situación se mantuvo casi incólume durante el derecho clásico y moderno. Explica Gómez Calle: "Ese principio de individualismo impera en la época de la codificación decimonónica, si entonces se concebía el contrato como el resultado de un acuerdo de voluntades libres, entre dos partes en igualdad de condiciones, es claro que, desde un punto de vista, la información en la etapa precontractual había de considerarse (en la misma línea que en Roma) como una tarea propia de cada uno de los (futuros y eventuales) contratantes, únicos tutores de sus propios intereses, que se encuentran, además, en contraposición a los del otro. De ahí que en los códigos del XIX el tema de la información precontractual sólo se tocara indirectamente (por ejemplo, desde la perspectiva de los vicios del consentimiento -dolo, error-, o desde la del silenciamiento de ciertos datos en el marco de determinadas relaciones obligatorias) y que no se consagrara un deber general de información, [...]". ${ }^{109}$

No fue, sino hasta que se comenzó a estructurar la responsabilidad precontractual como una doctrina aplicada, por vía de los estudios de la doctrina alemana e italiana, ${ }^{110}$ que se logró dar un reconocimiento paulatino al instituto de la información, lo que a la postre, condujo a introducir en los diferentes marcos legales existentes este deber precontractual de información.

\footnotetext{
109 Gómez Calle, Ob. Cit., p. 12.

${ }^{110}$ Véase, infra pp. 77 y ss.
} 
En los últimos años, debido entre otras cosas, a la aparición de deberes precontractuales de origen legal y a la necesidad de garantizar la buena fe durante los tratos preliminares, se ha despertado un interés por estudiar esta figura con carácter autónomo, es decir, sin necesidad de referirlos a los vicios del consentimiento o a la obligación de saneamiento. ${ }^{111}$

En concordancia a lo manifestado, el deber de información tiene radical relevancia en la etapa precontractual, por cuanto, es ahí, donde los contratantes seleccionan y reúnen los elementos de juicio suficientes para emitir su declaración de voluntad, por lo que, resulta indispensable la cooperación entre estos, en un contexto de corrección y lealtad.

Se une a lo anterior, la circunstancia de que en la actualidad, la regla general en materia de contratos, es la contratación en masa. En este tipo contractual, el productor, distribuidor o profesional, es la parte que tiene un conocimiento especializado del que carece el consumidor, por lo que resulta ciertamente primordial como medio de defensa de este último, un desarrollo dogmático de este instituto, incluso más que en la etapa de ejecución del contrato. ${ }^{112}$

Por último, en este orden de ideas, es también un hecho conocido que la igualdad entre los contratantes en la mayoría de los

\footnotetext{
${ }^{111}$ Monsalve Caballero, Ob. Cit., pp. 48-49

112 En esta etapa el deber de información se encuentra mejor tutelado, toda vez, que el propósito de este deber en este estadio contractual será ahora complementar a los deberes de prestación para que los mismos se puedan cumplir en forma adecuada, oportuna y satisfactoria para el acreedor, por lo que se sigue que cualquier desviación en el mismo se encuentra protegido por el plan obligacional y reconducido directamente a la responsabilidad contractual. Véase, SOLARTE RODRíGUEZ, Ob. Cit., p. 308.
} 
casos, no es más que pura ficción. Cada uno de los negociantes conoce o tiene la posibilidad de conocer más fácilmente que el otro aquellos datos, que afectando al contrato que se pretende celebrar en el futuro, le quedan más próximos, por su conocimiento o influencia, en la materia.

Por tanto, los deberes de información tienen, en sí, una finalidad protectora, que les sirve al propio tiempo de justificación, ya que, pretenden proteger al que se halla en una posición más débil, por su escasa información o por su inexperiencia negocial. ${ }^{113}$

Pues bien, aislada ya su finalidad, es necesario hacernos de una descripción más o menos detallada de este deber, en vías de conciliar una justa prosecución de su análisis. Stiglitz, ${ }^{114}$ al respecto nos señala lo siguiente: "El deber de informar constituye una obligación legal, fundada en una regla accesoria de conducta cuyo contenido consiste en cooperar, desde la etapa de las tratativas, con quien se haya disminuido con relación a la persona que dispone de la información."

Sin perjuicio, de lo útil y sincrético de la definición expuesta, debemos mostrarnos un tanto escépticos en relación a la eficacia y éxito de la misma, lo anterior, dado que no explica la circunstancia de que existan deberes de información de carácter no legal, y por sobre todo, cual sería la expansión de la cooperación debida, dicho esto último en otras palabras, poder determinar sí existe algún limite en

\footnotetext{
${ }^{113}$ Monsalve Caballero, Ob. Cit., p. 52

${ }^{114}$ Cfr., STIGLITZ, Rubén, Contratos civiles y comerciales. Parte general, Abeledo Perrot, Buenos Aires, 1998, p. 165.
} 
relación al deber de información, o por el contrario este es de carácter general o absoluto.

De la Maza, ${ }^{115}$ señala al efecto, que para un mejor entendimiento de este deber de información, es necesario distinguir, entre los deberes típicos y atípicos. Los deberes típicos, son aquellos en que el legislador se ha ocupado expresamente de la ponderación de los intereses, es decir, el legislador ha concretado en la ley la exigencia de la buena fe en lo que se refiere al deber de informar. Un ejemplo claro de este tipo de deberes de información, lo constituye la protección al consumidor en cuanto a la información que el fabricante o proveedor debe entregar al consumidor. ${ }^{116}$

Por su parte, los deberes de información atípicos, son aquellos en que el legislador no ha efectuado una ponderación expresa de los interés en juego, es decir, las exigencias de la buena fe no han sido concretadas a través de la ley, por lo que será tarea del aplicador del derecho hacerlo. Un caso ilustrativo de ello, nos señala el autor, es quien vende un famoso cuadro creyendo que se trataba de una imitación a un comprador que conoce perfectamente la verdadera autoría, en este sentido, ¿debe el comprador informar de ello al vendedor? ${ }^{117}$

\footnotetext{
115 De la MAZA GaZMURI, Iñigo, Los limites del deber precontractual de información, Thomson Reuters Civitas, Navarra, $1^{\text {a }}$ ed., 2010 pp. 29-30.

${ }^{116}$ Entre otros por ejemplo: Informar sobre riesgos a la salud y seguridad; promoción y protección de los intereses económicos del consumidor, acceso a la información adecuada; educación del consumidor. Véase, SANDOVAL LóPEZ, Ricardo, Derecho del consumidor, editorial Jurídica de Chile, Santiago, 2004, pp. 141 y ss.; BARAHONA GONZÁLEZ, Jorge, et al, "La protección de los derechos de los consumidores en Chile" en AA.VV. Cuadernos de extensión jurídica $N^{\circ} 12$, Universidad de Los Andes, 2006, pp. 1-198.

${ }^{117}$ Ibídem, p. 30.
} 
Respecto a los eventuales limites de este deber, afirma De la Maza: "Resulta curioso, a primera vista al menos, que autores que están de acuerdo en que el fundamento de un deber de informar se encuentra en la buena fe mantengan, en cambio, opiniones, a veces, muy diversas acerca de los límites de dicho deber. Así, por ejemplo, García Cantero y Pérez García estiman que la buena fe impone el deber de informar sobre todos aquellos puntos que sean precisos para lograr un consentimiento libre y reflexivo. Una posición bastante diversa parece ser la de García Rubio cuando señala que: [...] en el Derecho español no existe un deber general de informar al otro contratante, sino que, por el contrario, en el ámbito de las relaciones negóciales, cada parte ha de preocuparse de su propio interés $y$, en consecuencia tiene el deber de autoinformarse [...]"118

Concluye el autor, que es posible aceptar, que pueden y deben extraerse de las exigencias de la buena fe, estos deberes de información, no obstante, ello no implica conceder que la buena fe exija a las partes siempre, o en términos muy generales, el deber de suministrar información recíprocamente. Por lo que resulta necesario buscar la forma de concretar las exigencias de la buena fe para salvar una eventual arbitrariedad judicial. En este sentido, es preciso identificar los intereses en juego y la manera en que estos se ponderaran cuando sean contradictorios. ${ }^{119}$

En este orden de ideas, es posible sostener que, el deber de información no detenta en caso alguno categoría de absoluto, por lo que no puede afirmarse que el destinatario esta obligado a estar al

\footnotetext{
118 Ibídem, p. 251.

119 lbídem, p. 374.
} 
tanto e informar, de todo error mediante el uso de la diligencia ordinaria. Pues, no parece contraria a la buena fe in contrahendo la conducta de quien no sabe del error del declarante y, por ende, no le advierte de él, en los mismo casos en que sería lícita la reticencia del destinatario, de haber conocido el error. ${ }^{120}$

b.- El deber de reserva o confidencialidad

En las sociedades actuales, se atribuye una gran importancia a la posesión y tráfico de información, pues ésta, resulta fundamental para el desarrollo -entre otras- de la tecnología, defensa, economía etc., De ello, se deduce que su protección, es de gran interés para el ordenamiento jurídico. En este ámbito, el deber de confidencialidad se presenta como la estructura normativa más idónea, en relación a la protección y tratamiento de la información.

Este deber accesorio, también llamado deber de secreto, tienen lugar bajo el supuesto que en determinados negocios jurídicos la información que se transmite o que se obtiene, no puede divulgarse, publicarse o utilizarse por el destinatario de ella, bajo pena de indemnizar los perjuicios que la violación de dicho deber ocasione. Este deber, se predica tanto para los tratos preliminares como para la celebración, ejecución del contrato e incluso la etapa post-contractual.

\footnotetext{
${ }^{120}$ Véase, BARRIENTOS ZAMORANO, Marcelo, Daños y deberes en las tratativas preliminares de un contrato, Legal Publishing, Santiago, $2^{\mathrm{a}}$ ed., 2010, p. 90.
} 
Cuando se emprenden tratos, es usual que las partes intercambien todo tipo de informaciones, no son pocas las oportunidades en que se hace necesario hacer participe al otro tratante de ciertos secretos. Cualquier negociación formal, tarde o temprano necesitará de un traspaso de ciertas informaciones que pudiera ser consideradas confidenciales por quien las revela. ${ }^{121}$

Todo lo concerniente a la información confidencial con importancia patrimonial y a la que se ha tenido acceso con ocasión de las negociaciones queda cubierto por el deber precontractual de secreto emanado de la buena fe.

Este deber cubre todas las infamaciones secretas a las que se ha tenido acceso con ocasión de los tratos y no se circunscribe sólo a los que se accedió durante ellos, sino incluso a los que se conservan con posterioridad al término de las negociaciones.

La existencia de tal deber, supone que quien participa de unas negociaciones lo hace de buena fe y el resguardo de su otro tratante en la negociaciones viene dado por el designio de evitar que quien participa en las tratativas soporte detrimentos patrimoniales por el hecho de asentir a que la contraparte conozca ciertas informaciones reservadas que poseen relevancia económica. ${ }^{122}$

Desde otra perspectiva, el deber de confidencialidad, se encuentra relacionado intrínsecamente en el ámbito del Derecho público, con el derecho a la intimidad, garantía reconocida

\footnotetext{
${ }^{121}$ Ibídem, p.100.

122 Ibídem, p.100
} 
constitucionalmente por la totalidad de los estados democráticos en la actualidad. ${ }^{123}$

Una segunda óptica de este deber, en este ámbito, lo constituyen aquel grupo de normativas destinadas a la protección de la información empresarial. Bajo este respecto, se pueden destacar, la normativas relacionadas protección intelectual (copyright) y patentes industriales. En ambos supuestos nos encontramos con la noción de secreto y confidencialidad ampara y protegida por el ordenamiento jurídico en distintas faces y estados. ${ }^{124}$

No existe en el derecho español al igual que en el chileno, una única sede de regulación de este deber de confidencialidad, de igual manera tampoco existen, por tanto, soluciones ni sanciones unitarias. bajo esta perspectiva el legislador, ha optado por múltiples formas de protección de la confidencialidad, de diversa índole, como por ejemplo administrativa, laboral, comercial, civil, penal. ${ }^{125}$

En el plano negocial, frente a la evidente inexistencia de una técnica legislativa homogénea, se deberá acudir al principio general de la buena fe y, en su caso, a los instrumentos de Soft Law, -

\footnotetext{
${ }^{123}$ Alvarez GonZÁlez, Norberto, “Intimidad: ¿Derecho de todos o privilegio de algunos?" en Anuario de la Facultad de Derecho, Universidad de Alcalá, 1998, p. 105.; también véase al respecto: CARRIÓN OLMOS, Salvador, "El derecho a la intimidad" en Veinticinco años de aplicación de la Ley Orgánica 1/1982, de 5 de mayo, de protección civil del derecho al honor, a la intimidad personal y familiar y a la propia imagen, (coord.) José Ramón de Verda y Beamonte; Aranzadi, 2007, pp. 93-118; RoMERo PÉREZ, Xiomara, "El alcance del derecho a la intimidad en la sociedad actual", en Revista Derecho del Estado, $N^{\circ} 21,2008$, pp. 209-222.

${ }^{124}$ Véase al respecto, GoLDSTEIN, Paul, El copyright en la sociedad de la información, trad. $M^{a}$ Luisa Llobregat Hurtado, Alicante, 1999; DREIER, Thomas y HUGENHOLTZ, Bernt, Concise European copyright law, Kluwer Law International, 2006.

${ }^{125}$ Caso muy contrario se observa en el derecho anglosajón donde se gozan de verdaderos códigos perfectamente armonizados y unificados sobre la normativa de los "trade secret". Famoso por su gran utilidad es la law of Uniform trade secrets act (UTSA).
} 
predicables a esas circunstancias- para determinar su contenido y posible alcance.

Son un ejemplo de instrumentos de Soft Law predicables al deber de confidencialidad, el proyecto de Pavía y los principios Europeos de los contratos (PECL). Al respecto, el deber de reserva y las consecuencias de su incumplimiento están señalados en el artículo 8 del proyecto de Pavía, a saber: "[...] 1.- Las partes tienen el deber de hacer uso reservado de las informaciones que obtienen de modo confidencial con ocasión del desarrollo de los tratos preliminares. 2.- La parte que no respete este deber estará obligada a reparar el daño sufrido por la otra, y si además ha obtenido una ventaja indebida con la información confidencial, deberá indemnizar a ésta en la medida de su propio enriquecimiento."

Como puede apreciarse, el carácter confidencial resulta de naturaleza esencial en las tratativas, como justa concreción del principio de buena fe en esta materia.

Por su parte, el PECL, en su artículo 2.302 dispone: "[...] Si en el transcurso de las negociaciones una parte comunica a la otra alguna información confidencial, la segunda tiene la obligación de no divulgar dicha información y de no utilizarla para sus propios fines, con independencia de que el contrato llegue a celebrarse o no. El incumplimiento de este deber puede comportar una indemnización por los perjuicios causados y la devolución del beneficio disfrutado por la otra parte." 
Esta regla es ciertamente diversa a la de Pavía, por cuanto, razona bajo la lógica que no existe un deber general de confidencialidad, por ende, el carácter confidencial debe emanar directamente de las declaraciones de la partes o que resulte implícito o tácito de las circunstancias.

Se trata de un criterio excesivamente general, donde el carácter de confidencial dado a una información, supone la prohibición absoluta de utilizarla a su beneficio para su receptor, sin importar si el contrato se llegue a celebrar o no.

c.- El deber de consejo

Aunque con algunos puntos comunes, el deber de consejo es claramente distinto al de información, a lo sumo este último, le suministra solamente un marco referencial.

Este deber se instala, como tal, desde la etapa previa al perfeccionamiento del negocio, oportunidad en que el consejeroinformante, conocedor de la necesidad que a través del contrato se aspira a satisfacer, facilita al acreedor-consumidor la emisión de un consentimiento sustentado en la posibilidad cierta de cumplir sus obligaciones en etapa de ejecución.

De donde se sigue que la inobservancia del deber de consejo y consecuente responsabilidad del consejero-informante, objetivamente se predica de la circunstancia que el co-contratante haya concluido un 
contrato en condiciones desventajosas por haberse omitido suministrarle consejo o porque el mismo haya sido emitido defectuosamente. ${ }^{126}$

Sobre la diferencia del consejo con la información, Gómez Calle nos indica: "El deber de consejo implica un grado de mayor compromiso para el que lo da que la simple y objetiva información, al implicar ya una recomendación subjetiva, tanto desde el punto de vista del emisor como del destinatario, cuyas particulares circunstancias se supone tenidas especialmente en cuenta cuando se le da un consejo, así por ejemplo, es diferente la información que un banco proporciona a un posible cliente sobre las diferentes formas en que puede invertir su dinero (y la rentabilidad, disponibilidad, liquidez, etc., de cada una), del consejo que pueda darle sobre cual sea la más conveniente en su caso concreto. ${ }^{127}$

Así las cosas, el deber de consejo, se diferencia de la información, ya que, importa un "plus" por sobre la misma adicionándole una opinión motivada que puede llegar a constituir una advertencia disuasiva, en atención a las eventuales consecuencias que debería afrontar el destinatario, es decir, el consejo presupone siempre requisitos adicionales o más rigurosos que el de información. De lo anterior, se puede afirmar que no todo obligado a informar lo está también a aconsejar.

\footnotetext{
${ }^{126}$ STIGLITZ, Rubén, "La información precontractual y contractual de información el deber de consejo" en Estudios sobre consumo, Madrid, 1997, p. 50.

${ }^{127}$ Gómez CAlle, Ob. Cit., p. 120.
} 
Se ha sostenido, que la relación profesional puede transformar el deber de informar en un verdadero deber de consejo. ${ }^{128}$ No obstante ello, creemos que para que una obligación de informar se extienda a una de consejo, es preciso que se conjuguen otros factores a tener en cuenta. Así, se requerirá por ejemplo, un consentimiento y aceptación expresa por parte del informante, o que por su parte, exista entre las partes la debida relación estrecha de confianza reciproca. En algunos casos, el objeto de la prestación generará la correspondiente obligación de aconsejar en las partes, por ejemplo, el médico, ingeniero o el arquitecto en el desarrollo de sus obligaciones profesionales.

El deber de consejo, se caracteriza por que el obligado a suministrarlo realiza una valoración de la información "objetiva" a su alcance $y$, con base en un análisis de ventajas y desventajas, advierte o disuade a quien debe recibir el consejo sobre las consecuencias que tendría el tomar una decisión en uno o en otro sentido.

Quien recibe el consejo tiene completa libertad para evaluar los aspectos favorables y los desfavorables de la opinión que se le ha suministrado y adoptar la decisión que mejor le convenga, razón por la cual de los efectos que para él se deriven por la determinación adoptada no se podrá hacer responsable a la persona que haya dado el respectivo consejo. ${ }^{129}$

\footnotetext{
${ }^{128}$ Lo cual dicho con tal generalidad, parece excesivo. Ciertamente, habrá casos en que el profesional sea quien mejor y de forma más rápida, fácil y barata pueda valorar qué producto, de entre los que dispone, se adecua mejor a las necesidades del particular. En casos así, parece defendible afirmar su deber a aconsejar al cliente. Véase, GómEZ CALLE, Ob. Cit., p. 120

${ }^{129}$ Solarte Rodríguez, Ob. Cit., p. 309.
} 
En este orden de ideas, constituyendo el consejo por regla general, una obligación de naturaleza medial, comporta que el acreedor de este, se halla en libertad de apreciarlo, y de evaluar los riesgos lo que, en principio, exime al profesional de responsabilidad por los daños causados por la ejecución de un comportamiento libremente elegido, de lo que se sigue, que la información veraz y oportuna presupone, que el destinatario de la misma, es quien debe reflexionar sobre el alcance de las consecuencias que podría llegar a importar la formalización del contrato. ${ }^{130}$

\section{d.- El deber de protección}

Dentro de los deberes secundarios de conducta o accesorios a la prestación, se encuentra una clase de deber muy particular, denominado deber de protección u obligación de seguridad, hablaremos en lo sucesivo de deberes de protección, no obstante nos referiremos y entendemos por tal a ambas nociones indistintamente.

Sobre estos deberes dedicaremos el próximo capítulo, empero, dejaremos enunciado desde ya, que a diferencia de los demás deberes accesorios el deber de protección tiene un contenido autónomo respecto a la prestación, con tal suerte, que desde la óptica

\footnotetext{
130 Stiglitz, Rubén, Ob. Cit., p. 54.
} 
del deudor, opera con independencia de que la prestación principal se haya cumplido o no. 


\section{Capítulo segundo}

\section{“EL DEBER DE PROTECCIÓN"}

\section{I.- Noción}

Pareciese un justo corolario de lo recorrido hasta aquí, reafirmar la idea que la relación obligacional constituye un verdadero mecanismo integrador de facultades, deberes y cargas.

No obstante, esta sencilla afirmación no tendría tal obviedad, sino fuese por la irrupción en la dogmática jurídica moderna de los denominados deberes de protección u obligación de seguridad. Será este influjo, el que transformará en evidente, lo que tibiamente venía asomándose con los demás deberes secundarios de conducta en el panorama obligacional.

Marina Frost, al respecto nos indica que la expresión deberes de protección (Schutzpfichten) fue acuñada por Heinrich Stoll en 1936, el cual los contrapone los deberes de prestación (Leistungspflichten), encontrando la particularidad de los Schutzpfichten, en que éstos no guardan ninguna relación con el contenido del contrato, especialmente con la prestación, porque ellos deben evitar los daños que amenazan los bienes jurídicos de los interesados en la ejecución del contrato. ${ }^{131}$

\footnotetext{
${ }^{131}$ FROST, Marina, Vorvertragliche und vertragliche Schultzflichten, Dunker \& Humblot,
} Berlín, 1981, p. 13. 
En este orden de ideas, se hará palpable que dentro de la relación obligacional compleja, existen de una pluralidad de vínculos e intereses diversos entre las partes.

En este sentido, Cabanillas Sánchez, quien es el autor que ha estudiado en España con mayor detenimiento estos deberes dentro de la teoría general de las obligaciones, expone: "Los deberes de protección tienen un sentido propio respecto de los restantes deberes que se integran en la relación obligatoria, haciendo que la deuda no pueda concebirse exclusivamente como el deber del deudor de ejecutar la prestación prometida, sino como una situación jurídica compleja -la situación de la deuda- donde confluyen una pluralidad de deberes, e incluso de facultades. Al lado del deber de prestación, que es el deber central y primario del deudor, aparecen deberes accesorios que sirven de apoyo a la prestación del deudor y la hacen idónea para el logro del fin a que se dirige, y deberes de protección, que ponen de manifiesto cómo la relación obligatoria, junto al interés fundamental acreedor a la realización de la prestación (interés de prestación), existe otro interés consistente en que del vínculo no deriven daños para la persona o el patrimonio de cualquiera de las partes de la relación obligatoria (interés de integridad). Se trata de deberes que surgen frente a los peligros derivados del contacto social al que la relación obligatoria debe necesariamente dar lugar. A diferencia de los deberes de accesorios, los deberes de protección tienen un contenido autónomo respecto al deber de prestación, de modo que, desde la perspectiva del deudor, estos deberes operan con independencia de que la prestación principal se haya cumplido."132

\footnotetext{
${ }^{132}$ CABANILLAS SÁNCHEZ, Antonio, "Introducción al estudio de los deberes de protección en el derecho de obligaciones", en Libro homenaje a Luis Rojo Ajura, escritos jurídicosSantander, Cantabria, 2002, p. 175.
} 
Expuesto nuestro parecer, resulta también justo antes de empezar el análisis, dedicar un momento para hacernos de un marco referencial que nos adelante el panorama o nos allane el camino a seguir.

Así, para ilustrar el contexto en el cual se desarrollan los deberes de protección, es preciso realizar una rápida abstracción y fijar nuestra mirada en el sentido más propiamente económico y profano de la relación obligacional, que no es otra cosa, que el intercambio de bienes y servicios.

Bajo esta especial perspectiva, la prestación, aparece claramente orientada hacia el aumento del patrimonio del acreedor. Luego en oposición a ello, los deberes de protección, no están dirigidos al movimiento de los bienes ni al aumento del patrimonio del acreedor, sino a la prevención de peligros, a la protección de las personas, bienes y otros intereses.

El deudor y el acreedor deben organizar su comportamiento de tal manera, que los intereses de la otra parte no se lesionen durante el desarrollo de la relación obligacional. En la relación obligacional compleja, los deberes de protección cautelan el vínculo obligacional, protegiendo a las partes, en su persona o su patrimonio y también protegen a los terceros, que con la obligación tengan un especial contacto. ${ }^{133}$

\footnotetext{
${ }^{133}$ Menezes Cordeiro, Antonio, Tratado de Direito Civil portugués, Vol. II, CoimbraAlmedina, 2009, p. 455.
} 
De la lectura anterior, podemos permitirnos una primera aproximación al deber de protección, entendiendo por tal todos aquellos deberes que recaen sobre el deudor o acreedor de una prestación principal y cuyo objeto consiste en evitar que sean lesionados intereses personales o patrimoniales de la contraparte, especialmente, aquellos referidos a la protección de su vida e integridad física. $^{134-135}$

\section{II.- TEORÍAS SOBRE SU ORIGEN Y NATURALEZA}

Un paso ineludible en el conocimiento de nuestro instituto, lo constituye necesariamente la determinación de su naturaleza. Así, nos abocaremos a identificar cual o cuales son las causas que justifican su tratamiento, como un ente diverso en el universo jurídico al cual se encuentran adscritos.

Para ello, examinaremos desde las distintas ópticas que nos entrega la responsabilidad civil, a fin contar con la mayor cantidad de herramientas útiles, en orden de salvar las dificultades que presentarán el desarrollo de nuestra investigación.

\section{1.- TESIS PRECONTRACTUAL}

\footnotetext{
${ }^{134}$ Véase, en relación al concepto de deber de protección, FRAGA, JORDANO, Francisco, La responsabilidad contractual, Civitas, Madrid, 1987, pp. 141 y ss.

${ }^{135}$ Como señala Pizarro: "En ciertos casos el deudor debe garantizar que el acreedor no sufriera daños, principalmente en su persona pero también en sus bienes". Al respecto, PIZARRo Ramón, VallesPinos, Carlos, Obligaciones, Hammurabi, Buenos Aires, 1999, t. 3, p. 602.
} 
Parte de la doctrina considera como una hipótesis de responsabilidad precontractual la vulneración de un deber de protección. Esto se explica, por cuanto con el inicio de las conversaciones contractuales o tratos preliminares, se asumen estos deberes de protección, en orden a la preservación de los daños en la integridad física o los bienes patrimoniales de la otra parte. ${ }^{136}$

Así, la inobservancia de este deber, devendría en un caso de responsabilidad precontractual dado que aún no se ha perfeccionado contrato alguno.

\section{a.- Antecedentes}

Sin perjuicio de lo anotado precedentemente, la responsabilidad precontractual tiene un comienzo y una justificada presencia mucho antes de que germinará en la dogmática jurídica la teoría de los deberes de protección. En efecto, la doctrina de la responsabilidad precontractual tuvo sus inicios en diversos estudios realizados a finales del siglo XIX y principios del XX por la escuela alemana e italiana. ${ }^{137}$

\footnotetext{
${ }^{136}$ CABANILLAS SÁnCHEZ, Antonio, Los deberes de protección del deudor en el Derecho civil, en el mercantil y en el laboral, Civitas, Madrid, $1^{\text {a }}$ ed., p. 25.

${ }^{137}$ Al respecto ver MEDICUS, Dieter, Zur entdeckungsgeschichte der culpa in contrahendo, festgabe fur MAXKASER, zum 80, Geburtstag, Wien-Koln-Graz, 1986, p. 23.; DölLE, Hans, Dölle, Hans, Außergesetzliche Schuldpflichten, Zges, Staats W, 1943, p.103; LARENZ, Karl, Culpa in contrahendo Verkehrssicherungspflicht und sozialer Kontakt, MDR, 1954, y del mismo autor, Lehrbuch des schuldrechts I. Allgemeiner Teil., 13a ed., München 1982. En la doctrina italiana, FAGGELLA, Gabriele. "Dei periodi precontrattuali e Della loro vera ad esatta costruzione scientifica", in Studi guiridici in onore di Carlo Fadda, Napoli, Vol. III., 1906, p. 269; también en, I periodi precontratuali e la responsabilità precontrattuale, Roma, 1918, p.
} 
Incluso antes de eso, Jhering ${ }^{138}$ ya había colocado en un sitial de importancia el concepto de culpa in contrahendo, la que a la postre se transforma en opinión obligada para los juristas de la época.

En su obra, Jhering analizó el caso de una persona que solicitó el envío de 100 libras de un producto determinado y que, al confundir el signo de libra con el quintal, recibió una cantidad muy superior a la pedida. El contrato era, por tanto, nulo, por adolecer de error esencial, pero ¿quién debía afrontar los gastos de embalaje y expedición generados?

La doctrina tradicional no encontraba respuesta para el problema planteado, pues el vendedor dañado -que habiendo confiado en la validez del contrato, veía defraudados sus intereses. Carecía de acción contractual (el contrato era nulo) y de acción extracontractual (el caso no encajaba en ningún supuesto de la Lex Aquiliade dammo dato). Jhering, concluyó que, dado que había una culpa cometida en el período previo al perfeccionamiento del contrato $y$, puesto que ésta era generadora de un daño, podía denominarse a esta situación como "culpa in contrahendo". ${ }^{139}$

36; ALBERICI, G. Il dovere precontrattuale di buona fede, in Analisi della giurisprudeza, Rass. Dir. Civ. 1982, p. 1901. TESSITORE, T, Buona fede e responsabilità precontrattuale, Milano, 1975.

${ }^{138}$ JHERING, Caspar Rudolf von, Culpa in contrahendo oder Schadenersatz bei nichtigen oder nicht zur Perfection gelangten Vertägen, Jena. 1861, reimpresión Bad HomburgBerlin-Zürich, 1969; También en, De la culpa in contrahendo ou des dommages -interdi dans le conventions nulls ou restées imparfaites. Oeuvres divisies, Trad. por De Meulenaere, tomo II, 1893.

139 JHERING, encontró apoyo para tal afirmación en determinados casos particulares del Corpus luris Civilis, en los que contemplaban la venta de la res extra commercium y de una herencia inexistente, cuando el vendedor no informaba al comprador de la imposibilidad de la enajenación por la existencia del objeto. En estos casos, dado el régimen clásico de la tipicidad de acciones, se consideraba que el contratante perjudicado disponía de una acción contractual, la actio empti, contra quien conocía (o pudo conocer) las circunstancias 
Esta concepción originaria de la culpa in contrahendo, se centró en los casos de nulidad del contrato y los daños derivados de este, señala Asúa González al respecto: "No fue discutida, sin embargo, la necesidad de un principio sobre el que asentar la reparación de los daños causados por haberse confiado en la validez de un contrato nulo. Igualmente, y como aportación definitiva de Jhering, quedó la expresión culpa in contrahendo. Esta que, ya desde el principio, designaba no solo un criterio de imputación sino que englobaba la idea de la antijuridicidad, pronto se utilizará para referirse a la responsabilidad derivada de invalidez de un contrato, [...]"140-141-142

Al iniciarse el siglo $X X$, la responsabilidad precontractual experimentó seguidos cambios, desde una responsabilidad por invalidez contractual a uno mucho más general por actuaciones

\footnotetext{
que imposibilitaban la validez del contrato para reclamarle el id quod interest nihi interest contractum initum non fuisse. En consecuencia, JHERING afirmaba que quien incurría en la culpa (Verschuldung) susceptible de provocar la nulidad del contrato, debí indemnizar a contraparte los daños sufridos, hallándose el fundamento de tal responsabilidad en el propio contrato. Véase, BARRIENTOS ZAMORANO, Marcelo, Daños y deberes en las tratativas preliminares de un contrato, Legal Publishing, Santiago, $2^{\mathrm{a}}$ ed., 2010, pp. 15-16.

${ }_{140}$ AsúA GonZÁLEZ, Clara, La culpa in contrahendo. Tratamiento en el Derecho alemán y presencia en otros ordenamientos, Servicio de publicaciones del la Universidad del País Vasco, Bilbao, 1989, pp. 29-30.

${ }^{141}$ Actualmente la culpa in contrahendo, pude ser entendida de tres formas: (i) Falta de diligencia en la fase in contrahendo: Criterio subjetivo de imputación de responsabilidad. (ii) Conducta antijurídica: incumplimiento imputable de determinados deberes de comportamiento en la preparación del contrato. (iii) El hecho mismo de la sujeción a una obligación de indemnizar por daños causados en esa etapa de preparación, llevándolo ya la propia expresión implícita la idea de responsabilidad. Véase, VALÉs DUQUE, Pablo, La responsabilidad precontractual, Reus, Madrid, 2012, pp. 15-22

${ }^{142}$ La tesis de Jhering tuvo importancia en el hecho de conseguir que los daños ante contractum, no quedaran impunes, obligando a resarcirse contractualmente, apoyándose en la lesión de la confianza que un contratante depositó en el otro. Bajo este respecto, no fue solo una la aportación de Jhering a la dogmática jurídica, sino dos, resarcir los como contractuales los daños que hasta esa época no tenían tal consideración y la otra justificar dicha reparación en el quebrantamiento del affidamento y de la bona fides. Véase, CuAdRAdo PÉReZ, Carlo, Oferta, aceptación y conclusión del contrato, Publicaciones del Real Colegio de España, Bolonia, 2003, pp.69
} 
lesivas en el periodo de formación del contrato. ${ }^{143}$

Esta variación vino a polarizarse en la doctrina, ya de manera definitiva, con la aparición de la teoría Verschulden beim Vertragsschlusse, acuñada por Leonhard en 1910. En este supuesto, se reconoce la existencia de un deber de información en la realización de todos los contratos, cuya inobservancia culpable obliga por ende a una reparación. ${ }^{144-145}$

No obstante lo anterior, y volviendo al supuesto de una responsabilidad originada por la infracción o vulneración de un deber de protección, veremos que estructuralmente se trata de elementos y naturalezas muy diferentes a los contenidos en la culpa in contrahendo o en la Verschulden beim Vertragsschlusse de la época.

b.- Leading case: Linoleumfall

El antecedente sustancial e inmediato de la tesis precontractual de los deberes de protección se encuentra en el denominado caso del Linóleo o Linoleumfall, conocido y resuelto por el Reichsgericht (RG) Tribunal del Imperio alemán en la sentencia del 7 de diciembre de

\footnotetext{
${ }^{143}$ Durante la primera década del siglo $\mathrm{XX}$, y ante supuestos similares a la culpa in contrahendo, la jurisprudencia alemana se negó a reconocer una responsabilidad por comportamientos negligentes en el periodo de conversaciones contractuales, Véase, AsúA GONZÁLEZ, Ob. Cit., p. 40

${ }^{144}$ Ibídem, p. 43.

${ }^{145}$ La admisibilidad de este tipo de responsabilidad la justifica Leonhard históricamente, por su presencia de el Derecho romano y común, bajo las nociones de equidad y analogía. Las normas que de hace referencia el autor, son de naturaleza contractual y por analogía se deben aplicar tanto a la fase de ejecución contractual como al estadio de preparación y perfección del contrato. Véase, Ibídem, p. 43.
} 
1911. ${ }^{146}$

\section{Los hechos que dieron lugar a la referida sentencia, ${ }^{147}$ fueron}

${ }^{146}$ SCHMIDT, Peter Jan, "Sentencias famosas: Alemania. Sobe el caso de los rollos de
linóleo", Revista de Derecho Privado, No 24,2013 pp. 329-334., También en Cfr.,
CABANILLAS SÁNCHEZ, Los deberes de protección del... Ob. Cit., p. 26; También en AsúA
GonZÁLEZ, Ob. Cit., p. 91.
${ }^{147}$ Fallo del 7 de diciembre de 1911. i. S. I. \& Co. (demandado) w. W (demandante), Berlín: De los motivos: (considerandos) "[...] De acuerdo con lo determinado por el Berufungsgericht (juez de instancia), luego de que la demandante ya había hecho algunas compras en el almacén del demandado, se dirigió a la sección de linóleo para comprar un tapete del mismo material, deseo que manifestó al trabajador W., quien allí atendía, y luego escogió de entre los modelos que él le enseñó, el que quería para su tapete. Cuando el trabajador quiso sacar el rollo seleccionado por la demandante, puso un poco de lado otros dos rollos que cayeron golpeando a la mujer y a su hijo que andaban allí cerca y los tiró al suelo. No hubo lugar a la venta del tapete porque la demandante, como lo afirmó, se exaltó mucho como consecuencia de la caída.

El tribunal de instancia, sin yerro jurídico, admite una culpa del trabajador $W$. en el incidente de la demandante, porque sin medida de seguridad alguna puso de lado los rollos que, debido a su escasa dimensión relativa, no tenían una estabilidad suficiente, en vez de haberles dado un soporte lateral o de haberlos apoyado en la pared; todo ello a pesar de que habría podido prever que de conformidad con el hábito del público interesado en una compra, la demandante se habría acercado al lugar de almacenamiento de las mercancías cuya exhibición había solicitado. La posición del tribunal de instancia es sustentada con la simple deducción de que los rollos no se habrían caído si el trabajador los hubiera puesto de lado de manera cauta y ordenada.

La opinión del tribunal de instancia de que el demandado es responsable por la culpa del trabajador W. de acuerdo con el $\S 278$ BGB, no es criticable jurídicamente a pesar de la queja de la revisión y se encuentra en armonía con la jurisprudencia del reconocido tribunal. El trabajador W. había entrado en negociaciones para la venta con la demandante, en representación del demandado (§164 BGB, § 54 BGB). La demandante había solicitado la exhibición de un tapete de linóleo que quería ver y comprar. El trabajador W. había atendido la petición con miras a realizar la venta. La petición de exhibición del tapete y la aceptación de tal solicitud miraban a la celebración de un contrato de compraventa, es decir, tenían un fin contractual. Esto no fue ningún simple suceso de facto, como lo hubiera sido, por ejemplo, un simple acto de cortesía, sino que se dio una relación jurídica preparatoria de la venta entre las partes, que lleva consigo un carácter similar al contractual y que generó obligaciones en el sentido en que durante la exhibición e inspección de las. mercancías surgió el deber, tanto en cabeza del vendedor como del comprador, de observar la diligencia debida para con la salud y el patrimonio de la contraparte.

De fundamentos similares ya han partido los fallos del distinguido senado (el vi Zivilsenat) publicadas en las Decisiones del Reichsgericht en lo Civil [rgz], tomos 65, p. 17, y 66, p. 402, y en la jurisprudencia del Reichsgericht se ha reconocido, en numerosas decisiones, que de un contrato o de una relación jurídica pueden derivarse deberes de cuidado (Sorgfaltspflichten) atinentes a la vida y al patrimonio del oponente (Gegner), que en estricto sentido no tienen que ver con la naturaleza jurídica de la relación, pero sin embargo se derivan necesariamente de su configuración fáctica. Ver, fuera del fallo considerado, las decisiones del Reichsgericht en lo civil [rgz], tomos 55, p. 335, y 73 p. 148; y el Semanarios Jurídicos [Juristische Wochenschrift], 1904, p. 358 n. 10, p. 484 n. 6; Rep. vi.113/06, vi.215/07, vi.17/10.

El demandado se ha servido del trabajador $W$. para el cumplimiento de los deberes señalados frente al comprador y por ello es responsable de la culpa de aquel. Aquí tiene 
los siguientes: La demandante entró en un almacén, donde realizó algunas compras; se dirigió después al lugar donde estaba colocado el linóleo con intención de comprar una alfombra de ese material, comunicando tal intensión al dependiente que la atendió, el cual, al sacar el rollo señalado por la clienta, colocó otros dos aparte que cayeron sobre ella y su hijo produciéndoles heridas. La compra finalmente, no se llegó a realizar. En las dos primeras instancias se consideró probada la culpa del ayudante y se responsabilizó al dueño del almacén, en base al $\S 278$, el RG reconociendo del recurso de revisión, confirmó el resultado al que habían llegado las anteriores instancias. ${ }^{148}$

El fundamento del Tribunal, no fue la existencia de un contrato preparatorio, ${ }^{149}$-como lo venia sosteniendo hasta la fecha- sino la de

\footnotetext{
total aplicación la concepción jurídica del § 278 BGB según la cual quien debe una prestación tiene que llevarla a cabo con el debido cuidado, y de este modo, cuando para tal propósito se sirva de un dependiente, tiene que ser garante de la prestación diligente de este; y que igualmente, aquella persona en relación con la cual tiene que llevarse a cabo la prestación, no puede ser colocada en una situación peor porque su contraparte no la realice por sí misma sino porque la haya conferido a un dependiente. Iría en contra del sentido general del derecho si el propietario de un negocio -con quien el interesado en la compra ha querido celebrar el negocio-, en los casos donde el empleado hiriera al cliente por no ser cauteloso al exhibir o al presentar las mercancías, al darlas a degustar, al probarlas o similares, solo respondiera de acuerdo al precepto del $\S 831$ BGB y no de manera absoluta, esto es, que el herido en caso de éxito de la prueba de descargo (Entlassungsbeweis) fuera remitido al dependiente, las más de las veces carente de recursos económicos. No es necesario ocuparse acto seguido de las explicaciones jurídicamente dudosas del tribunal de instancia de que ya con la entrada de un cliente a un negocio o incluso de un visitante sin un propósito determinado de compra se haya cerrado una relación contractual entre este y el propietario, la cual daría lugar a los tan mencionados deberes de cuidado/protección [...]". Véase, (RGZ) Entscheidungen des Reichsgerichts in Zivilsachen, № 28, 1912, pp. 239-241

${ }^{148}$ AsúA GONZÁLEZ, Ob. Cit., p. 91.

${ }^{149}$ La jurisprudencia alemana de la época sometió aquellos casos en que se producían lesiones tanto físicas como a bienes determinados en el curso de las conversaciones negóciales, a la creación ficta de un contrato preparatorio de garantía de integridad física entre los negociantes. El gran inconveniente de tal solución, era la evidente ficción que presumía necesariamente una voluntad contractual en ambas partes de muy dudosa existencia. Un ejemplo de lo anterior es la Sentencia 13 de diciembre de 1906. En la cual el RG para logara la protección contractual, por lo que respecta a las lesiones físicas sufridas con ocasión del contrato no habiéndose celebrado el mismo, admitió la existencia de un precontrato en virtud del cual se garantizaba la seguridad de la otra parte cuya violación
} 
una relación preparatoria de la compra con carácter similar a la contractual y creadora por tanto, en el vendedor como en el comprador, de un deber de cuidado respecto a la salud y a la propiedad de la otra parte.

Al respecto nos ilustra la profesora Asúa González: "El caso del linóleo no es, desde la perspectiva de sus época, un supuesto de culpa in contrahendo, y no puede serlo por que, como se acaba de ver, ésta se ceñía a supuestos de invalidez contractual en los que se causaban dalos patrimoniales. No podía, por otro lado, analizarse desde el prisma de la Verschulden beim Vertragsschlusse por que además de existir un problema cronológico, tal teoría se refería, en su formulación originaría, solamente a situaciones en las que un contrato valido se había celebrado. Resulta, sin embargo, evidente que se presentan en el supuesto que analizamos una serie de extremos de algún modo precursores de lo que será la posterior configuración de la específica responsabilidad en la formación del contrato: La existencia de responsabilidad en base a criterios contractuales sin haberse celebrado un contrato y sin recurrir tampoco a la ficción de su existencia, que el daño reparado no solo pueda ser primeramente patrimonial sino físico y el que se justifique la contractualidad afirmando la existencia de una relación jurídica preparatoria de la compra con carácter similar a la contractual." 150

Este resultado equitativo, construido por el RG, viene a hacerse cargo de la falla de estructural en lo que respecta al régimen de responsabilidad civil extracontractual alemán. En este contexto, es

desencadenaba los efectos del incumplimiento contractual (aplicación del § 278 del BGB) Cfr., N ${ }^{\circ} 65,1906$, p.17.

${ }^{150}$ AsÚA GONZÁLEZ, Ob. Cit., pp. 93-94 
menester señalar que el régimen de responsabilidad extracontractual se consagra en los $§ \S 823$ y siguientes del BGB. ${ }^{151}$

En este régimen, por regla general no hay lugar, como se verá, a ningún tipo de responsabilidad por daños "puramente patrimoniales", debido a la renuncia temprana del propio legislador alemán ${ }^{152}$ a construir el régimen de la responsabilidad extracontractual sobre la base de una cláusula general que obliga a resarcir todo daño que haya sido ocasionado con dolo o culpa como la del artículo 1382 del Código civil francés.

\section{Así las cosas, solo hay responsabilidad extracontractual}

\footnotetext{
${ }^{151}$ La formula más general es la contenida en el $\S 831$ I, según la cual está obligado a reparar el daño causado quien, concurriendo dolo o negligencia, haya lesionado de forma antijurídica la visa, el cuerpo, la salud, la libertad o cualquier otro derecho ajeno. En su segunda parte, el $§ 823$ establece la misma obligación a cargo de quien en las misma condiciones -culpable y antijurídicamente- haya dañado a otro violado una ley protectora, no estando en este caso tasados los derechos y bienes jurídicamente tutelados. Tampoco lo están en el $\S 826$, donde la obligación de indemnizar se impone a quien daña a otro dolosamente y contraviniendo las buenas costumbres. Al margen de estos receptos, hay otros más específicos donde se regulan los perjuicios causados a un crédito ( $\$ 824)$, los provocados por animales ( $\S \S 836,837$ y 838). La referencia a cualquier otro derecho ajeno, contenida en el $\$ 823$ I, ha sido utilizada para incluir en el ámbito protector de esta disposición otros bienes jurídicos y derechos reales limitados, la posesión, el derecho al ejercicio de una actividad empresarial o los derechos de la personalidad. Cfr. AsúA GONZÁLEZ, Ob. Cit., pp. 36-37.

152 "En la ciencia jurídica del siglo XIX se defendió mayoritariamente un regreso al ámbito más limitado de la responsabilidad aquiliana del Derecho romano y fue este punto de vista que BGB. [...] existe unanimidad en que en ningún caso el BGB bajo la cláusula de "otro derecho" se refiere al patrimonio de la parte lesionada como tal. [...] La posición alemana está basada en el miedo de una responsabilidad "en una cantidad indeterminada, por un tiempo indeterminado a una clase indeterminada": Se tenía la idea de que negar en principio el resarcimiento del daño puramente patrimonial es la única manera efectiva de prevenir una escandalosa variedad de demandas provenientes de una multitud de gente que sofocaría las actividades comerciales y volvería intolerable el diario vivir". Sobre las vías que ha recorrido la doctrina alemana para saldar ese vacío, los juristas alemanes "tratan de identificar ciertos criterios incrementando el rango y la intensidad de los deberes del demandado frente al demandante en determinadas situaciones y así, por vía excepcional, justifican la atribución de la responsabilidad. La protección de la confianza razonable generada en el demandante, sus particulares como criterios útiles. Además, algunas construcciones contractuales bastante forzadas han sido utilizadas para superar las excesivas limitaciones del régimen de responsabilidad extracontractual". Véase, ZIMMERMANN, Reinhard, Law of Obligations. Roman Foundations of the Civilian tradition, Juta \& Co. Ltd., Cuidad del Cabo, 1992, pp. 809 y ss.
} 
cuando un bien jurídico específicamente protegido por la ley resulte lesionado, como el cuerpo humano, la salud o la libertad.

Tal limitación, se tradujo en dos grandes dificultades que la doctrina y jurisprudencia de la época debió afrontar. En primer lugar, no cabe duda de que el daño patrimonial es resarcible si es consecuencia de la lesión a uno de los interés jurídicos previstos por el legislador, pero fuera de esos casos, los daños meramente patrimoniales difícilmente encuentran un fundamento en el régimen aquiliano de responsabilidad. ${ }^{153}$

En este sentido, Asúa González señala: "Tanto en la dicción legal como en su desarrollo posterior se observa una importante ausencia, el patrimonio. Este, como tal, no se halla, en principio, tutelado a no ser que la lesión patrimonial sea una consecuencia ulterior derivada del daño a un derecho o bien jurídico protegido -los enumerados en el $\S 823$ l-. Por esta razón se habla de daños primeramente patrimoniales: por que el patrimonio resulta perjudicado sin la lesión a ninguno de los bienes jurídicos especificados. Sí serán, en cambio indemnizables los perjuicios exclusivamente primeramente- patrimoniales, si se han irrogado vulnerando una ley protectora (\$823 II) o mediando una actuación dolosa (§ 826), pero no aquellos en cuya producción solo ha intervenido negligencia." 154

Así las cosas, para suplir estos vacíos, la jurisprudencia no dudo en extender el régimen de responsabilidad contractual, por medio de la configuración de contratos implícitos de información o de

\footnotetext{
${ }^{153}$ RodRíGUEZ OLmos, Javier, "Deberes de protección 'aun frente a terceros' en la doctrina alemana", Revista de Derecho Privado, № 20, 2011, p. 322.

${ }^{154}$ AsÚA GONZÁLEZ, Ob. Cit., p. 37.
} 
garantía. Construidos a través del recurso de la culpa in contrahendo, que surgida sobre la base del contacto negocial, sigue los principios de la responsabilidad contractual, precisamente para salvar las deficiencias de la responsabilidad aquiliana. ${ }^{155-156}$

La segunda gran dificultad, radica en los estrechos supuestos de responsabilidad por el hecho de terceros (responsabilidad de los auxiliares y dependientes) que contiene el BGB. ${ }^{157}$ Es así, que de conformidad al $\S 831 \mathrm{I}$, el responsable de una actividad o el que se sirve de otro para realizar una función, si bien esta obligado, en principio, a reparar el daño causado por su dependiente o auxiliar, puede sin embargo, exonerarse de tal obligación si demuestra que en la elección (culpa in eligendo) y supervisión (culpa in vigilando) del mismo empleo la diligencia debida. ${ }^{158}$

Esta circunstancia, llevó en la práctica a resultados verdaderamente inequitativos, ${ }^{159}$ ya que, como resulta obvio, la presunción antes señalada -iuris tantum- era de fácil exoneración por parte del empresario, lo que dejaba a costa del auxiliar la total responsabilidad, y consecuencialmente la notoria disminución de la capacidad económica del autor directo a la hora de resarcir los perjuicios ocasionados a la víctima.

\footnotetext{
${ }^{155}$ RodríGUez Olmos, Ob. Cit., p. 324.

156 "Se vislumbra con lo dicho la razón por la que el régimen de responsabilidad extracontractual fue determinante en el desarrollo de la culpa in contrahendo: hubo que buscar un principio que permitiera hallar fundamento indemnizatorio para daños que, estando excluidos del régimen contractual, tampoco encontraban acomodo en los $\$ \S 823$ II y 826. Efectivamente, tanto en los casos plasmados en el BGB, reflejo de las ideas de Jhering (§§ 122, 179 II, 307, 309), como en toda la problemática de los daños sufridos como consecuencia de actuaciones en el periodo de formación del contrato surgida a partir de tales ideas, el perjuicio era primeramente patrimonial y provocado de forma negligente" Cfr., AsÚA GONZÁLEZ, Ob. Cit., p. 37.

${ }_{157}$ SCHMIDT, Ob. Cit., p. 330.

${ }^{158}$ AsÚA GONZÁLEZ, Ob. Cit., p 38.

${ }^{159}$ RodríGuez OlmOS, Ob. Cit., p. 325.
} 
Por su parte el $\S 278$, ya en terreno propiamente contractual, tiene un criterio totalmente inverso al $\S 831$, ya que, establece expresamente que el deudor no puede de ninguna manera exonerarse de la responsabilidad derivada de los daños causados por las personas de las que se ha servido para realizar la prestación.

Por tanto, al igual que en la cuestión de los daños puramente patrimoniales, la jurisprudencia tomó el camino de la responsabilidad contractual, en donde como resulta evidente, la posibilidad de exculpación no existe, para resolver este tipo de casos. ${ }^{160}$

La ilustración anterior, contiene la esencia de la ratio legis del caso del linóleo, pues, más allá de la justificación de índole económica en dirigirse en contra del dueño del negocio por ser este último sustancialmente más solvente, el aporte que realiza el RG en caso en comento, es de una entidad superlativa, ya que, importa un verdadero reconocimiento de una relación jurídica de carácter similar a la contractual, que impone al dueño del negocio determinados deberes de protección a favor de la víctima. ${ }^{161-162}$

Esta sutil innovación y giro de perspectiva jurisprudencial, constituye sin lugar a dudas el hito básico en el entendimiento de los deberes precontractuales, en orden de concebir entre estos no solo al

\footnotetext{
${ }^{160}$ RodríGuez OLmOS, Ob. Cit., p. 325.

161 SCHMIDT, Ob. Cit., p. 331.

162 "La ventaja que la responsabilidad contractual brinda al perjudicado reside principalmente en la severa responsabilidad por los auxiliares a tenor del $\S 278$ en contraposición del § 831. La nueva jurisprudencia tiende a mejorar la situación del perjudicado en el supuesto de falta de responsabilidad contractual, con referencia a la responsabilidad de los auxiliares admitiendo una culpa in contrahendo." Véase, Ennerccerus y Lehmann, Derecho de obligaciones, vol. № 2, trad., Pérez González y Alguer, Barcelona, 1966, p. 1047.
} 
de información y lealtad -ya bien asentados en la época- sino también la existencia de un deber de protección en la integridad física y propiedad de la otra parte. Queda en evidencia entonces, la traslación de las normas aplicables a la relación obligatoria (contrato) al ámbito precontractual, mediante la aplicación del $\S 278$ en lugar de la del $\S$ 831 del BGB, para justificar jurídicamente dicha existencia. ${ }^{163-164}$

\section{c.- Desarrollo dogmático}

La notable creación jurisprudencial anteriormente descrita, ${ }^{165}$ repercutió en dos aspectos claramente identificables. Por una parte vino a descomprimir un complejo escenario que para la administración de justicia alemana de ese entonces significaban este tipo de daños.

Y por otro, puso al descubierto la necesidad de encontrar en la doctrina un fundamento dogmático que justificará dichas reparaciones,

\footnotetext{
163 "Esto significa invocar las flexibles reglas de la responsabilidad contractual para remediar las deficiencias de la responsabilidad extracontractual". MARKESINIS, Basil, The German law of Torts, Oxford, 1990, p. 499.

${ }^{164}$ Es necesario, señalar que existían en ordenamiento jurídico alemán otras razones para preferir la responsabilidad contractual en el caso en comento. Así, por ejemplo, el plazo de prescripción extintiva de la acción de responsabilidad es mayor en sede contractual. También en materia de la carga de la prueba había una ostensible diferencia, mediante la inversión de la carga de la prueba en contra del deudor.

${ }^{165}$ La posición del Reichsgericht (RG) fue seguida y ampliada por su continuador el Bundesgerischtsof (BGH, máximo tribunal de la Republica Federal Alemana). Así, en el caso denominado la cascara o bonda de plátano, en el cual se vierten los hechos relativos a las lesiones sufridas por un cliente de un supermercado que resbaló al pisar una cascara de plátano. En este caso, fue admitida una responsabilidad correspondiente del propietario del negocio no ya por la exhibición de las mercancías sino por la mera entrada al local, Cfr., Sentencia del 26 de septiembre de 1961 BGH, Neue Juristische Wochenschrift. 1962, p. 31. También en este sentido, véase el caso conocido como la hoja de hortaliza, en el cual se estableció la responsabilidad del dueño de un autoservicio, por las lesiones sufridas en el mismo por una niña que acompañaba a su madre en las compras al pisar una hoja de hortaliza, en este caso se incluyo en la esfera de protección de los deberes precontractuales a su hija acompañante. Cfr., Sentencia 28 de enero de 1976 BGH, Entscheidungen des Bundesgerichtshofs in Zivilsachen, $\mathrm{N}^{\circ} 66,1977$, pp. 51 y ss.
} 
toda vez, que los argumentos centrales de la decisión jurisprudencial, esto es, la existencia de deberes precontractuales y la aplicación de las reglas de responsabilidad contractual, se basaban más en imperativos de justicia que en una suficiente argumentación teórica.

Una primera proximidad en este sentido, es construida por el jurista alemán Heinrich Stoll, ${ }^{166}$ quien señaló que los deberes precontractuales, tenían una causa en una relación obligatoria que nacía de las conversaciones contractuales, situando al efecto dicha relación en un negocio jurídico, como es la oferta o la invitación a entrar en negociaciones. Sin perjuicio de ello, hay que tener presente, que ya en el caso del linóleo el RG había tenido en cuenta una especie la relación jurídica preparatoria como fundamento de los deberes precontractuales.

Sobre este particular, Asúa González expone: "La afirmación de la relación obligatoria tuvo un eco mayoritario y ello era lógico, porque se trataba de dar un "prius" dogmáticamente aceptable a lo que se revelaba como indiscutible: la responsabilidad por comportamientos lesivos durante el periodo de formación del contrato que implicaban la violación de deberes precontractual. ${ }^{1167}$

Esta teoría no tuvo el carácter negocial que primitivamente le imprimió Stoll, ya que, ella no permitía explicar convincentemente los llamados casos de los almacenes, ${ }^{168}$ toda vez, que podía ocurrir que un eventual cliente, antes de un mediar cualquier tipo de

\footnotetext{
${ }^{166}$ STOLL, Heinrich, Haftung für das verhalten während der Vertragsverhandlungen, LZ, 1923 , pp. 531 y ss.

${ }^{167}$ AsÚA GONZÁLEZ, Ob. Cit., p 55.

${ }^{168}$ Supra, caso del linóleo, pp. 81 y ss.
} 
manifestación, sufriera un accidente en un negocio.

Sin embargo, más allá de las criticas de este matiz por la doctrina, se impondrá en esta última una reconducción dichos deberes precontractuales al concepto de relación de conversaciones contractuales, que si bien, rechaza la nota negocial, se comenzó a predicar de la misma un genérico carácter legal.

A mayor abundamiento, contrariada la opinión de Stoll que veía como hemos señalado el comienzo de la relación en un negocio jurídico unilateral, la otra alternativa posible era derivarla directamente de la ley. Tradicionalmente se distingue en el Derecho alemán, a la hora de referirse a las relaciones obligatorias, entre las que encuentran su razón de ser en un negocio jurídico y las que de forma directa de la ley.

Sin embargo, al deberse la creación de la responsabilidad precontractual en una laguna legal, malamente puede encontrarse en la ley una previsión general respecto a la relación que entre las partes existe en la etapa precontractual.

A pesar de ello y excluido el origen contractual, solo quedaba el legal para ser atribuido. De este modo se puede hablar de legal, por un lado, porque no queda más remedio, y por otro, entendiendo que se trata de una necesidad que surge de la propia conformación del ordenamiento, y que por su reconocimiento consuetudinario tiene la misma fuerza que si la propia ley así lo previera. ${ }^{169}$

169 AsúA GonZÁLEZ, Ob. Cit., p 58. 
Un segundo estadio en la cuestión, lo constituye la teoría del contacto social (sozialer Kontakt), esta visión pertenece a Dölle. ${ }^{170-171}$ Dado el inconveniente que suponía la producción de un daño sin que se haya iniciado relación preparatoria alguna, como es el caso de los almacenes en donde que da de manifiesto la inexistencia de cualquier tipo de inicio de conversación negocial.

Se empezó a hablar de la expresión contacto social dado que resulta un hecho evidente que las conversaciones que preceden a un contrato nacen o tiene como supuesto común necesariamente un contacto social. ${ }^{172}$

Para producir este contacto bastaría con penetrar en el ámbito del cual otro sea responsable y que ello fuese a lo menos un impulso de una situación negocial futura. Ahora bien, es exigible que la entrada en la esfera jurídica ajena se produzca con un título jurídico, ya sea, el consentimiento, ya sea, una autorización del ordenamiento general, ya que sí el titulo no existe, el contacto no puede dar lugar a deberes obligacionales concretos.

Cabanillas Sánchez, señala: "La doctrina del contacto social está marcadamente orientada por la relevancia de un momento fáctico: el del paso de los individuos de una anónima convivencia con

\footnotetext{
${ }_{170}$ DöLLE, Hans, Außergesetzliche Schuldpflichten, Zges, Staats W, 103, 1943, p. 67 y ss.

171 Al contacto social había aludido anteriormente Haupt, como una posible desencadenantes de las relaciones contractuales de hecho (Überfaktische Vertragsverhältnisse, Leipzig, 1941) Dölle, inicia su exposición partiendo del estudio de Haupt, que establece una serie de concretos deberes que no pueden ser circunscritos a la ley o al acuerdo contractual de los interesados.

${ }^{172}$ Dölle acepta la existencia del deber de protección, previsión y conservación (die SchutzFürsorge - Erhaltungspflichten), en el evento de que una persona en el inicio del contacto social, confía sus bienes vitales a la influencia y con ella la guarda y previsión de otra persona. Ibídem, pp. 67-84
} 
la posibilidad de lesiones ocasionales, que la norma delictual general del "neminem laedere" trataría de prevenir, a situaciones de un más estrecho contacto entre ellos, surgiendo éste cuando alguien, para alcanzar determinado fin, expone sus bienes a la influencia ajena $y$, especialmente, cuando entra en la esfera jurídica dominada por otro."173

A modo de síntesis, la importancia de esta teoría radica en el hecho de que hace posible la idea de la existencia de verdaderos y concretos deberes precontractuales relacionados al cuidado de la persona o el patrimonio, justificándolos en el riesgo que proviene de la especial posibilidad de injerencia en la vida o bienes de la contraparte producido por el contacto social.

Un último matiz en esta cuestión, podemos reducirlo en aquellas teorías que aceptan la relación preparatoria como una relación de confianza.

El primer avance en este aspecto lo constituye la teoría del contacto social intensificado (der gesteigerte soziale Kontakt), que se origina a raíz de las criticas causadas por el contacto negocial. Así, el reconocimiento de una relación de protección surgida de un contacto social más intenso podría ser útil para la solución de las cuestiones relacionadas con la responsabilidad de los productores.

Cuando las personas establecen un contacto especial entre sí con el fin de una relación jurídica negocial, necesariamente

\footnotetext{
${ }^{173}$ CABANILLAs SÁNCHEZ, Antonio, Los deberes de protección del deudor en el Derecho civil, en el mercantil y en el laboral, Civitas, Madrid, 2000, p. 41.
} 
abandonan la coexistencia genérica que solo ofrecía posibilidades ocasionales de colisión (neminem laedere) a un status específico que se caracteriza por la confianza (Vertrauen) que lleva consigo consecuencialmente mayores posibilidades de injerencia en la esfera jurídica delos interesados. ${ }^{174}$

Con el establecimiento fáctico de un contacto social intenso surge una relación similar a la contractual, es decir, como si se tratare de la obligación de una relación jurídica entre las partes en contacto que se ha segregado de la convivencia anónima, en consecuencia se transforman en deberes de protección concretos que se refieren recíprocamente a los interesados. No es la promesa negocial el elemento creador de una relación especial de protección, sino la efectiva apertura de la propia esfera de integridad como reacción de una iniciativa ajena. ${ }^{175}$

El colofón de este grupo de teorías viene a materializarse en la obra de Canaris. ${ }^{176}$ Este, encuadra la relación preparatoria como una relación jurídica sin deber primario de prestación, resultante de la ley y teniendo su fundamento en la confianza.

Esta relación legal de protección que nace del contacto social

\footnotetext{
${ }^{174}$ La individualización provocada por el contacto social y la confianza que se otorga y se exige, permite una distribución de los riesgos personales de forma diferente que en el Derecho delictual. Aquí no se trata de sucesos producidos casualmente, que hacen nacer una relación obligatoria dirigida a la indemnización de daños y perjuicios solo con posterioridad a la causación del daño. Ibídem, Ob. Cit., p. 43

${ }^{175}$ Ibídem, Ob. Cit., pp. 44-45

${ }^{176}$ CANARIS, Claus-Wilhelm, "Das Verlöbnis als gesetzliches Rechtsverhältnis, Ein Beitrag zur Lehre von der Vertrauenshaftung", en Archiv für die zivilistische Praxis, 1965, pp.1 -12; también, Ansprüche wegen positiver Vertragsverletzung und Schutzwirkung für Drite bei nichtigen Verträgen, en Juristenzeitung (JZ), 1965, pp. 476 y ss.
} 
es unitaria, ${ }^{177}$ pues existe antes de la celebración del contrato, durante su ejecución e independientemente de la validez del mismo, los cuales cohabitan con independencia de la relación de prestación.

El carácter legal de la relación de protección, que es independiente de la voluntad de las partes, explica que surjan deberes de protección incluso frente a terceros. Canaris, sitúa la teoría de la relación unitaria legal de protección dentro del sistema de responsabilidad por la confianza, en este sistema se ubican todas las hipótesis de violación de deberes de protección con independencia de la responsabilidad contractual y aquiliana.

En España, la doctrina mayoritaria concuerda con la teoría del contacto social como hecho generador de responsabilidad en los tratos preliminares. Así por ejemplo, Diez-Picazo, ${ }^{178}$ destaca la solidez que presenta las tesis de la existencia de la relación precontractual, nacida del contacto social.

El hecho de ponerse en contacto dos personas a fin de negociar la conclusión de un contrato establece entre ellas una cierta conexión y crea un estado de reciproca confianza que no debe ser defraudado, pues una y otra deben un mínimo de lealtad en los tratos. Por su parte, Alonso Pérez ${ }^{179}$ apropósito de la culpa in contrahendo, señala

\footnotetext{
${ }^{177}$ La teoría unitaria es opuesta a la teoría de la transformación que señala que los deberes precontractuales de protección sufren una mutación y fundamento al pasar a ser contractuales después de la celebración del contrato. Canaris, defiende la teoría unitaria que engloba en un todo estructural los deberes de protección, desligándolos de los efectos ex voluntate producidos por el acuerdo contractual, con la consecuencia de que estos deberes pueden sobrevivir en caso de invalidez del propio contrato. Véase, CABANILLAS SÁNCHEZ, Los deberes de ... Ob. Cit., pp. 51-52.

178 Diez-PICAZO, Fundamentos..., t. I., pp. 275-276.

179 ALONZO PÉREZ, Mariano, "La responsabilidad precontractual," Revista critica de Derecho inmobiliario, 1971, p. 863.
} 
que los actos, conversaciones, contactos que forman la etapa in contrahendo como actividad o proceso que no es puramente fáctico, sino que forman lo que en la técnica germánica se denominan contacto social, instaurado entre las partes a los efectos de preparar el contenido del posible negocio.

Puig Brutau, ${ }^{180}$ observa que, aunque todavía entre los interesados no hay una verdadera relación jurídica antes del perfeccionamiento del contrato es evidente que hay una relación social o un contacto social.

En el mismo sentido añade Cabanillas Sánchez, ${ }^{181}$ define el contacto social como aquel que se establece entre personas que se relacionan en el ámbito jurídico sin llegar a hacerlo mediante un contrato. Los tratos que preceden a la celebración de un contrato constituyen un supuesto de contacto social, el cual genera una situación de confianza, de la que nacen determinados deberes, que encuentran su apoyo en los principios de la buena fe.

A modo de síntesis, expone Asúa González: "Estas bases teóricas, sentadas y consolidadas durante las décadas de los años veinte y treinta, son las que aportan los conceptos fundamentales a los que hoy todavía se recurre. De este modo, la existencia de deberes precontractuales que derivan de una relación obligatoria de carácter legal, surgida de las conversaciones contractuales y cuya vulneración se sanciona según las normas contractuales, ha venido

\footnotetext{
${ }^{180}$ Puig BRUTAU, José, Fundamentos del Derecho civil. Teoría General del contrato, t. II., Bosch, Barcelona, 1978, pp. 226-227.

${ }^{181}$ CABANILLAS SÁNCHEZ, Antonio, "El ámbito de la responsabilidad precontractual o culpa in contrahendo," Revista critica de Derecho inmobiliario, № 68 mayo-junio, 1995, p.753.
} 
siendo, y lo es actualmente, un lugar común en la doctrina y la jurisprudencia, reconociéndose a este tipo de principio el carácter de costumbre jurídica." 182

\section{2.- TESIS CONTRACTUAL}

De lo visto hasta acá, resulta poco dudoso sostener que más allá de los problemas suscitados en la responsabilidad precontractual, los deberes de protección una vez vulnerados generan una especie de distorsión en el campo de la responsabilidad civil, contractualizando daños que si no mediaran dichos deberes serían resarcidos por la responsabilidad aquiliana o quedarían en ciertos casos sin reparación alguna.

Para tal efecto, observáremos la evolución de nuestro objeto de estudio en el ámbito contractual, con miras a determinar si tanto su naturaleza y como su fundamento coincide con el imperio temporal del contrato.

a.- Teoría de las lesiones contractuales positivas

${ }^{182}$ AsúA GonZÁlez, Ob. Cit., p 57. 
De la misma manera que el Derecho delictual, ${ }^{183}$ el Derecho de obligaciones alemán presentó una serie de dificultades y problemáticas. $^{184}$

Así, en materia de incumplimiento de las obligaciones contractuales en el BGB quedaron expresamente reguladas solo dos formas de incumplimiento, esto es, la imposibilidad sobrevenida y la mora debitoris. A mayor abundamiento, en el BGB no existe concepto legal de incumplimiento, ${ }^{185} \mathrm{ni}$ tampoco precepto alguno de carácter general en el que se establezca las consecuencias jurídicas del no desenvolvimiento regular de la relación obligatoria. ${ }^{186}$

Lo anterior, dejaba en el ámbito del vacío legal todas aquellas consecuencias jurídicas que derivaran de la ejecución defectuosa o del incumplimiento de deberes accesorios. Sin perjuicio de lo anterior, la reforma del Derecho de obligaciones alemán del año 2002 vino a modificar radicalmente esta perspectiva.

\footnotetext{
${ }^{183}$ Supra, pp. 84 y ss.

${ }^{184}$ A pesar de haber sido tan fuertemente influenciado por la pandectística, EI BGB no es una obra doctrinaria, ni en su espíritu ni en su enfoque. Sus redactores no se sentían llamados a efectuar definiciones de autoridad de conceptos fundamentales, tales como contrato, declaración de voluntad, daños, causalidad, o ilicitud y, por tanto tampoco pretendían eliminar los debates doctrinales que constituyeran a delimitar su significado. Tampoco pontificaron sobre cuestiones que requerían la elaboración de construcciones jurídicas como por ejemplo ¿qué tipo de acto jurídico es el cumplimiento de una obligación?. El Código no incluyó un buen número de valoraciones y criterios doctrinales que podían darse por sentado. Véase, ZIMMERMANN, Reinhard, El nuevo Derecho de alemán de obligaciones, trad. Esther Arroyo, Boch, Barcelona, 2008. p. 23.

${ }^{185}$ Véase sobre este particular ZIMMERMANN, Law of Obligations.... Ob. Cit. pp. 809 y ss.

${ }^{186}$ Por el contrario, se regulan concretos casos de incumplimientos como la imposibilidad sobrevenida de la prestación, sea objetiva o subjetiva (§§ 275 II, 280 y 235, y la mora (§§ 284 ss. 293 ss.). Además, y para determinados contratos -compraventa (§§ 459 ss.).arrendamiento de cosa ( $\S 537$ ss) y arrendamiento de obra ( $\S 623$ ss.). Véase al respecto, AsúA GonZÁLEZ, Ob. Cit., pp. 33-34.
} 
Haciendo eco de este "gran vacío." ${ }^{187}$ Hermann Staub, ${ }^{188}$ intentó ofrecer un remedio a tales situaciones. Este autor, se percató que de conformidad con el $\S 286$ el deudor debía resarcir al acreedor por el daño derivado de la mora. Incurría entonces en mora, aquel deudor que omite la prestación a la cual esta obligado.

\section{Así, el Derecho de obligaciones protegía eficiente y} suficientemente todos los casos en que el deudor dejaba de hacer lo que debía hacer. No obstante, por el contrario el BGB no contenía una disposición para el caso en que el mismo deudor lesionará el vinculo contractual mediante un hacer positivo, es decir, en el caso de que el

187 No obstante, algunos dudaron de que efectivamente existiera ese "gran vacío", expuesto por Staub. En este sentido, el alejamiento fatigoso pero imparable de la pandectística, explica que los supuestos de hecho limitados e incompletos de las lesiones previstas en el BGB residían en las injustificada generalización de soluciones heredadas de algunas fuentes romanas en las cuales la figura de la imposibilidad estaba limitada a la culpa estipulatoria individual. Como expone Scheider: "Una parte, del $\S 275$ del BGB regulaba la hipótesis de la imposibilidad como fundamento para la liberación del deudor cuando a este último no le era imputable dicha imposibilidad; de otra, el sistema de la responsabilidad del BGB de 1900 se fundamentaba en la idea de una responsabilidad general por culpa que encontraba su norma del dolo y de la culpa. Quien no tenga el debido cuidado actúa negligentemente"). Esta norma, junto con los $\S \S 277$ a 279 (sobre el cuidado llevado a cabo en los asuntos propios, la responsabilidad por la culpa de los dependientes como propia culpa y la responsabilidad en pretensión general de resarcimiento del acreedor en caso de un comportamiento culpable del deudor". Al lado de estas reglas, existían una serie de disposiciones en las cuales se regulaban casos específicos de incumplimiento ( $\$ \S 280,286,325$ y 326, sobre las consecuencias de la imposibilidad que sea atribuible al deudor y la mora), además de las reglas especiales para relaciones obligatorias provenientes de tipos contractuales concretos (como es el caso 463), cuya función era "ampliar la responsabilidad del deudor, en cuanto a sus consecuencias jurídicas, en los casos especiales allí regulados de inejecución o ejecución defectuosa, es decir conceder un resarcimiento de los daños derivados del incumplimiento, lo que en prestación demasiado restrictiva del § 276 del BGB, la que hizo surgir la laguna. El legislador, así como la jurisprudencia anterior a la expedición del BGB, no tenían ninguna duda de que supuestos como la ejecución defectuosa o la violación de deberes accesorios daban lugar a un resarcimiento del daño ocasionado. Se consideraba entonces evidente que si el deudor debía responder por un comportamiento doloso o culposo (\$ 276 del BGB), tenía que resarcir el perjuicio causado al acreedor." Véase, SCHNEIDER, WinfriedThomas, Abkehr vom Verschuldensprinzip, Mohr Siebeck, Tübingen, 2007, pp. 60 y ss.

${ }_{188}$ STAUB, Hermann, El origen de las llamadas lesiones contractuales positivas, las expone en su trabajo publicado "Die positiven Vertragsverletzungen, Berlín, 1904, pp. 29 y ss.; Posteriormente reeditado en una monografía cuya $2^{a}$ edición en 1913 y por último una reimpresión en 1969 con el epílogo de ScHMIDT, Eike, Nachwort zu Rudolf Jhering's, culpa in contrahendo uns Staub's' positiven Vertragsverletzungen, Neudruck, Bad Homburg, Berlin, Zürich, 1969. 
deudor haga lo que debió omitir o ejecutará la prestación pero en forma defectuosa e insatisfactoria para su acreedor.

A estas situaciones de incumplimiento las denomino como violaciones positivas del contrato (positiven Vertragsverletzungen). Para algunos autores, esta interpretación dada por Staub al BGB, fue condicionada por su cultura jurídica proveniente del ordenamiento Prusiano, pues él ejercía allí como abogado. En efecto, en el Código Prusiano, se preveía claramente el resarcimiento en caso de lesión de un deber (Pflichtverletzung) (I. 5, $\S \S 285$ y ss.), expresamente se fundaba la responsabilidad del deudor en toda negligencia. De ahí, se cree que Staub echara de menos en el BGB ese tipo de reglas que sancionaran explícitamente un comportamiento positivo o violación de un deber, contrario al contrato por parte del deudor. ${ }^{189}$

Con el adjetivo "positivo", Staub quiso proporcionar una característica que unificara y que a la vez fuese diferenciadora frente a los supuestos de lesión legalmente previstos -y que suponen un no hacer, bien porque la prestación deviene imposible, o bien porque el deudor incurre en un retraso.- El régimen de responsabilidad que se aplicaba a estos casos -violación positiva- era el contractual y para justificarlo se recurrió a la aplicación analógica de los preceptos que regulan la mora y la imposibilidad. ${ }^{190}$

Para este autor, resulta evidente que los daños que el cumplimiento inexacto provoca en el objeto del contrato han de repararse en base a los principios contractuales, esta misma obviedad

\footnotetext{
${ }^{189}$ SCHERMAIER, Martin Josef, "Leistungsstörungen” vor $\S \S 275$, en HKK, № 84, pp. 926 y SS.

${ }^{190}$ AsÚA GONZÁleZ, Ob. Cit., p 34.
} 
también la entiende respecto a los daños producidos mediante una prestación no cuidadosa, (unsorgfältige Leistung) en este caso los daños se causan a bienes diversos de los que constituyen el objeto de la prestación principal, resultando así incluidos en estas lesiones positivas el interés a la integridad (Integritätsinteresse) física y en la propiedad en el ámbito de la protección del contrato. ${ }^{191}$

Con el acogimiento masivo y expedito de la teoría de Staub, primero por la doctrina y luego por la jurisprudencia, ${ }^{192}$ se reintroduce en el escenario jurídico el concepto de "violación de un deber" (Pflichtverletzung) en el régimen de perturbación de la prestación. Trasladando la atención de una idea de inejecución (Nichterfüllung) a una retórica de los deberes, ${ }^{193}$ que al mismo tiempo implicaba un

191 CABANILLAS SÁNCHEZ, Los deberes de ... Ob. Cit., p. 149.

192 El RG, en la sentencia de 19 de julio de 1914, acogiendo una demanda de resarcimiento, fundó la responsabilidad del hotelero, considerando que forma parte de las obligaciones contractuales el deber del propietario de un local de proporcionar seguridad a sus clientes. Véase, (RGZ) Entscheidungen des Reichsgerichts in Zivilsachen, 1915, pp. 185 y ss.; También El RG en sentencia de 15 de marzo de 1915, estableció la responsabilidad contractual de una empresa ferroviaria, en relación a los daños sufridos por una persona que entrado en la estación y mientras se acercaba el tren resbalo hiriéndose a causa de la nieve caída durante la noche. Esta responsabilidad imputada por el RG fue en base al contrato de transporte, ya que la sociedad ferroviaria debía haber aportado todas las medidas adecuadas para evitar que fuese puesto en peligro la integridad del viajero. Véase, RGZ) Entscheidungen des Reichsgerichts in Zivilsachen, 1915, pp. 321 y ss.; En el mismo sentido, la sentencia del 2 de julio de 1915, fundo la responsabilidad del dueño de una hostería, por los daños experimentados por un cliente, que mientras se dirigía a una sala situada en el piso superior, tropezó a causa de la escasa iluminación de la escalera del acceso. EI RG condeno al Hostelero a titulo de responsabilidad contractual, derivada del deber de adoptar todas las medidas necesarias a fin de que los clientes pudieran moverse sin ningún peligro en los locales puestos a su disposición. Véase, (RGZ) Entscheidungen des Reichsgerichts in Zivilsachen, 1916, pp. 128 y ss.

${ }^{193} \mathrm{Se}$ debe tener presente la ambigüedad terminológica existente en el ámbito alemán alrededor de la palabra Pflicht, que puede bien significar tanto obligación como deber. Al respecto advierte claramente Martin Josef Schermaier: "La lengua alemana permite ocultar esta diferencia: lo que el francés distingue con obligation y devoir, el inglés con obligation y duty, abarca en el alemán formal con "Leistungsstörungen" y "Sorgfaltspflicht" [...] En realidad, a pesar de que desde el BGB de 1900 se hubiera adoptado este uso idiomático, se trata de dos niveles diferentes de deberes: la obligación a la prestación se encuentra a su vez sometida al deber de cumplirla de acuerdo con "la buena fe atendiendo a los usos del tráfico" (\$ 242), que significa entonces que se debe observar en la ejecución "la diligencia exigida en el tráfico" (\$ 276 II) En otras palabras, la observancia del "Leistungsstörungen" se encontraba sometida a la exigencia de un "Sorgfaltspflicht". Por lo 
cambio en la comprensión del contenido de la obligación, pues éste ya no dependía del resultado de la prestación, sino del deber impuesto al deudor. ${ }^{194}$

Con todo, el desarrollo de las lesiones positivas contractuales en la doctrina, trajo consigo la atención de esta última sobre la multiplicidad de los posibles deberes que podían surgir de una relación obligatoria concreta, conduciendo con ello a una tipificación y sistematización de los mismos, pues, sin duda, la variedad de casos que estaba llamada a cobijar era amplia y heterogénea.

En esto orden de cosas, Stoll ${ }^{195}$ elaboró una completa categorización de los deberes secundarios de prestación. En este sentido, realizó una importante distinción, entre los deberes que sirven al interés en la prestación y los deberes de salvaguarda o tutela de la integridad de la persona y los bienes de los contratantes. De esta forma, los deberes que resultan del contenido del contrato, tiene una finalidad positiva, por cuanto, sirven al logro del interés en la prestación, a estos deberes los denomino deberes de ejecución (Erfüllungspflichten).

Por su parte, los demás deberes que no asuman un rol directo en el provecho de la prestación, tienen un interés negativo, por cuanto, se traduce en la abstención de cualquier efecto perjudicial, toda vez, que buscan proteger a la contraparte, para no sufra daños

\footnotetext{
que se confunden dos planos, cuando se equiparan las violaciones de ambos Pflichten. $Y$ sin embargo, cuatro años después de la modernización del Derecho de obligaciones, prevalece la idea de que se debe encuadrar el incumplimiento mismo (Nichterfüllung) como la violación de un deber (Pflichtverletzung)". Véase, SCHERMAIER, Martin, "Leistungsstörungen" en HKK, §§ 280- 285, $N^{\circ} 2$, pp. 1181 y ss.

${ }_{194}$ RODRÍGUEZ OLMOS, Ob. Cit., p. 310.

${ }^{195}$ STOLL, Ob. Cit., pp. 289 y ss.
} 
que podrían resultar de la relación particular que se crea entre las partes. Estos deberes, no sirven al interés de la prestación sino al interés en la protección y salvaguarda del acreedor, de ahí que estos deberes se denominan deberes de protección.

En síntesis, la inobservancia de los deberes de protección, en el periodo de vida del contrato, generarán eventuales daños en el patrimonio o la persona de la contraparte, daños que importan una violación o lesión positiva del contrato o un cumplimiento defectuoso del mismo, lo que equivale a afirmar que esa violación se traduce en la inobservancia de la orden preceptiva instituida en el contrato por la buena fe. ${ }^{196}$

b.- El nacimiento de la obligation de sécurité

De manera paradojalmente simultánea ${ }^{197}$ a la doctrina de los deberes de protección en Alemania (schutzpflichten), nace en Francia la denominada teoría de las obligaciones de seguridad (obligations de sécurité), propuesta por primera vez por la Cour de Cassation en la redacción de la famosa sentencia "Zbidi Hamida Ben Mahmoud con Compagnie génerale transatlantique", de fecha el 21 de noviembre de $1911 .{ }^{198}$

\footnotetext{
${ }^{196}$ CABANILlas SÁnChez, Los deberes de ...” Ob. Cit., p. 157.

${ }^{197}$ Con toda razón, la doctrina italiana al referirse a los deberes de protección y las obligaciones de seguridad, subraya la similitud existente entre ellos. Por todos véase, MENGONI, Luigi, "Obbligazione di resultato e obbligazioni di mezzi" (studio critico), Rivista di Diritto Commerciale, 1954, p. 368.

198 "Zbidi Hamida Ben Mahmoud con Compagnie génerale transatlantique" en Dalloz. Recueil pédiodique et critique de jurisprudence, de législation et de doctrine, 1913, p. 249;
} 
El desenvolvimiento de las obligations de sécurité, aparece íntimamente ligada a los cambios experimentados por revolución de los medios de transporte a finales del siglo XIX, por cuanto, estos nuevos tipos de movilización en masa, multiplicarán de igual forma tanto el número de pasajeros como el riesgo relativo de accidentes de los mismos. ${ }^{199}$

Con la inevitable llegada de la revolución industrial y el correspondiente desarrollo del maquinismo, los jueces de fines del siglo XIX y comienzos de XX, fueron confrontados a nuevos problemas, de los que los redactores del Code no suponían su amplitud, y para los que, de todas maneras, no parecían manifestar más que un mínimo interés. ${ }^{200}$

En Francia hasta principios del siglo $X X$ el criterio jurisprudencial había sido considerar la responsabilidad del transportista de personas como responsabilidad delictual. ${ }^{201}$ Esta

también en, "La Cour de Cassation 1790-1990", en Catalogue de l' exposition du bicentenaire, París, 1990, p. 84.

${ }^{199}$ Un ejemplo en este sentido es la tragedia del Titanic en 1912. "Uno podría argumentar que había muchas diferencias entre el hundimiento del gigante de los mares británicos y los accidentes ferroviarios de principios del siglo, con el origen de esta nueva jurisprudencia francesa. No obstante, el factor común entre ambos casos, estriba en la legitima expectativa de seguridad de los pasajeros y la responsabilidad del transportista en llevarlos sanos y salvos a destino." HALPÉRIN, Jean-Louis, "La naissance de l'obligation de sécurité", Gazette du Palais, 1997, p. 2.

${ }^{200}$ HOCQUET-BERT, Sophie, Obligation de moyens ou obligation de résultat? À propos de la responsabilité civile du Médicin, Atelier national de reproduction des thèses, Lille, 1995, p. 255.

${ }^{201}$ Hasta 1911, la jurisprudencia francesa, ante la ausencia de textos legales referidos a la responsabilidad del portador en el transporte de personas, fundamentó la responsabilidad del mismo fuera del ámbito contractual. Se rechazaba así la aplicación de las normas de la responsabilidad contractual del transportista de mercancías (art. 1.784 CC. Francés) al transportista de personas, aplicando a éste exclusivamente las normas sobre la responsabilidad civil extracontractual de los artículos 1.382 y ss. CC. Francés. De tal manera que el viajero lesionado, o sus causahabientes en caso de accidente mortal, 
figura, es un fiel reflejo de la tradición jurídica heredada del Derecho romano. Esta, concedía poco sitio al transporte de los viajeros y a la responsabilidad del transportista en caso de accidente.

En el Derecho romano, debemos recordar, el edicto del pretor se había interesado únicamente por la salvaguardia de las mercancías, el equipaje y animales confiados a los capitanes de buques, los posaderos y los propietarios de cuadras en virtud de un pacto cualificado según el caso de "receptum nautarum", "cauponum, o stabulariorum". ${ }^{202}$ En contraposición a ello, el daño causado a las personas por un accidente de transporte no era objeto de disposiciones particulares que se derivaban del contrato. ${ }^{203-204}$

Con la codificación la historia no varió en demasía, toda vez, que continuó en lo relativo a los transportistas, siendo devota a la tradición latina. ${ }^{205}$

estaban sujetos a la prueba de una imprudencia o negligencia del transportista Véase, CABANILLAS SÁNCHEZ, Los deberes de ... Ob. Cit., pp. 168-169.

202 ZIMMERMANN, Law of Obligations ... Ob. Cit., pp. 517-518.

${ }^{203}$ Esta laguna del derecho romano respecto a la responsabilidad del transportista de personas explica la actitud de los juristas de la época. El contrato de transporte suscita poco interés en la antigua doctrina, en particular cuando se trata de la suerte de los viajeros. El transporte de las mercancías es tratado a propósito del contrato de comisión, la responsabilidad del transportista (que él sea marítimo o terrestre) apreciándose según las reglas del receptum nautarum. En cuanto a la responsabilidad delictual nacida de la lex Aquilia, continúa aplicándose esencialmente a los daños causados a las cosas. Los accidentes sobrevenidos durante un transporte terrestre son contemplados solamente respecto al descuido o a la impericia reprochada por el cochero, sin que se distinga, entre las víctimas, los pasajeros de las cosas aplastadas por el vehículo. Véase, HALPÉRIN, Ob. Cit., p. 2.

${ }^{204}$ Ya aparece en el Digesto (D. 14. 2, 2, 2,) a propósito de lex Rhodia de jactu, el transporte de personas libres, fue asimilado al transporte de mercancías cada vez en que la naturaleza de las cosas no se opusiera a ello.

${ }^{205}$ Para un análisis de la formación del Code y de su estructura, así como en relación con su carácter de modelo de codificación en Europa e Iberoamérica durante el siglo XIX, DEZZA, Ettore, Lezioni di Storia della codificazione civile. Il Code Civil 1804 e l'Allgemeines Bürgerliches Gesetzbuch (ABGB, 1812), Giappichelli, $2^{\text {a }}$ edición, Torino, 2000, pp. 85-88 y GUZMÁN BRITO, Alejandro, La codificación en Iberoamérica, Editorial Jurídica de Chile, Santiago, 2000, pp. 307 y ss.; CARONi, Pio, "La historia de la codificación y la historia del Código", en Revista Catalana d'historia del dret, 5, 2000, pp. 403-431, quien hace una 
En este sentido el Code, se ocupo del transporte, ${ }^{206}$-tanto por tierra como por mar-, solo a propósito del alquiler de obra y de industria y les somete a obligaciones particulares para la guarda y la conservación de las cosas que les son confiadas, haciéndoles responsables en caso de pérdida o de avería a menos que prueben sólo han estado perdidas y son estropeadas por caso fortuito o fuerza mayor (art. 1784 CC. Francés), idéntica regla se consagrada en el Código de comercio en su artículo 103 en el título VI del libro I consagrado a los comisionistas. ${ }^{207}$

\section{La celebre sentencia de 1911, considerada como fundadora de} la obligación de seguridad, ${ }^{208}$-revalidada por la corte de casación en

distinción entre la historia del Código y la historia de la codificación en Europa. Una visión crítica al Code como modelo europeo puede leerse en el trabajo de SolEIL, Sylvain, "EI Código Civil de 1804 ¿ha sido concebido como un modelo jurídico para las naciones?", trad. por Sebastián Ríos Labbé, en María Dora Martinic G. y Mauricio Tapia R. (directores) Sesquicentenario del Código Civil de Andrés Bello. Pasado, presente y futuro de la codificación, Lexis Nexis, 2005, t. I, pp. 45 y ss., quien cita abundante bibliografía sobre el problema. Véase también BEAUTHIER, Régine y RORIVE, Isabelle (coord.), Le Code Napoleón, un ancêtre vénéré?, Mélanges offerts à Jacques Vanderlinden, Bruylant, Brúselas, 2004, en el que se analizan las influencias del Code en Italia, Alemania, Polonia, Holanda y en el Common law. De hecho, toda la segunda parte de la obra está dedicada a la imagen del Code en el sistema anglosajón. Al respecto, puede destacarse especialmente BENED WALTERS, Dafydd, "L'image du Code dans le contexte de la Common law en Grande- Bretagne et dans le Commonwealth britannique", en Régine Beauthier e Isabelle Rorive (coord.), Le Code Napoleón, un ancêtre vénéré? Mélanges offerts à Jacques Vanderlinden, Bruylant, Bruselas, 2004, pp. 135-156.

${ }^{206}$ Las modalidades del arriendo de servicios o de cosas, el contrato de transporte no es no siquiera nombrado en cuanto tal por lo grandes comentaristas del Código Civil. La materia, considerada como secundaria, es dejada a los mercantilistas, El artículo 1.784 es la aplicación pura y simple de los principios del derecho común, pero solo se trata de transporte de mercaderías. LYON-CAEN, Charles y RÉNAULT, Lois, Précis de droit commercial I, Librairie Cotillon, París, 1884, № 892, p. 473.

${ }_{207}^{207}$ HALPÉRIN, Ob. Cit., p. 2.

${ }^{208}$ Para algunos autores el origen del estatuto estaría en la legislación sobre accidentes del trabajo de fines del siglo XIX, toda vez que, la industrialización determinó un aumento considerable del número de accidentes de trabajo. Los hábitos de razonamiento de la época conducian a plantear el problema de la indemnización de las víctimas en términos de la responsabilidad delictual. El artículo 1.384.1 CC, no habiendo sido todavía descubierto, el obrero víctima (o sus herederos) solo podía dirigirse contra el empresario en virtud del artículo 1.382, debía pues probar su culpa al no conseguirlo normalmente, quedaba en la miseria. Para ayudarlo, algunos autores propusieron un nuevo análisis del contenido del 
la sentencia de 27 de enero de 1913- dio un giro transcendental en el criterio jurisprudencial anterior.

El emblemático pronunciamiento declaró, que la responsabilidad por los daños sufridos por los pasajeros no era de naturaleza delictual, sino de índole contractual. En efecto, existe un contrato de transporte entre el acarreador y el viajero, en virtud del cual el primero promete al segundo no solo llevarlo de un lugar a otro, sino en asegurarle su indemnidad durante toda la trayectoria del recorrido, es decir, de conducirlo sano y salvo al destino preestablecido. ${ }^{209}$

Con inusual humor, hacen fe de este razonamiento años después los hermanos Mazeaud: "El viajero quiere, desde luego, que la compañía le garantice su seguridad, exige incluso cierto confort, variable, en otro aspecto, según la clase elegida. Así, en invierno quiere calefacción, por lo tanto, tendrá derecho a intentar contra la empresa una acción de responsabilidad contractual si cae enfermo a consecuencia de una insuficiente calefacción de los vagones (...), pues no se concibe, por ejemplo, que un transportista se libere de la

contrato de trabajo. El empresario era, ciertamente, deudor del salario, pero además, debía, se pretendía, garantizar contractualmente la seguridad de sus obreros. En caso de accidente sería responsable por el solo hecho del incumplimiento de su obligación de seguridad: el obrero podía ser indemnizado en el plano contractual, sin tener que probar la del empresario. CABANILLAS SÁNCHEZ, Los deberes de ..." Ob. Cit., p. 171. Véase también: SAUZET, Marc, "De la responsabilité des patrons vis-à-vis des ouvriers dans les accidents industriels", en Revue Critique Législation et. Jurisprudence, 1883, pp. 596 y ss. En el mismo sentido: SALEILLES, Raymond, Les accidents de travail et la responsabilité civile (Essai d'une théorie objective de la responsabilité délictuelle), Librairie Nouvelle de Droit et de Jurisprudence, París, 1897, pp. 3 y ss.

${ }^{209}$ PRADEL, Xavier, Le préjudice dans le droit civil de la responsabilité, Libraire Générale de Droit et de Jurisprudence, París, 2004, p. 323; LAPOYADE DESCHAMPS, Christian, Droit des Obligations, Ellipses, París, 1998, p. 120; CABANILLAS SÁnCHEZ, Los deberes de ..." Ob. Cit., p. 169. 
obligación de transportar cuando no conduce sino a destino un cadáver." 210

En este orden de ideas, si el viajero es herido o muere a consecuencia del transporte, el contrato no ha sido cumplido, en este sentido el viajero o sus herederos podrán exigir la reparación del daño, sin tener que probar la culpa del transportista, es decir, la herida o muerte es prueba suficiente del incumplimiento del contrato de transporte y de la responsabilidad contractual sobreviniente. ${ }^{211} \mathrm{~A}$ mayor abundamiento, ocurrido entonces un infortunio, el transportista respondía a título contractual objetivo, ${ }^{212}$ en la cual solo bastaba establecer el incumplimiento de la obligación de seguridad.

Como bien señala Halpérin, el fundamento de la obligación de seguridad es el resultado de una evolución relativamente compleja de la jurisprudencia hasta los años 1911-1913, mucho más que el producto de una doctrina compartida y poco llevada a sistematizar una interpretación objetiva de los contratos. ${ }^{213}$

Da cuenta de lo anterior, la construcción más bien tardía del instituto. Este fue marcado por un completo desinterés por parte de

\footnotetext{
${ }^{210}$ MAZEAUD, Henri y León, TUNC, Andre, Tratado teórico y práctico de la responsabilidad civil, delictual y contractual, t. I, vol. I, traducido por Luis Alcalá Zamora y Castillo, Ejea, Buenos Aires, 1977, p. 219.

${ }^{211}$ CABANILLAS SÁNCHEZ, Los deberes de ...” Ob. Cit., p. 169.

${ }^{212} \mathrm{En}$ virtud de una obligación de resultado, aunque al momento en que la jurisprudencia francesa descubre la obligación de seguridad en el contrato de transporte de personas, las categorías "medios" y "resultado" aún no habían visto la luz. Fue recién en el año 1925 que Rene Demogue, expusiera por primera vez tal distingo, por lo menos en su aspecto terminológico, Véase, MENGONI, Ob. Cit, p. 305.; En el mismo sentido, VINEY, Genevieve, JOURDAIN, Patrice, "Les conditions de la responsabilité", en Jacques Ghestin (sous la direction), Traité de Droit Civil, Librairie Générale de Droit et de Jurisprudence, $3^{\mathrm{a}}$ éd., París, 2006, pp. 453 y ss.; Le TOURneAu, Philippe, Droit de la responsabilité et des contrats, Dalloz, Paris, 2004, p. 666.

${ }^{213}$ HALPÉRIN, Ob. Cit., p. 3.
} 
los civilistas de la época, ajenos a toda discusión en materias técnicas relacionadas a los nuevos medios de transporte. ${ }^{214}$

Será preciso esperar al comienzo del año 1880 para que la doctrina francesa se interrogue sobre la seguridad de las personas en las relaciones contractuales. La cuestión surge a propósito de los accidentes del trabajo cuando aparecen las primeras propuestas de ley (como las de Martin Nadaud en 1880 o de Felix Faure en 1882) a favor de una amplia responsabilidad patronal (con inversión de la carga de la prueba o toma en cuenta del riesgo profesional) y garantía por medio de los seguros. ${ }^{215}$

August Sauzet, ${ }^{216}$ en su obra (1882) distingue una responsabilidad del patrono o empresario de fuente claramente contractual. ${ }^{217}$ En esta creación doctrinal, el autor amplió el principio de responsabilidad contractual de la inversión de la carga de la prueba a la materia de los accidentes del trabajo. En su monografía Sauzet hace una breve alusión al articulo 1.784 del Code, pero sin pronunciarse sobre su aplicación eventual al transporte de personas.

Sin perjuicio de lo anterior, no será hasta irrupción de la obra del jurista belga Sainctelette en $1884,{ }^{218}$ que la idea de una obligación

\footnotetext{
214 HALPÉRIN, Ob. Cit., p. 5.

215 HALPÉRIN, Ob. Cit., p. 6.

216 SAUZET, Marc, Ob. Cit. pp. 596 y ss.

217 Antes de Sauzet, el abogado parisino Vavasseur en una monografía publicado en 1881, pregona por la reforma legislativa que establezca una presunción simple de la culpa del patrono que asumiría igualmente el riesgo industrial delos accidentes. Considera que el artículo 1.382 del Code es inaplicable cuando hay contrato. VAVASSEUR, M, August, De la responsabilité des accidents de fabrique, Marchal-Billard Et, París, 1881, pp. 5-9.

218 SAINCTELETTE, Charles, De la responsabilité et de la garantie, Bruyland-Christophe-, A. Chevalier-Marescq, Bruxelles-París, 1884, pp. 95-118.
} 
contractual de seguridad, se inscribiera en la discusión doctrinal de manera permanentemente.

Para Sainctelette, existe una garantía contractual de seguridad del empresario respecto sus obreros, es decir, existe un deber de garantía del patrono respecto a la vida y seguridad de sus trabajadores. Esta garantía es totalmente diversa al principio delictual non alterum laedere, de claro carácter residual. La trascendencia de esta garantía es dada por el propio contrato, y el incumplimiento de esta obligación convencional da lugar a una indemnización prevista o previsible en el contrato. Bajo estos términos el empresario solo puede librarse de ella probando la culpa del obrero o fuerza mayor. ${ }^{219}$

Sobre el particular, comenta Viney: "Será a partir de los años 1880 a propuesta de varios autores -en particular Sauzet y Sainctelette- que la idea de relacionar o vincular ciertos contratos con una obligación de seguridad tenía un objetivo preciso, el de dar a las víctimas de determinados accidentes corporales, en particular los de trabajo y transporte que preocupaban particularmente a los juristas en aquella época, el medio de eludir la exigencia de la prueba de la culpa personal del empresario o del transportista para obtener reparación. En efecto, combinando el contrato a una obligación de seguridad, estos autores procuraban proporcionarles a los tribunales la oportunidad de justificar la condena sobre el terreno contractual, evitando así la aplicación del art. 1382 CC y, por consiguiente, la necesidad de probar una imprudencia o un descuido personal e individualizado, una prueba que era en realidad imposible desde que,

${ }^{219}$ CABANILLAS SÁNCHEZ, Los deberes de ...” Ob. Cit., p. 173. 
como era más a menudo el caso en aquella época, el accidente se debía a un defecto del material."220

Rápidamente, el interés de hasta entonces la esquiva y desatendida doctrina civilista francesa, vuelca su total atención hacia a este nuevo tipo de obligación.

En tal sentido, nos ilustra el profesor Halpérin: "En respuesta a las publicaciones de los años 1882 y 1884, -Sauzet y Sainctelettenumerosos autores se declararon a partidarios de la aplicación de los principios de la responsabilidad contractual en los accidentes de trabajo o de transporte. Para algunos, se trataba sobre todo de criticar la evolución de la jurisprudencia en materia de transporte ferroviario. Para otros, como Labbé, Glasson o Planiol, debate se sitúa sobre todo en el terreno de los accidentes del trabajo. La adhesión a las posiciones de Sauzet y Sainctelette del grande civilista Labbé, considerado como el primero de los comentarista, es particularmente significativo. Mientras que este había defendido hasta entonces el sistema de la culpa probada (afirmaba que no existía injusticia en ver daños no reparados), Labbé se pronuncia a partir de 1885 a favor de la responsabilidad contractual del patrono. Justificando la inversión de la carga de la prueba por la aplicación de los principios generales del código Civil. Esta posición, manifiestamente inspirada por el temor de una ley política, que privilegiara a los obreros, es sin embargo, menos avanzada que la de Sainctelette, ya que, admite las cláusulas de irresponsabilidad y permite al patrono probar que adopto todas las

\footnotetext{
${ }^{220}$ VINEY, Genevieve, "Rapport de synthèse", en La naissance de l'obligation de sécurité, Gazette du Palais., 1997, p. 39.
} 
precauciones posibles, No obstante, esta interpretación liberal, resulta muy poco favorable a los obreros."221

Esta tesis contractual se acentúa en los autores Glasson y Planiol. El primero, en su celebre estudio sobre el código civil y los obreros, ${ }^{222}$ se inclina por la responsabilidad contractual, pero no afirma la inversión de la carga de la prueba, la culpa no se supone.

El segundo, en un examen doctrinal aparecido en $1888,{ }^{223}$ afirma igualmente que el obrero no está dispensado de probar la culpa contractual del patrono. Así enmendada (por no decir, desnaturalizada), la responsabilidad contractual no aportaba ninguna mejora a la situación de las víctimas de accidentes y conducía los mismo resultados que la vieja idea del riesgo voluntariamente asumido por el contratante.

En tales condiciones, la idea de una obligación de seguridad con fundamento contractual, tenia pocas posibilidades de triunfar tanto en la jurisprudencia como en la legislación francesas, lo que provocó un rechazo muy rápido en los teóricos.

Ya en la década de los noventa los adversarios a la tesis contractual eran numerosos. ${ }^{224}$ Refuerza esta tendencia, la tesis sostenida en 1896 por Albert Zens, ${ }^{225}$ en esta se marca un claro

\footnotetext{
${ }^{221}$ HALPÉRIN, Ob. Cit., pp. 6-7.

${ }^{222}$ GLASSON, Ernest, Le Code civil et la question ouvrière, Librairie Cotillon, París, 1886, pp. 866-871.

${ }^{223}$ PlANiOL, Marcel, Revue Critique de Législation et de Jurisprudence, París, 1888, pp. 278-284.

${ }^{224}$ HALPÉRIN, Ob. Cit., p.7.

${ }^{225}$ ZENS, Albert, De la responsabilité du voiturier à raison des accidents de personnes, Thèse, París 1896, pp.126-146.
} 
retroceso de la postura contractual en los accidentes del trabajo y transporte. Se descarta radicalmente la teoría de Sainctelette por ser artificiosa, reduciendo la obligación del transportista a la puesta en practica de las mejores condiciones de seguridad incumbiendo la prueba de la culpa a la víctima.

En materia de accidentes de trabajo, la discusión parlamentaria será marcada por el rechazo de la responsabilidad contractual, por otro lado, la mayoría de los civilistas, a semejanza de Planiol, ${ }^{226}$ abandonarán prontamente el fundamento contractual. ${ }^{227}$

En este estado de cosas, la reciente teoría de la obligación de seguridad había sido relegada en menos de diez años, a unas pocas defensas aisladas de los que aún tenían el convencimiento de que esta podía dar alcance a las injusticias cometidas tanto en los accidentes de trabajo como de transporte. No obstante, solo un par de años después, un segunda variante llegaría proveniente de la corriente más innovadora de la dogmática teórica francesa, a sustituir el desfallecido fundamento contractual en la responsabilidad empresarial.

Es con la llegada del principio un revolucionario -hasta ese entonces- de responsabilidad fundada sobre el riesgo, que el panorama para la responsabilidad empresarial o patronal cambiara drásticamente. En 1890 Saleilles, ${ }^{228}$ representó un paso valioso en la

\footnotetext{
${ }^{226}$ Planiol, Marcel, Traité élémentaire de droit civil, t. II París, 1912, p. 579.

227 HALPÉRIN, Ob. Cit., p. 7.

228 SALEILLES, Raymond, Les accidents de travail et la responsabilité civile... Ob. Cit., p. 20.; también en SALEILLES, Raymond, "Le risque professionnel dans le Code civil", communication à la société d' Economie Sociale, en La reforme Sociale, 1998, p. 641.
} 
construcción de una nueva teoría, capaz de proporcionar una adecuada justificación a la responsabilidad civil.

Este da justa cuenta del fracaso de la tesis contractual, por considerar que eran inadmisibles en virtud del art. 1.160 del Code cláusulas tácitas destinadas a completar las disposiciones expresas de un contrato.

En este orden de ideas, plantea como solución, la separación de toda idea de culpa y la admisión del riesgo profesional como fundamento de la responsabilidad empresarial. ${ }^{229} \mathrm{El}$ mismo año Josserand aboga por una responsabilidad legal a causa de cosas inanimadas (sobre la base del riesgo creado en art. $1384.1 \mathrm{CC}$.), que no se limita al dominio industrial, ya que, la obligación nacida del hecho de la industria debe ser sustituida por una obligación surgida del hecho de las cosas, y la noción de riesgo profesional por la de riesgo creado. Es en este último donde se encuentra el fundamento de las responsabilidad e las cosas inanimadas. ${ }^{230-231}$

Posteriormente, se producen sobresalientes cambios legislativos, como la promulgación de la Ley de 9 de abril de 1898,

${ }^{229}$ CABAnIllas SÁnchez, Los deberes de ...” Ob. Cit., p. 175.

${ }^{230}$ JosserAND, Louis, De la responsabilité du fait des choses inanimées, Librairie Nouvelle de Droit et de Jurisprudence, París, 1987, p. 105.

${ }^{231}$ Como afirma Viney: "El primer éxito de la responsabilidad sin culpa se fundó en el artículo 1.384.1 CC, concretamente en la famosa sentencia "Teffaine" del Tribunal de Casación de 18 de julio de 1896, que es aplicado a los accidentes del trabajo, con preferencia a la obligación contractual de obligación, es por todas razones que se enmarcan esencialmente de la ideología jurídica de finales del siglo XIX, de la que el comentario de Saleilles a la sentencia de Teffaine da perfecta cuenta. Saleilles, insiste que tratándose de Derecho privado, es preciso atenerse a los principios formulados en los textos. La referencia al artículo 1.384 satisfacía tal exigencia. Dicho autor destaca la desconfianza que existía en esa época -donde el principio de autonomía de la voluntad gozaba de un gran prestigio- sobre las clausulas tácitas destinadas a completar las condiciones expresas de un contrato." VINEY, Genevieve, "Rapport de synthèse".....Ob. Cit., p. 39. 
que estableció un régimen de responsabilidad sin culpa en materia de accidentes del trabajo, con el descubrimiento del artículo 1.384 .1 del Code, siguiendo la nueva teoría del riesgo. ${ }^{232}$

En doctrina autores de la talla de Teisseire y Vansteeberghe, se pronuncian a favor de una responsabilidad del transportista por hecho de las cosas, lo que solucionaba, ciertamente, la cuestión de la prueba de manera ventajosa para los pasajeros. ${ }^{233}$ Por su parte, Josserand reafirmaba su tesis a favor de una responsabilidad legal, objetiva y fundada en el riesgo. 234

Increíblemente, en los años precedentes a la sentencias decisivas de la corte de casación de 1911 y 1913, la obligación de seguridad no tenia muchos adeptos en la doctrina francesa. ${ }^{235}$ Entonces, ¿Como se explica, que el fundamento de estas celebres sentencias, sea el contenido en una obligación de seguridad de naturaleza contractual?.

Al respecto, podemos identificar dos factores relevantes que intervienen en la adopción decisiva de este tipo de obligación. El primero, la inclinación hacia una responsabilidad fundada en el riesgo creado basada en el descubrimiento y aplicación del artículo 1.384.1 del Code, no tuvo la fuerza ni el apoyo suficiente para descartar definitivamente la propuesta de una obligación contractual de seguridad, mucho más cercana y útil al pragmatismo propio de los tribunales en la aplicación de la ley.

\footnotetext{
${ }^{232}$ CABAnillas SÁnchez, Los deberes de ...” Ob. Cit., p. 176.

${ }^{233}$ HALPÉRIN, Ob. Cit., p. 7.

${ }^{234}$ JOSSERAND, Loius, "Les transport", en Traité générale théorique et practique de droit comercial, París, 1910, pp. 784-785

${ }^{235}$ CABAnillas SÁnChez, Los deberes de ...” Ob. Cit., p. 177.
} 
Un segundo aspecto lo constituye un mero dato fáctico. Bajo esta perspectiva, se hace notar la gran influencia que tuviese Louis Sarrut, ${ }^{236}$ fiscal general del máximo Tribunal Supremo, y considerado uno de los últimos y más fervientes defensores de la tesis contractualista. ${ }^{237}$

Así las cosas, finalmente llega la celebre sentencia de la Cour de Cassation, el 21 de noviembre de 1911 (asunto Zbidi Hamida ben Mahmoud), en la cual se invoca mediante la violación del artículo 1134 del Code, (ejecución de buena fe de los contratos), que la ejecución del contrato de transporte que implica para el transportista la obligación de conducir al viajero sano y salvo a su destino, ("le transporteur de personnes est tenu de l'obligation de conduire le voyageur sain et sauf à destination").

Casi un año después, el mismo tribunal supremo confirmaría solemnemente este criterio, en el fallo de la sentencia de 27 de enero de 1913, bajo la particular redacción del fiscal general y antiguo partidario de la responsabilidad contractual Sarrut. ${ }^{238}$ De esta forma quedará arraigada en la jurisprudencia y doctrina francesa la naciente obligación contractual de seguridad, según la cual, la sola expedición de un pasaje o billete a un viajero implica -y sin que sea necesario

\footnotetext{
${ }^{236}$ La carrera de Louis Sarrut, esta vinculada estrechamente a la historia de la obligación de seguridad: Doctor en derecho de Nancy, publica su tesis sobre el transporte de mercancías por ferrocarril con un prefacio de Chales Lyon-Caen. Luego, defiende la responsabilidad contractual en el Tribunal de Apelación de París (1885). Fue abogado general del Corte de Casación (1891), cargo en el que votará en contra en el fallo Teffaine (Considerada la primera sentencia fundamentada en la responsabilidad del riesgo creado). Presidente de la sala (4 de octubre de 1904). Posteriormente, se hace Fiscal general de la Corte de Casación (16 noviembre 1911). Acaba su carrera como el primer presidente de la Cour de Cassation (1917 a 1925).

${ }^{237}$ VINEY, Genevieve, "Rapport de synthèse"...... Ob. Cit., p. 39.

${ }^{238}$ HALPÉRIN, Ob. Cit., p. 5
} 
expresarlo en una estipulación al respecto-, la obligación para la compañía de ferrocarril, de conducir a este viajero sano y salvo a destino.

El criterio contenido en las sentencia de 1911 y 1913, fue producto de un verdadero recurso de la ingeniería jurídica de aquella época, ante la ausencia de textos legales, que procuró dar cuerpo a nuevas inquietudes axiológicas frente a circunstancias inusitadamente cambiantes propias de una realidad plagada de riesgos, cuyo objeto primordial era alivianar a la víctima en la diabólica carga de tener que constatar -sine dubio- la culpa del transportista. Nada mejor para ello que concebir el contrato en toda su amplitud, más allá de su rol natural de instrumento de canje de bienes y servicios.

c.- Il doveri di protezione

En Italia se aceptó tempranamente la teoría de los deberes contractuales de protección haciendo eco de la doctrina alemana y francesa.

Betti, ${ }^{239}$ se refiere a ellos como obligaciones integrativas, que derivan del principio de la buena fe, y que se diferencian según el criterio de mayor o menor aproximación a la prestación principal. En este sentido, la aproximación es mayor en aquellas obligaciones de custodia y diligencia que son auxiliares e inmediatamente integran la obligación principal. En una posición más distanciada de la prestación

${ }^{239}$ BetTI, Ob. Cit., p. 98 y ss; 
principal, están las obligaciones generales de conservación del interés de la otra parte, que se llaman obligaciones de protección, las cuales están dirigidas a prevenir y alejar daños de la esfera de interese de la contraparte.

Benatti, realiza una exhaustiva revisión de los deberes de protección, tanto en la doctrina italiana como en el derecho comparado de la época, al respecto señala: "Nuestra doctrina hasta ahora no le ha prestado particular atención a la cuestión de si resulta de naturaleza contractual o extracontractual la responsabilidad de quien hubiere causado, durante la ejecución de un contrato, daños a la persona o a las cosas de su contraparte. Por el contrario, en donde resultan numerosos los pronunciamientos jurisprudenciales en esta materia, como en Alemania y en Francia, la doctrina se ha ocupado extensamente de la cuestión." 240

Para este autor, existe un denominador común entre ambas teorías alemana y francesa (Schutzpflichten y Obligations de Sécurité), en el hecho de atraer a la esfera de la responsabilidad contractual, sobre la base de la circunstancia que ciertos daños son causados durante la ejecución de un contrato, hechos que de por sí ingresarían en el campo de la responsabilidad extracontractual.

Agrega en este sentido: "Ambas teorías han sido inspirada por decisiones jurisprudenciales que se presentaron debido a exigencias prácticas. Tanto los deberes de protección como las obligaciones de seguridad están fundadas sobre el principio de la buena fe. Las dos

\footnotetext{
${ }^{240}$ BENATTI, Francesco,"Osservazioni in tema di doveri di protezione" en Rivista trimestrale di diritto e procadura civile, anno XIV, Giuffrè, Milano, 1960, p. 1342.
} 
categorías de deberes están sometidas a la misma disciplina en cuanto a la carga de la prueba" ${ }^{241}$ Sin perjuicio de aquello, reitera Benatti, la doctrina italiana ha dedicado escasa consideración a las "obligations de sécurité" y si se ha ocupado, prevalentemente, de los "deberes de protección".

Para Mengoni, ${ }^{242}$ los deberes de protección no son una variable dependiente de la disciplina extracontractual. Por el contrario, admite que estos en virtud de la buena fe acceden a la relación obligatoria en razón del interés de cada parte a preservar la propia persona y las propias cosas de la especifica posibilidad de daño derivada de la particular relación constituida entre los dos sujetos.

Para este autor, los deberes de protección tienen un fin puramente negativo, esto es, de mera conservación del patrimonio de a otra parte. Los deberes de protección son deberes esencialmente recíprocos en contraste a los deberes de prestación típicos de la posición jurídica del deudor.

Por su parte Di Majo, ${ }^{243}$ señala que un cabal desenvolvimiento de la relación obligatoria puede estar ligado con intereses que no se identifican solamente con el interés en la prestación, entendida en sentido estricto, como intercambio de bienes o utilidades. La creación y el desarrollo de una relación obligatoria puede constituir la causa o la ocasión para la lesión de intereses que pueden no haber sido expresamente asumidos como objeto de la obligación.

\footnotetext{
${ }^{241}$ BenATtI, Ob. Cit., p. 1348.

${ }^{242}$ Mengoni, Obligazioni di ...Ob. Cit., pp. 368.

${ }^{243}$ DI MAJO, Adolfo, "Delle obligazioni in generale" en Commentario del Codice Civile Sciloja e Branca, acura de Grancesco Galgano, Bologna-Roma, editore società editrice del foro italiano, 1988, pp. 121 y ss.
} 
Este autor, acoge la extensión de la noción de "prestación" más allá del bien o utilidad, objeto de intercambio. La técnica de los deberes de protección cubren aquellas hipótesis, en que intereses cuya exigencia de protección o tutela puede ser simplemente "ocasionada" por la presencia de una relación obligatoria. Desde este punto de vista, el interés de protección goza de plena autonomía respecto del interés en la prestación.

Vicenzo Roppo, a propósito de nuestro particular objeto de estudio, nos señala: "Justamente al inicio del libro "De las obligaciones" se fija un importante principio general, que ilumina toda la regulación de la relación obligatoria; "el deudor y el acreedor deben comportarse según la regla de la corrección" (artículo 1175). Esto significa que el deudor debe hacer cuanto sea razonablemente posible para maximizar la utilidad que el acreedor recibe de la prestación. El acreedor, por su parte, debe hacer cuanto sea razonablemente posible para minimizar los sacrificios que la prestación impone al deudor." 244

Para Roppo, este principio tiene muchas aplicaciones específicas, sea en ventaja del acreedor, sea en ventaja del deudor. En particular, este principio es el fundamento de los llamados deberes de protección que pesan sobre el deudor. Por regla, el deudor debe una prestación principal, pero a fin de que ésta sea llevada a cabo de la mejor manera, en interés del acreedor, y garantizando la máxima utilidad para éste, puede ser necesario que el deudor realice también

${ }^{244}$ Roppo, Vicenzo, Instituzioni di diritto privato, Bologña, Momdizzi, $3^{\text {a }}$ ed., 2001, p. 265. 
prestaciones accesorias, que resultan instrumentales para el máximo rendimiento de la prestación principal.

Explica que en el derecho italiano se prevén diversos casos: por ejemplo, quien debe entregar una cosa tiene también el deber de custodiarla hasta el momento de la entrega (artículo 1177 C.c. italiano); quien se obliga a realizar un transporte, frente a imprevistos que puedan perjudicar su ejecución regular, debe requerir instrucciones al remitente (artículo 1686 C.c. italiano).

Castronovo, ${ }^{245}$ reflexionando sobre el concepto de relación como categoría esencial de la obligación y de la responsabilidad contractual, expone que es posible entender una obligación sin prestación, considerada esta como una relación que participa de la naturaleza obligatoria de la obligación.

Esta afirmación, tomada sobre el plano puramente textual puede parecer contradictoria, como puede ser una contradicción radical la misma expresión obligación sin prestación. Sin embargo, aquello es debido precisamente a la idea, que ciertamente se tiene por parte de una tradición de más de dos mil años, que identifica la obligación con deber de prestación.

Una vez que se persuada de la posibilidad que la calificación obligatoria se puede extender a otras relaciones según las cuales aquello que sobresale no es la totalidad del contenido sino la dimensión formal, según la cual las partes se hallan una frente a la otra, en aquel momento también la idea de una obligación sin

${ }^{245}$ Castronovo, Ob. Cit., pp. 55- 76. 
prestación no solo no aparece contradictoria, sino por el contrario tiene el mérito que ella se coloca como la verdadera esencia de la obligación, la cual no consiste en su contenido u objeto, más o menos amplio y variado según el tipo contractual que lo genera, sino de la relacionalidad como matriz de calificación de la recíproca colocación de los sujetos el uno frente al otro y en contemplación del otro.

Esta relacionalidad que, en el momento en que se caracteriza la obligación, con o sin prestación, se revela el aspecto constante, el marco dentro del cual la prestación se coloca solo como una variable posible. Donde la relación obligatoria ya no es más la esencia del deber de prestación sino aquella relación constante según la cual en esta perspectiva adquiere un significado nuevo y más específico.

Castronovo, llamará relacional la responsabilidad, sustituyendo a la vez la antigua cuestión terminológica conectada con la calificación "contractual," la cual lingüísticamente está en grado de significar menos de cómo convencionalmente viene descrita, con la asimilación al interior de ella de las relaciones ex lege a aquellas ex contractu. Tal extensión hace que el significado jurídico de la calificación sea considerado obvio pero al mismo tiempo crea el gran compromiso de la claridad.

Por el contrario, la responsabilidad relacional es una expresión que significa la violación de una relación obligatoria, que nace de un contrato o de la ley, sea que la violación se refiera al deber de prestación sea que se refiera a uno de los deberes accesorios o secundarios. Esta responsabilidad deriva de uno o de otro elemento de cuya relación se forma, de la violación de deberes o del 
incumplimiento, ulteriormente aún cuando el deber de prestación se extinga pero igualmente la relación permanecerá porque la ley ha considerado a la relación como jurídicamente relevante.

La responsabilidad llamada contractual ya no es más la responsabilidad por incumplimiento sino responsabilidad por violación de la relación. En este sentido, todo el derecho privado se reconstruye según una summa divisio entre situaciones relacionales, caracterizadas por deberes entre las partes y cuya violación da origen a la responsabilidad precisamente relacional al modo de la responsabilidad por incumplimiento, y situaciones no relacionales, las cuales sobre el terreno de la responsabilidad asumen las características de la responsabilidad aquiliana.

\section{3.- TESIS EXTRACONTRACTUAL}

Existe una doctrina, que si bien minoritaria, sostiene que en realidad no existen deberes especiales de protección, por cuanto estos son en esencia verdaderos deberes delictuales y erróneamente son tratados como deberes negóciales desconociendo su efectiva naturaleza jurídica.

En Alemania, dicha corriente doctrinal funda sus intenciones en los denominados deberes de seguridad del tráfico. En este sentido se 
señala que la lesión a bienes ajenos al contrato en fase precontractual da lugar a la vulneración de deberes de seguridad del tráfico. ${ }^{246}$

Por su parte en Francia, esta corriente doctrinal es cabezada por Jourdain, que aboga en pos de una descontractualización completa de la obligación de seguridad. El argumento para este autor es muy sencillo, la seguridad nada tiene que ver con el contrato. Señala que muy a menudo la pretendida obligación contractual de seguridad no es más que la expresión del deber impuesto por la ley, de no atacar a la seguridad de otro y de la reparación del daño causado injustamente. ${ }^{247}$

Sobre este fenómeno observa Denis Mazeaud: "Si la obligación de seguridad es difícil de aprehender, es por ser el producto de una conciencia judicial espontánea, muy frecuentemente teñida de oportunidad. La obligación de seguridad cuyo descubrimiento y propagación proceden de una inclinación natural de los jueces tiene su sustento basal en el sentimiento de compensación hacia las víctimas de los daños sufridos en ocasión de la ejecución defectuosa de un contrato. Es, en efecto, en interés de las víctimas, para simplificar la puesta en práctica de la indemnización de sus daños, que los jueces han hecho más denso el contenido de los contratos. Pero ello, justificado en sus orígenes atento sus dotes de utilidad y

\footnotetext{
${ }^{246}$ Los deberes de seguridad en el tráfico han sido desarrollados básicamente por la jurisprudencia alemana para justificar la responsabilidad por los dañosa los derechos y bienes mencionados en el $\S 823$.I del BGB que no resulten de un hacer positivo sino de la omisión de medidas para evitar y prevenir daños. El problema se genera, por cuanto el $\S$ 823.I no resuelve cuando una omisión debe considerarse ilícita. La jurisprudencia estableció que la existencia de estos deberes de seguridad en el tráfico supone que quien crea o controla una fuente de peligro debe adoptar las precauciones precisas para no causar daño que afecte a los derecho o bienes jurídicos de un tercero aludido en el $\S 823.1$ del BGB.

${ }^{247}$ JouRDAIN, Patrice, "Le fondement de l'obligation de sécurité", en Gazette du Palais 1997, p. 22.
} 
funcionalidad no legítima por sí una propensión indebida, una añadidura artificial a un gran número de contratos, en cuyo objeto no aparece referencia alguna a la idea misma de seguridad."248

Así las cosas, la sustracción de los daños que por esencia pertenecen in natura a la responsabilidad aquiliana, opera -por lógicaen beneficio de la contractual, bajo una falsa obligación de seguridad, que al contrario de lo que se intenta creer, resulta totalmente desventajosa para el dañado. Máxime si recordamos en esta materia, los plausibles avances que sean desarrollado con la evolución de los criterios objetivos de imputación en materia delictiva, que en determinados casos, generan una verdadera fuente de regímenes especiales de responsabilidad. ${ }^{249}$

En resumidas cuentas la gran objeción que esta corriente efectúa, se sintetiza en el hecho de que si existe un deber general de no llevar a cabo ataques corporales contra el prójimo, el incumplimiento de este deber provoca una responsabilidad evidentemente delictual, y no hay lugar alguno en este sentido, a distinguir según el autor y víctima estén vinculadas o no por un contrato y, si lo están, según lo estuviesen al tiempo de la formación o al tiempo de la ejecución. ${ }^{250}$

\footnotetext{
248 MAZEAUD, Denis, "Le régime de l'obligation de sécurité," en Gazette du Palais 1997, p. 28; BRUN, Philippe, Responsabilité civile extracontractuelle, Litec, Paris, 2005, p. 76.

${ }^{249}$ TeRre François, Simler, Philippe, LequetTe, Yves, Droit Civil. Les Obligations, 8 a éd., Dalloz, Paris, 2002, p. 575; Le Tourneau, Droit de la responsabilité.... Ob. Cit., p. 571; SAVAUX, Eric, "La fin de la responsabilité contractuelle?", en Reveu Trimestrielle de Droit Civil, 1999, p. 10.

${ }^{250}$ REMY, Philippe, "La responsabilité contractuelle: historie d'un faux concept", Reveu Trimestrielle de Droit Civil., 1997, p. 339.
} 


\section{III.- NUESTRA OPINIÓN}

En este punto, conviene hacer una pausa para convencernos de una sutil pero franca reflexión. Parece justificado y al vez ventajoso, dejar un hito que figure como testigo del punto de no retorno de nuestras convicciones iniciales, y que a la vez nos sirva como base sólida de nuestros aciertos en un camino que aún se muestra más poblado de interrogantes que de certezas.

En concordancia a lo expuesto, hemos decidido inclinarnos por la naturaleza contractual de los deberes de protección en desmedro de las otras tesis descritas, ya que, es evidente que es en el ámbito del contrato donde mejor justifica su síntesis, toda vez, que concurren a la realización del objeto de la relación obligatoria considerado en términos globales u orgánicos.

En tal objeto así considerado, comprende no solo la realización de la prestación principal, sino también que de tal realización no resulte daño para las partes. Luego, la sola existencia de deberes de protección u obligación de seguridad, retroalimenta y refuerza el carácter complejo de la relación obligacional, por cuanto, la inobservancia de estos deberes produce ciertamente un ensanchamiento de la responsabilidad contractual, que en nada prejuzga al exacto cumplimiento o no de la prestación principal.

De este modo, la noción de responsabilidad contractual se entiende en toda su dimensión, es decir, frente al incumplimiento en sentido estricto o técnico (de la prestación), surgen igualmente 
supuestos de incumplimientos de estos deberes de protección de naturaleza contractual.

$\mathrm{Si}$ bien, existen justificados antecedentes para entender acertado la vinculación de la culpa in contrahendo en el origen de los deberes de protección, esta concepción resulta muy distintiva y a su vez propia de la cultura jurídica alemana, lo que transforma difícil una traslación de esta génesis a una posible categoría general del instituto, dado los especiales y únicos ingredientes con los que se ha ido integrando dicha teoría.

Por otro lado, si obviáramos por un momento dichas particularidades, en la práctica el resultado aplicable resultaría el mismo, ya que, -como sabemos- tales supuestos de culpa in contrahendo son derivados y amparados por la responsabilidad contractual.

De igual manera, debemos también descartar de plano la tesis extracontractual, por cuanto, esta no encierra más que una mera oposición formal y desprovista de contenido. Pues resulta manifiesto que la existencia de un deber genérico de abstención no se opone normativamente, a un deber especial de protección de intereses de orden contractual. En este contexto, los deberes de protección reciben su determinación de sentido no ya del deber genérico del neminem laedere, sino de la relación específica en que son insertados, pues de ahí emana su autonomía. ${ }^{251}$

\footnotetext{
${ }^{251}$ MENGONI, Luigi, "La parte generale delle obbligazioni", Rivista critica di diritto privato,
} 1984, p. 512. 
Como bien señala Di Majo, ${ }^{252}$ es efectivo y real la exigencia de reforzar, con la protección de la obligación, intereses que de otra manera resultaría protegidos solamente por la vía aquiliana. Si así no fuera, se colocaría a los sujetos de la relación obligatoria en una situación sustancialmente inferior a la de los demás sujetos, porque los riesgos mayores a los que aquellos están expuestos, por el contacto que la obligación ha establecido no tendrían una tutela correspondiente y adecuada.

Este carácter contractual de los deberes de protección, emana del contacto social entre las partes. La noción del contacto social no solo es predicable a la esfera precontractual, sino que también es aplicable con propiedad a la relación contractual ya establecida. ¿Que otra figura más exacta y natural podría existir para el desenvolvimiento de este, sino el contrato?

Es lógico suponer que cuanto más estrechamente un hombre confía su cuidado o el de sus cosas, a la injerencia o dominio de otro, abandonando así su libertad y control sobre ellas, a la actividad de este, más debe aumentar la responsabilidad de quien tiene a su cargo tal labor.

El contacto social, resulta en la práctica mucho más fiel que su génesis precontractual, por cuanto, solo mediante esta especial relación instrumentalizado en el contrato las partes tienen la concreción real de la conciencia, de no causar, apropósito de la ejecución del contrato daños o perjuicios a la otra parte.

252 DI MAJO, Ob. Cit., p. 122. 
En este orden de ideas, será el mismo contacto social el que aleje los deberes de protección u obligaciones de seguridad del genérico ámbito extracontractual y justifique su configuración como auténticos deberes contractuales, autónomos e independientes de la prestación principal y de los demás deberes accesorios relacionados con ella.

Los deberes de protección u obligación de seguridad -como veremos- en virtud de la buena fe, accederán a la relación obligacional en vista del interés de cada parte a preservar la propia persona y bienes de la posibilidad de daño, derivada de la particular relación constituida por ellos.

\section{IV.- CONFIGURACIÓN DE LOS DEBERES DE PROTECCIÓN}

1.- UNA CUESTIÓN PREVIA: DEBERES TíPICOS Y ATÍPICOS

Antes de iniciar el análisis en particular de nuestro objeto de estudio, es preciso advertir al lector sobre un significativo alcance respecto de este último. En este sentido, hemos decidido prudente efectuar una distinción que denota dos clases de deberes: deberes de protección típicos y los deberes de protección atípicos.

Los deberes de protección típicos son aquellos en los cuales el legislador se ha ocupado anticipada y expresamente de la ponderación de los intereses de protección, ya sea, en la persona o 
los bienes de los contratantes. Es la ley, quien ha completado tanto el núcleo como los contornos de la obligación de seguridad, señalando las exigencias concretas de la buena fe, traducidas en la cautela y cuidado efectivo que deben tener las partes en sus relaciones jurídicas en el caso particular.

Un ejemplo de propio de esta clase de deberes se encuentra en la legislación laboral y de accidentes del trabajo, en donde el empleador es ciertamente, deudor del salario, pero además, se constituye como deudor de garantizar la vida y salud de sus empleados, es decir, la prestación comprende la garantía contractual de seguridad de sus trabajadores.

Por su parte, en los deberes de protección atípicos, el legislador no ha efectuado ponderación alguna respecto al interés de protección en una relación jurídica determinada. En este tipo de deber, no se han concretado las exigencias de la buena fe por medio de una ley. Por lo que, será tarea del interprete determinar la existencia de un deber de protección en la convención cuya ejecución pueda afectar la seguridad personal de uno de los contratantes o la de sus bienes.

Esta labor, es de suya compleja, ya que, potencialmente los deberes de protección atípicos existen dentro de cada una de las relaciones contractuales posibles. ${ }^{253}$ Se trata de una serie de carácter numerus apertus, cuya determinación dependerá como veremos de la aplicación de la buena fe contractual al caso concreto.

\footnotetext{
${ }^{253}$ Sin perjuicio de ello, alguna doctrina ha clasificado de manera general los deberes de protección en cuatro categorías: deberes de aviso o de comunicación, deberes de custodia, deberes de conservación o seguridad y deberes de salvamento o rescate. Véase, JORDANO FRAGA, Francisco, La responsabilidad contractual, Civitas, Madrid, 1987, pp. 144-145
} 
Esta distinción propuesta entre deberes típicos y atípicos, resulta vital para la presente investigación, pues, condicionará tempranamente el no ahondar en el estudio de los deberes típicos, ya que, como se ha afirmado, el legislador ha rellenado expresamente su núcleo rector, y concretado así las exigencias de la buena fe con relación a los intereses a proteger, de lo que se sigue, que no existe controversia tanto en su aceptación como en su asimilamiento en el ordenamiento.

Por el contrario, será sobre los deberes atípicos que abocaremos todos nuestros esfuerzos, por cuanto, de lo que se determine respecto de ellos, (naturaleza, oportunidad, efectos, etc.) establecerá la efectiva posibilidad de constituir una categoría general del instituto de los deberes de protección, habilitando así su aplicación dogmática a todo tipo forma contractual.

\section{2.- PREMISAS INICIALES}

Como sabemos hoy, resulta un dato descontado en la ciencia del Derecho que la relación jurídica obligatoria alberga en su seno, sin perjuicio de su unidad, una pluralidad de elementos que conviven y se relacionan en una realidad compleja. En este orden de ideas, la noción de "prestación" se extiende más allá de la utilidad u objeto de intercambio. Esta exigencia significa extender la protección asegurada por la propia obligación, también a intereses que de otra manera se tutelarían en vía aquiliana, es decir, erga ommes y sin distinción. 
Para dicho fin, será necesario plantearnos algunas premisas iniciales en la construcción dogmática de nuestro objeto de estudio. La premisa principal, es comprender que la relación obligatoria constituye una relación especial que se instaura entre las partes, la cual abre la posibilidad de afectar la persona y los bienes de la contraparte.

Consecuencia de lo anterior, será entender que mediante el deber de protección se persigue preservar indemnes las esferas jurídicas de las partes, extendiendo la tutela contractual a bienes o intereses que tradicionalmente eran tutelados bajo las reglas de la responsabilidad delictual.

Para posibilitar dicha abstracción, será necesario afirmar la total autonomía de estos deberes de protección respecto a la prestación. Bajo esta perspectiva, requeriremos conocer a fondo el real contenido del deber de protección y describir sus fronteras como un deber específico y concreto.

a.- Característica elemental: Su autonomía

i.- Antecedentes.

Una consecuencia inmediata del sentido orgánico-complejo de la relación obligacional, se representa en la nota más identificable y característica de los deberes de protección: su autonomía. 
Es así, como junto al interés de realización de la prestación principal convive otro interés distinto e independiente, que se traduce en un genuino deber de conservar íntegramente las esferas jurídicas de los contratantes, tutelándolas de las posibles invasiones lesivas de los mismos. ${ }^{254}$

Sobre este aspecto Stoll, indica que existe una notoria distinción entre el deber de prestación y el deber de protección. El primero es propio de la posición jurídica del deudor y tiende a la realización del interés a la prestación del acreedor, por otro lado los deberes de protección son impuestos tanto al acreedor como al deudor y están dirigidos a satisfacer el interés de cada parte a preservar la propia persona y las propias cosas de eventos lesivos. ${ }^{255}$

Larenz, por su parte entiende que los deberes de protección son netamente distintos al deber de prestación. Bajo esta perspectiva, estima que debe distinguirse entre deberes de prestación (Leistungspflichten) que pueden ser a su vez primarios o secundarios y otros deberes de comportamiento que son básicamente los deberes de protección y lealtad (Schutzpflichten y Loyalitätspflichten). ${ }^{256}$

En Italia la doctrina mayoritaria ${ }^{257}$ sostiene que los deberes de protección responden a un interés de las partes que resulta autónomo

\footnotetext{
${ }^{254}$ Castronovo, Carlo, "Obblighi di protezione" en Enciclopedia Giuridica Trecani, XXI, Roma, 1990, p. 1.

${ }^{255}$ STOLL, Heinrich, "Abschied von der Lehre del positiven Vertragsverleztung" en Archiv für di civilistische Praxis, 1932, pp. 331 y ss

${ }^{256}$ LARENZ, Ob. Cit., pp. 10 y ss.

${ }^{257}$ BENATTI, Francesco, "Osservazioni in tema di doveri di protezione" en Rivista trimestrale di diritto e procadura civile, anno XIV, Giuffrè, Milano, 1960, p. 1342 y ss.; BETTI, Emilio, Ob. Cit., p. 98.; CANNATA, Carlo, Le obbligazioni in generale, nel Tratt. Rescigno, Vol 9, Torino, 1984, pp. 48 y ss.; DI MAJO, Ob. Cit., pp.122 y ss.; CASTRONOvo, Ob. Cit., pp.148 y ss,
} 
al interés de la prestación. Un ejemplo claro de esta visión se encuentra en Mengoni, para el cual los deberes de protección tienen un contenido autónomo e independiente respecto al deber principal de prestación. ${ }^{258}$ Incluso, algunos han llegado a plantear dicha autonomía, sin prestación, ${ }^{259} \mathrm{o}$ cuando la prestación principal se ha extinguido por alguna causa sobreviniente. ${ }^{260}$

Sin perjuicio de lo anotado, no todo es pacífico en relación a este punto. Existe la opinión que separándose de la tesis dominante, niega la autonomía de los deberes de protección. ${ }^{261}$ Bajo esta óptica, se entiende que el respeto tanto por el interés prestacional como por la persona de la contraparte se encuentran ya incluidas en el deber general de diligencia que debe inspirar el cumplimiento de la obligación. Por lo tanto, no resulta categórico sostener que el deber de protección es producto de un deber diverso al deber de comportamiento diligente que se encuentra consolidado en toda relación obligacional. ${ }^{262}$

\footnotetext{
${ }^{258}$ MeNGONI, Obbligazioni di...Ob. Cit., p. 369.

${ }^{259}$ En relación con una persona que por diversas razones, no ha tenido la obligación de realizar la prestación. VENOSTA, Francesco, "Profili della disciplina dei doveri di protezione" en Rivista di diritto civile, Anno LVII, № 6, Milano, 2011, pp. 850-851.

${ }^{260}$ En este sentido, otra hipótesis se produce cuando la obligación principal se extingue por una causa sobreviniente, pero sobrevive el deber de protección, si las circunstancias frente a la posibilidad de salvaguardar los intereses perseguidos recíprocamente por las partes, aun cuando el resultado de la prestación ya no posible. BRECCIA, Umberto, Diligenza e buona fede nell' attuazione del rapporto obligatorio, Milano, Vol. I. 1968, p.115.

${ }^{261}$ NATOLI, Ugo, "L'attuazione del rapporto obligatorio, I, II comportamento del creditore", en Trattato di diritto civile e commerciale, (Dir.) Cicu y Messineo, Milano, 1974, pp.114 y ss.; BIGLIAZZI GERI, Lina "Buona fede nel diritto civile", in Digesto delle discipline privatistiche, Sez. Civile, vol. II, Torino 1988, p. 171.; BIANCA, Cesare Massimo, "Dell'inaddempimento delle obbligazioni. Art. 1.218-1.229" en Commentario del Codice Civile a cura di Scialoja e Branca, Bologna-Roma, 1965, p. 35.; MAJelLo, Ugo, Custodia e deposito, Napoli 1958.

${ }^{262}$ Desde este punto de vista, la llamada obligación de protección o de seguridad, aparece en realidad como un momento esencial del contenido de la obligación, que se determina automáticamente en base a la naturaleza de la prestación y que se proyecta sobre el quantum de la diligencia necesaria para su ejecución. CABANILLAS SÁNCHEZ, Los deberes de ..." Ob. Cit., p. 144.
} 
Esta postura, niega la categoría de deber especial, ya que, la constitución relación obligatoria presupone que allí permanece firme el respeto de otros intereses (diligencia), toda vez que, para la satisfacción específica del interés del crédito es necesario precisamente que la prestación que no interfiera dañosamente con la esfera jurídica del acreedor. ${ }^{263}$

Al deudor, no se le exige simplemente un comportamiento de buena fe, sino un despliegue de actividad objetiva adecuada para evitar cualquier evento dañoso, es decir, un comportamiento diligente. Tal comportamiento forma parte integrante de la prestación debida sin que se deban constituir otros deberes del deudor. ${ }^{264}$

Una mirada más ecléctica la detenta Visintini, este hace hincapié y destaca el carácter instrumental de las obligaciones de seguridad con respecto a la ejecución de la prestación, en este sentido, observa que la relación contractual se enriquece en su estructura por la presencia de estas obligaciones de seguridad debido que constituye una oportunidad para salvaguardar los actos lesivos de uno $u$ otro contrayente en la relación. ${ }^{265}$

ii.- Justificación

${ }^{263}$ BIANCA, Ob. Cit., pp. 34-35.

${ }^{264}$ BIANCA, Ob. Cit., pp. 35-37.

${ }^{265}$ VISINTINI, Giovanna, "Inadempimento e mora del debitore", en Il códice Civile (dir.) Schlesinger, Milano, 1987, p. 29. 
Desde ya, debemos señalar que no resulta convincente, sino más bien del todo accidental, la visión que engloba el deber de protección en la diligencia que se deben los contratantes en la ejecución de la prestación. Ya que, aquello implica desconocer por completo la genuina esencia de la obligación de seguridad, por cuanto, -como hemos visto- esta responde a un interés (negativo) diverso al interés de la prestación misma (positivo).

En este sentido, ambas figuras que si bien son próximas, tienen originalidades y perfiles muy disímiles, que respetan y asumen roles propios en la relación obligacional. Cuando dos o más sujetos de derecho se encuentren en una relación obligatoria determinada, sus respectivas esferas jurídicas entran en contacto, más allá de la simple ejecución de los debido, esta zona común de inseguridad, se caracteriza por el efectivo peligro de que la actividad de una parte produzca daño tanto a la persona como al patrimonio del otro.

Al respecto Mancini nos advierte que para configurar el daño no puede en modo alguno concernir a la prestación, es decir, el criterio integrador de la buena fe contractual no opera ya sobre la relación central de la deuda y crédito, sino que establece frente a esta una especial relación (interés de protección autónomo), de la que derivan recíprocas situaciones pasivas, dirigidas a salvaguardar los intereses de seguridad que el contacto social pone en peligro. ${ }^{266}$

En igual dirección opina Franzoni, "este problema se puede resolver, una vez que se acepta que el artículo 1.375, (ejecución de

\footnotetext{
${ }^{266}$ MANCINI, Guiseppe Federico, La responsabilità contrattuale del prestatore di lavoro, Giuffrè, Milano, 1957, pp. 88-89.
} 
buena fe) no debe interpretarse como una norma en blanco, sino como una clausula general de la que surgen las obligaciones integrativas o limitaciones independientemente del ejercicio de la prestación". ${ }^{267}$

En España, Jordano Fraga ${ }^{268}$ considera que los deberes de protección derivados fundamentalmente de la buena fe, tienen un contenido autónomo respecto al deber de prestación, de modo que desde la perspectiva del deudor, estos deberes operan con independencia de que la prestación principal se haya cumplido. En este orden de ideas agrega: "Si el daño del acreedor ha existido, en un interés distinto al de la prestación, se opera la responsabilidad del deudor por la violación de estos deberes de protección aunque haya cumplido el deber de prestación, pues el diferente contenido de la responsabilidad en uno $u$ otro caso, permite que puedan funcionar independientemente uno de otro." 269

Para Echebarría Sáenz, ${ }^{270}$ los deberes de protección suponen la ventaja de configurar los deberes derivados de la buena fe como prestaciones autónomas respecto de las prestaciones principales, lo que permitiría una exigencia de responsabilidad, aun cuando la prestación principal se haya cumplido. ${ }^{271}$

\footnotetext{
${ }^{267}$ FranZONI, Massimo, Degli effetti del contratto, en II códice Civile Vol. 2 (dir.) Schlesinger, Milano, 1999. P. 204.

268 JoRdano Fraga, Francisco, La responsabilidad contractual, Civitas, Madrid, 1987. p, 141.

269 JORDANO FRAGA, La responsabilidad...", p,142.

${ }^{270}$ ECHEBARRÍA SÁENZ, Joseba, El contrato de franquicia: definición y conflictos en las relaciones internas, McGraw-Hill, Madrid, 1995, p, 363.

${ }^{271}$ Un ejemplo, lo presenta la adquisición de redes de franquicia competidoras por el franquiciador. Desde un punto de vista puramente sinalagmático no se produce ninguna afección a la prestación principal del negocio: la prestación reciproca es posible y se puede realizar sin mayores contratiempos. Sin embargo, de cara a las futuras prorrogas o renovaciones contractuales, no solo la posible reducción de áreas de exclusiva, sino el
} 
Zubiri de Salinas, por su pare recalca este carácter autónomo del instituto, señalando: "Que el deber de protección se deriva de la buena fe objetiva y tiene un contenido autónomo frente al deber de prestación. Con tal afirmación del deber de protección lo que pretendemos es ampliar el campo de la responsabilidad contractual, en virtud de la cual (el transportista) no responde exclusivamente del incumplimiento estricto del deber de prestación sino también de todas las consecuencias que según su naturaleza, sean conformes a la buena fe." 272

A modo de recapitulación, es posible señalar que la categoría de los deberes de protección, desde la posición deudora, comprende propiamente aquellos comportamientos cuya inobservancia lesiona o pone el peligro el interés de protección del acreedor, pero no perjudica además al interés positivo a la prestación, es decir, no excluye que la prestación principal sea ejecutada o pueda ser exactamente cumplida. Por lo tanto, los deberes de protección deben tener un contenido autónomo respecto al deber principal de prestación, y que concurren con este a la realización del fin total de la relación obligatoria.

simple reparto por el franquiciador del esfuerzo promocional entre los establecimientos franquiciados de ambas redes, denotaría un conflicto subyacente. A simple vista, dentro de la concepción convencional de responsabilidad contractual, se cumplen con todos los términos del negocio, puesto que al franquiciado de la red $\mathrm{A}$ le ha de ser indiferente si su franquiciador alcanza sus objetivos empresariales por medio de otros franquiciados pertenecientes a la red $B$. No obstante la alteración de la dinámica negocial, puede justificar el nacimiento de un deber de protección, pues el franquiciado no le es indiferente por medio de quien realiza su franquiciador su labor promocional. Franquiciador y franquiciado comparten en comunidad y durante el periodo contractual la clientela conexa a la marca, por lo que la obtención de rentas por el franquiciador mediante otro sistema comercial competidor, supone una reducción de la base retributiva del franquiciado. ECHEBARRía SÁENZ., Ob. Cit., p. 364.

${ }^{272}$ ZUBIRI DE SALINAS, Mercedes, La responsabilidad civil del transportista en el contrato de pasaje marítimo, Bosch, Barcelona, 1995, p. 319. 
De lo expuesto, podemos sostener que la inobservancia de los deberes de protección generan responsabilidad contractual, independientemente del cumplimiento efectivo del programa prestacional. Esta consecuencia, solo puede explicarse por medio del carácter autónomo que presentan los deberes de protección dentro de la relación obligatoria.

Esta simple afirmación, reporta a su vez importantes cambios en la forma de ver y entender en el ámbito de responsabilidad contractual, por cuanto, el cumplimiento puntual de las obligaciones contractuales no se presentaría como limitado a la mera realización de los deberes de prestación principal, sino que implicaría además que la actuación desarrollada no provocase perjuicios en las personas o bienes del acreedor, a esta consecuencia Castronovo la denomino responsabilidad relacional en sustitución de la responsabilidad contractual. ${ }^{273}$

b.- Contenido: ¿Obligación de resultado o de medios?

\section{i.- Antecedentes}

Se le concede el mérito al jurista Demogue, ${ }^{274}$ el haber inaugurado en la doctrina, la distinción entre obligaciones de medios y

\footnotetext{
${ }^{273}$ Castronovo, Ob. Cit. pp. 61 y ss.

${ }^{274}$ DEMOGUE, Rene, Traité des obligations en général, sources des obligations, t, I., Librairie Rousseau \& Cie, París, 1925.
} 
de resultado. ${ }^{275}$ Tal distinción, es hasta hoy una cuestión bastante debatida en la dogmática, son numerosos los problemas que surgen al tratar de configurar el régimen jurídico de ambos tipos de obligaciones. ${ }^{276}$

Para diferenciar las obligaciones de medios y de resultado hay que tener muy en cuenta el objeto de la obligación. Cuando la obligación es de medios, el deudor esta obligado a desarrollar a favor del acreedor una determinada conducta, encaminada a alcanzar el resultado esperado por el acreedor, que satisface su interés primario. Sin embargo, debido al carácter aleatorio o incierto de dicho resultado, el deudor no garantiza su obtención, y cumple si actuó con la diligencia debida para alcanzarlo. Por su parte si la obligación es de resultado, el deudor garantiza la obtención del resultado que constituye el interés primario del acreedor. ${ }^{277}$

\footnotetext{
${ }^{275}$ Sin embargo, hay autores que consideran indicios históricos de tal distinción. Mazeaud, señala que es un grave error no buscar en el Derecho romano la distinción entre la obligación general de prudencia y la obligación determinada. Algunos contratos son arriesgados para el acreedor, especialmente aquellos en que un cuerpo cierto es entregado por una de las partes a la otra, estando esta ultima obligada a su restitución. Queriendo proteger de una manera eficaz al acreedor, los jurisconsultos romanos de la época clásica analizaron el contenido de la obligación del deudor, y afirmaron que el deudor promete un acto determinado: la restitución. Si el deudor no restituye, su responsabilidad surge por este solo hecho, a menos que pruebe el caso fortuito. No hay que investigar si actuó o no como buen padre de familia. En otros contratos, en cambio, la obligación del deudor no esta determinada, a los ojos de los jurisconsultos, de forma tan exacta, ya que el deudor no promete un hecho preciso, un resultado, sino un esfuerzo constante y sincero, un obrar de buena fe, una obligación de las que Gayo designa de fides et diligentia praestare. En consecuencia, en estos contratos, a diferencia de los anteriormente citados, para que el deudor pueda ser condenado es necesario probar que no ha sido diligente: un examen de su conducta es preciso para demostrar el incumplimiento y para ello probar su culpa. MAZEAUD, Henri, "Essait et classification des obligations: Obligactions contractuelles et extra-contractuelles, obligations determinées et obligations générale de prudence et diligence" en Revue Trimestrielle de Droit Civil, Nº 28, París, 1935.

${ }^{276}$ Un ejemplo de aquello es la disparidad en la terminología utilizada, (obligaciones de actividad, de medios o de diligencia y obligaciones de resultado o determinada). CABANILLAS SÁNCHEZ, Antonio, Las obligaciones de actividad y de resultado, Bosch, Barcelona, 1993, p. 9.

${ }^{277}$ CABANILLAS SÁNCHEZ, Antonio, Las obligaciones de....", p. 9.
} 
Dicho de otro modo, la distinción de la que hablamos se establece básicamente por la diferente manera de entender el objeto de la obligación, es decir, por la diversa manera de definir el contenido de la prestación del deudor, lo que se debe entender debido por este y lo que el acreedor puede legítimamente exigirle como contenido de su derecho de crédito.

Así, Mengoni ${ }^{278}$ señala que tal distinción se instaura, a partir de la inclusión o no en la prestación del deudor, del logro o realización de aquel interés primario del acreedor que subyace en la constitución del vínculo obligatorio. Cuando se incluye, nos hallamos ante una prestación de resultado, cuando no, ante una de medios o de simple actividad. $^{279}$

\footnotetext{
${ }^{278}$ MengonI, Obbligazioni di risultato...." Ob. Cit. pp.185 y ss.

${ }^{279}$ En el primer caso (obligación de resultado) el deudor no se obliga solamente a desplegar una simple actividad diligente con vistas a la consecución de un determinado resultado, sino que es precisamente el logro de este concreto resultado el que se constituye en contenido de la prestación del deudor. En cambio, cuando se trata de prestaciones de actividad o de medios, el contenido de la prestación del deudor, se agota en el simple despliegue o desarrollo de una actividad o conducta diligente, sin que se integre en el contenido de la prestación del deudor, el logro o consecución del fin al que tal actividad o conducta esta enderezada. Un ejemplo claro de una obligación de resultado es la del "transportista" o la del "contratista de obra": ni uno ni otro puede pretender haber cumplido su prestación, sino cuando realizan el concreto fin o resultado debido: la traslación, en el espacio y sin daño, de las cosas o personas transportadas al punto de destino; la realización de la construcción o reparación comprometidas. No basta aquí, a los efectos del cumplimiento, el desarrollo de una actividad diligente, si esta no se ha traducido en el logro efectivo del concreto resultado debido. En cambio, son normalmente obligaciones de actividad o de medios, las del médico, del abogado o del mandatario y gestor de negocios. El médico cumple su obligación, cuando desarrolla o despliega el conjunto de curas y atenciones, en las fases diagnosticas, terapéuticas y recuperatoria, que son exigibles de un profesional o especialista normal, en las circunstancias del caso. Luego, se sigue que habiendo desplegado esas curas y atenciones, el medico cumple pues es éste el contenido de su prestación, aquello a lo que se obliga, aunque el paciente no haya sanado, no se recupere en su salud, no obtenga la curación apetecida. Es le conjunto de curas y procedimientos técnicamente correctos, lo que el médico debe, y no la curación o sanación. Lo mismo puede decirse del abogado o del mandatario o gestor de negocios: el abogado cumple su obligación si, ante una determinada causa judicial, despliega una actividad ética y profesionalmente correcta, aunque el fallo judicial sea adverso a los intereses de su patrocinado; , igualmente el mandatario o gestor que administran intereses ajenos, cumplen su respectiva obligación si han desarrollado una actividad gestora diligente, aunque el resultado final de su gestión haya sido perjudicial a los intereses del
} 
El criterio utilizado para determinar cuando una obligación es de medios o de resultado, será naturalmente la voluntad de las partes. No obstante, dicho criterio no será, sino solo el comienzo de las dificultades, por cuanto, en el curso normal de la vida jurídica, con frecuencia las partes no son muy rigurosas en la determinación exacta de sus intereses.

Por lo que, para precisar dicha calificación, será necesario efectuar un análisis a posteriori de dichas voluntades, verificando en cada caso, cómo se ha definido en una concreta obligación el justo contenido de la prestación debitoria, ya sea, por sus partes o por la ley. Son diversos los criterios que se propugnan para resolver el problema que deriva de que no se conste claramente en el contrato el carácter de la obligación asumida por el deudor, o sea, saber si la obligación es de medios o de resultado. ${ }^{280}$

Bajo este respecto habrá que atender a la situación de las partes, al carácter aleatorio del resultado, al papel activo o pasivo del acreedor en el cumplimiento entre otros. ${ }^{281}$

mandante o del dominus negotii. Véase, JORDANo FRAGA, Francisco, "Obligaciones de medios y de resultado", en Anuario de derecho civil, Vol., 44 № 1, 1991, pp. 8-9.

${ }^{280}$ CABANILLAS SÁNCHEZ, Las obligaciones de....", p. 10.

${ }^{281}$ Un ejemplo de ello: a) Habrá que estar ante todo a la voluntad de la partes de la obligación, a como ha definido esta la prestación, lo debido por el deudor: no solo la voluntad expresa, sino también la tácita; b) A la propia naturaleza intrínseca de lo debido, y a lo que la buena fe exige, a la vista de la primera del deudor para cumplir; c) La aleatoriedad de la prestación, no debe considerarse en principio incluidos en el contenido de la prestación del deudor un resultado o fin cuya realización o logro efectivo no este en la mano de deudor, sino dependan en gran medida otros factores ajenos a su control; d) A la equidad, como aplicación específica de la buena fe como criterio de una justa reciprocidad entre las partes contractuales. Véase, JoRDANo FraGA, “Obligaciones de...” Ob. Cit., p.10. 
La distinción entre las obligaciones de medios y de resultado tiene una aplicación general el ámbito obligacional, y su relevancia resulta vital en el plano de su cumplimiento. Pues la realización de la actividad diligente basta para que la obligación de medios se considere cumplida, aunque el interés primario del acreedor no se satisfaga. Por el contrario, el cumplimiento de la obligación de resultado requiere, la plena satisfacción del interés del acreedor, no siendo suficiente para estos efectos la mera conducta del deudor encaminada a satisfacerlo.

Una problemática interesante que presenta esta distinción entre obligaciones de medios y de resultado, es en el campo de la prueba. Esta se traduce en que, a consecuencia del distinto contenido de la prestación, el cumplimento en uno u otro caso conllevan significados diversos a la hora de entender el hecho del incumplimiento.

Tratándose de una obligación de resultado, basta la prueba de la falta o defectuosidad del opus debido, mientras que, si la obligación es de medios, hay que demostrar la falta total de la actividad debida, es decir, el obrar negligente. En el terreno que nos ocupa, tal circunstancia no es menor, dado que si entendemos el deber de protección como una obligación de resultado, dicho resultado es el interés tutelado, por lo que es determinado, es decir, el deudor se compromete a que no ocurra ningún hecho dañoso imputable a él que lesione a su acreedor, de lo que se sigue que el deudor solo podrá librarse probando caso fortuito o causa ajena.

Muy por el contrario, si entendemos el deber de protección como una obligación de medios, la víctima deberá demostrar que el 
incumplimiento se debió a la negligencia de su deudor, desnaturalizando tempranamente la esencia del deber de protección.

ii.- Implicancia en el deber de protección

En lo tocante a nuestro objeto de estudio, como observa Denis Mazeaud, resulta ser un terreno predilecto para la famosa distinción entre las obligaciones de medios y de resultado. ${ }^{282}$

Dice al respecto Bellissent: "Las evoluciones respectivas de las nociones de obligación de seguridad por un lado $y$, obligaciones de medios y resultado por el otro, están estrechamente ligadas, pudiéndose inclusive hablar de una verdadera comunidad de intereses (...), y esa estrechez relacional que mantienen las dos figuras va más allá del estado filial de la primera por sobre la segunda. Efectivamente, un rápido examen histórico revela cuanto el desarrollo de cada una entre ellas ha necesitado el refuerzo de la otra. En otros términos, si la teoría de las obligaciones contractuales de seguridad parece haber favorecido innegablemente la emergencia de la clasificación en obligación de medios y de resultado, esta última ha tenido por principal efecto el florecimiento del concepto de seguridad contractual. ${ }^{2283}$.

Aunque en la actualidad la tesis dominante da por descontado que la calificación de obligación resultado sea la única interpretación

\footnotetext{
${ }^{282}$ MAZEAUD, "Le régime de...," Ob. Cit., p. 28

283 Bellissent, Ob. Cit., p. 313.
} 
concebible, tratándose de obligaciones contractuales de seguridad, por cuanto, esta última resulta ser la única opción que permite conservar incólume la marcada utilidad en la maniobra de contractualización emprendida por la jurisprudencia alemana y francesa de principios del siglo $X X{ }^{284}$

No por ello ha dejado de ser una cuestión inmensamente debatida en doctrina, siendo objeto de un dilatado peregrinaje y de una constante fluctuación tanto de la jurisprudencia como de la doctrina. Ya autores como Henry y León Mazeaud y André Tunc, han señalado que el deudor de seguridad puede haberse obligado a realizar lo que manda la prudencia y la diligencia para evitar los accidentes. Por lo que estamos para estos autores frente a una obligación general de prudencia (de medios). ${ }^{285}$

En este sentido se afirma que cuando los tribunales franceses han experimentado la necesidad de asegurar una protección eficaz de la víctima, han acudido a la obligación determinada de seguridad (de

\footnotetext{
${ }^{284}$ REMY, La responsabilité ....", Ob. Cit., p. 339; GARCIA VALDECASAS, Guillermo, "El problema de la acumulación de la responsabilidad contractual y delictual en el derecho español", en Revista Derecho. Privado., t. XLVI, 1962, p. 839; JosseRAND, Louis, Derecho civil. Teoría general de las obligaciones, t. II, vol. I, Revisado y completado por BRUN, Andre, trad. de Santiago Cunchillos y Manterola, (ed.) Santiago Sentis Melendo, Ejea, Buenos. Aires, 1950, p. 377; ORTI VAlLEJo, Antonio, "La cuestión de la concurrencia de responsabilidad contractual y extracontractual en los daños por servicios" en La responsabilidad civil por daños causados por servicios defectuosos: estudio de la responsabilidad civil por servicios susceptibles de provocar daños a la salud y seguridad de las personas (Dir.) - ORTI VAllejos, Antonio, García GARnicA, María del Carmen, Thomson-Aranzadi, Navarra, 2006, p. 48.; BELLISSENT, Jean, Contribution à l'analyse de la distinction des obligations de moyens et des résultat. À propos de l'évolution des ordres de responsabilité civile, Librairie Générale de Droit et de Jurisprudence, Paris, 2001, p. 318; LE Tourneau, Ob. Cit., p. 667; JourdaIn, Patrice, "L'obligation de sécurité. À propos de quelques arrêt récents", en Gazette du Palais, 1993, p. 1.214.

${ }^{285}$ MAZEAUD, Henri y León, TUNC, Andre, Traité théorique et practique de la responsabilité civile: délictuelle et contractuelle. Lib. du Recueil Sirey, Paris, Vol. I, 1934, pp. 190-191; también en: MAZEAUD, Henry y León, TUNC, Andre, Tratado teórico y práctico de la responsabilidad civil, delictual y contractual, $\mathrm{t}$ I, vol. I, trad. por Luis Alcalá Zamora y Castillo, Ejea, Buenos. Aires., 1977, p. 277 y ss..
} 
resultado), así las obligación de seguridad de resultado ha sido descubierta en muchos contratos, al menos en todos aquellos en los que aparece necesario proteger a la víctima relvándolas de probar la culpa. En los restantes contratos, la jurisprudencia se contenta con la afirmación de la existencia de una obligación de seguridad general de prudencia y diligencia (de medios). ${ }^{286-287}$

Le Torneau ${ }^{288}$ sostiene que al principio, la obligación de seguridad fue entendida como una obligación de resultado: devolver al viajero sano y salvo a destino, lo cual presentaba una ventaja considerable para el acreedor. Si este llegaba herido al destino, le bastaba con probar la existencia de las lesiones. El transportista solo podía exonerarse estableciendo un suceso de fuerza mayor, el hecho de un tercero o de la víctima.

Pero, poco a poco, la jurisprudencia francesa extendió la noción a un gran número de contratos, restringiendo su alcance en la medida en que, lo más a menudo, ella considera que la obligación de seguridad solo es de medios. Por lo que el acreedor debe probar la culpa de la otra parte. De esta manera acontece frecuentemente que el pretendido favor que supone la obligación de seguridad se vuelve contra su beneficiario, pues, a falta de esta consecuencia del contrato,

\footnotetext{
${ }^{286}$ CABANILLAS SÁNCHEZ, Los deberes de protección..."pp. 196-197

${ }^{287}$ Este fenómeno lo sintetiza Viney, al decir que para calificar la obligación de seguridad como de resultado, los tribunales exigen que la actividad desplegada por el deudor exponga al acreedor a un verdadero peligro contra el cual este último no tiene forma de defenderse por haber "abdicado su libertad de movimiento" confiando su seguridad a otro. Cuando estas condiciones no se reúnen la obligación de seguridad reviste el carácter de un deber de medios. VINEY Genevieve - JOURDAIN, Patrice, "Les conditions de la responsabilité", en Traité de Droit Civil, Ob. Cit., p. 553;

${ }^{288}$ Le TOURNEAU, Philippe, "Contrats et obligations. Classification des obligations. La distinction des obligations de moyens et des obligations de résultt et l'obligation de sécurité" en Juris-Classeur Civil, art. 1091 à 1145, Paris, 1996, nº 13.
} 
hubiese podido poner en juego la responsabilidad delictual de pleno derecho del artículo 1384.1 C.c. francés.

Así, la idea de obligación de seguridad-medios, animada por un dinamismo sorprendente, es introducida en los contratos más diversos, como ser la obligación de seguridad que pesa sobre los hoteleros o dueños de establecimientos de comidas, empresas de espectáculos, agencias de viajes de vacaciones, jardines de infantes, escuelas de conducción de vehículos, etc. ${ }^{289}$

Como consecuencia de lo expuesto, alega Bénabent, la jurisprudencia es a menudo incierta y fluctuante, es preciso constatar que reina el mayor de los desordenes sobre esta clasificación, ninguna verdadera razón lógica permite explicar la repartición que lleva a cabo la jurisprudencia y esta repartición no es ella misma constante, ya que, una misma obligación puede ser, según dos periodos, de medios o de resultado. ${ }^{290}$

\footnotetext{
${ }^{289}$ Hocquet-BeRg, Sophie, Obligation de moyens ou obligation de résultat? ... Ob. Cit., p. 268.; BRUN, Philippe, "Les hypothèses les plus variées" en Responsabilité civile extracontractuelle, Litec, Paris, 2005, p. 73.; VeaUX-FournerIE, Paulette - VEAUX, Daniel, L'obligation de sécurité dans la vente, Litec, Paris, 2002, pp. 4 y ss.; BLOCH, Cyril, L'obligation contractuelle de sécurité, Presses Universitaires d'Aix-Marseille, 2002, pp. 15 y SS.; FAURE-ABBAD, Marianne Le fait générateur de la responsabilité contractuelle. Contribution à la théorie de l'inexécution du contrat, Librairie Générale de Droit et de Jurisprudence, Paris, 2003, p. 466.

${ }^{290}$ Se conocen ciertos tipos de obligaciones que han cambiado de categoría varias veces, por ejemplo: la obligación de seguridad de quienes explotan un telesquí, después de haber sido de medios se transformó en de resultados en 1968. Después volvió a ser de medios en 1986, luego otra vez de resultado en 1995. De igual modo, la obligación de seguridad del transportista de viajeros a menudo ha fluctuado demasiado sutilmente. De manera general, las obligaciones de seguridad dan lugar a un gran desorden en cuanto a su clasificación. La naturaleza de la obligación del mecánico de autos por ejemplo fluctúa, o el que recibe un caballo para entrenamiento, en cuanto a su seguridad no debe más que una obligación de medios pero si lo recibe en pensión (para alimentarlo) debe la obligación de resultado atenuada del depositario. El empresario de espectáculos debe una obligación solamente de medios, pero salvo circunstancias particulares. Los tribunales son sensibles al rol activo o pasivo de la víctima, pero éste no es el único elemento. Se llega a menudo a una casuística incierta y la sola lectura de las revistas de jurisprudencia permite conocer en cada caso particular la solución en vigencia. Véase, BÉNABENT, Alain, Droit civil. Les
} 
Jourdain, ${ }^{291}$ subraya que el adjuntar ficticiamente obligaciones que ni las partes ni la ley han previsto expresamente mediante el artilugio técnico del deber de seguridad tiene por efecto extender arbitraria y abusivamente el dominio de la responsabilidad contractual, extensión realizada a menudo en perjuicio de las víctimas. Ciertamente, el haber multiplicado esta obligación de seguridad a contratos donde ella no tenía nada que hacer, atentó la economía del vínculo negocial, es una injusticia, acota Larroumet. ${ }^{292}$

La concepción de la obligación de seguridad de medios, resulta francamente alarmante, por cuanto expone a la víctima en una situación delicada y priva a la obligación de seguridad de toda su legitimidad y utilidad. En este sentido, la víctima (contratante) deberá probar la imprudencia del deudor para perseguir su responsabilidad contractual. De lo que se sigue, que la obligación de seguridad de medios es contractual por mero azar, ya que, el objeto del contrato que supuestamente la contiene esta muy alejado de la idea de seguridad o protección.

En resumidas cuentas, podemos sostener que un reconocimiento de una obligación de seguridad de medios, en nada añade protección a la víctima, si no todo lo contrario, por cuanto, si la finalidad es la introducción en el contrato de una obligación que brinde

obligations, 9a éd., Librairie Générale de Droit et de Jurisprudence-Montchrestien, Paris, 2003, p. 274 y ss.

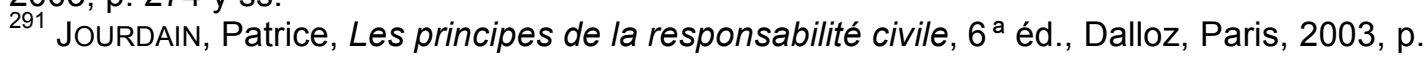
32 ;

292 LARROUMET, Christian, "Pour la responsabilité contractuelle", en Études offertes à Pierre Catala. Le Droit privé français à la fin du XX siècle, Litec, Paris, 2001, p. 543 y ss. 
protección a las partes contratantes, dicho objetivo solo se alcanza cuando la obligación de protección es de resultado.

Por ello se ha sostenido que la obligación de seguridad debe ser siempre una obligación de resultado, en esta dirección se ha inclinado la jurisprudencia, vislumbrando con ello un retorno a la posición original del instituto. ${ }^{293}$ En este mismo sentido expone Benatti: "Prescindiendo de toda evaluación crítica sobre la exactitud de este enfoque en orden a la carga de la prueba, es oportuno evidenciar que, si se le impone al damnificado la prueba de la culpa, se debilita la razón práctica que había inducido a la jurisprudencia a la elaboración de las obligations de sécurité"294

El deber de protección o obligación de seguridad, solo tiene sentido si se concibe de resultado, como había sido percibido en su origen. De ahí que la obligación de seguridad de medios tiene un fin perverso, por cuanto, solo operaría en desmedro de la víctima, a la cual se le veda en la mayor de las veces, de contar con un marco más favorable, como sería la esfera extracontractual, dado que el ordenamiento francés no acepta la teoría de la acumulación de responsabilidades.

\footnotetext{
${ }^{293}$ En las sentencias de la Cours de Cassation, de 7 de marzo de 1989, 10 de enero de 1990, 22 de marzo de 1991, 4 de noviembre de 1992, y 17 de enero de 1995, se observa una favorable inclinación hacia la exclusión de la obligación de seguridad de medios en pos de la obligación de resultado. Véase, Reveu Trimestrielle de Droit Civil (RTDC), RTDC 1989, p 550; RTDC, 1990, p. 483; RTDC 1991, p. 758; RTDC 1993, p. 367; RTDC 1995, p. 634.

${ }^{294}$ BenAtTI, Ob. Cit., pp. 1345 y ss.
} 
iii.- Deber de protección: Genuina obligación de resultado

Más allá de evidentes criticas y el marcado retroceso que ha experimentado las obligaciones de seguridad de medios en el ordenamiento jurídico, ${ }^{295}$ resulta indiscutible el hecho que cuando la seguridad o protección es el objeto de la obligación, no puede admitirse un termino medio, toda vez, que su ejecución no es susceptible de división jurídica, o se la garantiza mediante un típico deber de fines, o lo que está en juego es otra cosa, una obligación de prudencia y diligencia.

De allí que, o bien la obligación de seguridad es de resultado o ella no es contractual. ${ }^{296}$ Es menester recordar que la aparición de la obligación de seguridad tuvo por finalidad mejorar la situación del damnificado en el campo probatorio, por ende, sí la entendemos como una obligación de medios, la víctima pasa a ser perjudicada por que siempre tendrá que demostrar la culpa del deudor y, de esta manera, el remedio se convierte en veneno. ${ }^{297}$

¿Puede hablarse entonces de un genuino crédito a la seguridad, cuando la situación del acreedor sería más favorable sí no lo tuviera? Como hemos señalado anteriormente, un reconocimiento

\footnotetext{
${ }^{295}$ Se asiste francamente a un proceso de desecación de la categoría obligación de seguridad-medios, sea tutelando el evento dañoso bajo la orbita delictiva (considerando implícita la obligación de prudencia y diligencia en la prestación principal) o reencaminando la originaria obligación de seguridad-resultado. Véase, JouRDAIN, Patrice, "Responsabilité civile", en Reveu Trimestrielle de Droit Civil, 1993, pp. 365 y ss.

${ }^{296}$ JOURDAIN, "L'obligation de sécurité...." Ob. Cit., pp. 1.171 y ss.; LAPOYADE DESCHAMPS, Ob. Cit., p. 128; PRADEL, Ob. Cit., p. 322; BRUn, Ob. Cit., p. 77.

${ }^{297}$ FAURE-ABBAD, Ob. Cit., p. 466; CABANILLAS SÁNCHEZ, Los deberes de protección ....", Ob. Cit., p. 179.
} 
de la obligación de seguridad de medios no agrega en nada a la protección de la víctima, sino todo lo contrario, la empobrece.

Al respecto subraya Jourdain: "Las denominadas obligaciones de seguridad-medios han sido puesta en tela de juicio, tanto en razón de su propio objeto como por el efecto perverso de la exclusión de normas delictivas." 298 Por su parte, Lambert Faivre es categórica al señalar que: "La obligación de seguridad es por naturaleza una obligación determinada," ${ }^{299}$ cuestión compartida por Le Tourneau, para quien: "La obligación contractual de seguridad siempre debería ser un deber de resultados."

En la actualidad, son numerosos los autores que proclaman firmemente el carácter unívoco de la obligación de seguridad, cuya única ejecución conveniente debería consistir en la obtención del resultado que constituye la restitución integral e inalterada de la persona del co-contratante. ${ }^{301}$

Nos inclinamos, por conservar el significado originario de la obligación de seguridad como deber de resultado, rechazando la modalidad de obligación de medios. Sostener lo contario, significaría negar anticipadamente su carácter protector.

En este sentido, el deber de protección u obligación de seguridad pertenece por naturaleza a la categoría de las obligaciones

\footnotetext{
298 JOURDAIN, “Le fondament de l'obligation de sécurité... “, Ob. Cit., pp. 22 y ss.

299 LAMBERT FAIVRE, Yvonne, Fondement et régime de l'obligation de sécurite, Recueil Dalloz., Paris, 1994, p. 84.

300 Le TourneAu, Philippe, Droit de la responsabilité et ... Ob. Cit., p. 667.

${ }^{301}$ Bellissent, Ob. Cit., p. 317; Le Tourneau, Ob. Cit., p. 666.; BenatTI, Ob. Cit., p. 1342 y ss.; ORTI VAllejo, Ob. Cit.,p. 48.
} 
de resultado, pues, siendo la obligación de seguridad concebida en interés exclusivo de las víctimas, su reconocimiento solo se justifica, o sea, su objetivo solo se alcanza, cuando es de resultado.

\section{V.- ÁmBITO de APLICACIÓN: PLANTEAMIENTO dEL PROBLEMA}

A esta alturas, podemos hacer fe, sin temor alguno de la legítima existencia de los deberes de protección como una parte integrante y funcional de la relación obligacional moderna.

En esta dirección, hemos explorado sus fronteras y descrito sus notas más principales. En tal orden de cosas, podemos ratificar concluyentemente que los deberes de protección tienen por especial objeto evitar que sean lesionados intereses personales 0 patrimoniales de la contraparte, sobre este aspecto nos ilustra Larenz: "Los deberes de protección surgen cuando una parte en el curso del contacto expone sus bienes, especialmente la salud y la propiedad, a la posibilidad de injerencia de otra. ${ }^{1302}$

Tal abstracción presupone la idea de que un sujeto que entra en contacto con otro, mediante una relación obligatoria, expone su propia esfera jurídica a riesgos que de otra manera no le afectaría, es decir, entra en una especifica zona de peligro, determinada por la posibilidad de la actividad de la otra parte, conexa al desarrollo de la relación obligacional.

302 LARENZ, Ob. Cit., p. 110. 
Luego, en el evento que, por la injerencia o la actividad de la contraparte se produzca un daño a la persona o patrimonio del acreedor, la consecuencia propia de aquello será, -como sabemos- la aplicación de las reglas de la responsabilidad contractual a daños, que si no mediaran estos deberes en comento, serían reparados por la orbita delictual.

Dada la máxima anterior, nace la lógica inquietud de saber, si tal contractualización abarca todo tipo de daños entre las partes vinculas por la relación obligacional. Dicho con otras palabras, ¿Solo basta la presencia de un contrato para que los daños ocasionados entre las partes, distintos al interés de prestación, sean indemnizados por la responsabilidad contractual?

Debemos tener presente, que resulta perfectamente posible que entre las partes de una relación obligatoria puedan darse supuestos de responsabilidad extracontractual, en la medida que tales daños resulten completamente ajenos al contenido obligacional que los une..$^{303}$

Esta circunstancia, ha significado una creciente aprensión en la doctrina relativo al retroceso o vaciamiento de la responsabilidad extracontractual en las relaciones entre acreedor $y$ deudor al reconducir al terreno contractual cualquier daño que el acreedor experimente en el curso del cumplimiento lato sensu de la obligación. ${ }^{304}$ En esta dirección apunta Jourdain al señalar: "La

\footnotetext{
303 YZqUierdo TolsadA, Mariano, Sistema de responsabilidad civil, contractual y extracontractual, Dykinson, Madrid, 2001, p. 472.; PANTALEÓn, Fernando, Comentario del código civil, t., II., Ministerio de Justicia, Madrid, 1991, p. 1977

304 JORDANO FRAGA, Francisco, La responsabilidad del deudor por los auxiliares que utiliza en el cumplimiento, Civitas, Madrid, 1994, p. 252.
} 
obligación de seguridad es la mejor y sin duda la primera ilustración del fenómeno conocido como reforzamiento jurisprudencial del contenido del contrato, lo que Josserand llamaba forçage du contenu du contract. ${ }^{\prime 305}$

Este fenómeno conocido también como "inflación obligacional", ha sido denunciado tanto en la doctrina francesa ${ }^{306}$ como en italiana. ${ }^{307}$ Tal noción, considera, -por lo menos en sus inicios- el traspaso de la seguridad al orden contractual, lo que en atención al contexto existente a comienzos de siglo XX, conllevaba de por sí, una ventaja evidente al permitir un desvío sistemático de las reglas delictivas que tantas dificultades acarreaban a la víctimas. ${ }^{308}$ Así las cosas, el contrato debía soportar o tolerar la carga de todas las

305 JOURDAIN, "Le fondement del'obligation....", Ob. Cit., p. 22.

${ }^{306}$ Remy se refiere a ella como "contractualisation des dommages", Véase, REMY, Ob. Cit., p. 339.

${ }^{307}$ Di Majo, la define como "contrattualizzazione della responsabilitá aquiliana", DI MAJO, Ob. Cit., p. 22.; Por su parte Breccia, la precisa como "contrattualizzazione deo danni alla persona", BRECCIA, Ob. Cit., p. 673.

${ }^{308}$ En efecto, siguiendo a Guillermo García Valdecasas, si se excluye radicalmente de la esfera del contrato la responsabilidad delictiva, resulta que muchos daños que pueden causarse las partes con ocasión del contrato o en el curso de su ejecución, pero que no suponen el incumplimiento del mismo quedarían sin posibilidad de reparación. Para evitar esta anomalía la jurisprudencia francesa acude a una ficción: la de considerar implícita, en ciertos contratos, una obligación general de seguridad hacia las personas y los bienes de la otra parte. De esta manera los daños causados al otro contratante, con ocasión de la relación contractual, aparecen como el efecto del incumplimiento de una obligación contractual de seguridad asumida tácita y necesariamente al celebrar el contrato. Por este procedimiento los tribunales franceses han descubierto en diversos tipos de contrato la existencia de semejante obligación de seguridad: la obligación del transportista de personas de conducir al viajero sano y salvo a su destino, obligación de los dueños de parques de atracciones, de asegurar la integridad física de los usuarios, obligación de los hoteleros de garantizar a sus huéspedes una seguridad absoluta, etc. El procedimiento es, sin duda, muy forzado, pues se presume en las partes la voluntad de contraer una obligación que la mayor parte de las veces ni siquiera pasó por su imaginación. Pero ello es consecuencia de eliminar la responsabilidad delictiva del ámbito de los contratos. Véase, GARCÍA VALDECASAS, Guillermo, "El problema de la acumulación de la responsabilidad contractual y delictual en el derecho español...Ob. Cit., p. 839. 
situaciones perjudiciales independientemente de las circunstancias de hecho que las hayan originado. ${ }^{309}$

Bajo este escenario, el deber de protección ha sido en parte víctima de su propio éxito, experimentando una extensión extraordinaria, incontrolada e imprevisible. Se hace latente entonces, la necesidad de contar con directrices eficaces, mediantes las cuales resulte justificado y correcto aplicar las reglas de la responsabilidad contractual a los daños provenientes de la inobservancia de un deber de protección, excluyendo así el riesgo que dicha expansión de las reglas contractuales al damnificado, puedan significar un vaciamiento impropio de la responsabilidad extracontractual.

\section{1.- NOCIONES PRELIMINARES}

Razón tenía Jordano Fraga al afirmar que resulta de máximo interés y primordial, contar con un criterio seguro, que permita delimitar hasta donde puede llegar la penetración del régimen de la responsabilidad contractual en dominios, en principios ajenos, y hasta donde, consiguientemente, el retroceso de la responsabilidad extracontractual respecto de ámbitos que, sin aquella penetración, serían de su exclusiva incumbencia. ${ }^{310}$

\footnotetext{
${ }^{309}$ REMY, Ob. Cit., p. 323 y ss.; MARTINE, Edmond, L'option entre la responsabilité contractuelle et la responsabilité délictuelle, Librairie Générale de Droit et de Jurisprudence, Paris, 1957, p. 37.

310 JORDANO FRAGA, La responsabilidad del...”.p. 244.
} 
Como sabemos, no cualquier daño producido entre las partes de la relación obligatoria desencadena en la aplicación de la responsabilidad contractual, sino que, para la aplicación de tales reglas contractuales procedan, dicho daño debe provenir de la infracción o incumplimiento de una obligación entendida en términos técnicos.

Un ejemplo claro de aquello, lo constituye la doctrina asentada desde mediados de los años 80 por el Tribunal Supremo español, que entiende que un daño es contractual cuando acontece dentro de la rigurosa órbita de lo pactado y como preciso desarrollo del contenido negocial. ${ }^{311}$

No obstante, es necesario tener presente, que esta visión tradicional debe ser observada hoy, bajo nuevos enfoques $y$ fundamentos, en pos de efectuar un oportuno seguimiento al estrato de realidad que se ostenta regular. Por cuanto, como hemos ya tenido la ocasión de señalar, la inclusión de los deberes de protección en el marco de la teoría general de las obligaciones, origina una notoria alteración de la óptica tradicional del fenómeno obligacional, tanto en

\footnotetext{
${ }^{311}$ En opinión de Yzquierdo Tolsada, el inicio de esta doctrina jurisprudencial se encuentra en la STS de 9 de marzo de 1983. Se trataba de un juicio de indemnización de daños y perjuicios sufridos a raíz del fallecimiento de un obrero en un accidente laboral, producido por la falta de medidas de seguridad del empresario para el que trabajaba, cuestión que para el citado autor "no deja de ser una violación netamente contractual". El Tribunal Supremo, no obstante, concedió la indemnización solicitada sobre la base de las reglas de la responsabilidad extracontractual, afirmando que "no es bastante que haya un contrato entre las partes para que la responsabilidad contractual opere necesariamente con exclusión de la aquiliana, sino que se requiere para que ello suceda la realización de un hecho dentro de la rigurosa órbita de lo pactado y como desarrollo del contenido negocial". YZQUIERDO TOLSADA, Mariano, Sistema de responsabilidad civil, contractual y extracontractual, ... Ob. Cit., p. 98.; También en DE ÁNGEL YAGÜEZ, Ricardo, "Puesto que ocupa el Derecho de daños en el Derecho de obligaciones", en Revista Estudios de Deusto, Bilbao, 1995, pp. 32-33.
} 
lo relativo a su contenido como sobre todo en lo tocante al concepto de incumplimiento.

Esta perspectiva nos impulsa a abandonar el significado clásico de incumplimiento contractual, en orden a entender este, solo referido a la infracción de una obligación en sentido técnico, por un concepto mucho más amplio que importe la relación existente entre el interés primario a la prestación con los otros interés secundarios que cohabitan en la relación obligacional.

Por ende, el incumplimiento de la relación obligacional debe comprender, tanto al deber de prestación principal como a los deberes de prestación secundarios o accesorios. La responsabilidad llamada contractual, ya no, es más la responsabilidad por incumplimiento sino responsabilidad por violación de la relación obligacional entendida en su integridad. ${ }^{312}$

Recordaremos, que en la concepción originaria, los schutzpflichten de Stoll, consideraba la aplicación de la responsabilidad contractual a todo daño sufrido por las partes con ocasión o bajo la vigencia del contrato, sin importar el origen de esos daños. Esta noción radical, se explica en parte por la génesis precontractual de los deberes de protección en Alemania.

Posteriormente, gran parte de los autores hacen una distinción entre daños causados por el deudor en el cumplimiento y con ocasión del cumplimiento, para aplicar la responsabilidad contractual solo a los primeros. Un ejemplo de lo anterior, lo expone Larenz: El maestro

${ }^{312}$ Castronovo, Ob. Cit., p. 61. 
pintor responde contractualmente frente al acreedor, por la rotura del espejo, producida por el manejo imprudente de la escalera de mano de su ayudante. Pero no responde contractualmente, en cambio, cuando su ayudante, aprovechando la oportunidad de hallarse solo en al domicilio de las obras, perpetra en ella un hurto de un cuadro del acreedor.

La diferencia radica, precisa Larenz, en que el deber de tratar atenta, cuidadosamente, las cosa del acreedor, con las que el ayudante entre en contacto en la ejecución del trabajo encomendado, es un deber de protección específico, nacido de la obligación del deudor, mientras que el deber de abstenerse de hurtar, por el contrario, existe para cualquiera que tenga acceso a cosa ajenas, y en cualquier situación, por lo que no es específicamente contractual. ${ }^{313}$

En Italia, subraya Benatti, algunos autores han asumido su formulación originaria (Schutzpflichten), otros, luego de haberla sometido a un acucioso análisis han considerado que no se puede acoger el principio según el cual habría responsabilidad contractual toda vez que un daño se cause con ocasión del contrato.

En tal sentido, debería responder ex contractu el artesano que, trabajando en casa del comitente, roba una cosa de este último, o bien el arrendador que hiere al arrendatario en el curso de una discusión sobre el monto de la renta o alquiler. Sobre la base de tales hechos se ha concluido que, para que se pueda hablar de responsabilidad contractual, es necesario que el daño sufrido por la persona o por las cosas de una de las partes sea causado por a

${ }^{313}$ LARENZ, I, Ob. Cit., p. 302 
actividad de la otra, esencialmente vinculada a la ejecución del contrato. ${ }^{314}$

\section{2.- CRITERIO DE DETERMINACIÓN}

Para Jordano Fraga, ${ }^{315}$ dicho criterio no es otro que el mismo general que vale para cualquier manifestación de responsabilidad contractual, esto es, el propio contenido de la relación jurídica obligatoria de la que el deudor es parte.

La obligación del deudor, es el principio básico para entender hasta donde puede llegar la responsabilidad contractual resultante de los daños que sean consecuencia de su infracción. Bajo esta perspectiva, será la obligación misma, quien nos dirá cuales son los cuidados, atenciones y cautelas cuya observancia es exigible específicamente del deudor de esa concreta prestación, y inversamente qué daños del acreedor entrañan infracción contractual, que importen una violación de un deber específico-obligacional de protección.

Siguiendo este orden de ideas, para la aplicación de las reglas de responsabilidad contractual a daños no prestacionales, será imperioso que dichos daños tengan una correspondencia funcional con el objeto de la obligación principal, es decir, que exista una

\footnotetext{
${ }^{314}$ BENATTI, Ob. Cit., p. 1348.

315 JORDANO FRAGA, La responsabilidad del...”.p. 244.
} 
conexión suficientemente estrecha entre la ejecución de la obligación y la salvaguardia de los bienes. ${ }^{316}$

Debemos recordar, que la hipótesis central en el que se desarrollan los deberes de protección, radica en la exposición de la propia esfera jurídica mediante el contacto negocial a la injerencia de la otra parte, por tanto, parece ser lógico que para que se articule la responsabilidad contractual, se requiera una debida correspondencia entre la naturaleza de la prestación debida y los eventuales daños no prestacionales.

Esto implica, que para que un daño producido por la violación de un deber de protección, de lugar a responsabilidad de carácter contractual, tiene que haber sido causado por una actividad vinculada a la ejecución de la relación obligatoria. Es decir, este daño debe provenir de un vínculo suficientemente estrecho entre la prestación objeto del contrato y los riesgos de daños a los que, en la ejecución de la misma, el acreedor se encuentra expuesto.

La obligación de seguridad aparece justificada cuando la ejecución de la obligación principal expone al acreedor a ciertos riesgos que parece oportuno poner a cargo del deudor. ${ }^{317-318}$ En

\footnotetext{
${ }^{316}$ Scognamiglio, se plantea si puede conseguirse una amplia tutela de las situaciones dañosas que eventualmente se verifican en conexión al desarrollo de la relación obligatoria, y así satisfacer, a través de instrumentos técnicos más evolucionados y adecuados, la antigua aspiración de realizar, en virtud del propio vinculo obligatorio, la seguridad del acreedor y sus cosas. Scognamiglio, Renato, "Responsabilità contrattuale ed extracontrattuale", Novissimo Digesto Italiano, XV, Torino, 1980, p. 676.

${ }_{317}^{317}$ CABANILLAS SÁNCHEZ, Los deberes de protección...” p. 268.

${ }^{318}$ Algunos autores excluyen del ámbito de aplicación de los deberes de protección a contratos cuyo objeto de la prestación es la seguridad del contratante, por considerar redundante la doble protección, así lo expone Le Tourneau: "Si la persona es el objeto principal del contrato, los daños corporales que podrían llegar a sufrir entran sin más en la
} 
consecuencia, será necesario que el daño sufrido por la persona o las cosas de una de las partes sea causado por una actividad de la otra, conexa a la ejecución del contrato, ósea, que será preciso que el daño derive causalmente de la ejecución de la prestación principal. ${ }^{319}$

La identificación de esta causalidad entre la ejecución de la relación obligatoria y el daño de un interés diverso del de prestación, ha de proceder según una valoración típica del contrato, teniendo en cuenta la específica posibilidad de injerencia dañosa que ofrece la relación obligatoria de que se trate. Debe tratarse de un tipo contractual, que haga razonable pensar que circunstancias inherentes a la convención tornen necesario afianzar la protección de la indemnidad de uno de los contratantes. ${ }^{320}$

Un criterio útil en este sentido, es atender a los riesgos específicos de la relación obligatoria, ${ }^{321}$ valorados según estándares de normalidad y razonabilidad, es decir, según lo que cualquier persona de buena fe, que se hallare en la misma situación de las partes contratantes, consideraría acertado en su caso, la inclusión de los intereses de protección, como presupuestos necesarios del desarrollo de la prestación. En especial, para determinar aquello que sea razonable, habrá de tenerse en cuenta la naturaleza y objeto del contrato, las circunstancias del caso y los usos y prácticas del comercio o del ramo de actividad a que el mismo se refiera. ${ }^{322}$

órbita de la responsabilidad contractual, sin tener la necesidad de recurrir a una noción complementaria. Véase, Le TOURNEAU, Droit de la responsabilité .... Ob. Cit., p. 664.

${ }^{319}$ Mengoni, Obligazioni di ...Ob. Cit., pp. 369.

${ }^{320}$ LAMBERT FAIVRE, Ob. Cit., p. 84.

${ }^{321}$ Una nota común, podemos identificarla en aquellos contratos cuya ejecución expone al acreedor a riesgos particulares a los cuales terceros no están normalmente expuestos. Véase, Welsch, Sylvie, Responsabilité du médecin, Collection Pratique Professionnelle, Juris Classeur, Editions Litec, $2^{\text {ème }}$ ed., Paris, 2003, pp. 7 y ss.

${ }^{322}$ PECL Artículo 1:302: Definición de lo razonable 
En síntesis, para evitar un indebido vaciamiento de la responsabilidad extracontractual, no basta con que el daño al acreedor se produzca bajo el imperio temporal del contrato, si no que, es preciso que suponga una infracción o violación de un deber específico del deudor tenga la debida conexión con la ejecución de la prestación principal. Es decir, para cada parte contratante, hay que fijar el contenido de su obligación, bajo los criterios de normalidad y razonabilidad (integrada por la buena fe) le exige en orden a preservar la integridad de los interés no prestacionales de su contraparte. 
CAPÍTULO SEGUNDO: "EL DEBER DE PROTECCIÓN" 


\section{Capítulo Tercero}

\section{FUNDAMENTO NORMATIVO DEL DEBER DE PROTECCIÓN}

En el presente capítulo, trataremos de encontrar una explicación lógica-jurídica para la aplicación de los deberes de protección en la orbita del contrato. Es decir, trataremos de determinar cual o cuales son la razones por la que el Derecho supone como justificado la incorporación de los deberes de protección en la relación obligacional, con todas sus ulteriores consecuencias, que en el campo de la responsabilidad civil conllevan.

Para ello, necesitaremos hacernos de un fundamento normativo concreto y real. Nos referimos a la formulación de principios generales que justifiquen en un ordenamiento jurídico determinado, tal decisión dogmática. Este fundamento normativo, debe estar apoyado en una argumentación lógica que establezca por qué es correcta la aplicación de una consecuencia jurídica, de manera que sostenga y afirme su validez.

Para nosotros esta razón concreta, se encuentra contenida sustancialmente en el principio general de la buena fe. Es esta fuerza inmaterial eminentemente ética, la que nos conduce a creer como correcto la inclusión de la protección como un deber en el programa prestacional. 
Para su acertado análisis, debemos recorrer someramente la noción y objeto de los principios generales del derecho, estudiar el origen y evolución del instituto de la buena fe, sus funciones y manifestaciones en el ordenamiento. Revisar, concretamente como la buena fe contractual integra a los deberes de protección en el iter contractual y justifica dichas consecuencias. También estudiaremos, otras posibles fuentes que explican indirectamente la aplicación de los deberes de protección.

Con todo, intentaremos demostrar que el fenómeno de los deberes de protección tiene una adecuada justificación lógicanormativa y moral en el ordenamiento jurídico, por cuanto, su reconocimiento importa una protección a la propia persona y en su dignidad e igualdad.

\section{I.- PRINCIPIOS GENERALES DE DERECHO}

Todo conocimiento científico presupone la idea de principios, es decir, de ciertos enunciados lógicos admitidos como condición o base de validez del razonamiento de que se trate. En lo tocante a nuestra ciencia, los principios generales, son verdades jurídicas indubitables y generales en las que se funda el derecho, las cuales, son utilizadas para resolver los casos no considerados por el legislador.

Como es claro, al ordenamiento jurídico positivo no le es posible regular todas y cada una de las posibles situaciones que puedan acontecer en la vida cotidiana, y es por ello, que se ve en la 
imperante necesidad de recurrir a fuentes distintas a las de la ley, mucho más superiores y generales. Al respecto comenta Del Vecchio: "No hay interferencia alguna entre los hombres, no hay controversia posible, por muy complicada e imprevista que sea, que no admita y exija una solución jurídica cierta" ${ }^{323}$

Larenz, entiende que los principios generales son los pensamientos directores de una regulación jurídica existente o posible. En si no son reglas susceptibles de aplicación, pero pueden transformarse en reglas, cuando remiten a un contenido intelectivo que conduce a una regulación. ${ }^{324}$

Por su parte Puig Brutau, señala que lo que caracteriza a los principios de generales, es que no contienen una referencia concreta al supuesto de hecho de su aplicación. En este sentido, un principio no es una norma jurídica en el sentido técnico, por que no contiene indicación vinculante con carácter inmediato para un determinado campo de problemas, se convertirá en una norma -técnicamente hablando- cuando el legislador o el juez lo apliquen. ${ }^{325}$

Los principios generales del derecho se imponen por su propia fuerza persuasiva, sin estar referidos a hechos concretos. De los Mozos $^{326}$ nos advierte, que se puede hablar de principios generales del derecho en diversos sentidos.

\footnotetext{
${ }^{323}$ DEL VECCHIO, Giorgio, Los principios generales del Derecho, trad. Juan Ossorio Morales, $3^{\text {a }}$ ed. Bosch, Barcelona, 1971, p. 40.

${ }^{324}$ LARENZ, Karl, Derecho justo: fundamentos de ética jurídica, trad. Luis Diez-Picazo, Civitas Madrid, 1985, p. 32.

${ }_{325}$ PUIG BrUTAU, José, Introducción al derecho civil, Bosch, Barcelona, 1981, p 119.

${ }^{326}$ De Los Mozos, José Luís, Metodología y ciencia del derecho privado moderno, Editorial de Derecho reunidas, Madrid, 1977, p. 104.
} 
Bajo esta perspectiva, en la historia del pensamiento jurídico han existidos variadas teorías -incluso antagonistas entre ellas-, ${ }^{327}$ que han tratado de explicar y justificar la noción de principios generales de derecho. No obstante, y más allá de las controversias, en general todas las corrientes de pensamiento reconocen la existencia de los principios generales, sea cual sea el nombre que se les dé.

Lo cierto, es que mal podría concebirse un ordenamiento sin principios que lo integren, pues, como hemos sostenido, toda legislación, por erudita y completa que sea, jamás tendrá en sí la capacidad de regular todas las eventualidades que plantea la realidad social en que esta inmersa.

\section{1.- ORIGEN}

Como acertadamente acusa Guzmán Brito, ${ }^{328}$ resulta muy común en las investigaciones sobre los principios generales de

\footnotetext{
${ }^{327}$ Como antagonistas acérrimos las tesis iusnaturalista y positivistas. A saber, la doctrina iusnaturalista, entre cuyos expositores destacan Tomás de Aquino, Del Vecchio en Italia, Stamler en Alemania, Renard en Francia, De Castro y Bravo, Castán Tobeñas, Pérez González y Alguer en España, conciben a los principios generales como ciertas directrices anteriores y superiores al ordenamiento positivo. De manera, son estos principios los que dan vida e informan a la totalidad del ordenamiento jurídico. Por su parte la doctrina positivista, como contrapartida, asimila el Derecho a la ley escrita. De este modo, todo aquello con carácter extralegal carece de significación jurídica. Con todo, tempranamente los codificadores tuvieron conciencia de que la ley era insuficiente como única fuente de Derecho, y recurrieron a los principios generales del Derecho. Pero estos ya no fueron considerados atemporales, universales o superiores al ordenamiento jurídico, sino que se les consideró como fuente supletoria de la ley, tan solo en la medida que tuviesen una consagración positiva. En esta posición destacan los nombres de Coviello, De Ruggiero y Groppali, entre muchos otros.

${ }^{328}$ GUZMÁN BRITO, Alejandro, "La idea de «principio» mentada en la expresión «principios generales de Derecho»" en Principios Generales de Derecho. Antecedentes históricos y horizonte actual, (Dir.) Fernando Reinoso Barbero, Thomson Reuters, Madrid, 2014, pp. 12.
} 
derecho, omitir de dicho examen, una noción previa y sustantiva como es la propia noción de "principio", como si se diera por sentada y conocida.

La palabra "principio", ya en la Grecia antigua, denotó un concepto filosófico. En este sentido, Aristóteles ${ }^{329}$ fue el primero en tratar orgánicamente la noción de "principio" ("arché-principium"), en el libro $\mathrm{V}$ de su Metaphysica, Aristóteles ofreció en su obra siete acepciones para el termino "arché". Concluye Guzmán Brito, que la acepción de principio válida para noción de principios generales de derecho, es la sexta, vale decir, algo que funcione como punto desde donde una cosa empieza a ser cognoscible, como las premisas que son el principio de las demostraciones. ${ }^{330}$

En Roma, la noción de principios generales de derecho, no tuvo formalmente la categoría que ocupamos en la actualidad. Sus antecedentes se remontan al mantenimiento de la concepción de la ley no escrita vinculada a las ideas de la ratio iuris, natura regnum, pieta, humanitas, o al Derecho constituido more et aequitate. ${ }^{331}$ Un ejemplo de aquello, es la figura empleada en la ley XIII, del párrafo $7^{\circ}$ del titulo I, libro XXVII del Digesto, que aceptaba a falta de ley expresa podrá resolverse de acuerdo con la naturali iustitia. ${ }^{332}$

\footnotetext{
${ }^{329}$ La palabra griega "arché" significa, en realidad "comienzo", "origen, "principio", pero también "fundamento" y "elemento". Por su parte, la palabra "princeps", significa el que toma el primer lugar, la primera parte, el primer rango. Véase, GUZMÁN BRITO, Ob. Cit., notas 2 y 3 , p. 1.

${ }_{330}^{3}$ GUZMÁN BRITO, Ob. Cit., p. 9.

${ }^{331}$ De Castro y Bravo, Federico, Derecho Civil de España, Parte general, t. I., Libro preliminar. Introducción al Derecho Civil, Instituto de Estudios Políticos, Madrid, 1955, p. 449.

${ }^{332}$ GARDELLA, Lorenzo, "Principios generales del derecho" en Enciclopedia Jurídica Omeba, t. XXII, Buenos Aires, 1967, p. 129.
} 
En la Edad Media, se defiende la idea de un Derecho natural teorizada por la Escolástica, la ley y la norma no formulada derivan de un origen que es el Derecho natural. Así para Tomás de Aquino la ley humana desciende de la ley natural de la que se derivan como "conclusión del principio" (ius gentium) o "por modo de determinación particular" (ius civile). ${ }^{333}$

Este criterio medieval lo podemos observar en las Partidas, titulo 34, Partida 7, que llevaba la rúbrica "De las reglas del Derecho", al aludir, tras la última regla recogida y en su párrafo final, a "las otras palabras que los antiguos pusieron como reglas de derecho [...] puestas e departidas por las leyes deste nuestro libro [...]". ${ }^{334}$

En la etapa de las codificaciones, al redactarse el Código Civil francés, se planteo desde un punto de vista teórico y práctico el problema de la insuficiencia de la ley y la necesidad de dar al juez la posibilidad de recurrir a una fuente que la supliera.

De esta manera al formularse el titulo preliminar del Code, se vio la conveniencia de que uno de los artículos (el 11) determinara la ley que debía aplicarse como supletoria en caso de insuficiencia. En dicha discusión se propusieron varias fórmulas, tales como máximas de Derecho natural, de la justicia natural, de la razón, ley natural, equidad natural, la ciencia, el derecho romano, el derecho común, las antiguas costumbres, la jurisprudencia, los usos y máximas y

\footnotetext{
${ }^{333}$ AzÚA ReYES, Sergio, Los principios generales de derecho, Porrúa, México, 1986, p. 2.

${ }^{334}$ GoRdillo CAÑAS, Antonio, "Comentarios al art. 1.4 del Código Civil" en Comentarios al Código Civil y Compilaciones Forales, (Dir.) Albarejo y Díaz Albart, Revista de Derecho Privado, Madrid, 1992, p. 267.
} 
decisiones de los tribunales, asimismo se propuso como fuente supletoria de la ley a "los principios generales". 335

Es aquí, en donde por primera vez encontramos una referencia a los principios generales, con una tendencia a convertirse en fuente consagrada por el derecho positivo para dar solución a casos no previstos expresamente por la ley.

No obstante, tales ideas terminan por omitirse y erradicarse del texto definitivo del Code, a causa por una parte, de la gran hostilidad que pesaba en los revolucionarios hacia la judicatura, considerada como una herramienta del antiguo régimen, y por otra, por la marcada imposición ideológica de Rousseau, contenida por la supremacía de la ley como emanación de la voluntad general y la equiparación metafísica entre la ley y la razón. ${ }^{336}$ Napoleón, pretendía haber creado una legislación tan completa que no necesitaba recurrir a los principios del derecho. ${ }^{337}$

Habrá que esperar hasta la promulgación del Código Civil austriaco de 1811, para que las discusiones ventiladas anteriormente se consagren en el texto como fuente supletoria, si bien, no bajo la locución "principios generales", sino bajo la formula: "natürlichen

\footnotetext{
${ }^{335}$ AzÚA ReYEs, Ob. Cit., pp. 4-5.; De CAStRo y BRAVo, Federico, "Los principios generales del Derecho", en Derecho Civil de España, cap. IV, Civitas, Madrid, 1984, p. 407.

${ }^{336}$ TARDío PATO, José Antonio, Los principios generales del Derecho, Bosch, Barcelona, 2011, pp. 26-27.

${ }^{337} \mathrm{El}$ artículo $4^{\circ}$ del Code original, prescribía: "El juez que rehusare juzgar pretextando silencio, oscuridad o insuficiencia de la ley, podrá ser perseguido como culpable de denegación de justicia". A su vez, el artículo 185 del Código penal señalaba: "Todo juez o tribunal, todo administrador o autoridad administrativa que bajo cualquier pretexto aun el de silencio u obscuridad de la ley se niegue hacer la justicia que debe, a las partes, será castigado con una multa de 200 a 500 francos y prohibición de ejercer sus funciones desde cinco a veinte años". Véase, AZÚA REYES, Ob. Cit., p. 6.
} 
Rechtsgrundsätzen" ("principios jurídicos naturales). ${ }^{338} \mathrm{De}$ esta manera, se imprime un enorme avance respecto a su antecesor, el juez austriaco, lejos de encontrarse en el dilema que presentaba el Código de Napoleón, podía recurrir a los principios jurídicos naturales para resolver la controversia. Para muchos autores esta fórmula significó la prueba indubitada de la recepción del Derecho natural en relación a la génesis de los principios generales de derecho. ${ }^{339}$

Luego, le seguirá en este sentido el Código Civil de Luisiana de 1825. ${ }^{340}$ Este Estado americano llamado Luisiana situado en la cuenca del Mississippi, descubierto en 1542, pertenecía alternativamente a España y Francia, terminó por integrase a Estados Unidos a fines del 1803. Frente a la necesidad de poner fin a la confusión de leyes por la que se gobernaba, -o sea leyes españolas, francesas y norteamericanas-, expidió su propio Código Civil, inspirado en las ideas del jurista Portalis el artículo 21 establecía: "En las materias civiles, a falta de ley expresa el juez está obligado a proceder y decidir conforme a la equidad, para lo que es preciso recurrir a la ley natural y a la razón, o a los usos reconocidos, en silencio de la ley positiva. ${ }^{341}$

\footnotetext{
${ }^{338}$ Rezaba el artículo 7 del Código Civil de Austria: "Si no se puede decidir una cuestión jurídica ni conforme a las palabras ni según el sentido de una ley, se tendrá en cuenta lo que se decida por la ley, en los casos análogas. Si resultase aún dudoso el caso se decidirá de acuerdo a las circunstancias cuidadosamente recogidas y maduramente pesadas, según los principios jurídicos naturales". [...] Läßt sich ein Rechtsfall weder aus den Worten, noch aus dem natürlinchen Sinne eines Hesetzes entscheiden, so muß auf ähnliche, in den Gesetzen bestimmt entschiedene Fälle, und die Gruünde anderer damit verwandten Gesetze Rücksicht genommen werden. Bleibt der Rechtfall noch zweifelhaft; so muß solcher mit Hinsicht auf die sorgfältig gesammelten und reiflich erwogwnwn Unstände nach den natUrlinchen Rechtsgrundsätzen entschieden werden [...].

${ }^{339}$ Véase al respecto, RODRIGUEZ BOENTE, Sonia, Los principios generales de derecho, Univ. Santiago de Compostela, 2008, p. 19.p

${ }^{340}$ AZÚA REYES, Ob. Cit., p. 8.

${ }^{341}[\ldots]$ "In civil matters, where there is no express law, the judge is bound to proceed and decide according to equitably, an appeal is no be made to natural law ans reason, or received usages, where positive law is silent' [...].
} 
Sin perjuicio de lo comentado, no será hasta la promulgación del Código Civil italiano en 1865, que se podrá hablar propiamente de "principios generales de derecho". Dicho texto legal consagra en su artículo $3^{\circ}$ la fórmula de "principios generales de Derecho", ${ }^{342}$ cuyos antecedentes, los encontramos, a su vez en el Código Albertino de 1837 (Código Civil de Piamonte). ${ }^{343}$

Tanto para Del Vecchio como para De Castro, el Legislador italiano no parece que estuviese pensando en algo distinto que los natürlichen Rechtsgrundsätzen del Código austriaco, dirección, que a la postre cambiaría con la aprobación de Código Civil italiano de 1942, que alude a "los principios del ordenamiento jurídico de Estado", en una posición mucho más positivista y racionalista. ${ }^{344}$

En España, en 1851 García Goyena toma en el artículo 12 de su proyecto, la formula "principios generales del derecho", del Código Albertino. Posteriormente, el Código Civil español de 1889, en su redacción original indicaba: "El tribunal que rehusé fallar a pretexto de

\footnotetext{
${ }^{342}$ El artículo $3^{\circ}$ del Código Civil de Italia de 1865 consignaba que: "Cuando una controversia no se pueda decidir con una disposición normativa precisa, se tendrá en cuenta disposiciones que regulen casos similares o materias analógicas: si el caso presentase todavía duda, se decidirá según los principios generales de Derecho". ("Qualora un controversia non si possa decidere con una precisa disposizione di legge, si avrà riguardo alle disposizioni che regalono casi simili o materia analoghe: ove il caso rimanga tuttavia dubbio, si deciderà secondo i principii generali di diritto").

${ }^{343}$ En la elaboración del Código Albertino de los Estados Sardos, Piamonte de 1837, se habló de los "principii generali del diritto naturale". En la discusión parlamentaria Piamontesa se señalaron fórmulas como Derecho Común o Principios de Equidad. No obstante en la comisión legislativa, se prefirió en contra de la expresión derecho común, por ser esta última demasiado general e inversa con la soberanía jurídica del Código que se intentaba por monarca Carlos Alberto, la expresión principios generales. Así en su artículo 15 el Código Albertino estableció: "Si una cuestión no pude ser resuelta ni por el texto ni por el espíritu de la ley, se tendrá en consideración los casos semejantes que las leyes hayan previsto especialmente y los fundamentos de otras leyes análogas; si a pesar de ello la cuestión es todavía dudosa, deberá decidirse según los principios generales del derecho, tomando en consideración todas las circunstancias del caso". Véase, AZÚA REYES, Ob. Cit., p. 9.

${ }^{344}$ Del VeCChIO, Ob. Cit., p. 46; De Castro y Bravo, "Los principios generales ..." Ob. Cit., p. 407 .
} 
silencio, oscuridad o insuficiencia de las leyes, incurrirá en responsabilidad. Cuando no haya ley exactamente aplicable al punto controvertido, se aplicará la costumbre del lugar, y en su defecto, los principios generales del Derecho". ${ }^{345} \mathrm{El}$ actual Código civil español, reconoce en su articulo $1^{\circ}$ como fuente del ordenamiento a los principios generales de derecho.

Entre los Códigos Civiles latinoamericanos, de los siglos XIX y $X X$, son múltiples los que citan la fórmula precedente. Chile en 1857 , Ecuador en 1861, Uruguay en 1868, Argentina en 1871, México, en 1870, Colombia en 1897, Paraguay en 1889, Honduras 1899, Brasil en 1816, Perú en 1936 y Venezuela en $1942 .{ }^{346}$

La importancia de los principios generales de derecho, es en la actualidad indubitada, reconocidos como una institución fundamental dentro de la ciencia del derecho, incorporados por vía directa o indirecta en la mayoría de los ordenamiento jurídicos modernos. ${ }^{347}$

Un ejemplo de anterior, es la recepción de este principio por el Derecho Internacional, en el artículo 38 del Estatuto de la Corte Permanente de Justicia de la Haya el 13 de diciembre de 1920, y en el artículo 38.1 letra c del Estatuto del Tribunal internacional de Justicia, que forma parte de la Carta de las Naciones Unidas del 26 de junio de $1945 .^{348}$

\footnotetext{
${ }^{345}$ TARDío PATO, Ob. Cit., p. 28.

${ }^{346}$ Véase, AZÚA REYES, Ob. Cit., p. 13.

${ }^{347}$ Incluso en los países donde el Código civil no los reconoce expresamente como fuente de derecho. Así por ejemplo en Francia y Alemania, se llegará a ellos a través de la prohibición "non liquet" a los jueces. TARDío PATO, Ob. Cit., pp. 32-35.

${ }^{348}$ TARDí PATO, Ob. Cit., p. 28.
} 


\section{2.- NATURALEZA Y FUNCIONES}

Ya es tradicional, y puede que hasta interminable si se quiere, la discusión sobre cual es la naturaleza jurídica de los principios generales de derecho. En esta disputa se enfrentan dos bandos intransigentes, iusnaturalismo y positivismo. ${ }^{349}$ Para uno los principios generales de derecho emanan exclusivamente del la ley escrita y vigente. Para el otro, estos principios son anteriores a la ley inmutables y generales.

Para nosotros, los principios generales del derecho, pertenecen al mundo del "ser" como reflejo de los valores que son, y colaboran en la determinación del mundo del "deber ser". Es una relación simbiótica, las normas se fundan en los principios generales, y estos a su vez están contenidos en aquellas. Un principio general no es una norma jurídica en sentido técnico, por cuanto, no tiene un indicación vinculante. No obstante, se convertirá en norma cuando es determinado por el legislador o por el juez.

Los principios generales de derecho, son derecho positivo pues, el derecho se remite a ellos para cumplir su plenitud, rigen más allá de su reconocimiento expreso de este, ya que, de su esencia se deduce una norma de conducta debida. Lo principios generales de derecho no son en consecuencia simples criterios morales, si no por el contrario poseen fuerza imperativa directa, esta característica denominada potencialidad jurígena, es decir, los principios generales

\footnotetext{
${ }^{349}$ Supra Nota n ${ }^{\circ} 327$
} 
pueden crear normas concretas de conducta, esto es, como una real fuente de derechos y obligaciones, plenamente exigibles por los miembros de una relación intersubjetiva.

Como ilustra el maestro Del Vecchio, los principios jurídicos, a pesar de tener un carácter ideal y absoluto, por consecuencia del cual superan virtualmente al sistema concreto de que forman parte, no pueden prevalecer en contra de las normas particulares que lo componen, ni destruirlas en ningún caso, pero tienen valor, sin embargo, sobre y dentro de tales normas, puesto que, representan la razón suprema y el espíritu que las informa. Ya que, no solo son un elemento fundamental de un sistema determinado, sino una fuerza viva, que domina todos los sistemas y actúa sobre las estructura de éstos, haciendo que se modifiquen y evolucionen según los principios eternos de la justicia, inherentes a la naturaleza humana. ${ }^{350}$

De lo expuesto, es posible concluir que los principios generales de derecho cumplen las siguientes funciones dentro del ordenamiento jurídico:

\section{a.- Función informadora}

En primer termino, los principios generales de derecho son fundamento de todo ordenamiento jurídico, por lo que toda norma positiva debe elaborarse conforme a ellos. De los Mozos, señala que el legislador está llamado a respetar los principios, no a regularlos, ni

\footnotetext{
${ }^{350}$ Del VeCCHIO, Ob. Cit., pp.137-139.
} 
siquiera a enunciarlos, sino que debe remitirse a ellos cuando lo crea conveniente. ${ }^{351}$

En razón de esta función, se sostiene que son los principios generales de derecho los que dan al ordenamiento jurídico su carácter de unidad y sistematicidad, esto es, que cada una de las normas pertenecientes a él tiene como fundamento último una misma norma, regla o principio. ${ }^{352}$

Lo anterior importa dos consecuencias, la primera consiste en inspirar una pluralidad de normas, que constituyen manifestaciones del mismo principio, al estar imbuidas por éste. La segunda, supone la necesidad de que determinadas normas tengan que ser conformes con el correspondiente principio general, de modo que, si no lo son, serán antijurídicas, al configurase el principio genera de derecho como parámetro de la juridicidad de dichas normas o reglas. Esta última consecuencia De Castro la calificó como fundamento de ordenamiento jurídico. $^{353}$

\section{b.- Función integradora}

\footnotetext{
${ }^{351}$ DE LOS MOZOS, José Luis, El principio de la buena fe. Sus aplicaciones prácticas en el Derecho Civil español, Bosch, Barcelona, 1965.

${ }^{352}$ Con todo, si bien existe cierto consenso en cuanto a que existe un "algo" que le da la unidad al ordenamiento jurídico, han existido distintas posiciones acerca de qué es ese "algo". Para Kelsen aquello que le da la unidad al ordenamiento jurídico no es una norma positiva, sino que una norma pre-supuesta, a la cual llama norma hipotética fundamental, la que nos conduce a obedecer al primer legislador. Por el contrario para Hart, la unidad descansa ya no en una norma presupuesta, sino que en un principio o acuerdo mayoritariamente aceptado por la sociedad. Véase al respecto KELSEN, Hans, Teoría pura del Derecho Eudeba, Buenos Aires, 1973; HART Herbert, El concepto del Derecho, Albeledo Perot, Buenos Aires, 1977.

${ }^{353}$ DE CASTRO Y BRAVO, Ob. Cit., p. 473.
} 
Como hemos señalado, al legislador le resulta imposible anticiparse a todos y cada uno de los distintos acontecimientos que pueden acaecer en la vida jurídica. Por otra parte, la vida moderna ha hecho surgir una innumerable serie de nuevas situaciones de carácter complejo, las cuales no eran previsibles para el legislador de los siglos pasados, de lo que se sigue que no encuentran solución en el ordenamiento positivo.

De ahí que sea necesario recurrir a conceptos de carácter extrapositivo que permitan dar solución a todas las situaciones jurídicas no reguladas. En este orden de ideas, nos encontramos a los principios generales de derecho como criterios para resolver cuando a falta de un precepto satisfactorio, o dicho otro modo, lo que se afirma aquí no es otra cosa que, el carácter de fuente de derecho de los principios generales de derecho

El problema de las lagunas es un dilema tanto lógico como axiológico, subraya Legaz y Lacambra: "El juez, cuando se encuentra ante una supuesta laguna, no se halla en presencia de dos problemas distintos, uno lógico-jurídico y otro estimativo. Sino ante un único caso jurídico que implica en unidad indestructible los dos problemas, y ante el cual ha de adoptar una decisión que forma parte del ordenamiento jurídico, integrándolo como un todo pleno, llevándose así a sus ultimas consecuencias el postulado de la plenitud del orden jurídico". 354

${ }^{354}$ LEgAZ Y LACAMBRA, Luis, Filosofía de Derecho, Bosch, $4^{a}$ ed., Barcelona, 1975, p. 547. 
En la doctrina española, los principios generales de derecho son una fuente supletoria, esto es, tan solo crearán derechos y obligaciones, y regularán solo las situaciones no contempladas expresamente por el ordenamiento positivo. ${ }^{355}$

Diez-Picazo, señala que los principios tienen una doble función: por una parte inspiran a todo el ordenamiento jurídico y por otra plantean su aplicación directa en defecto e la ley y la costumbre. ${ }^{356}$ Con todo, desde la incorporación del articulo 7.1 en el Código Civil español, que establece que los derechos deberán ejercerse de buena fe, algunos autores han señalado que, tratándose de del principio general de la buena fe, ya no existe tal subsidiaridad. ${ }^{357}$

En Chile, si bien no existe una norma que mencione de manera expresa la función integradora de los principios generales de derecho, la doctrina y jurisprudencia mayoritarias ha señalado que tales principios se consagran en la fórmula "espíritu general de la legislación" empleada por el artículo 24 del Código Civil chileno. En tal sentido Rodríguez Grez, sostiene que los principios generales son el más importante y fecundo de los elementos de integración de la laguna legales, por cuanto constituyen una especie de síntesis de la legislación en general. ${ }^{358}$

\footnotetext{
${ }^{355}$ Esta posición encuentra su asidero en el Titulo Preliminar del Código Civil español, que en su artículo 1.4. "Los principios generales de derecho se aplicarán en defecto de la leo o costumbre, sin perjuicio de su carácter informador del ordenamiento jurídico".

${ }^{356}$ DiEZ-PICAZO, Luis, Experiencia jurídicas y teoría del Derecho, Tecnos, Madrid, 1973, p. 200.

${ }^{357}$ En este sentido, Ferreira Rubio indica: "Pero hay un avance todavía más importante, en el logro del cual convergen, a nuestro juicio, la norma del artículo 1.4 y la del 7.1, es el hecho de que cualquier sospecha de subsidiaridad que pudiere recaer sobre él, ha desaparecido". FERREIRA RUBIO, Delia Matilde, La buena fe. El principio general en el Derecho Civil. Montecorbo, $1^{\text {a }}$ ed., Madrid, 1984, p. 301.

${ }^{358}$ Rodríguez Grez, Pablo, Teoría de la interpretación jurídica, Editorial Jurídica de Chile, $1^{\mathrm{a}}$ ed., Santiago, 1990, pp. 27-28.
} 
c.- Función interpretativa

Esta función es la que detenta mayor acuerdo, y reconocimiento por prácticamente la unanimidad de la doctrina. Diez-Picazo, señala "también la determinación del verdadero alcance, sentido y significación que dentro del ordenamiento jurídico posee una determinada disposición legal solamente puede hacerse, en ocasiones, acudiendo a criterios extralegales. Cuando hablamos pues, de "principios generales de Derecho" estamos haciendo referencia estos criterios no legislados ni consuetudinarios mediantes los cuales debemos integrar las lagunas legales y de los cuales debemos servirnos para llevar a cabo la labor de interpretación de la leyes". 359

De esta manera, el juez necesariamente debe llevar a cabo su labor hermenéutica acudiendo a los principios generales para respetar la unidad y coherencia del ordenamiento jurídico.

La diferencia entre la función integradora y la función interpretativa de los principios generales de derecho, reside en que, en la función integradora, no existe norma o regla que aplicar, y se aplica directamente los principios generales de derecho, cuyo supuesto de hecho genérico, es subsumible al referido supuesto particular de la vida real. En cambio en los casos de aplicación de un principio general de derecho como función interpretativa, sí que existe norma o regla aplicable, pero, al permitir el desentrañamiento de su

359 DiEZ-PICAZO, Experiencia jurídicas...” Ob. Cit., p. 202. 
significado dos o más sentidos diversos, se opta por el más conforme con el principio general de derecho de referencia. ${ }^{360}$

\section{3.- EN SÍNTESIS}

Los principios generales, conforman la esencia del derecho, están en la naturaleza humana, no son una norma sino la justificación de ésta. Los principios organizan jurídicamente a la comunidad y dan al sistema jurídico racionalidad, moralidad y humanismo.

Al respecto, subraya Portalis, en el "Discurso preliminar sobre el proyecto del Código Civil Francés," 361 las leyes no son meros actos de poder, son actos de sabiduría, de justicia y de razón. Las leyes se hacen para los hombres y no los hombres para las leyes, estas deben adaptarse al carácter, a los usos, y a la situación del pueblo para el cual se dictaron. Si la ley no los regula hay que remontarse a los principios del derecho natural, pues si la previsión del legislador es limitada, la naturaleza es infinita.

La acuñación de la mayoría de los principios generales, en especial los que conservan su manera originaria de la lengua latina, exigen un largo desarrollo de evolución histórica independiente para cada uno de ellos, iniciado casi por el causismo jurisprudencial, con ensayos de soluciones jurídicas que generaciones de juristas depuran en un proceso de progreso sucesivo hasta conseguir un significado

\footnotetext{
${ }^{360}$ TARDío PATO, Ob. Cit., pp. 140-141.

${ }^{361}$ PORTALIS, Jean-Étienne-Marie, Discurso preliminar sobre el proyecto de Código civil, trad. Adela Mora, Universidad Carlos III, Madrid, 2014, pp.11-15
} 
abstracto evaluable científicamente en términos de utilidad. Esa utilidad actual de cada principio general de derecho está unida indisolublemente tanto a su vigencia como a su propia expresión que, incluso por razones de estricta índole práctica, debe ser preservada. ${ }^{362}$

\section{II.- EL PRINCIPIO GENERAL DE LA BUENA FE}

Como hemos expuesto precedentemente, un principio general de derecho, en algunos casos estará dando fundamento y proyectándose a través de una norma y, en otros casos tendrá una cara formal y visible, cuando la norma se remite o refiere a él en forma concreta, tal como sucede cuando se alude en la disposición al principio general de la buena fe. ${ }^{363}$

La buena fe se integra en un ideal de comportamiento en la vida social que ésta incorporado al orden jurídico desde la época del

\footnotetext{
${ }^{362}$ ReINOSO-BARBERO, Fernando, "Los principios generales de derecho en la modernización del lenguaje jurídico", en Principios Generales de Derecho. Antecedentes históricos y horizonte actual, (Dir.) Fernando Reinoso Barbero, Thomson Reuters, Madrid, 2014, p. 73.

${ }^{363}$ Cierta discusión se ha planteado, entre los términos buena fe y principio general de la buena fe. Por cuanto solo la buena fe objetiva sería verdaderamente un principio general del derecho. Para nosotros, el principio general de la buena fe, engloba todas sus manifestaciones, sin posibilidad de separación o distinción, ya que, sus elementos axiológicos son comunes. Sin perjuicio de ello, $n$ España, el Tribunal Supremo, ha señalado que la buena fe recogida en los arts. 7 y 1258 del CC, estaría en la concepción objetiva; "La buena fe de que habla el precepto [art. $1258 \mathrm{del} \mathrm{CC]} \mathrm{no} \mathrm{es} \mathrm{la} \mathrm{subjetiva} \mathrm{(creencia,} \mathrm{situación}$ psicológica), sino la objetiva (comportamiento honrado, justo), a la que se alude en el artículo 7 del propio Código, que consagra como norma el principio general de derecho de ese nombre". Véase, STS (Sala de lo Civil), de 6 de abril de 1988 (RJ 1988/3111). Ponente Excmo. Sr. Eduardo Fernández-Cid de Temes. Otras sentencias que reconocen la buena fe objetiva en el caso del art. 1258 del CC son la STS (Sala de lo Civil), de 9 de octubre de 1993 (RJ 1993/8174). Ponente Excmo. Sr. Pedro González Poveda; STS (Sala de lo Civil), de 17 de febrero de 1996 (RJ 1996/1408). Ponente Excmo. Sr. Pedro González Poveda; y STS (Sala de lo Civil), de 30 de junio de 2000 (RJ 2000/6747). Ponente Excmo. Sr. Alfonso Villagómez Rodil.
} 
derecho romano, constituyendo un principio universal, trascendente, reconocido y aceptado.

Así, la buena fe aparece como un principio de conducta debida, que mantiene el control de la autonomía privada. De eta manera se integran por su intermedio la necesidad de tutelar los valores inviolables de la persona, entre otras múltiples funciones que la buena fe cumple como principio general de derecho.

La buena fe ha ocupado un papel estelar en la evolución del Derecho, siendo un semillero del cual han surgido innumerables doctrinas que han cambiado la faz de los distintos ordenamientos jurídicos. No es de extrañar, por ende, la existencia de un volumen de literatura prácticamente inabarcable en torno a este prodigio normativo.

Para no extraviarnos en nuestro intento de abordar este instituto, nos ajustaremos a un plan bastante simple: trazaremos un camino, que nos relate sus notas elementales, y nos enseñe sus fronteras más generales. Para que con lo recaudado, podamos primero entender, y luego construir un fundamento acertado del fenómeno de la buena fe en relación a los deberes de protección.

\section{1.- ANTECEDENTES GENERALES}

a.- En el Derecho romano 
En la tradición romana, ${ }^{364}$ podemos señalar en términos generales, que la "fides" es entendida originariamente, como "fidelidad a la palabra dada". Su significado más básico, traducido como "ser de palabra" o "tener palabra", esto es, "hacer lo que se dice" o "cumplir lo que se promete", deriva de la propia etimología de la palabra, que nos ofrecen las fuentes, resumida en la expresión fit quod dicitur. ${ }^{365}$

Esta noción contextualizada respecto del sujeto titular de la fides; -quien, por ello, es "hombre de palabra", "cumplidor de sus compromisos"- influenció prácticamente la totalidad de los distinto ámbitos de la realidad romana, abarcando campos tan disimiles como la religión, ${ }^{366}$ las relaciones políticas e internacionales y los institutos jurídicos privados.

\footnotetext{
${ }^{364}$ Entre la abundante literatura concerniente a los términos fides y bona fides en el Derecho romano podemos destacar, a modo de ejemplo: VON TUHR, A., "La buena fe en el Derecho romano y en el actual", en Revista de Derecho Privado, No 146, Madrid, 1925, pp. 336 ss.; HORVAT, M. "Osservazioni sulla «bona fides» nel diritto romano obligatorio", en Studi Arangio-Ruiz , t. I, Milano, 1952.; GRosso, Giuseppe, voz "Buona fede (premesse romanistiche)", en EdD $N^{\circ}$ 5, Torino, 1959, pp. 661 ss.; WIEACKER, Franz, El principio general de la buena fe, trad. José Luís Carro, Civitas, Madrid, 1982.; FrEZZA, Paolo, «Fides bona», en Studi sulla buona fede, en AA. VV., Guiffrè, Milano, 1975, pp. 3 y ss; FASCIONE, Lorenzo, "Cenni bibliografici sulla «bona fides»", en Studi sulla buona fede, en AA. VV. Guiffrè, Milano, 1975, pp. 51 y ss.; GARCíA GARRIDO, Manuel Jesús, voz «Bona fides», Diccionario de jurisprudencia romana, Madrid, 1986.; CASTRESANA, Amelia, Fides, "Bona fides»: un concepto para la creación del Derecho, Tecnos, Madrid, 1991.; STOLFI, Emanuele, "Bonae fidei interpretatio». Ricerche sull'interpretazione di buona fede esperienza romana e tradizione romanistica, Napoli, 2004; LANTELLA, Lelio., "Fides e Bona fides (proiezioni semantiche ed etiche)", Civiltà europea, 2008, pp. 3 ss.; SALAZAR REVUelTA, María, "Formación en el derecho romano y en la tradición romanística del principio de la buena fe y su proyección en el derecho comunitario europeo", en Revista de Derecho Romano Internacional, abril, 2015.

${ }^{365}$ Cicerón, De re pub. 4,7,21: fides enim nomen ipsum mihi videtur habere, cum fit quod dicitur; De officis. 1,7,23: Fundamentum autem est iustitiae fides, id est dictorum conventorumque constantia et veritas. Ex quo...audeamus imitari Stoicos, qui studiose exquirunt, unde verba sint ducta, credamusque, quia fiat, quod dictum est, appellatam fidem; Isidoro de Sevilla, Orig. 8,2,4: nomen fidei inde est dictum, si omnino fiat quod dictum est aut promissum, et inde fides vocata ab eo quod fit illud quod inter deum et hominem: hinc et foedus; San Agustín, Serm. 49,2: fides appellata est ab eo fit quod dicitur. Véase, SALAZAR ReVUELTA, Ob. Cit., p. 117.

${ }^{366}$ En Roma la fides solía obrar a la vez tanto en materia religiosa como jurídica. En Roma se invocaba a la diosa Fides en la celebración de los negocios jurídicos ligándola
} 
Señala Frezza, ${ }^{367}$ que el primer testimonio técnico que nos encontramos respecto a la fides en el Derecho romano se encuentra en una antiquísima norma "patronus si clienti fraudem fecerit, sacer esto," formulada en las XII Tablas (Serv. ad Aen. 6, 609), señala este autor, que en esta norma no encontramos literalmente la palabra fides, sino la voz fraus que contiene en su significado el concepto opuesto al valor de la fides.

La esencia de la fides se encuentra, pues, en el respeto a lo convenido. Esta significación se percibirá notoriamente en el ius privatum, sobre todo en los negocios que impliquen el cumplimiento de una promesa obligacional. En este contexto, se destaca el valor de la fides, dado su extraordinario alcance y sus múltiples funciones en el mundo del Derecho. En efecto, su contenido se revela claramente heterogéneo, apareciendo en ámbitos de la realidad romana muy diferentes como fides in deditione, fides in colloquio, fides publica, fides patroni, fides crediticia, bona fides. ${ }^{368}$

Posteriormente, la vasta labor jurisprudencial y doctrinal ${ }^{369}$ que encontramos en torno al término, referidas al campo del derecho

estrechamente con el iusiurandum, como affirmatio religiosa. La palma de la mano era consagrada a la diosa y por eso los contratantes apretaban las manos al finalizar el negocio, a fin de sacramentar lo convenido. Véase, KLUGER, Viviana, "Una mirada hacia atrás: desde Roma a la Codificación. El recorrido histórico de la buena fe", en Tratado de la buena fe en el Derecho, t. I., (Dir.) Marcos Córdoba, editorial La Ley, $1^{\mathrm{a}}$ ed. Buenos Aires, 2004 p. 90.

${ }_{367}^{367}$ FrEZZA, Ob. Cit., pp. 3-4.

${ }^{368}$ Un análisis textual y etimológico de estas expresiones se encuentra en FREYBURGER, Gérard, «Fides». Étude sémantique et religieuse depuis les origines jusqu'à l'époque augustéenne, Paris, 1986, pp. 31 ss.

${ }^{369}$ Así, la creación del pretor, los iudicia bonae fidei, basados en la recíproca lealtad al acuerdo o negocio convenido nuevos juicios ampararán bajo el manto flexible de la bona fides numerosas acciones civiles, tanto derivadas de contratos, como de cuasicontratos, 
público romano, concretamente a su papel en las relaciones y tratados internacionales. ${ }^{370-371}$ Decanta paulatinamente en variadas figuras jurídico-privadas, hasta llegar al concepto de bona fides, contractual y posesoria. $^{372}$

De esta manera, en los distintos textos romanos se comienza ocupar la locución "bona fides", lo que añadiría una idea de solidez o seguridad respecto de la simple fides, Castresana, subraya que la bona fides pasa a ser un concepto netamente jurídico, esto es, una creación procesal de la experiencia jurídica romana, cuyas características más relevantes son su naturaleza unitaria, jurídica y procesal. ${ }^{373}$ Aparece, así, la bona fides como base reguladora de los negocios jurídicos no solemnes, enriqueciendo -respecto a lo acordado por las partes- el contenido de los contratos.

así: la actio commodati, depositi, fiduciae, pigneraticia, empti, venditi, locati, conducti, pro socio, mandati, negotiorum gestiorum, tutelae, communi dividundo, familiae erciscundae, praescriptis verbis o rei uxoriae. Estas acciones cuya, introducción en la esfera oficial se produciría gracias al imperio del magistrado -apoyado, asimismo, en la labor de los juristas a lo largo de la época republicana, se caracterizan por contener en la intentio de su fórmula la expresión ex fide bona, que dejaba al juez un amplio margen de maniobra para apreciar, de una manera equitativa, las obligaciones resultantes. Véase, iudicia bonae fidei, como fundamento procesal del origen de la bona fides, en FERNÁNDEZ DE BUJÁN, Antonio, "EI papel de la buena fe en los pactos, arbitrajes y contratos" en Revista de Derecho UNED, Núm. 7, 2010.

${ }^{370}$ Un primer antecedentes de esto lo encontramos en un antiquísimo documento en que la fide viene retratada como fundamento de una obligación derivada del tratado internacional entre Roma y Cartago, de cuyo contenido informa Polibio (3, 22, 9). Véase, FREZZA, Ob. Cit., p. 4 ,

${ }^{371}$ Se estima que la bona fides surgió debido a la difusión de los negocios internacionales en el ordenamiento romano y de la inexistencia de una formalidad que permitiera la interferencia del Estado en las relaciones negóciales, pues ellas presentaba, en la mayoría de las veces características consensuales. KLUGER, Ob. Cit., p. 93.

${ }^{372} \mathrm{La}$ violación de la fides y la consecuente contravención del ius gentium aparecen mencionadas al unísono en fuentes como Livio, 4,19,3: ruptor foederis humani violatorque gentium iuris; 21,25,7: non contra ius modo gentium, sed violata etiam, quae data in id tempus erat, fide; 30,25,10: etsi non indutiarum modo fides a Carthaginiensibus, sed ius etiam gentium in legatis violatum esset. Sobre estas fuentes $y$, en general, sobre la equiparación fidesius Gentium, Véase, KASER, M., Ius Gentium, trad. Francisco. J. Andrés Santos, Granada, 2004, pp. 45 ss.

${ }^{373}$ CASTREsanA, Ob. Cit., p. 97. 
b.- En el Derecho común

Con todo, si bien se trata de un criterio objetivo, la bona fides no llega a adquirir en el Derecho romano la consideración de principio informador de todo el ordenamiento jurídico.

Son los canonistas, los que conciben la buena fe como valoración ética de la conducta del sujeto. La buena fe, en Derecho canónico, consiste en la falta de conciencia de estar engañando al propietario; como la conciencia tiene un carácter eminentemente subjetivo, el derecho de la Iglesia se interesó de manera particular, porque ella se encuentra, por así decirlo, en la zona limítrofe entre el campo reservado al fuero interno y al campo reservado al foro externo. ${ }^{374}$

Elemento fundamental de la misma será la recta conscientia, entendida como la convicción sincera de que el acto que se está realizando es lícito y legítimo, y cuyas aplicaciones pueden ser diversas en función de las diferentes situaciones jurídicas, como en el caso de la prescripción adquisitiva. ${ }^{375}$ La conscientia equivale a lo que denominamos "buena fe", Lo contrario es la laesa conscientia, de la que

\footnotetext{
${ }^{374}$ Salinas ARANeda, Carlos, "Un influjo frustrado del Derecho Canónico en el Código Civil de Chile: mala fides superveniens nocet". Rev. estudios. históricos.jurídicos. Núm. 26, Valparaíso, 2004, pp. 471.

${ }^{375}$ Un análisis más detallado sobre la incidencia de los principios jurídico-canónicos recogidos en las Decretales (lib. IV), junto con las 88 regulae iuris, que se encuentran situadas al final del Liber Sextus, en HerRera Bravo, Ramón y AguILAR Ros, Paloma, Derecho romano y Derecho canónico. Elementos formativos de las instituciones jurídicas europeas, Granada, 1994, pp. 35-38.
} 
derivan graves consecuencias en el campo jurídico, que se traducen en la falta de buena fe del adquirente. ${ }^{376}$

En la realidad comercial del Derecho común la fides equivale a securitas y a pactum. De esta forma, por ejemplo, un pactum nudum es considerado vinculante y obligatorio, porque mientras que para el Ius Commune se adoptaba el principio "ex nudo pacto obligationem non oritur", en la lex mercatoria la regla era totalmente la contraria, afirmándose el principio de la plena accionabilidad de todo pactum ya sea vestido o desnudo (inter mercatores tam importat pactum nudum quam inter alios stipulatio). ${ }^{377}$

La influencia de la fides canónica en el Derecho común, es una realidad también cuando se propugna la concordancia entre la voluntad interna y la manifestada en los negocios jurídicos (recta conscientia). Así pues, no solamente incide en cuestiones de prescripción, sino que se trata también de una exigencia durante todo el tiempo que dura la relación jurídica.

Es, asimismo, aplicable al cónyuge para que le sean atribuidos los efectos del matrimonio putativo. Igualmente, influye en la reelaboración de la teoría de las consecuencias prejudiciales de la prestación no cumplida. En materia procesal, afecta a cuestiones

\footnotetext{
${ }^{376}$ Un ejemplo lo constituye: Lib. Decret. X,2,26 c.5 : "mala fides superveniens nocet et qui praescribit in nulla temporis parte rei habeat conscientiam alienam"; Lib. Decret. X 2,26 c. 20: "Non in foro canonico nec civili valet praescriptio cum mala fide. Idem in concilio generali. Quoniam omne, quod non est ex fide, peccatum est, synodali iudicio diffinimus, ut nulla valeat absque bona fide praescriptio tam canonica quam civilis, quum generaliter sit omni constitutioni atque consuetudini derogandum, quae absque mortali peccato non potest observari. Unde oportet, ut qui praescribit in nulla temporis parte rei habeat conscientiam alie nae". Al respecto, SALINAS ARANEDA, Ob. Cit., pp. 471-489.

377 PIRENNE, Henri, Historia económica y social de la Edad Media, trad. de S. Echavarri, $10^{\mathrm{a}}$ reimpr., México, 1970, pp. 45-47
} 
como el daño y el interés, modificándose la idea que de ellos se tenía tradicionalmente. En relación a las obligaciones pecuniarias supone una novedad introducir la buena fe durante todo el tiempo de vida de éstos, para que la prescripción contractual liberatoria o extintiva fuese de aplicación. ${ }^{378}$

A lo largo de la tradición jurídica europea empieza a conformarse progresivamente la idea de que el principio de la buena es inherente a todo tipo de contrato y no sólo a aquellos que tienen naturaleza bonae fidei. Dicha extensión del principio de la bona fides a todo tipo de contrato obedece a una serie de factores: por un lado, a la influencia de la aequitas canónica y, por otro, a las prácticas comerciales del bajo Medievo con la recurrente elaboración doctrinal y jurisprudencial, generando los contratos consuetudinarios del ius mercatorum, cuya realización y ejecución se acomete conforme a la bona fides y al auxilio de los tribunales mercantiles que acuden a la aequitas mercatoria y deciden ex bono et aequo. ${ }^{379}$

La continuidad histórica de la bona fides se manifiesta claramente en el momento de la nacionalización del Derecho a través de la codificación. De este fenómeno nos ocuparemos en los siguientes apartados a propósito de la buena fe contractual como fundamento del deber inmediato de protección.

${ }^{378}$ SALAZAR ReVUelta, Ob. Cit.,. pp. 147-148

${ }^{379}$ SALAZAR ReVUELTA, Ob. Cit.,. p. 151 


\section{2.- CONCEPTO}

a.- Noción

Desde ya debemos advertir al lector, que el concepto de la buen fe ha sido uno de los que más dificultades presenta a todo autor que lo ha intentado abordar. Bajo esta perspectiva, la conceptualización de un principio tan empleado para materias a su vez tan diversas, sentencia tempranamente en prácticamente imposible cualquier tarea en dicha dirección.

La vastedad del concepto ha sido vista por más de un autor como un vicio, De Trazegnies manifiesta que: "La mayor parte de las definiciones de la buena fe no son sino malabarismos lingüísticos, delicadamente envueltos dentro de una bruma de candor y hasta de beatitud, que difícilmente pude ser utilizados con el rigor por el legislador y los tribunales, según Ripert. La buena fe es un concepto al que parece haberle sucedido un problema similar a la rana de Esopo: tanto quiso ser importante, tanto se infló para alcanzar las dimensiones del buey, que finalmente reventó, y lo que encontramos después no son sino hilachas difícilmente utilizables." ${ }^{380}$

Para nosotros, la amplitud y flexibilidad del concepto no es más que una característica propia y necesaria de la naturaleza de la buena

\footnotetext{
${ }^{380}$ De Trazegnies Granada, Fernando, "Desacralizando la buena fe en el Derecho" en Tratado de la buena fe en el Derecho, t. II. (Dir.) Marcos M. Córdoba, Editorial La Ley, $1^{\text {a }}$ ed., Buenos Aires, 2004, p. 25.
} 
fe como principio general de derecho, circunstancia que resulta más próxima a una virtud que a un defecto.

Por ello, resulta indefendible pretender constreñir a la buena fe a una fórmula precisa y estricta, bajo el pretexto de extender su seguridad jurídica, puesto que, solo se obtendría desnaturalizar el principio neutralizando su fortaleza principal, que es su capacidad de adaptarse a las más variadas situaciones humanas. ${ }^{381}$

En este orden de ideas, la flexibilidad de la buena fe, resulta binaria, por un lado le permite influir en las más diversas ramas del ordenamiento jurídico, actuando de distinto modo, según la materia de que se trate, y cumpliendo múltiples funciones, y por otro, le impide realizar una definición omnicomprensiva de lo que la buena fe es.

De los Mozos, señala que nadie puede agotar el significado de la buena fe por la variedad de su contenido, por el empleo múltiple que de él se hace por el ordenamiento jurídico, y porque se trata, en definitiva, de una norma abierta, de un verdadero estándar jurídico utilizado para responder a las necesidades del caso. ${ }^{382}$

Por lo afirmado, la conceptualización de la buena fe no puede establecerse en una definición sincrética, sino que estará dada por su asimilación con los valores que encarna y se identifican con ella. En todo caso, ello no debe derivar en una desfiguración del principio, pues con ello éste dejaría de tener toda aplicación práctica,

\footnotetext{
${ }^{381}$ En este sentido afirma Rezzónico: "Sería de alguna manera contradictorio afirmar, por una parte, que se está ante una norma abierta siempre posible de colmar con nuevas realidades, y por otra definir el instituto, que se remodela constantemente". REZZÓNICO, Juan Carlos, "Efecto expansivo de la buena fe" en La Ley 1991-C, p. 520.

${ }^{382}$ DE LOS Mozos, José Luis, El principio general de la buena fe ..., Ob. Cit. p. 21.
} 
transformándose en un término carente de todo contenido y utilidad jurídica.

Debemos entonces contentarnos con intentar dar luces acerca del contenido axiomático del principio, para poder identificar los momentos y circunstancia cuando estamos en presencia de éste.

b.- Contenido

La buena fe tiene un eminente contenido ético-social, ${ }^{383}$ que implica investigar y valorar las distintas circunstancias por la cuales un sujeto actúa. Este elemento no es creado por el Derecho, sino que utilizado por el ordenamiento jurídico para lograr sus fines. No obstante, cabe consultarse ¿cuál es la ética que el derecho tiene en consideración para valorarla?.

Wieacker, estima que no se trataría de una ética materialistanormativa de validez universal y atemporal, sino que se trataría de una ética eminentemente práctica-casuística, más cercana a la

\footnotetext{
${ }^{383}$ En la actualidad parece haberse superado la vieja disputa entre los que otorgaban un contenido psicológico a la buena fe, y otros que hacían prevalecer un contenido ético, prevaleciendo esta última concepción como correcta hoy por hoy. La concepción psicológica, encabezada entre otros por Wachter, sostenía que la buena fe es un hecho psicológico consistente siempre en una opinión, basada en una creencia errónea, sea de la naturaleza que fuere. De esta manera la buena fe constituía un simple error, valorado jurídicamente a favor del sujeto, sin tener en cuenta su valoración ética, es decir, con independencia de que el error sea o no excusable. Por su parte, la concepción ética, encabezada por Bonafante, considera la buena fe ya no como un puro estado psicológico, sino que se trataría de un estado ético. Esta noción es mucho más exigente, pues e sujeto que opera en virtud de un error o de una situación de ignorancia no es merecedor de la protección o de la exoneración de la sanción que se otorga al de buena fe, si su comportamiento no es valorado como el más adecuado conforme a la diligencia socialmente exigible.
} 
función social del Derecho y a su fundamento de validez. ${ }^{384}$ Ferreira Rubio, considera que hay que remitirse a las estimaciones de la sociedad en su conjunto pues el Derecho no esta dirigido a los jurista en exclusiva, sino a todos los miembros de la sociedad. ${ }^{385}$

Por su parte, Betti ${ }^{386}$ expone que cuando la legislación en sus diversas normas hacen alusión a la buena fe, se refiere a un concepto y a un criterio valorativo que no esta forjado por el Derecho, sino que éste lo sume y recibe de la conciencia social, de la cognición ética de la sociedad. La buena fe es concepto anterior al Derecho, éste esta llamado a integrarlo a su ordenamiento y a determinar las consecuencias prácticas que se derivan de su aplicación.

Así las cosas, la buena fe no es un concepto creado por la dogmática jurídica, sino que es una valoración de conductas tomadas de la realidad social intersubjetiva que está en la naturaleza de la persona. Por su intermedio el orden jurídico se oxigena y consolida, positivando criterios de conductas éticas que pasan a formar parte de él.

c.- Concreción

La buena fe en el campo del derecho pasa a ser un patrón de conducta, que se exige a todos los miembros de la comunidad

\footnotetext{
${ }^{384}$ WIEACKER, Franz, El principio general de la buena fe... Ob. Cit., pp. 34-36.

${ }^{385}$ FERREIRA RUBIO, Ob. Cit., p.131.

${ }^{386}$ BETTI, Emilio, Teoría general de las obligaciones, t.l., Revista de Derecho Privado, Madrid, 1969, p. 71 y ss.
} 
jurídica, en cuanto todos ellos, en todas sus actuaciones deben comportarse según los dictados que impone la buena fe, esto es, con corrección, lealtad, honradez y rectitud.

Saavedra, nos señala al efecto: "Actuar de buena fe implica comportarse conforme lo hace la gente honesta, con lealtad y rectitud, la buena fe impone a las partes, en sus relaciones recíprocas, un deber de honestidad, un obrar con sinceridad"387 Sobre este particular, Diez-Picazo ${ }^{388}$ nos indica que la buena fe es un concepto técnico acuñado por las técnicas del derecho y usado como descripción o delimitación en diferentes supuestos de hecho normativos. Por que sería un estándar o modelo ideal de conducta social, al igual que la remisión al deber de actuar con diligencian de un buen padre de familia o las buenas costumbres.

De lo que se sigue que al ser la buena fe un estándar jurídico como el de buen padre de familia, es necesario su concreción. La conducta debida no es de aplicación general, es decir, no es un comportamiento abstracto, sino que requiere la concreción por parte del intérprete. Se trata de un vector necesitado de precisión, que solo marca la dirección en la que hemos de buscar la contestación de la cuestión planteada, no nos marca una norma sino que exige buscar una solución para el caso concreto.

En cuanto a estándar jurídico la buena fe, se presenta como un concepto elástico y flexible, como una verdadera válvula o norma

\footnotetext{
387 SAAVEDRA, Francisco Javier, "El principio general de la buena fe" en Instituciones modernas de derecho civil, homenaje al profesor Fernando Fueyo Laneri, (Dir.) Enrique Pérez Levetzow, Editorial Conosur, Santiago, 1996, p. 357.

${ }^{388}$ DiEZ-PICAZO, Fundamentos...” Ob. Cit. p.13
} 
abierta, que consiste en un recurso del legislador, que encuentra en su falta de formulación concreta, una propia utilidad que permite conectar el orden jurídico con el cambiante entorno social sobre el que debe actuar. Esta indeterminación originaria del concepto de la buena fe, ha llevado a que para su concreción se tienda a precisar criterios prácticos de aplicación a través del reenvió de nuevos principios que se entiende derivados de la buena fe. La necesaria concreción al caso particular, dependerá de la naturaleza del vínculo de que se trate, de la situación de las partes, equilibrio económico y negociador.

En fin, dependerá en resumidas cuentas de la ponderación que haga el juez de las circunstancias del caso concreto conforme a lo que la experiencia jurídica y lo razonable le dicten. Luego del proceso de concreción en la aplicación de caso particular, la buena fe opera como un instrumento informador de la juridicidad en el ordenamiento, exigiendo de esta manera conductas tendientes al respeto de la fidelidad, corrección, lealtad, cooperación y confianza mutua en toda relación jurídica dada.

\section{3.- CLASIFICACIÓN}

Uno de los temas de mayor debate ha suscitado en la doctrina sobre este principio, se refiere a si éste es un concepto unitario, con distintas manifestaciones o si bien se debe hablar de dos aspectos claramente distintos, a saber uno subjetivo, de carácter psicológico, y otro objetivo como estándar de conducta. 
a.- Buena fe subjetiva

Resulta tradicional en el estudio de la buena fe, diferenciar por un lado, la buena fe que refiere a la creencia que tiene un sujeto de que la conducta empleada por éste es correcta, de las exigencias concretas de honradez, lealtad y rectitud. Esta noción subjetiva de la buena fe como creencia, es recogida por el Derecho romano apropósito del poseedor usucapiente, adquirente a non domino, en el pasaje de las Instituciones de Gayo 2,43 (Item usucapio nobis competit... cum crederemus eum qui traderet dominum esse). ${ }^{389}$

Para López Santa María, la buena fe subjetiva es la "convicción interna o psicológica de encontrarse el sujeto en una situación jurídica regular, aunque objetivamente no sea así, aunque haya error". ${ }^{390} \mathrm{El}$ Derecho ampararía a quien, pese a encontrase en una situación jurídica objetivamente irregular, posee la convicción interna de encontrarse en una situación licita. La buena fe, aparece aquí como una noción justificativa del error.

Por su parte De los Mozos, ${ }^{391}$ indica que esta faz subjetiva, se presenta como la creencia del sujeto sobre la propia situación o sobre la situación de la persona con quien se relaciona. Así alude a la correcta situación del sujeto dentro de la relación jurídica, y no al

\footnotetext{
389 SANSÓn RodRígueZ, María, "La buena fe en el cumplimiento de las obligaciones contractuales en el Derecho romano clásico. Especial referencia al problema de la bilateralidad en los contratos consensuales" en AFDUL, núm. 18, 2001, p. 37.

390 LÓPEZ SANTA MARÍA, Jorge, Los contratos, Parte general, t. II. Editorial Jurídica de Chile, $2^{\mathrm{a}}$ ed., Santiago, 1998, p. 392.

${ }^{391}$ DE LOS Mozos, El principio general de la buena fe...", Ob. Cit., p. 57.
} 
contenido o efectos de la relación misma. En cambio para Fueyo, ${ }^{392}$ la buena fe subjetiva es el estado de consciencia que produce la convicción de que estoy procediendo correctamente y conforme a derecho siendo la realidad otra diferente.

En síntesis, la buena fe subjetiva se refiere al estado psicológico del que se cree estar en una situación regular o actuando correctamente y en realidad no lo esta. Supone una representación errada de la realidad, una ignorancia, una creencia errónea excusable, un ejemplo de esta faz de la buena fe es el poseedor de la buena fe. La creencia, desde el punto de vista del que cree, es razonada, fundada en atención a los elementos de juicio a su alcance.

El Derecho, protege al que cree razonablemente en la apariencia que inspiró su confianza. Lo que pondera la buena fe subjetiva es la situación del sujeto que actúa, no se valora una norma de conducta sino el estado de conciencia o creencia del sujeto con referencia a su propia situación o la ajena, lo que hace finalmente que el Derecho lo ampare excluyendo el carácter ilícito de sus actos en algunos casos o justificándolos en otros.

b.- Buena fe objetiva

Como contrapartida a la faz subjetiva, se encuentra la buena fe objetiva, prescindiendo de todo aspecto psicológico del sujeto, para

\footnotetext{
${ }^{392}$ FUEYO LANERI, Fernando, Instituciones del Derecho Civil moderno, Editorial Jurídica de Chile, Santiago, 1990, p.148.
} 
centrarse en el campo de las conductas y la ética. De este modo, la buena fe objetiva se nos presenta como una regla de conducta humana que exige dirigir el actuar conforme a una serie de normas de configuran patrones de rectitud y honestidad.

De los Mozos, ${ }^{393}$ afirma que uno de los aspectos más intensos de la aplicación del principio de la buena fe se encuentra en sus proyecciones a través de la buena fe objetiva, teniendo especial desarrollo en el derecho de obligaciones y en la teoría general del negocio jurídico. En estos casos la buena fe como comportamiento de fidelidad se sitúa en el mismo plano que los usos o la ley, es decir, adquiere función de una norma dispositiva, de aquí emana su naturaleza objetiva, pues, no depende de la voluntad sino del alcance de una norma.

La buena fe objetiva opera como modelo de conducta social debida, al cual se debe adaptar el comportamiento de la persona que integre la relación jurídica. Es una norma que impone un deber de fidelidad, lealtad, honestidad, probidad y cooperación. Se parte de la base que no se debe aprovechar indebidamente del otro en su debilidad o en su desconocimiento.

La buena fe objetiva impone conductas desde una óptica negativa como positiva. Desde el punto de vista negativo, exige vetar y abstenerse de toda conducta deshonesta que implique alguna posibilidad de daño. En cambio desde la óptica positiva, exige actuar con diligencia, cooperación, solidaridad.

${ }^{393}$ De Los Mozos, El principio general de la buena fe...”, Ob. Cit., p. 45 - p. 57. 
La buena fe en su faz objetiva, comporta un deber de conducta impuesto al sujeto con base en una justificación ética o de justicia, siendo necesario ponderar el dolo o la culpa del sujeto. Así, quien actúa con culpa o dolo no puede luego invocar la buena fe. En definitiva, la buena fe objetiva nos obliga a pensar en la protección de los derechos del otro.

c.- Concepción unitaria.

En nuestra opinión la buena fe debe ser comprendida como una noción o concepto unitario, aún cuando esta cumpla variadas funciones dentro del ordenamiento jurídico. Por cuanto, todas sus manifestaciones encuentran su origen en el mismo principio y comparten la misma naturaleza ontológica. Así, tanto él que actúa ignorando la realidad o creyendo en lo aparente, asume el deber de actuar objetivo proyectado en el respeto de una norma, como él que despliega su actividad dentro de la relación obligacional, también supone una valoración subjetiva de esa conducta.

Hernández Gil, señala que la buena fe incorpora un significado que le es siempre inherente, del cual la ley puede hacer especificaciones y aplicaciones, pero sin que en ningún caso pueda resultar excluido o negado. ${ }^{394}$ Para De los Mozos, no existen dos clase de buena fe, sino que ésta es bifronte, o sea, la buena fe subjetiva (creencia) y la objetiva (confianza) son dos aspectos del mismo

\footnotetext{
${ }^{394}$ HeRnández GIL, Antonio, Conceptos jurídicos fundamentales, Obras completas, t. I. Espasa-Calpe, Madrid, 1987, p. 561.
} 
concepto. Cuando se protege o se exige actuar de buena fe, está en juego la creencia, una confianza de la persona con evidente carácter ético. ${ }^{395}$

La buena fe incorpora, en todas sus aplicaciones, una unidad de significación, sin importar la diversidad de los presupuestos sobre los que se establezca. Esta significación es eminentemente ética y, por lo tanto, a su vez valorativa y normativa, luego, ésta unidad surge del hecho de que la buena fe es un patrón de conducta, ella siempre actúa como una pauta de un comportamiento con prescindencia de sus fases o momentos.

Si entendiéramos lo contrario, caeríamos en el sinsentido de aceptar que la buena fe subjetiva se aplicaría tan solo a materias particulares como las relativas a derechos reales y de familia, y la buena fe objetiva quedaría reducida tan solo al derecho de obligaciones. Ello, evidentemente es una antinomia inadmisible, por que importaría limitar -impropiamente- el actuar de la buena fe, yendo en contra de su propia naturaleza de principio general de derecho.

En definitiva, la buena fe es un arquetipo o molde de conducta debida y exigible tanto al ejercer un derecho como al cumplimiento de una obligación. Este modelo se concreta en el deber de lealtad y respeto de lo acordado, en asumir un proceder honesto y diligente, y en no defraudar la confianza de los demás ni abusar de ella.

\footnotetext{
${ }^{395}$ De Los Mozos, José Luis, "Buena fe", en Enciclopedia de la Responsabilidad Civil, Buenos Aires, 1996, p. 789.
} 
Cuando la globalización y el avance apresurado de la tecnología parecen desbordar la idea típica del contrato, lo único que mantiene firma la vigencia plena del éste, es su fidelidad al principio de la buena fe.

III.- Buena fe contractual: Fuente inmediata del deber de PROTECCIÓN

Una crítica que se le efectúa repetidamente a nuestro objeto de estudio, es la frágil fundamentación dogmática que justifica la inclusión de dichos deberes en la orbita contractual.

Un ejemplo de lo anterior, es aquella opinión que señala que los deberes de protección son solo un producto del forzamiento del contrato, y que en virtud de una interpretación muchas veces adivinatoria de la voluntad de las partes, se extraen tales deberes para complementar caprichosamente la convención, lo que resulta del todo artificioso. 396

Lo cierto, es que, tal postura desconoce el hecho fundamental, de que la sede de los deberes de protección no se encuentra en la voluntad de las partes, sino que la propia ley, que vincula al contrato todas las consecuencias que el principio general de la buena fe da a la obligación de acuerdo a la naturaleza del propio contrato.

\footnotetext{
${ }^{396}$ En realidad, reflexiona Josserand, la obligación de seguridad no tiene nada de convencional, se trata de una imposición legal o más bien jurisprudencial, sin dudas "hypothétique et divinatoire" Véase, HOCQUET-BERG, Ob. Cit., p. 257. En el mismo sentido: JouRdAIN, L'obligation de sécurité...» Ob. Cit. p. 1214.; MAZEAUD Henri, Jean y León, ChABAS, Francois, Derecho civil. Obligaciones, t. I, trad. Luis Zavalia, Buenos Aires, 1997, p. 517
} 
Ya hemos tenido la oportunidad de señalar, en nuestro estudio, la idea de que los deberes de protección se integran a la relación obligatoria por medio de la buena fe. No obstante, tal aseveración resulta imprecisa, si no se tiene en cuenta, el como y bajo que supuestos del iter contractual se efectúa.

En consecuencia, para dar por descontado la aplicación de la buena fe como fundamento normativo directo, es necesario indagar sus fuentes, funciones y su interconexión el fenómeno de los deberes de protección.

1.- ANTECEDENTES DE LA BUENA FE CONTRACTUAL

Para comprender de mejor manera, la asimilación de la buena fe contractual como una verdadera norma impositiva en el ordenamiento jurídico, revisaremos en líneas muy generales, los precedentes de la buena fuente contractual, en su inicios en Roma y en su posterior configuración en el proceso de nacionalización del Derecho en el fenómeno codificador.

a.- Origen en Roma

Ya tuvimos la oportunidad de analizar someramente la evolución de la bona fides en la tradición romana y posterior recepción 
de ella por el Derecho común. Ahora nos referiremos a la especial relación existente entre la bona fides y el contrato en Roma, por cuanto, -como se verá- su desarrollo y aplicación serán recogidos por el Derecho contemporáneo.

En Roma, se distinguían los contratos según contenían o no la obligación de ejecutarlos de buena fe..$^{397}$

De este modo, por un lado existían los stricti juris negotia, en los cuales las partes debían atenerse exclusivamente a lo acordado y el acreedor sólo podrá exigir del deudor lo que éste "estrictamente" prometió, sin que el juez puede añadir ni quitar nada, aunque ello chocase muchas veces con los principios elementales de la equidad.

Este tipo de contractual, era propio del Derecho quiritario romano, donde el formalismo y ritualismo ocupaba parte importante del tráfico jurídico. Así, en el contrato de mutuo (de derecho estricto), el mutuante (acreedor) sólo podrá pretender del mutuario (deudor) estrictamente la devolución de la cantidad prestada, pero no podrá exigir el pago de intereses o una congruente indemnización en caso de mora, si no se hubiese pactado expresamente. ${ }^{398}$

En el lado contrario, se encontraban los contratos bona fides negotiae, los cuales, obligaban no solo a lo que en ellos se hubiese estipulado expresamente, sino, que además engendraban

\footnotetext{
${ }^{397} \S$ CCXLIV. Ins. 4, 6, § 28, 32, Bonae Fidae,Strictae Et Arbitrarie Actiones, GuSTAV, Hugo, Historia del Derecho Romano, trad. Manuel Casado Tello, Madrid, 1850, pp. 283-284.

${ }^{398}$ ZIMMERMANN, Ob. Cit, pp. 660 y ss.; También en MousouRAKIS, George, Fundamentals of Roman Private Law, Springer Science \& Business Media, Auckland, New Zealand, 2012, pp.190 y ss.
} 
obligaciones indeterminadas cuya fuente era precisamente la bona fides, son por ejemplo los contratos de sociedad, comodato, mandato.

Guzmán Brito, afirma que en el Derecho clásico la bona fides, vinculaba a las partes de un contrato no solo a las obligaciones expresadas en él por aquellas, sino más, precisamente a lo exigido por la buena fe, agregando que en Derecho romano clásico, la concreción de lo "más" que lo expresado en el contrato a que la buena fe deja obligadas a sus partes quedaba entregadas a la libre apreciación del juez, (ex fide bona officium iudicis). ${ }^{399-}$

Las acciones que contenían la cláusula ex fide bona son llamadas en las Instituciones de Gayo 4, 62, iudicia bonae fidei, que se contraponían a las que los que en la última etapa del Derecho romano llegaron a llamarse iudicia stricta.

Esta noción ya aparece en Cicerón, incluida dentro de los arbitria bonae fidei los derivados de la tutela, de la fiducia entre ciudadanos y de la sociedad, el mandato, la compraventa y el arrendamiento (Cicerón. De officcis. 3,17,70). En la enumeración de los iudicia bonae fidei, efectuada Gayo, figuran además de las acciones que protegen los contratos consensuales, de la actio fiduciae y de la actio tutelae, las acciones derivadas de la gestión de negocios ajenos, y la del depósito. ${ }^{400}$

\footnotetext{
399 GuZMÁn BRITo, Alejandro, "La buena fe en el Código Civil de Chile", en Revista chilena de Derecho, vol. 29, núm. 1, Santiago, 2002, pp. 82-83.

${ }^{400}$ SANSÓn ROdRíguez, Ob. Cit., p. 40.
} 
Los iudicia bonae fidei contenían la cláusula «quidquid ob eam rem Numerium Negidium Aulo Agerio dare facere oportet ex fide bona» (Gayo 4, 47), que permitía al juez en el procedimiento formulario sentar la exigibilidad del cumplimiento de las obligaciones de las partes y sus efectos conforme a la buena fe objetiva, esto es, conforme con lo que es exigible entre lo que la sociedad considera personas justas y leales, patrón que solo es entendible por el rechazo de conductas a él contrapuestas, y que obliga al juez a eliminar la exigibilidad del cumplimiento de obligaciones obtenidas a través de conductas engañosas, deshonestas y desleales sin necesidad de recurrir a la inserción en la fórmula de una exceptio doli en favor del demandado.

También la buena fe permite al juez exigir su cumplimiento en caso de que la otra parte dolosamente haya propiciado la imposibilidad de exigirlo (por ejemplo obteniendo dolosamente del demandante un pacto de no pedir). ${ }^{401}$

No queda claro, si el origen de los iudicia bonae fidei es de fuente civil o pretoria, pues, no se basan en una cláusula edictal y su fórmula alude a un «oportere» ex fide bona, pero para la opinión mayoritaria su origen seria pretorio, pues los pretores habrían abierto la puerta del proceso a relaciones que eran ya reconocidas por normas morales y sociales asentadas inspiradas en la bona fides y que habían sido recibidas en el mundo jurídico a través de la costumbre.

También resulta confuso, admitido su origen pretorio, si su introducción se debe al pretor urbano o al pretor peregrino, aunque la

\footnotetext{
${ }^{401}$ CARCATERra, Antonio, "Ancora sulla fides e sui bonae fidei iudicia», en SDHI, XXXIII, 1967, p. 65 y ss.;
} 
opinión más común se inclina a entender que su origen está en el ius gentium, pues el pretor peregrino insertaría en el ius gentium normas parajurídicas, que regulaban las relaciones entre romanos y peregrinos, y que habían surgido por la costumbre en el comercio internacional, de facto y también como consecuencia de decisiones arbitrales. ${ }^{402}$ La influencia del ius gentium, introdujo nuevas formas contractuales más laxas, desprovistas de los formalismos y ritos clásicos romanos. ${ }^{403}$

El uso de los contratos protegidos por la iudicia bonae fidei, trajo innegablemente diversas consecuencias en el mundo romano, por ejemplo, los pactos accesorios (pacta adjecta in continente) serán siempre exigibles cuando figuren en contratos de buena fe..$^{404}$

Otra consecuencia especialmente distinguible, se encuentra en la en la amplitud de apreciación judicial que existía en los contratos bonae fidei. Así en los contratos stricti juris negotia, si una de las partes, al celebrar el contrato, envuelve a la otra en fraude, el juez no tenía otra posibilidad de fallar a favor del demandante, por que el dolo no invalidaba el negocio, ya que las excepciones -incluso las fundadas en la ley- debían ser expresamente solicitadas por el demandado e insertadas en la fórmula procesal. ${ }^{405}$

\footnotetext{
402 TALAMANCA, Mario, «La tipicità dei contratti romani fra 'conventio' e 'stipulatio' fino a Labeone», en Contractus e pactum, Atti del convegno di diritto romano e della presentazione della nuova riproduzione della littera Florentina, a cura di F. Milazzo, Napoli 1990, p. 44.

${ }^{403}$ Un posible antecedentes lo encontramos en Jurista Paulo: "Debe por naturaleza el que por derecho de gentes debe dar y a cuya fe nos atuvimos". Paulo, Digesto, libro XVII, párrafo 84. Véase, CARAmÉs FERRO, José, Curso de Derecho Romano, Buenos Aires, 1958,

${ }_{404}^{\text {p. } 53 .}$ SANSÓN RODRÍGUEZ, Ob. Cit. p. 41.

${ }^{405}$ De ello encontramos testimonio en Cicerón, quien en su texto de officis. 3, 14, 58, hace referencia al contar la historia de Cannio que es engañado por Pizzio, un banquero de Siracusa. En efecto relata, Pizzio, aprovechándose de interés de Cannio en adquirir una villa
} 
Mas ello, no regía en los iudicia bonae fidei, en los cuales se entendían deducidas todas las excepciones posibles que el demandado pudiera hacer valer, sin necesidad de su mención expresa en la fórmula, de modo que bastaba alegarlas ante el juez. ${ }^{406}$ Por ende, si el deudor se veía favorecido por alguna ley u otra norma, de modo de poder fundar una exceptio en ella, la buena fe del contrato le permitía alegar esa ley o norma directamente al juez sin necesidad de haber insertado previamente la alegación como exceptio en la fórmula. En este sentido, pues, la vinculación a cualquier consecuencia legal alegable estaba directamente incluida en la buena fe..$^{407}$

No obstante, la más destacable consecuencia se encuentra en la "diligencia" que los bonae fidei exigían a las partes del contrato. En los contratos stricti juris negotia, solo se obligaba a abstenerse de actos perjudiciales, es decir, culpa lata o grave, mientras que en los contratos protegidos por la iudicia bonae fidei, en cambio se obligaba a desplegar la diligencia necesaria para el cumplimiento del contrato $y$, tratándose de obligaciones que recaigan sobre cosas, a velar por su indemnidad y conservación. En el pensamiento clásico, la falta de

en esos parajes, monta toda una trama con ayuda de sus amigos, a fin de hacerles creer que la costa sobre la que está situada su villa es pródiga en pesca. Cannio, convencido engañosamente de tales bondades, suplica a Pizzio que le venda la villa, la cual paga un precio considerable. Sin embargo, al día siguiente se encuentra con la desagradable sorpresa de que allí no hay tal abundancia de pesca. No obstante lo evidente del engaño, Cicerón resalta que nada puede hacerse respecto a la validez de contrato, porque en aquella época no habían sido promulgadas las normas sobre fraude que fueron obra luego de Aqulio Gallo.

${ }^{406}$ D. 2, 14, 7, 6. La buena fe en esta materia funcionaba del siguiente modo: Si el deudor puede alegar una excepción y no la insertó en la fórmula, es contrario a la buena fe que el acreedor rechace la alegación aduciendo que no fue insertada como excepción. De lo que se sigue que aquella no se necesita ser insertada como excepción, ("bonae fidei judicilis doli excepcio est").

407 GuZMÁn BRITo, “La buena fe en el Código ...” Ob. Cit., p. 15. 
diligencia constituía una ruptura intencional de la fides, efectivamente, esta estrecha relación entre bona fides y diligencia ha sido expresamente plasmada en las fuentes, ${ }^{408} \mathrm{y}$ en particular en el texto de Celso. ${ }^{409}$

Por último, resulta singularmente destacable, que después de toda su evolución jurídica, el paso del tiempo y las trasmutaciones científicas y metodológicas, no han podido perturbar el sentido original de la idea de buena fe basada en la confianza y la lealtad. Ni mucho menos han podido menoscabar su sitial de relevancia en las relaciones sociales y jurídicas. ${ }^{410}$

Así, con la llegada la modernidad, se recogerán estas manifestaciones, asimilándolas al Derecho contemporáneo. Su reconocimiento positivo se encontrará por primera vez en los artículo 1134 inciso $3^{\circ}$ y 1135 del Código de Napoleón, que establecerán de modo general, que las convenciones deber ser ejecutadas de buena fe.

\footnotetext{
${ }^{408}$ D, 40.7.21, PomponiO. Doctrina de Plaucio, libro VII: "Labeón dice así en el libro de los Posteriores: sea libre Caleno, mi administrador, y tenga todo lo suyo, y la suma de cien, si se ve que llevó diligentemente las cuentas; debemos desear aquella diligencia que fuere útil al señor, no la que al esclavo; más irá unida a esta diligencia la buena fe no solamente en la ordenación de las cuentas, sino también en la devolución de los remanentes". D.18. 1. 68, PRÓculo, Epístolas, Libro VI: "Si cuando vendieses un fundo hubieses dicho en un pacto, que lo que hubieses cobrado del arrendatario a título de arrendamiento habrá de corresponder al comprador, opino que en la cobranza debes responder no solo de la buena fe, sino también de la diligencia, esto es, no solamente de que estas exento de dolo malo, sino también de culpa."

${ }^{409}$ D. 16. 3. 32 CELSO. Digesto, Libro XI: "Lo que decía Nerva, que es dolo una culpa más lata, y no parecía bien a Próculo, a mí me parece muy verdadero. Por que también si alguno no es diligente de la manera que requiere la naturaleza de los hombres, sin embrago, si a su modo no pone cuidado en el deposito, no carece de fraude; porque con buena fe no podrá en aquellas menor diligencias que en sus cosas propias."

${ }^{410}$ GonzÁlez MÉndez, Amelia, Buena fe y Derecho tributario, Marcial Pons, Madrid, 2001, p. 24.
} 
b.- Codificación

El proceso de la codificación concretó las manifestaciones de las iudicia bonae fidei, fijándolas directamente como exigencias de la ley. ${ }^{411} \mathrm{De}$ esta manera, en los códigos modernos, el ámbito de aplicación general de la buena fe es enriquecido como efecto de su generalización a todos los contratos. ${ }^{412}$

El Código francés, precedido de no escasos intentos fallidos ejecutados en la época de la revolución, ${ }^{413}$ vio la luz en 1804 . En lo referido a la buena fe contractual, quedará consagrada en el Code en los artículos 1.134 inciso $3^{\circ}$ y 1.135 . El citado inciso $3^{\circ}$ dispone: "Elles [SC. les conventions] doivent étre exécutées de bonne foi". Por su parte, el artículo 1.135 señala: "Les conventions obligent non seulement à ce qui y est exprime, mais encore à toutes les suites que

\footnotetext{
${ }^{411}$ Con codificación nos referimos, al proceso de codificación civil iniciado post revolución francesa, ya que, el concepto de codificación en la historia a aludido a los más fecundos productos claramente diferentes y heterogéneos, o que puede suscitar más de alguna perplejidad. A Saber por ejemplo: Código de Hammurabi (1700 a. C), Codex Justianianus (539) entre otros. Sobre la noción y concepto de Codificación, Véase, CARONI, Pio, Lecciones de Historia de la Codificación, Dykinson, Madrid, 2013.

${ }_{412}$ No obstante, desde un punto de vista de sus aplicaciones particulares, quedo empobrecida, debido a la técnica legislativa que las reguló directamente. Tal fue el caso de la responsabilidad contractual por dolo y culpa; de la obligatoriedad de los pactos agregados a un negocio principal, de la ilicitud de condonar anticipadamente el dolo, de la reparación no solo del daño emergente mas también del lucro cesante, vale decir, un enfoque central en el interés del acreedor, de la indemnización de perjuicios causados por la mora (que también es parte de este interés), de la compensación de obligaciones mutuas. GUZMÁN BRITO, "La buena fe en el Código...", Ob. Cit., p. 14.

${ }_{413}$ Dicha labor marcho bajo mejores augurios cuando fue asumido por el primer cónsul Bonaparte, quien por decreto de 24 de Thermidor del año VIII (12 de agosto de 1800), designó una comisión para deliberar acerca de la formación del código civil, integrada por Françoise Denis Tronchet, Jean-Étiene-Marie Portalis y Félix-Julien-Jean Bigot de Preameneu, a la debía ser convocado Jacques de Maleville como secretario redactor. Esta comisión excedió el acotado objeto que se le encomendó y elaboró un proyecto completo que el 1 de Pluvioso del año IX (21 enero de 1801) el presidente Trochet entregó al primer cónsul Bonaparte. Él se iniciaba con el livre préliminaire y se desarrollaba a lo largo de sucesivos tres libros numerados, que conocemos por el nombre de "Project de l' an VIII'.Véase, GuZMÁn BRITO, Alejandro, Codificación del Derecho civil e interpretación de las leyes, llustel, Madrid, 2011, pp. 365-366.
} 
l'étquité, l'usage ou la loi donnent à l'obligation d'aprés sa nature". Estas disposiciones que servirán de fuente directa o indirectamente a los demás Códigos civiles, tienen claro asidero en el efecto que la bona fides del Derecho romano introdujo en materia contractual.

Los artículos en comento, encuentran su fuente en el pensamiento de Jean Domat, quien expone en su obra "Les loix civiles dans leur ordre natural"' de $1689,{ }^{414}$ en relación a la buena fe contractual lo siguiente: "Les loix civiles dans leur ordre naturel que, "les conventions obligent non seulement à de qui y es exprimé, mais, encore à toutes les suites ce que l'equité, l'usage ou la loi donnet à l'obligation d'apreés sa nature."

En Domat, se encuentra la idea de que la buena fe deberá regir no solo en la ejecución sino también en la formación e interpretación de todos los contratos. Este autor, recuerda que en el Derecho romano se distinguían contratos stricti juris negotia y los contratos bonae fidei negotia, sosteniendo que en el derecho francés son todos de buena fe. ${ }^{415}$

En el Code, atendido que la buena fe de las convenciones aparece declarada como principio absoluto e incondicionado en el artículo 1.134 inciso $3^{\circ}$, la buena fe deberá operar aparentemente como el Derecho romano, vale decir, entregada a la libre apreciación del juez. ${ }^{416}$

\footnotetext{
${ }^{414}$ Domat, Jean, Les Lois civiles dans leur ordre natural, en Le Droit public et legum delectus, Paris, chez Th. De Hansy, 1735, I

${ }^{415}$ Véase, García Amigo, Manuel, "Consideraciones a la buena fe contractual", en Homenaje al profesor Bernardo Moreno Quesada, vol. I, Granada- Jaén- Almería, 2000, pp. 615 y 616., también en ORDOQUI CASTILLA, Gustavo, Buena fe contractual... Ob. Cit., p. 138 ${ }^{416}$ Pothier, no escribió ningún tratado particular sobre las fuentes del Derecho ni sobre la leyes y su interpretación. Acerca de estos temas, se había limitado a ordenar los
} 
Pero si lo característico de la buena fe, y real efecto es precisamente dejar a las partes sujetas a más consecuencias que las obligaciones expresadas en el contrato, cuando verificamos que precisamente eso aparece declarado en el artículo 1.135, resulta entonces que el libre oficio del juez en materia de buena fe, viene reenviando al marco que señala el artículo antes citado.

En él se impone, por una parte, una limitación, pues el campo de obligaciones que sujetan a las partes más allá de lo que expresaron en su contrato, queda circunscrito a "à toutes les suites [...] l'usage ou la loi donnent à l'obligation d'aprés sa nature." Decíamos en parte, porque de la misma manera que se comprime, se amplia por otro lado, pues, las "suites" señaladas en el artículo en comento, también pueden provenir de la "equite". 417

Es poco dudoso, entonces pensar que los codificadores franceses, tomaron estas ideas del Derecho romano también. Por lo que respecta a la equidad tenemos, en efecto D. $16,3,31$, pr. (Triphon., 9 disput) "Bona fide, quae in contractibus exigitur simman desiderat." En lo concerniente al uso, D. 21, 1, 31, 20 (Ulp., 1 ed. aed, cur) "...ea enim, quae sunt moris et consuetudinis, is bonae fidei iudiciis debent venire." 418

pertinentes fragmentos de los Digesta y del Codex de Justiniano en su Pandectae (17481752). GuZMÁn BRITO, Codificación del...” Ob. Cit., p. 367.

${ }^{417}$ GUZMÁn BRITO, "La buena fe en el Código ...." Ob. Cit., p. 15.

${ }^{418}$ GuZMÁN BRITo, "La buena fe en el Código ...." Ob. Cit., p. 15. 


\section{i.- Código Civil Español}

En España, el movimiento codificador aunque tardío, no supuso al igual que en otros lugares la ruptura del orden jurídico anterior y el establecimiento de uno nuevo. Por el contrario, este movimiento proclamó expresamente el mantenimiento del sentido y capital pensamiento de las instituciones civiles del Derecho histórico. ${ }^{419}$

En este orden de ideas, al igual que el resto de los Códigos Civiles modernos, recibirá la influencia de su antecesor francés, por lo que entendemos reproducido aquí, todo el debate mencionado respecto al Code y sus fuentes en materia de la buena fe. No obstante, dado la época de su promulgación, tal influencia fue recibida con más de algún matiz y nota disonante al respecto.

Así, el antecedente inmediato del Código Civil de 1889 no será el Code, sino, el proyecto de García Goyena ${ }^{420}$ Este proyecto de

\footnotetext{
${ }^{419}$ LÓPEZ MOZO, Jerónimo, II Notas Criticas: "La conservación de los regímenes forales y las leyes anteriores al Código civil," en Anuario de Derecho Civil, fascículo I, Madrid, 1951, p. 182-189.

${ }_{420}$ La elaboración del Código se acomete seriamente con la creación de la Comisión General de Códigos por el Real Decreto de 1843, que remitirá al Gobierno en 1851 el Proyecto de Código civil. García Goyena fue elegido presidente de la sección civil, formada además por Luzuriaga, Vila, Ruiz de la Vega, Vizmanos, Ortiz de Zúñiga, Álvarez, Escriche y De Quinto. Esta sección civil de la Comisión General de Códigos redactó un anteproyecto parcial (Libro I, Personas y familia; Libro II, Derechos reales) que se detuvo cuando, en julio de 1846, la Comisión se suprime. Estaba ya entonces bastante avanzada la elaboración de la Parte general de obligaciones y contratos. Meses después, reconstituida la Comisión, Bravo Murillo, García Goyena y Luzuriaga revisan lo hecho hasta entonces y completan la parte pendiente del Derecho de obligaciones y contratos. Se llevarían a término igualmente las partes restantes. Tras discusiones detalladas y numerosas sesiones de trabajo, la primera redacción del Proyecto se entregó al Ministro de Justicia en septiembre de 1849, pero el trabajo fue completamente revisado de nuevo a lo largo del año siguiente. Finalmente, el Proyecto fue elevado al Ministro de Gracia y Justicia el 5 de mayo de 1851. Véase, GAYA SICILIA, Regina "La influencia del código Civil de Luisana en la Codificación civil española." en Anuario de Derecho Civil, tomo LXIII, fascículo II, Madrid, 2010, pp. 728732
} 
1851, imprimirá un hito en la historia de la codificación civil española. Tal y como lo reconoce la base $1^{\text {a }}$ de la ley que autorizó al Gobierno la publicación de un Código Civil: "El Código tomará por base el proyecto de 1851 en cuanto se halla contenido en éste el sentido y capital pensamiento de las instituciones civiles del derecho histórico patrio, $[\ldots]^{3421}$

García Goyena, en diversas ocasiones de su vaivén político e institucional, advirtió de la necesidad de la codificación en España, un ejemplo trascrito de ello, es su discurso de inauguración del año judicial de la Audiencia Territorial de Burgos en 1836: "El caos y el laberinto de nuestra inmensa legislación, hija de todos los tiempos y de todas las formas de gobierno, será muy pronto reemplazado por la claridad y el orden, por Códigos adaptados á las luces y necesidades de la generación presente, y en armonía con el sistema liberal representativo que se empieza a establecer. ${ }^{\text {,422 }}$

El Proyecto de 1851 consta de 1992 artículos y sigue al Código civil francés, tanto en su sistema y orden de materias (con alguna leve modificación) como en el contenido -e incluso en la literalidad- de muchos de sus preceptos. Así, por ejemplo, ocurre con el consejo de familia y el protutor (art. 172, 190 ss.), el testamento ológrafo (art. 564), la transmisión de la propiedad sin necesidad de tradición (art. 981). Se estima que un 65 por ciento de los artículos del vigente Código Civil de 1889 están de inmediata relación con los del Proyecto

\footnotetext{
${ }^{421}$ Ley de Bases de 1 de mayo de 1888, autorizando al Gobierno para publicar un Código Civil, con arreglo a las condiciones y bases que se establecen en esta ley. Véase, GAYA SICILIA, Regina "La influencia del código Civil de Lusiana en la Codificación civil española... Ob. Cit., p. 730.

${ }_{422}$ Discurso Florencio García Goyena, 12 de enero de 1836, Burgos, Imprenta de Aranáiz, 1836, p.13.
} 
de $1851,{ }^{423}$ y que otro 10 o 25 por ciento, si bien suponen modificaciones importantes o radicales, "sigue teniendo su punto de partida en un precepto isabelino, que sirve todavía para dar cuenta de su intento y significado."${ }^{224}$

En lo que respecta al principio de buena fe contractual, el paradigma anterior se cumple a entera cabalidad, toda vez, que el actual artículo 1258 del Código Civil español, contiene literalmente el precepto del articulo 978 del Proyecto de Goyena, que señala: "Los contratos se perfeccionan por el mero consentimiento; $y$ desde entonces obligan, no solamente al cumplimiento de lo expresamente pactado, sino también á todas las consecuencias que, según su naturaleza, son conformes á la buena fé, al uso ó á la ley." ${ }^{, 425}$

A su vez, el artículo 978 tuvo como fuentes directas, -según relata el propio Goyena-, a los artículos 1135 del Código francés, 1089 del Código napolitano, 1226 del Código sardo, 836 del Código Vaud, 1897 y 1898 de Código de Luisiana y 1375 del Código holandés. También Goyena, hace alusión a las in bonae fidei judiciis, citando la ley 31 , párrafo 20 , título 1 , libro 21 del Digesto. ${ }^{426}$

El Código civil español vigente, impulso fuertemente el principio general de la buena fe, a través de la reforma llevada a cabo al Título preliminar, por la Ley de Bases de 17 de marzo de 1973 y el texto articulado, aprobado por Decreto de 31 de mayo de 1974,

\footnotetext{
${ }^{423}$ GAYA SICILIA, Ob. Cit., p. 733.

${ }^{424}$ LACRUZ BERDEJO, José Luis, "Las «concordancias» de García Goyena y su valor para la interpretación del Código civil" en Revista Crítica de Derecho Inmobiliario, marzo-abril, núm. 501, 1974, p. 293.

${ }_{425}$ GARCía GoYenA, Florencio, Concordancias; motivos y comentarios del Código Civil español, Imprenta Soc. tipográfico, Tomo III, Madrid, 1852, p. 8.

${ }^{426}$ García GoYenA, Ob. Cit., p. 9.
} 
introduciendo un precepto general de remisión al criterio de la buena fe, según el cual: "Los derechos deberán ejercitarse conforme a las exigencias de la buena fe" (art. 7.1). Es obvio que desde la promulgación del Código civil español en 1889, la buena fe, fue cobrando una importancia trascendental como principio general del Derecho, sin embargo fue la positivización de ésta como cláusula general en el art. 7 -siguiendo los modelos alemán y suizo- lo que provocaría su impulso decisivo, con la recepción de las orientaciones jurídicas más avanzadas del Derecho privado europeo.

Para Hernández Gil, sin embargo, la reforma del Título preliminar no produjo mayores cambios, sino que solo recogió los frutos jurídicos de las décadas anteriores; $y$, con respecto a la buena fe, su positivización no alteró su carácter de principio general. ${ }^{427}$ En una línea análoga, De los Mozos considera que "el artículo 7.1 no hace más que generalizar lo que establecen, por ejemplo, los arts. 1.258 del C.c. y 57 del C.com., y reconocer lo que era aplicable al ejercicio de todo derecho, por el mero juego del principio, universalmente admitido, por otra parte, como principio general del Derecho." ${ }^{" 28}$

\section{ii.- Código Civil Chileno}

\footnotetext{
${ }^{427}$ HeRnándeZ GIL, Antonio., "La posesión como institución jurídica y social”, en Obras completas, vol. 2, Madrid, 1987, pp. 153-154.

${ }^{428}$ DE LOS Mozos, José Luis, "La buena fe en el Título preliminar del Código civil", en Derecho civil. Método, sistemas y categorías jurídicas, Madrid, 1988, p. 226
} 
En materia de la buena fe contractual, ${ }^{429}$ el Código contiene una norma de valor general en su artículo 1546: "Los contratos deben ejecutarse de buena fe, y por consiguiente obligan no solo a lo que en ellos se expresa, sino a todas las cosas que emanan precisamente de la naturaleza de la obligación, o que por la ley o la costumbre pertenecen a ella."

Esta disposición aparece ya así en el "Primer Proyecto" (es decir, en el que conoció la Comisión Codificadora de 1840), como artículo 8 del título $\mathrm{XI}$ del libro De los contratos y obligaciones convencionales, y permaneció inmutado y vigente hasta nuestros días. $^{430}$

El artículo 1546 se inspiró en los artículos 1.134 inciso $3^{\circ}$ y 1.135 del Code. Así, el citado inciso $3^{\circ}$ dispone: "Elles [SC. les

\footnotetext{
429 Sobre la buena fe en materia civil destacan en el ámbito nacional las obras especializadas de FUEYO LANERI, Fernando, Instituciones de Derecho Civil o, Instituciones, Editorial Jurídica de Chile, Santiago, 1990, pp. 139-237; PEÑAILILLO Daniel, "La apreciación de la buena fe" en Revista de Derecho Universidad Católica de Concepción, vol. 2, №1, 1993, pp. 69-78; SAAVEDRA, Francisco, "El principio general de la buena fe" en Instituciones modernas de derecho civil, Ob. Cit., pp. 357-373; LÓPEZ SANTA MARÍA, Jorge, Los contratos, Parte General... Ob. Cit., pp. 389-407; GUZMÁN BRITO, Alejandro "La buena fe en el código civil chileno..." Ob. Cit., pp. 11-23; JoHOW SANTORO, Christian, "La interpretación del contrato y la buena fe" en Estudios de Derecho Civil-Código y dogmática en el Sesquicentenario de la promulgación del Código Civil, Lexis Nexis, Santiago, 2005, pp. 213-233; WeRner Carolina y NeHME Nicole, "El rol de los conceptos de orden público, buenas costumbres y buena fe en la contratación entre partes desiguales" en Sesquicentenario del código Civil de Andrés Bello, (Dir.) María Dora Martinic y Mauricio Tapia, Lexis Nexis, Santiago, 2005, pp. 647-662; CORRAL TALCIANI, Hernán, "“'La aplicación jurisprudencial de la buena fe objetiva en el ordenamiento civil chileno," en Revista de Derecho Privado, № 12- 13, Madrid, 2007, p. 143-177; SEPÚlVEdA LoRrouCAU, Marco, "Los grandes principios que inspiran al Código civil chileno" en Estudios de Derecho civil, grafica Kolbe, Santiago, 2007, pp. 111-123; CarvajaL, Patricio, "Artículo 706 del código Civil Chileno: crítica como pretendido núcleo textual del principio de la buena fe" en Estudios de Derecho Civil IV (Dir.) Carlos Pizarro Wilson, Legal Publishing, Santiago, 2009, pp. 31-45; SEgURA RIVEIRO, Francisco, "La buena fe, un aspecto de tensión entre los sistemas jurídicos" en Estudios de Derecho Civil V, Legal Publishing, Santiago, 2010, pp. 499-510; BOETSCH GILlet, Cristian, La buena fe contractual, Editorial Jurídica de Chile, Santiago, 2011.

${ }^{430}$ Véase, VV. AA.. Primer Proyecto de Código Civil de Chile, Santiago, Editorial Jurídica de Chile, 1978, p. 182.
} 
conventions] doivent étre exécutées de bonne fol". Por su parte, el artículo 1.135 señala: "Les conventions obligent non seulement à ce qui y est exprimé, mais encore à toutes les suites que l'équité, l'usage ou la loi donnent à l'obligation d'aprés sa nature".

Andrés Bello, ${ }^{431}$ redactor del Código resumió y unificó hábilmente las dos normas francesa, para dar vida al artículo 1546, eliminando de la disposición a la equidad. Esta omisión, puede explicarse porque el concepto de equidad resultaba ser repetitivo para Bello, ya que, si los contratos deben ejecutarse de buena fe no podía conceptualmente agregarse que, como consecuencia, obligaban a lo que imponía la equidad. ${ }^{432}$

Bello conocía perfectamente la esencial conexión de la bona fides con el círculo de obligaciones más amplio que el expresado en el contrato a que sus partes se ven sometidas. Escribió, en efecto, en su obra Instituciones de Derecho romano de 1843 lo que sigue: "Últimamente se dividen [SC. los contratos] en unilaterales, en que se obliga una sola de las partes y bilaterales, en que se obligan ambas. Aquellos se llaman también stricti iuris, y estos bonae fidei: en los primeros nada más se puede pedir que lo que expresamente se ha pactado, y en los segundos se debe además todo aquello que exige la equidad". 433

\footnotetext{
${ }^{431}$ Véase sobre Bello y su obra en: GuZMÁn BRITo, Alejandro, Andrés Bello Codificador, Ediciones Universidad de Chile, Santiago, 1982.

${ }^{432}$ DöRR Zegers, Juan Carlos "Notas acerca de la Teoría de la Imprevisión" en Revista Chilena de Derecho, vil. 12, № 2, 1985, p. 268.

${ }^{433}$ BeLLo LóPEZ, Andrés, Instituciones de derecho romano, lib. III, título. 14, en Obras completas de Andrés Bello, Caracas, La Casa de Bello, 1959, reimp. 1981, XVII, p. 134.
} 
En un análisis comparativo de ambas normas, Guzmán Brito, ${ }^{434}$ observa dos significativas diferencias.

La primera de ellas, el Code separa la ejecución de buena fe de las convenciones por un lado (artículo 1.134 inciso $3^{\circ}$ ), y el círculo de obligaciones que ellas imponen más allá de lo expresado por sus partes, por otro (articulo 1.135). Esto último no aparece como una consecuencia de la buena fe. El Código chileno, en cambio, considera que el círculo de obligaciones de un contrato, mayor al de las manifestadas en él, es una consecuencia -por consiguiente- de la buena fe con que deben ejecutarse.

La segunda diferencia, es que el Code hace obligatorias las "suites que l'équifé, l'usage ou la loi donnent à i'obligation d'aprés sa nature". Ese cuerpo legal, pues, supone que la equidad, el uso o la ley atribuyen a cada obligación, según su naturaleza, ciertas "suites", que el artículo 1.135 hace también obligatorias para las partes de una convención. En cambio, el Código chileno supone que hay "cosas" que emanan de la naturaleza de la obligación (independientemente de la equidad, el uso o la ley) y que hay "cosas" que según la ley o la costumbre pertenecen a la obligación, "cosas" ambas que el artículo 1.546 hace vinculantes merced a la buena fe.

En el Código francés, por lo tanto, la "naturaleza de la obligación" cumple un papel secundario, de referencia y medida para las "suites" que la equidad, el uso o la ley dan a cada obligación. En el código chileno, la "naturaleza de la obligación" es directamente una fuente de "cosas" que pertenecen a la obligación, en el mismo nivel

${ }^{434}$ GuZMÁn BRITO, La buena fe en el Código ...” Ob. Cit., pp. 11-12. 
que la ley y la costumbre, que también son fuentes de "cosas" que pertenecen a ella.

Por último, concluye el autor, que se observar que el Code menciona a la equidad como atribuyente de "suites" a la obligación, que está ausente en el Código chileno como fuente de "cosas" de esta, aunque es claro que ella se ve reemplazada por la "naturaleza de la obligación". Por el contrario, ambas disposiciones concuerdan en que las partes de una convención o de un contrato no solo se vinculan u obligan a lo que en ellos se expresa, sino también a algo más, a ciertas "suites" o a ciertas "cosas" (aunque no se expresen).

Cuando el Código señala que los contratos deben ejecutarse de buena fe y obligan no solo a lo que en ellos se expresa, sino a todas cosas que emanan precisamente de la naturaleza de la obligación, esta afirmando categóricamente el principio de que todos los contratos son de bona fides, y no de derecho estricto, al respecto señala Fueyo: "en el Derecho moderno ya no hay contratos de derecho estricto, por disposición expresa de la ley."

Esta consecuencia que el codificador extrajo, se refieren específicamente a la extensión de las obligaciones contractuales más allá de los términos explícitos pactados. ${ }^{436} \mathrm{~A}$ primera vista, la consagración legal del principio de la buena fe contractual, aparece restringida en sus alcances.

\footnotetext{
${ }^{435}$ FUEYO LANERI, Fernando, Cumplimiento e incumplimiento de las obligaciones, Editorial Jurídica de Chile, Santiago, 1990, p. 178.

${ }^{436}$ CORRAL TALCIANI, Hernán, "La aplicación jurisprudencial de la buena fe objetiva en el ordenamiento civil chileno," ... Ob. Cit., p. 144.
} 
No obstante, la doctrina chilena en sintonía con los desarrollos de la doctrina extranjera, ha expandido la orbita de influencia de la buena fe contractual hasta llegar a calificarla de principio general de Derecho. ${ }^{437}$

iii.- Otros Códigos Europeos

La influencia del Código civil francés se deja sentir muy directamente en el Código civil italiano de 1942. Su artículo 1.375 reproduce el artículo 1.134 del Code y el artículo 1.124 del Codice civile de 1865.

Dicho artículo, referido a la ejecución de buena fe declara: "Il contratto deve essere eseguito secondo buona fede". Igualmente, el artículo 1.374 recoge los postulados del 1.135 francés en cuanto preceptúa que: "Il contratto obbliga le parti non solo a quanto è nel medesimo espresso, ma anche a tutte le conseguenze che ne derivano secondo la legge, o, in mancanza, secondo gli usi e l'equità".

La diferencia entre el Código civil italiano y el francés estriba como indica García Amigo- "en que el primero explica la

\footnotetext{
${ }^{437}$ Así, por ejemplo, FUeYo LANERI, Fernando, Instituciones de Derecho Civil Moderno... Ob. Cit., pp. 153-162; LóPEZ SANTA MARÍA, Jorge Los contratos. Parte general... Ob. Cit., pp. 391-392; SaAvedRa Galleguillos, Francisco Ob. Cit., pp. 357-373. GuZMÁn BRITO. Ob. Cit., pp. 21-23, ha defendido la unidad esencial de la buena fe, tanto objetiva como subjetiva, en tanto ambas dependen de un paradigma de valoración de la conducta del agente. Recientemente, se ha postulado la recepción de la categoría de las expectativas razonables para defender al contratante débil sobre la base de la extensión de la regla de la buena fe: PINOCHET OLAVE, Ruperto, "La protección del contratante débil: doctrina de las expectativas razonables", en Gaceta Jurídica N. ${ }^{\circ} 297,2005$, pp. 27-34.
} 
jerarquización de las fuentes de integración: autonomía de la voluntad, ley, usos y equidad". Pero, aunque el Código francés no lo hace expresamente, la jerarquía es similar. ${ }^{438}$

En lo particular, el artículo 1.175 del actual Código italiano representa una importante innovación, pues señala que: "Il debitore e il creditore devono comportarsi secondo le regole della correttezza", esto es, dentro del marco general de las obligaciones, se impone a las partes un comportamiento según las reglas de la corrección, lo que supone cumplir diligentemente la prestación, sin dañar a la otra parte en el curso de la ejecución de la relación obligatoria.

Para la doctrina italiana, ${ }^{439}$ el precepto viene a regular el deber de advertencia, aviso, información, solidaridad y protección hacia la persona y bienes de la contraparte, en relación con las diferentes circunstancias que pueden concurrir a lo largo del contrato y cuya vulneración pueden dar lugar a incurrir en responsabilidad contractual.

Concretamente, la corrección de la que habla el artículo en cuestión conecta con la buena fe del deudor, implicando para éste la ejecución de todas aquellas prestaciones instrumentales o accesorias y deberes en interés del acreedor y, para éste, exige una actitud de cooperación entre personas correctas para facilitar al deudor el cumplimiento de la obligación y evitarle inútiles perjuicios. De forma

\footnotetext{
${ }^{438}$ García Amigo, Manuel, "Consideraciones a la buena fe ....", Ob. Cit., p. 613.

${ }^{439}$ BIGLIAZZI GeRI, Lina, "Buona fede"... Ob. Cit., pp. 154 y ss.; BIANCA, Cesare Massimo, "La nozione di buona fede quale regola di comportamento contrattuale", Rivista Diritto Civile, I, 1993, pp. 205 y ss.; c, Francesco Donato, "Note in tema di buona fede ed equità", Rivista Diritto Civile I, 2001 pp. 537 y ss.; VECCHI, Paolo María, "Buona fede e relazioni successive all'esecuzione del rapporto obligatorio", en AA. VV., Il ruolo della buona fede oggettiva, vol. IV, Padua, 2003, pp. 370 y ss.; D'ANGELO, A., "Buona fede", en Tratatto di diritto privato (Dir. M. Bessone), vol. 13.4.2, Torino, 2004, pp. 89 y ss.
} 
que la salvaguardia de los intereses de la contraparte se ha de considerar comprendida en el contenido propio de la obligación.

En Alemania, la falta de una norma general que permitiera la creación normativa por parte del juez, sumado a las vicisitudes que traería el siglo XX, llevaría a la doctrina y jurisprudencia a recurrir a la buena fe objetiva como un instrumento de flexibilidad normativa a fin de adaptar el Derecho Civil a las nuevas exigencias económicosociales. ${ }^{440}$

El BGB, siguiendo la tendencia de los códigos modernos, consagró en el parágrafo § 242 la obligación del deudor de efectuar la prestación como exige la buena fe en atención a los usos del tráfico. 441

Los jueces alemanes dieron desde el comienzo una interpretación amplia y creativa al $\S 242$, introduciendo nuevas soluciones equitativas mediante dicha disposición. Así, ella aparecía súbitamente como un instrumento que velaba por la justicia en las relaciones jurídicas, incluso, a pesar del texto legal, constituyendo el fundamento textual para el otorgamiento de soluciones equitativas.

Este desarrollo estuvo respaldado por el aporte filosófico previo de Stammler, que buscaba escapar de las consecuencias adversas de

\footnotetext{
440 SCHMIDT, Jürgen, "§ 242" en J. Von Staudingers Kommentar zum Bürgerlinchen Gesetzbuch mit Einführungsgesetz und Nebegesetzen. Zweites Buch Recht der Schuldverhältnisse. Dreizehnte Bearbeiteung, Berlín, 1995, № 51 y ss; también en ZIMMERMANN, Reinhard \& WHITTAKER Simon et al., Good Faith in European Contract Law. Cambridge: Cambridge University Press., 2000, p. 18-32

${ }^{441} \S$ 242: "Der Schuldner ist verpflichtet, die Leistung so zu bewirken, wie Treu und Glauben mit Rücksicht auf die Verkehrssitte es erfordern." ("El deudor esta obligado a cumplir la prestación según las exigencias de la buena fe conforme a los usos del tráfico.")
} 
la excesiva limitación que suponía la normativa positiva de los nuevos códigos mediante el recurso a principios generales, así como de la Escuela del Derecho Libre, la cual realzaría la importancia de las cláusulas generales en la creación jurisprudencial, y en forma muy especial la buena fe. ${ }^{442}$

En 1954 el célebre romanista alemán Franz Wieacker, criticando la forma caótica en la cual la jurisprudencia alemana aplicaba esta norma, realizó una esquematización de la buena fe. Para este autor, la buena fe tiene en si una triple función en el ordenamiento: Primero, el juez actúa en cumplimiento estricto del ordenamiento jurídico escrito y en virtud de su officium iudicis, se limita a concretar el proyecto previamente establecido y planificado en la regulación legal.

En segundo término, el juez actúa con mayor libertad y praeter legem, cuando exige a las partes que en ejercicio de sus derechos se comporten de manera justa. Por último en tercer término, la aplicación del $\S 242$ se realiza contra legem, mediante la ruptura que la jurisprudencia acomete hacia un nuevo Derecho judicial que va más allá, tanto de la realización de un proyecto legislativo como de la salva guardia del Derecho y la justicia en el comportamiento concreto de la partes. ${ }^{443}$

Por consiguiente, en el derecho civil alemán la existencia de cláusulas generales como la de buena fe (§ 242) y las buenas

\footnotetext{
${ }^{442}$ WINKEL, Laurens "Some historical remarks on the use of open norms in Dutch private law: good faith in contract, social decency in tort", in Wacław Uruszczak et al. (eds.), Leges sapere, Studia i prace dedykowane prof. J. Sondlowi (Studies for Janusz Sondel), Cracovia, 2008, pp. 681-682.

${ }^{443}$ WIEACKER, Ob. Cit., pp. $49-86$
} 
costumbres (§138; § 826) del BGB, hicieron innecesario el desarrollo de una doctrina general de los Principios generales del Derecho y orillaron la cuestión a un aspecto meramente teórico, porque con ellas había suficientes válvulas de escape para la necesaria flexibilización del Derecho.

En definitiva, el $\S 242$ es concebido como base de un principio general independiente de la formulación legal, a tenor del cual los sujetos de una relación jurídica deben observar el mandato de tener en consideración los intereses legítimos de la otra parte. De estos planteamientos han derivado las instituciones del nuevo derecho alemán de obligaciones, muy en especial los $\S 313$ y $\S 314$, que recogen los supuestos de cambio de las circunstancias por causa sobrevenida, permitiendo la resolución del contrato por excesiva onerosidad, así como la extinción de la obligación en los contratos de largo tiempo cuando concurre una justa causa.

iv.- Common Law

En Inglaterra, ha habido una considerable resistencia e incluso, hostilidad a su recepción, y la tardía introducción de este concepto en el Derecho británico se dio solo a mediados de la década de 1990 al implementar la directiva 93/13/CEE. 
Al respecto Zimmermann señala al respecto: "ello no significa que el derecho contractual inglés no sea inherente y equitable." ${ }^{444} \mathrm{Si}$ analizamos la tradición histórica inglesa nos encontramos manifestaciones a través de la lex mercatoria, la aequitas canónica y la jurisdicción del Lord Chancellor, que han abierto caminos más flexibles por los que ha penetrado la bona fides y han evitado que la Common Law se petrifique en la tradición y el formalismo riguroso. Asimismo, los tribunales han ido, poco a poco, resolviendo en equidad y también han ido imponiendo un estricto Código moral en las relaciones jurídicas. ${ }^{445}$

Por otra parte, el concepto adquirió un papel protagónico en Estados Unidos luego de la amplia consagración que tuvo en el Uniform Commercial Code, §§ 1-203 y 1-304, (UCC) a mediados de siglo, curiosamente por medio del influjo de la doctrina alemana en el pensamiento de Karl Llewellyn, uno de los principales redactores de dicho Código.

La buena fe experimentó otro nuevo empujón, especialmente a partir de la década de 1980, al ser incluida en el $\S 205$ del Restatement (2nd) of Contracts, y eventualmente se expandiría a otros países del Common Law. ${ }^{446}$

\footnotetext{
${ }^{444}$ ZIMMERMANN, Reinhard, "Rasgos fundamentales de un Derecho contractual europeo", en Estudios de Derecho Privado, Madrid, 2000, p. 156.

${ }^{445}$ Véase por todos, GOODE, Roy, "The Concept of Good Faith in english Law", en Centro di studi e ricerche di Diritto Comparato e straniero. Saggi, conferenze e seminari, 2, Roma, 1991, pp. 1-9.

${ }^{446}$ SUMMERS, Robert, "The conceptualization of good faith in American contract law: a general account" in Good faith in European Contract Law, Reinhard Zimmermann \& Simon Whittaker (Dir.) Cambridge, University Press, 2000, pp.118-141.
} 
Observamos que siguiendo la influencia del Civil Law, las partes se someten a los mandatos de la buena fe en la ejecución de los contratos que celebran. Asimismo, la jurisprudencia inglesa asume, cada vez más, directivas que incorporan el principio de la buena fe a sectores de su ordenamiento, como el referido a los contratos celebrados con los consumidores. ${ }^{447}$

Con todo, debe consignarse que el papel que la buena fe cumple en estos ordenamientos es menor que en los sistemas de Derecho Continental.

c.- La buena fe en el Derecho privado internacional y Soft Law

La importancia de la buena fe no se ha limitado a los ordenamientos nacionales, $\mathrm{y}$ ha adquirido protagonismo en los esfuerzos de unificación normativa en el ámbito internacional.

Un ejemplo paradigmático lo constituye la directiva 93/13/CEE art. 3, que consagró en el entorno europeo a la buena fe como uno de los parámetros para determinar cuándo se está frente a una cláusula abusiva en materia de protección al consumidor.

Así también se consagro de manera amplia en la Convención de las Naciones de Unidas sobre los contratos de compraventa internacional de mercaderías de 1980, (CISG), artículo 7 (1): "En la interpretación de la presente Convención, se tendrán en cuenta su

${ }^{447}$ ZIMMERMANN, "Rasgos fundamentales..." Ob. Cit., p. 157. 
carácter internacional y la necesidad de promover la uniformidad en su aplicación y la observancia de la buena fe en el comercio internacional. ${ }^{\$ 448}$

La idea de que cada parte contratante tiene la obligación de actuar conforme a las exigencias de la buena fe ha sido expresamente incorporada a los "Principios de Derecho Contractual Europeo" (PECL) art. 1:201.1: "Buena fe contractual. (1) Las partes deben actuar conforme a la buena fe contractual. (2) Las partes no pueden excluir o limitar este deber. ${ }^{449}$ Sobre este particular, Hesselink ha llegado a afirmar que los Principios de Derecho Contractual Europeo "representan el triunfo internacional de la noción de buena fe contractual." ${ }^{340}$

Por su parte, los principios UNIDROIT, consagran en el artículo 1.7: "(Buena fe contractual) (1) Las partes deben actuar conforme a la buena fe y la lealtad en el comercio internacional. (2) Las partes no pueden excluir o limitar este deber." ${ }^{\text {,451 }}$

En este mismo orden de ideas, el Draft Common Frame of Reference (DCFR), se hace referencia expresa a la buena fe y su

\footnotetext{
${ }^{448}$ Art. 7 (1): In the interpretation of this Convention, regard is to be had to its international character and to the need to promote uniformity in its application and the observance of good faith in international trade. (CISG) Convención de las Naciones Unidas sobre los contratos de compraventa internacional de mercaderías, Viena el 11 de abril de 1980.

${ }^{449}$ PECL art. 1:201: Good Faith and Fair Dealing. (1) Each party must act in accordance with good faith and fair dealing. (2) The parties may not exclude or limit this duty.

${ }^{450}$ HESSELINK, M. W., "The principles of European contract Law: some choices made by the Lando Commission", en Principles of European Contract Law, Deventer, 2001, p. 54.

${ }^{451}$ UNIDROIT, Art. 1.7: (Good faith and fair dealing) (1) Each party must act in accordance with good faith and fair dealing in international trade. (2) The parties may not exclude or limit this duty.
} 
relación con las obligaciones implícitas que vinculan a las partes en la relación obligacional. ${ }^{452}$

Así, en el señalan en l-1:103: "Buena fe y trato justo. (1) 'buena fe y trato justo' La expresión se refiere a una norma de conducta que se caracteriza por la honestidad, la transparencia y la consideración de los intereses de la otra parte en la transacción o la relación en cuestión. (2) Es, en particular, contraria a la buena fe y trato justo para un partido de actuar en consonancia con las declaraciones anteriores de ese partido o conducta cuando la otra parte ha confiado razonablemente en ellas en detrimento de la otra parte." ${ }^{453}$

Igualmente, en el Anteproyecto de Código Europeo de contratos, ${ }^{454}$ promovido por Gandolfi, se hace referencia a la buena fe, imponiendo reglas de conducta en algunos de sus artículos. Así, el artículo 1.2 dispone que "el acuerdo puede establecerse también mediante actos concluyentes, positivos $u$ omisivos, siempre que sea conforme a una voluntad precedentemente manifestada, a los usos o a la buena fe".

\footnotetext{
${ }^{452}$ Art. II-9:101 del DCFR: "Contenido del contrato. (1) El contenido del contrato se deriva de los acuerdos expresos y tácitos de las partes, de las reglas legales y de las prácticas establecidas por las partes o por los usos. (2) Cuando sea necesario regular una materia que las partes no han anticipado o regulado, el tribunal puede deducir una cláusula adicional, en particular, de: (c) las exigencias de la buena fe y la lealtad en los tratos".

${ }^{453}$ (DCFR) I-1:103: Good faith and fair dealing. (1) The expression 'good faith and fair dealing' refers to a standard of conduct characterized by honesty, openness and consideration for the interests of the other party to the transaction or relationship in question. (2) It is, in particular, contrary to good faith and fair dealing for a party to act inconsistently with that party's prior statements or conduct when the other party has reasonably relied on them to that other party's detriment..

${ }^{454}$ GaRcía CANTERO, Gabriel, "El anteproyecto de Código Europeo de contratos- Proyecto Gandolfi o del Grupo de Pavía", en Derecho Privado europeo (Dir. S. Cámara Lapuente), 2003, pp. 205 y ss.
} 
El art. 7, referido al deber de información pre-contractual, hace responsable a la parte que, en contra de los principios de la buena fe, oculta información a la otra parte; dado que el fundamento de tal obligación de información radica en la "buena fe objetiva" que debe presidir la actuación de las partes, no sólo en la fase propiamente contractual, sino también en la pre-contractual.

En cuanto a la realidad latinoamericana, y sus intentos de unificación normativa en materia de contratos, resalta el "Proyecto de principios latinoamericanos de Derecho de los contratos", en dicho proyecto inédito la buena fe contractual ocupa un papel protagónico, destacando entre los principios generales en materia de contratación. Así, establece: "Buena fe. (1) Las partes deben comportarse conforme a las exigencias de la buena fe conforme a los usos del tráfico. (2) Las limitaciones convencionales a este deber no producirán efecto alguno."

El proyecto no se conforma con esta referencia genérica, y establece adicionalmente numerosas remisiones a la buena fe objetiva en las más diversas materias: responsabilidad precontractual, revocación de la oferta, caducidad de la oferta, la oportunidad de la aceptación, error, dolo, excesiva desproporción y los remedios por incumplimiento.

A modo de conclusión, podemos señalar que en general, en todos estos cuerpos normativos, la buena fe aparece no sólo como una disposición general sino que se aplica como parámetro normativo para la resolución de hipótesis particulares. 
d.- En síntesis

El principio de la buena fe en los sistemas romano-germánicos es un mecanismo mediante el cual se aspira a que el desenvolvimiento de las relaciones jurídicas se produzca de acuerdo a unas reglas que la conciencia social considera justas, permitiendo además adaptar el derecho a las transformaciones sociales, lo que evita las disfunciones provocadas por el formalismo legalista derivado de la rigidez abstracta de las normas jurídicas.

En términos generales, el principio de la buena fe es un buen instrumento supletorio para flexibilizar las disposiciones legales, con consecuencias efectivas en el derecho contractual. En los diferentes países de la Unión Europea, especialmente en algunos como España y Alemania, la buena fe se ha transformado en un instrumento extremadamente útil para el desarrollo de un Derecho dinámico, como es el Derecho contractual.

En la experiencia jurídica española, la formulación explícita de la buena fe y su incorporación al Código Civil, junto con su positivación específica en otros ámbitos normativos, ha promovido su vigencia y efectividad. Estos precedentes jurídicos pueden ser de gran utilidad para intentar encontrar las bases de un futuro derecho contractual europeo y, si es factible, para la elaboración de una futura Codificación europea. 
Así, el concepto de buena fe como máxima de comportamiento exigible a las partes contratantes, perfectamente identificable en los PECL, es, además, compatible con la normativa unitaria de la compraventa y con los Principios UNIDROIT. Lo que permite vislumbrar algunos contornos concretos de un Derecho contractual transnacional.

\section{2.- LA INCLUSIÓN DEL DEBER DE PROTECCIÓN MEDIANTE LA BUENA FE}

Como hemos demostrado en el curso de esta investigación, en la relación obligatoria junto a interés fundamental del acreedor a la realización de la prestación, convive otro interés próximo, a que del vínculo obligacional no deriven daños para la persona o el patrimonio de cualquiera de las partes de la relación obligatoria.

En este sentido aparecen en la relación los deberes de protección, para hacer frente a los peligros y riesgos del especial contacto social que se deriva de la orbita contractual.

Estos deberes, acceden a la relación obligacional, para preservar la indemnidad de la persona o el patrimonio de los contratantes, sin que estos últimos hallan hecho mención alguna a esta manifestación, por cuanto, en el contrato se encuentran todas las consecuencias jurídicas que por su naturaleza, se entienden incorporados en él en virtud del principio general de la buena fe. Lo anterior, es un fiel reflejo del remanente romano, y de su inclusión 
normativa forjada por codificación, como hemos analizado anteriormente.

Esta cláusula general de la buena fe, en función de parámetros de licitud del comportamiento de las partes, permite pensar en los deberes de protección no como en una categoría doctrinal o jurisprudencial sujeta al parecer de las opiniones, sino como en una verdadera categoría normativa en todos lo efectos.

Para abordar dichos efectos, será necesario entender como se asimila el contenido de la buena fe contractual a las partes en la relación obligatoria y como ejerce la buena fe su influencia dentro del contrato, es decir, cuales son los mecanismos jurídicos por medio de los cuales la buena fe opera concretamente en la orbita contractual apropósito de nuestro especial objeto de estudio.

a.- El contenido de la buena fe contractual

Como sabemos, la imposibilidad de formalizar un concepto exacto de la buena fe, ha llevado a la doctrina y jurisprudencia a la necesidad de delimitar a lo menos un contenido general dentro del contrato. Una fórmula aceptable es entender este consiste en que cada parte debe tomar en cuenta el legitimo interés de su contraparte. ${ }^{455}$

\footnotetext{
${ }^{455}$ ZIMMERMANN \& WHITTAKER, Ob. Cit., p. 31; GHESTIN, Jacques, "L'analyse économique de la clause générale", en General clauses and standards in European Contract Law. (Dir.) Stefan Grundmann y Denis Mazeaud, The Hague: Kluwer Law International, 2006, p. 169. Esta fórmula se consagra en recientes instrumentos de unificación europea, como los
} 
En el contenido de la buena fe contractual, se pueden identificar dos nociones generales. En primer lugar, suele abordarse la buena fe desde la perspectiva negativa, de la mala fe y, en este sentido, su función sería proscribir conductas deshonestas, oportunistas o abusivas. La buena fe establecería de esta forma, un límite, representando un deber negativo de abstenerse de incurrir en conductas perjudiciales en el ejercicio de un derecho, y su función resulta hasta cierto punto análoga a la exceptio doli.

En segundo lugar, existe una dimensión positiva que implica promover los intereses de la contraparte y cumplir con sus expectativas bajo un clima de colaboración y lealtad recíproca, abarcando un espectro mucho más amplio de conductas que el simple el deber de abstenerse de perjudicar a la contraparte.

Betti, efectúa una conocida distinción entre deberes negativos y positivos que emana de la buena fe. El negativo se halla esculpido en la máxima romana del «alterum non laedere» (...) y que lleva a exigir un comportamiento de respeto, de conservación de la esfera de interés ajeno. $Y$ por su parte el positivo, que impone no simplemente una conducta negativa de respeto, sino una activa colaboración con los demás, encaminada a promover su interés. El primero se identifica en el Código civil italiano en el artículo 1.175 (correttezza) que solo impone un deber negativo. El segundo, contenido en el artículo 1.375 que es un deber positivo por antonomasia (buona fede). ${ }^{456}$

PECL art. 1:201(D) ("due regard for the interests of the other part") y el DCFR art. I.-1:103 (1) ("consideration of the interests of the other part").

${ }^{55}$ BETTI, Teoría General de las.." Ob. Cit., pp. 71 y ss. 
La distinción entre deberes negativos y positivos que emanan de la buena fe es enunciada de forma menos drástica por algunos autores. En este sentido Jacques Ghestin plantea que en el juego entre la contraposición de intereses antagónicos de las partes y la exigencia de comportarse de buena fe se pueden distinguir diversos grados de intensidad de la misma, que van desde las exigencias mínimas de cumplir con lo acordado y abstenerse de conductas manifiestamente fraudulentas, dolosas y desleales hasta deberes más exigentes, como cumplir con ciertos deberes de información a fin de remediar asimetrías o satisfacer un cierto nivel de cooperación atendiendo a los intereses legítimos de la contraparte, lo que podría llevar incluso a exigir la postergación de intereses propios. ${ }^{457}$

El grado de intensidad dependerá del cúmulo de circunstancias del caso concreto como indica Ewan McKendrick ${ }^{458}$ que vislumbra un espectro de significados de la buena fe con dos extremos: un contenido mínimo lo representa la noción de honestidad, mientras que el otro extremo exige dar prioridad a los intereses de la contraparte por sobre los propios. Entre estos extremos, la pregunta vital es en qué medida se compatibiliza la prosecución del interés propio con el respeto a los intereses de la contraparte, y si la buena fe impone sólo un deber negativo de abstenerse de conductas deshonestas o si exige deberes positivos, ambas interrogantes parecen conducirse, respecto de lo que se determinará según las circunstancias del caso concreto.

\footnotetext{
457 GHESTIN, Ob. Cit., pp. 169-170.

458 MCKENDRICK, Ewan, "The meaning of 'Good Faith”, Liber amicorum Guido Alpa. in Basil Mareskinis et al. (Dir.), London: British Institute of international and comparative law, 2007, pp. 692-698.
} 
En este sentido, la buena fe -como hemos afirmado- responde a un principio ético-social, que alude a conceptos como el de lealtad, honradez, respecto, fidelidad y rectitud entre otros. Este principio adquiere en materia negocial, una de sus manifestaciones más fuertes, pues se nos presenta como modelo de conducta que las partes deben seguir durante toda la vida del contrato.

Los contratantes, desde el momento de iniciar tratativas de un negocio jurídico y durante toda su extensión, depositan su confianza en la contraparte, en el sentido de esperar que esta se comportará de manera fiel, cooperando para que la realización del contrato sea la más conveniente para ambos.

Así la buena fe, aparece como un criterio de reciprocidad que debe ser observado mutuamente por las partes en la orbita contractual. Jordano Fraga subraya al respecto: "Si la buena fe por una parte ensancha el ámbito de la responsabilidad contractual al servir de base a una serie de deberes accesorios del deudor a favor del acreedor, dirigidos ya sea, a la realización del cumplimiento, ya sea a la preservación del daño en intereses diversos de aquel de pretensión (deberes de protección), el carácter reciproco de este criterio de conducta se actúa, por una parte, con la existencia de deberes de protección a favor del deudor, y por otra, por tutela que la buena fe, como criterio que fija el limite de lo exigible, ofrece al interés específico del deudor en cuanto tal (pues la relación puede ser sinalagmática), es decir, liberación." ${ }^{459}$

459 JORDANO FRAGA, La responsabilidad...." Ob. Cit., p. 143, 
b.- Buena fe y la integración del contrato

Con el perfeccionamiento del contrato, las partes buscan satisfacer una determinada necesidad de tipo práctico y establecen las principales reglas de conductas que habrán de regir en el futuro.

Todo contrato, se celebra con el fin de producir efectos jurídicos determinados, que son a su vez intencionalmente queridos por las partes. Lo convenido por ellas será, en virtud del efecto vinculante del contrato, una "ley" para estas, esta especie de autorregulación, derivada de la autonomía de la voluntad o voluntad privada, determinará en principio el contenido que deben tener las reglas contractuales.

Sin embargo, la citada autorregulación contractual no puede tener la aptitud para contemplar todos los posibles aspectos de la futura relación jurídica. Ninguna capacidad de previsión -por estricta que esta fuere- podría contemplar la totalidad de eventos que se pueden presentar en la ejecución de una relación obligatoria, ni establecer de antemano, las soluciones a toda posible controversia. ${ }^{460}$

i.- Función

\footnotetext{
${ }^{460}$ ALPA, Guido, Appunti sulla buona fede integrativa nella prospettiva storica e del comercio internazionale, in I contratti, 2001, pp. 723-229 también en ALPA, Guido, BESSONE, Mario, "L'integrazione del contratto in generale", in I Contratti in generale, Torino, UTET, 1999, pp. 120-155;
} 
Para llenar esta especie de "laguna legal", en la relación contractual, será necesario recurrir a otra fuente diversa que la voluntad de las partes, en este sentido, se requerirá a una fuente heterónoma, ${ }^{461}$ como es el caso de la buena fe, con la cual se podrá integrar el contenido de la regulación que habrá de regir las relaciones de las partes. A través de este procedimiento se puede hallar el "contenido implícito" del contrato. ${ }^{462}$

En el proceso de integración del contrato, la autonomía de la voluntad se encontrará en "concurso" con otras fuentes de determinación del contenido del contrato, con las que, en algunas ocasiones, se podrá encontrar en posición subordinada, e, incluso, antagónica, lo que podría conducir a que la manifestación de voluntad sea depurada o corregida, para mostrarse, entonces sí, en la plenitud de su alcance y pormenores. ${ }^{463}$

Si la norma o el contrato nada previeron o no fueron claros sobre como proceder, la solución a este "vacío contractual" debe obtenerse a partir de la buena fe. Esta actúa adaptando o flexibilizando la elación obligatoria al caso en concreto ante situaciones no previstas, contratos incompletos, silencio, oscuridad de lo previsto o bien por el cambio de las circunstancias. ${ }^{464}$

\footnotetext{
${ }^{461}$ Se diferencia la autointegración de la heterointegración, queriendo con ello destacar que en la primera los elementos de integración surgen del mismo contrato. Mientras que en la segunda dichos elementos viene dados desde fuera del contrato, como es el caso de la buena fe. Véase, ALPA, Guido, BESSONE, Mario, 'L' integrazione del contratto in generale....",Ob. Cit., pp. 120-155; también en CABANILLAS SÁNCHEZ, Las cargas del acreedor..." Ob. Cit., pp.17 y ss.

462 SOLARTE, Ob. Cit., p 291.

${ }^{463}$ Bigliazzi Gerl, Lina Breccia, Umberto y Busnelli, Francesco, Diritto Civile, vol. 2, edizioni UTET, 1988, p. 643 y ss

${ }^{464}$ ORDOQUI, Ob. Cit., p. 218.
} 


\section{ii.- Proceso}

Como señala Lasarte, la finalidad de la integración es "incardinar el contrato en un ambiente normativo," ${ }^{465}$ reflejado en la propia ley, la costumbre, la equidad natural y la buena fe.

Toda integración se nutre de elementos externos al propio contrato, en ellos estriba su importancia, es decir, su ajuste con la realidad. Como sostiene Sacco, ${ }^{466}$ en la integración se produce la penetración deontológica de opiniones o valores socialmente más aceptables que entran dentro de las normas generales previstas para la integración del contrato, como es, precisamente la vigencia de la buena fe.

La integración del contrato encuentra su fundamento normativo inmediato en la clausula general de la buena fe contenida en la mayoría de los Códigos decimonónicos (Cc. Francés, 1.134-1.135, Cc. Español 1.258, Cc. Italiano 1374-1.375, BGB § 242, Cc. Chileno 1.546.) También encontramos esta remisión, en la legislación unificadora en materia de contratos, tales como los Principios UNIDROIT sobre contratos comerciales internacionales y los Principios del Derecho Contractual Europeo (PECL).

\footnotetext{
${ }^{465}$ LASARTE, Carlos, "Sobre la integración del contrato: la buena fe en la contratación", Revista de Derecho Privado, Madrid, 1980, pág. 50 y sigs.

${ }^{466}$ SAcco, Rodolfo, "L'integrazione" en Tratatto de Diritto Privato (Dir.) Pietro Rescigno, t. X, Torino, 1982, p. 472
} 
La clave para entender la referencia que hace el legislador esta cláusula, esta en la "naturaleza de la obligación o del contrato", que según el jurista Wieacker no debe pasar inadvertida, al sentido y significación del contrato pertenecen de manera especial los llamados o naturalis ratio o naturalia negotii de la tradición romana y del Derecho común. Que con frecuencia no son convenidos de forma expresa precisamente porque valen entre las partes como naturalia. Fundamentalmente es aquí donde las obligaciones accesorias derivadas de la naturaleza de las cosas encuentran su sitio, en particular las consecuencias necesarias de las obligaciones aceptadas de modo expreso. ${ }^{467}$

A mayor abundamiento, debemos recordar, que la cláusula $e x$ fide bona no sólo plasmaba el poder del juez para apreciar libremente los casos, sino que viene a fijar esta cláusula como un verdadero principio de integración de deberes contractuales, a fin de equilibrar las posiciones de los contratantes y de impedir lucros injustificados.

Aparece así, la bona fides como base reguladora de los negocios jurídicos no solemnes, enriqueciendo -respecto a lo acordado por las partes- el contenido de los contratos. ${ }^{468}$

En el Derecho común, también encontramos esta remisión, así se aprecia en Bartolo de Saxoferrato: “...in contractibus bonae fidei veniunt ea de quibus non est actum nec cogitatum..." ${ }^{469}$ Es decir, la bona fides se ve como un elemento de integración del contrato, puesto que

\footnotetext{
${ }^{467}$ WIEACKER, Ob. Cit., pp. 45-44.

${ }^{468}$ SalazAR ReVUelta, Ob. Cit., p. 124

${ }^{469}$ De SASsoferRato, Bartolo., Prima super Codice, Lugduni, 1533, f. 138 vb, n. 1 ad 1. Bonam fidem. C. 4,10,4.
} 
en los contratos de buena fe, en opinión de este jurista, se tienen en consideración aquellas cuestiones sobre las que no se haya acordado, ni pensado.

En el lenguaje jurídico moderno también se encuentra la remisión de la naturalia negotti claramente identificable, por cuanto, estos serían aquellos elementos de un contrato que, "no siendo esenciales en él, se entienden pertenecerle, sin necesidad de una cláusula especial", y dicha "pertenencia" se daría a través de la aplicación de la buena fe, en la cual estaría la regulación "natural" de cada contrato.

Otra óptica, en el mismo sentido, es entender que a través de los elementos de la naturaleza se incorporan al contrato "las prácticas usuales y los estándares propios de las negociaciones honestas seguidas en el tráfico jurídico", toda vez que las "cosas de la naturaleza" penetran en el contrato y se instalan en él por virtud de la buena fe.

Betti señala al respecto, la buena desde el punto de vista del deudor, lleva a imponer a quien debe la prestación a hacer todo cuanto sea necesario- se haya dicho o no- para asegurar a la otra parte el resultado útil de la misma. De este modo, la buena fe, en cuanto integradora de la obligación textualmente asumida con el contrato, impone al deudor el hacer no solo aquello que ha prometido sino todo aquello que es necesario para hacer llegar a la contraparte el pleno resultado útil de la prestación debida. ${ }^{470}$

${ }^{470}$ Betti, Ob. Cit., pp. 103-104. 
En síntesis, por la vía de la buena fe es posible integrar al contrato deberes nunca expresados por las partes, -como es el caso de los deberes de protección- en la medida en que estos, se derivaran de la confianza depositada en la conducta de la otra parte del contrato.

Esta buena fe integradora, produce un enriquecimiento del contenido contractual, ya que a través de ella se dota de un sentido más amplio a los deberes creados por el contrato que atenderán particularmente a la naturaleza del mismo y a su finalidad.

Así, los deberes de protección accederán a la relación obligatoria integrados por la buena fe, los cuales serán plenamente exigibles por ambas partes, por cuanto, ambas partes tienen la obligación de cooperar para lograr que se satisfaga el interés integro del contenido del contrato, esto es, tanto el interés propio de la prestación, como la indemnidad de las partes en la prosecución del mismo.

c.- Normatividad de la buena fe contractual

Hoy se asume con total naturalidad que en el contrato aparezcan obligaciones que las partes no han previsto expresamente. Estos deberes u obligaciones se presentarán como un "plus" de la relación obligatoria, ampliando su contenido, en otros casos operarán como corrección de la voluntad de las partes, y en otros actuarán como limite al ejercicio abusivo del derecho. 
No son imprevisto o una cobertura sobre las eventuales modificaciones del objeto de lo convenido, sino son algo que se impone con fuerza normativa autónoma y originaria en las relaciones contractuales, fijando con ello poder y deberes.

Aunque algunos entiende que la función integradora comprende también a la normativa o creadora, nosotros, separaremos para su estudio a esta última, ya que, si bien sus supuestos son comunes, en la práctica difieren en orden de sus aplicaciones y manifestaciones. En este sentido, de tales manifestaciones podremos deducir, -como veremos- otras funciones o subprincipios que servirán de base para la aplicación de los deberes de protección en la orbita contractual.

i.- Subfunción creadora o jurígena

La función jurígena de la buena fe, ha estado unidad a su evolución desde su inicio. Así la bona fides, entendía en su esencia la capacidad que tenia el juez para anexar a la formula otras consecuencias inherentes al contenido del contrato que no habían sido previamente expresadas por las partes.

Ya en Cicerón se destaca esta transcendental función, en un pasaje de su texto de officis, ${ }^{471}$ este recuerda como para pontífice

\footnotetext{
${ }^{471}$ CICERÓN, de officis, 3,17,70: "Ut inter bonos bene agir oportet et sine fraudatione! Sed, qui sint boni et quid sit bene agi magna quastio est, Q. quidem Scaevola, pontifex maximus, suman vim ese dicebat in ómnibus iis arbitriis, in quibus adderetur ex fide nona, fideique bonae nomen existimabat
} 
Quinto Mucio Escévola en los juicios en los cuales se agrega la clausula ex fide bona, se imprime una gran fuerza ("summa vis") por cuanto de la fides bona, emana un significado profundo y amplio, que se difunde extensamente en una virtual propensión a invadir las relaciones, razón por la que se aplica a todas las cosas que constituyen el fundamento de la vida social y en consecuencia en aquellos juicios, se requiere que un juez iluminado y sapiente determine las obligaciones que le correspondan a cada una de las partes.

La vis ingénita en estos juicios poseía un sentido de fuerza que genera significados, que modela conductas, que permite concretar la indeterminación del valor ínsito en los conceptos asumidos en la fórmula, traduciéndolos en normas de conductas y normas preceptivas, más allá de lo querido por las partes.

En ese orden de ideas, bona fides negotiae, obliga no solo a lo fijado en la convención y a los cuidados generales usuales entre personas honorables, sino a todas aquellas prestaciones accesorias que la circunstancias que rodean el negocio en cada momento vayan poniendo de manifiesto, con independencia de que hayan o no sido pactadas expresamente, como quiera que la fuerza de la buena fe,

\footnotetext{
manare latissime, idque versari in tutelis, societatibus, fidiciis, mandatis, rebus emptis, venditis, conuctis, lovatis, quibus vitae societas contineretur; in iis magni ese iudicis statuere, praesertim cum in plerisque essent iudicia contraria, quid quemque cuique praestare oporteret"(Conviene obrar bien y sin engaños entre gente bien. Pero la gran cuestión es determinar quién es la gente de bien y qué es obrar bien. Quinto Escévola, pontífice máximo, decía que en los juicios en los cuales se agrega la cláusula ex fide bona esta insta una gran fuerza, por cuanto del binomio fides bona promana un significado profundo y amplio que se vierte en las tutelas, en las sociedades, en la fiducia, en los mandatos, en las compras, en las ventas, en las conducciones, en las locaciones, cosas sobre las que se funda la vida social. En consecuencia, en aquellos juicios es tarea de un juez sapiente establecer las verdaderas obligaciones de cada una de las partes, sobre todo porque en la mayor parte de los casos hay acciones directas y contrarias).
} 
como principio normativo, integra el contenido del contrato, formándolo permanentemente a través del establecimiento de reglas concretas mediante las que se otorga la exacta dimensión al contenido de las obligaciones de las partes a la luz de la buena fe.

En este sentido, la buena fe no solo opera supliendo "lagunas", o iluminando la oscuridad de las expresiones de los contratantes, sino que también crear derechos y obligaciones ampliando el contenido de la relación contractual, pues, la aplicación de la cláusula general de la buena fe, tiene una potencialidad jurígena, es decir, de crear normas dispositivas y exigibles, en la relación contractual.

De este modo la aplicación de la cláusula general de la buena fe, genera dentro de la relación obligatoria ciertos deberes especiales de conducta, que deberán ser cumplidos por la partes tal cual como sus pretensiones, por cuanto, estos deberes son plenamente exigibles." ${ }^{\prime 72}$

Dichos deberes encuentra su fuente normativa en la buena fe, y se agregan a la orbita contractual, por cuanto, en el ejercicio de sus derechos las partes deberán actuar con lealtad y fidelidad, respetando el interés legítimo de su contraparte.

Enneccerus, señala que cada una de las partes, en el desarrollo de sus relaciones contractuales, ha de tener en cuenta el interés, de la otra parte, y ajustar su conducta de manera de evitar un menoscabo

${ }^{472}$ LASARTE, Ob. Cit., p. 73 
para la otra, de lo contrario, viola este deber contractual creado por la buena fe. ${ }^{473}$

Bajo este contexto, en los deberes de protección la función jurígena de la buena fe, alcanza en su máxima expresión, toda vez, que incorpora a la relación obligatoria tales deberes como normas expresas y vinculantes para las partes, en el sentido de preservar la indemnidad de la persona o el patrimonio de los contratantes, frente a los peligros y riesgos del especial contacto social que se deriva de la orbita contractual.

\section{ii.- Subfunción correctora y modificadora}

La autonomía de privada o de la voluntad, encausada en los Códigos decimonónicos, confiere el poder a los particulares de autorregularse en sus relaciones reciprocas. Es decir, esta noción entiende como pilar fundamental la libertad del hombre para determinar el contenido de sus actos jurídicos. ${ }^{474}$

No obstante, el ordenamiento jurídico entiende que tal manifestación no puede concebirse en términos absolutos, por lo cual reconoce necesariamente limites, que en la generalidad de los casos, será la propia ley, la costumbre o los usos y el orden publico o social.

\footnotetext{
473 ENNECCERUS, Ob. Cit., p.18

${ }^{474}$ FERRI, Luigi, La autonomía privada, Comares, 2001.; DIEZ-PICAZO, Luis, "A vueltas con la autonomía privada en materia jurídica", en Diario la ley, No 7765, 2011; GRoNDONA Mauro, "Derecho contractual europeo, autonomía privada y poderes del juez sobre el contrato", en Revista de Derecho Privado, № 22, 2012, pp. 135-147.
} 
La cláusula general de la buena fe, también importa un claro limite a la autonomía privada. Señala De los Mozos, la voluntad no se produce aislada, en un vacío jurídico, sino dentro del ordenamiento, y lo mismo que las normas imperativas limitan esa voluntad privada, hay un limite lógico, natural de la voluntad que impone la norma dispositiva el uso y la buena fe. ${ }^{475}$

En ocasiones, la imperatividad de la buena fe como determinante de la conducta debida y como efecto del contrato más allá de la voluntad de las partes permite que esta opere como correctora del contrato. Para Frigerio, la buena fe cumple una función correctiva de la patología de la contratación, porque permite al juez aplicar no la conducta reglada expresamente por las partes sino la conducta normal. ${ }^{476}$

Ordoqui, reconoce que la aplicación de la buena fe corrige o enmienda las estipulaciones contractuales que nos se ajusten a ella. En este sentido el juez puede y debe, no solo integrar o insertar obligaciones o deberes secundarios no previstos por las partes, sino que puede abolir aquellas disposiciones expresas que se aparten de la clausula general de la buena fe corrigiéndolas. ${ }^{477}$

Según hemos revisado, la buena fe importa un patrón de conducta que impone la obligación de comportarse lealmente, en la relación obligatoria, esto significa, que ambas partes deben cooperar

\footnotetext{
${ }^{475}$ De Los Mozos, El principio de la buena fe...."Ob. Cit., p. 128.

${ }^{476}$ FRIGERIO, Enrique, "La buena fe en el derecho de obligaciones," Revista de la Asociación de Escribanos del Uruguay, t. 55, Montevideo, 1969, pp.5-8

${ }^{477}$ ORDOQUI, Ob. Cit., p. 229
} 
entre sí para lograr satisfacer el interés tanto de prestación principal como el de protección, es decir, deben procurar obtener el interés que se tuvo en vista al momento de contratar sin perjudicar o lesionar la persona o el patrimonio de su contraparte.

En este orden de ideas, los deberes de protección se vinculan a la relación obligacional corrigiendo y modificando la voluntad de la partes en la medida que estas se han alejado de la patrón de conducta debida que significa la cláusula general de la buena fe.

\section{IV- FUENTES MEDIATAS}

Sin perjuicio, de la suficiencia e idoneidad de la buena fe como fundamento normativo inmediato del deber de protección. Existen en el ordenamiento jurídico otros supuestos normativos indirectos que dan justificación a nuestro objeto de estudio. En este contexto, estos supuestos, constituyen fuentes mediatas, que se suman y apoyan a la buena fe en la justificación de la inclusión de los deberes de protección en la relación contractual, en algunos casos concretos y determinados.

\section{1.- ABUSO DEL DERECHO}

Toda norma jurídica se refiere a la actividad del hombre frente a los demás, es decir, implica una relación entre sujetos: el activo y el 
pasivo, o sea, el sujeto que tiene el deber para con alguien y el sujeto, en favor de quien se tiene el deber. La vida del ser humano en sociedad lleva aparejada luego, la concesión de derecho subjetivos, que le confieren un poder de actuación para alcanzar su realización dentro de dicha sociedad.

El reconocimiento de los derechos subjetivos en el ordenamiento jurídico, supone en contraposición un limite o afección del interés del otro, por cuanto, resulta lógico, que los que se relacionen con el titular del derecho subjetivo deban respetar el ejercicio que este lleve a cabo de las facultades que le otorga. De lo que se sigue que los terceros, frecuentemente experimenten alguna suerte de perjuicio cuando otro ejerza su derecho que legalmente le corresponde.

Ya hace algunos siglos la sensibilidad de algunos juristas ha favorecido una contemplación matizada de la facultad de ejercitar los derechos subjetivos, por cuanto, la consagración absoluta e incondicionada puede dar origen a la irrogación de perjuicios a otros sujetos como consecuencia de la actuación arbitraria de los titulares de aquellos.

Es por ello que la generalidad de la doctrina reconoce la necesidad de que el derecho positivo debe acoger esa represión mediante una fórmula que solucione satisfactoriamente el conflicto de intereses entre el agente que ejerce su derecho en forma abusiva y el tercero que queda afectado por ese ejercicio. ${ }^{478}$

478 CuAdRAdo Pérez, Carlos, La moderna configuración de la doctrina del abuso del derecho, Aranzadi, Madrid, 2014, p. 13. 
De esta necesidad de corrección indispensable para conciliar los derechos del individuo con los de la sociedad, deriva una consecuencia concreta, para la noción de los deberes de protección, por cuanto, su función en la relación obligacional, representa una frontera correctora para la actuación de la autonomía privada, es decir, la sola presencia del deber de protección en la orbita contractual, trae consigo la imposibilidad del ejercicio absoluto de los intereses de prestación, por cuanto, el contenido de este, -el no dañar o perjudicar la persona o patrimonio de su contraparte- constituye a su vez, un limite cierto al ejercicio de los derechos de las partes.

En palabras de Josserand; “¿Cómo podría no ser así, en una legislación en la que todos los contratos son de buena fe? Un contrato de esta naturaleza, no produce derechos estrictos, sino limitados, tanto en su realización como en su contenido."479

Dado esta evidencias, resulta conveniente preguntarse, si la doctrina del abuso del derecho puede ser también una justificación de nuestro objeto de estudio, es decir, dicho de otro modo, si la vulneración de los deberes de protección importa un eventual hipótesis de abuso del derecho.

a.- Evolución de la teoría

479 JosserAND, Louis, El espíritu de los derechos y su relatividad, trad., Eligio Sánchez y José María Cajica, Granada, Colmares, 2012, p. 98. 
El origen de la doctrina del abuso del derecho ha sido ciertamente polémico, las dudas que genera su origen, son arduas y están lejos de resolverse de manera satisfactoria. Quizás el único avance sobre el particular sea el acuerdo que existe en torno a que los fundamentos más remotos de nuestra institución no llegan hasta el Derecho romano, sino que a un momento posterior, el Derecho medieval, a través de la teoría de los actos de emulación. ${ }^{480}$

No obstante ello, no debe pensarse que la noción de abuso del derecho era totalmente desconocida para el mundo romano. ${ }^{481}$ Así, podemos encontrar notas generales en donde la teoría del abuso del derecho ha sido desarrollada. Un ejemplo de ello, es la máxima qui iure suo utitur beminem laedit, que encontramos en el pensamiento de Gayo $^{482}$ y Paulo. ${ }^{483}$

En este sentido, Cuadrado Pérez, ${ }^{484}$ subraya que en la Instituciones de Gayo, puede vislumbrarse su esencia, cuando, al hilo del maltrato a los esclavos, se aporta otra frase posteriormente elevada a la categoría de principio: male enim nostro iure uti non

\footnotetext{
${ }^{480}$ En el sentido técnico la emulación, comprende aquellos actos que lleva a cabo el dueño, dentro de la esfera de su derecho, pero que en nada lo benefician, persiguiendo al mismo tiempo el objetivo de ocasionar un perjuicio al propietario de un fundo vecino. Véase, RUTHERFORD, Romy, "La "aemulatio" y en el abuso del derecho" en Revista de Estudios Histórico-Jurídicos, XXXV, Valparaíso, 2013, p. 635.

${ }^{481}$ Más que la existencia de una teoría general del abuso del derecho, los prudentes juristas romanos abordaron y resolvieron, dentro del principio de la equidad, cuestiones muy concretas en las cuales percibieron ciertos matices de un uso anormal del derecho. Fernández Sessarego, Carlos, Abuso del derecho, Editorial Astrea, Buenos Aires, 2002, p 80.; ATIENZA, Manuel, y MANERO, Juan Ruiz. Ilícitos atípicos: sobre el abuso del derecho, el fraude a la ley y la desviación de poder, Editorial Trotta, Madrid, 2000, p. 33.

${ }^{482}$ D. 50, 17, 55 Gayo, Libro II de Testamentis ad Edictum urbicum; "Nullus videtur dolo facere, qui suo iure utitur,"

${ }^{483}$ D. 50. 17, 151: Paulo, Libro LXV. ad Edictum; "Nemo damnu, facit nisi qui id fecit, quod facere ius non habet" También, 50. 17.155 (1): "Non videtur vim facere, qui iure suo utitur et ordinaria actione experitur"

${ }^{484}$ CuAdRAdo PÉREZ, La moderna...” Ob. Cit., p. 20.
} 
debemus. ${ }^{485}$ En este texto se dispone que ni a los ciudadanos romanos ni a ningún otro pueblo que estuviera bajo el poder de Roma estaba permitido maltratar a los esclavos sin justa causa, ni con excesiva crueldad.

Otro desarrollo, importante lo constituyó las acciones relativas a la vecindad y propiedad inmobiliaria contenidas en las inmisiones, no es extraño que el tema se desarrolle a propósito de los inmuebles, pues la interferencia, la coexistencia y el conflicto de derechos importan ante todo la necesidad de una línea de demarcación, que se muestra con plenitud en las limitaciones derivadas de las relaciones de vecindad, dado que es precisamente en ellas en que primero se pueden plantear dudas respecto de hasta qué punto se opera válidamente en la esfera de lo que es propio, o, en que momento se invade el ámbito de un tercero. ${ }^{486}$ Bajo este contexto, en el Digesto existen numerosos ejemplos a saber; (D. 8, $1,9,{ }^{487}$ D. $9,2,39,{ }^{488} \mathrm{D}$. $39,3,1,11$, y $\left.12{ }^{489}\right)$

485 "No debemos hacer mal uso de nuestro derecho" (Inst. I, 53)

${ }^{486}$ GÓMEZ RoYo, Enrique, El régimen de las aguas en las relaciones de vecindad en Roma, Valencia, Tirant Lo Blanch, 1997, pp. 28 y ss.

${ }^{487}$ D. 8, 1, 9, Celso, Libro V: "Nam quaedam in sermone tacite excipiuntur, non enim pervillam ipsam, nec per medias vineas ire, agere sinendus est, quum id aeque com ide per alteram partem facere possit minore servientis fundí detriment" En este pasaje se sostiene que el ejercicio de paso concedido por fundo ajeno ha de llevarse a cabo causando el menor perjuicio posible a su dueño.

${ }^{488}$ D. 9, 2, 39, Pomponio, Libro XVII. ad Quintum Mucium: "Itaque qui pecus alienun in agro suo deprehenderi, non iure id includit, nec agere illud aliter debet, quam, ut diximus, quasi suum; sed vel abigere debet sine danno, vel admonere dominium, ut suum recipiat." En este pasaje, se afirma quien hubiere encontrado una res ajena en su campo, no adueñarse de ella sino que cuidarla y avisar a sus dueño, es decir, no obstante que el animal se encuentra en su dominio, no puede tratarla como bien suyo.

${ }^{489}$ D. 39, 3, 1, 11, Ulpiano Libro LIII. ad Edictum, "Prodesse enim sibi unusquisque, dum alii non nocet, non prohibetur." En materias de aguas pluviales, se dispone que todos tiene derechos a retener el agua en su fundo o derivar hacia él la sobrante del vecino, con tal de no hacer obra en el predio ajeno, pues no se prohíbe que cada uno favorezca siempre que con ello no perjudique a otro. D. 39, 3, 1, 12, "Et sane non debet habere, si non animo vicino nocendi, sed suum agrum meliorem faciendi in fecit." En este pasaje se señala que no cabe demandar al que cava en su propio fundo y trae hacía él un manantial del vecino, si no lo hizo con intensión de perjudicar al vecino, sino que lo hizo para mejorar su propio fundo. 
La aemulatio, si bien adquirió su sentido técnico en la baja edad media, ya se les adjudicaba un significado negativo en Cicerón, ${ }^{490} \mathrm{y}$ Tito Livio. ${ }^{491}$ Así las cosas, fue durante el medioevo que inspirados por el Derecho justinianeo y los principios cristianos, que los glosadores (Cino de Pistola, Baldo, Bartolo Sasoferrato entre otros) en los siglos XIII y XIV crearon la institución de los "actos de emulación," al tenor de la cual proscribían los actos que reportaran utilidad al propietario de inmueble donde se producían, pero que irrogaran algún menoscabo a los poseedores de los fundos vecinos. ${ }^{492}$

No obstante, dado el influjo cristiano en el análisis de las fuentes romanas, implico la exigencia en la emulación del "animus nocendi", es decir, la intención de dañar a otro, por parte de quien ejercita su derecho.

El ámbito de aplicación de la aemulatio, se extendió más allá de las relaciones de vecindad, aunque siguió circunscrito a la propiedad inmobiliaria, pues llegó a involucrar las construcciones y edificaciones que se pueda hacer en lo propio, de modo que por esta vía llegó a incidir directamente en el concepto de derecho de dominio. ${ }^{493}$

\footnotetext{
${ }^{490}$ Cicerón, Tusculanae Disputationes, 4, 8, 17; “Aemulatio autem dupliciter illa quidem dicitur, ut et in laude et in vitio nomen hoc sit; nam et imitatio virtutis aemuatio cicitur-sed ea nihil hoc loco utimur; est enim laudis-, et est aemulatio aegritudo, si eo quod concupierit alius potiatur, ipse careat" ${ }^{491}$ Livio, 26, 38, 9, "Hannibali atque eis qui aderant quo audacior res erat, minus similis ueri visa est: aemulationem profeto atque odium ese, et id crimen adferri quod, quia testem habere non posset, liberius fingenti esset"

${ }^{492}$ CUADRADO PÉREZ, La moderna..." Ob. Cit. p. 29.

${ }^{493}$ VALDIÑo ARCOS, Alejandro, La aemulatio en el Derecho romano: su examen en sede de relaciones de vecindad y de calumnia procesal, Ediciones del Instituto de Historia del Derecho Juan de Solórzano y Pereira, Santiago, 2002, p. 119.
} 
La teoría de los actos de emulación constituyen la primera sistematización científica de los limites en el ejercicio de los derechos subjetivos y, como consecuencia, una dulcificación del rigor de la máxima qui iure suo utitur neminem laedit. Representa, pues el precedente inmediato de la doctrina del abuso del derecho, que surgirá, precisamente, con el designio de superar sus incontables falencias. ${ }^{494}$

Será durante la época moderna, donde hallaremos la génesis más próxima de la teoría del abuso del derecho. Sin perjuicio de lo anterior, su comienzo no podía ser menos esperanzador, puesto que, con el influjo de la codificación como tributario de los ideales revolucionarios, se declara el absolutismo de los deberes subjetivos, por lo que, no es de extrañar que en código de Napoleón se consagrara la propiedad en términos absolutos.

No obstante, la doctrina y jurisprudencia volverían a retomar la prohibición de los actos de emulación basados en el artículo 1382, transformándolos ahora en una teoría robusta y fundamentada, aplicable todos los derechos subjetivos. ${ }^{495}$

La experiencia germana, fue más directa, por cuanto, ya en el código prusiano de 1794, existe un reconocimiento explícito a la prohibición de los actos emulativos, por la influencia de escuela iusnaturalista, que en la visión de Pufendorf, subordina el derecho privado y al individuo a la suprema razón del derecho público. ${ }^{496}$ En la pandectística, desde Glüsk a Windscheid, se acepto la teoría de la

\footnotetext{
494 CuAdrado PÉRez, La moderna...” Ob. Cit. p. 32.

495 RUTHERFORD, Ob. Cit., p. 646.

496 Rotond, Mario, L'abuso di diritto, Cedam, Padova, 1979, p. 111.
} 
prohibición de los actos emulativos, no obstante, la férrea oposición de Jhering, ${ }^{497}$ estas circunstancias explican que finalmente el BGB en su $\S 226$ regule específicamente la prohibición de los actos emulativos.

Como señalábamos recientemente, la teoría del abuso del derecho propiamente tal, tuvo su origen inmediato en los aciertos jurisprudenciales, que fueron una consecuencia refraccionaria al exacerbado liberalismo e individualismo del Derecho francés de finales del siglo XIX. De esta manera podemos destacar las sentencias de la Cour d'appel de Colmar, de 2 de mayo de 1855 conocida comúnmente como "arrêt de la fausse chenunée" y la sentencia de la Cour de Cassation, de 3 de agosto de 1915, recordada como "arrêt Clément Bayard."498

En estos fallos, colisionan de frente con la omnipotencia del derecho de propiedad, abandonando del absolutismo de los derechos subjetivos por una noción relativa, es decir, no se consideran los derechos un fin en sí mismo, sino como un medio. Tal y como

\footnotetext{
${ }^{497}$ RotONDI, Ob. Cit., p. 112 y ss

${ }^{498}$ Sentencia de la Cour d'appel de Colmar, de 2 de mayo de 1855, conocida comúnmente como "arrêt de la fausse chenunée" en este caso el propietario elevó una falsa chimenea en su finca con el propósito de despojar de luz y de vistas al vecino. El tribunal apreció atención de perjudicar, así como ausencia de interés serio y legitimo por parte de quien, en rigor, había ejercitado du derecho. ${ }^{498}$ El otro fallo celebre en la materia, es la sentencia de la Cour de Cassation, de 3 de agosto de 1915, recordada como "arrêt Clément Bayard," un sujeto instalo en su terreno un cercamiento que incluía estacas de madera de dieciséis metros de altura, coronado con barras de hierro puntiagudas, ubicadas con una separación de entre diez y treinta metros. En el fundo contiguo existía un hangar donde un ingeniero el Sr. Clément Bayard, fabricaba globos dirigibles para el ejercito. Uno de estos dirigibles resulto dañado por el cercamiento erigido por el vecino. El tribunal consideró inaceptable que un propietario colocara, sin demostrar cómo le resultaría provechosa y con menoscabo para el dueño de la finca contigua, una cerca en su tierra cuya altura excedía lo que era apropiado y necesario en aras a protegerse frente a intrusiones. De las circunstancias del caso, se infirió que el cercado fue construido con el único propósito de perjudicar a su vecino y se condeno no lo solo a indemnizar los daños y perjuicios provocados sino que también a retirar la instalación objeto del litigio. Véase, CUADRADO PÉREZ, La moderna..." Ob. Cit. p. 33.
} 
explícitamente sostiene las decisiones jurisprudenciales, el ejercicio de un derecho habrá de ser considerado abusivo cuando el titular carezca de un interés legitimo.

Sin perjuicio de lo expuesto, la verdadera concreción de la teoría del abusos del derecho, fue elaborada, en los términos modernos, por Josserand ${ }^{499}$ quien reacciona frente a la concepción exagerada de los derechos individuales, tal como se ha anotado, a los cuales opone la teoría de la relatividad, "[...] que lleva a admitir posibles abusos de los derechos [...]." ${ }^{500}$ Sostiene este autor, que cada derecho nace de la comunidad y que de ella además derivan su espíritu y finalidad, por lo que en consecuencia todos ellos son relativos y no absolutos, de tal manera que cuando se ejercen con desviación de ese fin, su titular ha incurrido en una falta y "[...] es precisamente esa culpa la que se llama abuso del derecho." 501

Para Josserand, todo el problema se reduce a determinar dos cosas: la función del derecho controvertido y la motivación que el titular del mismo ha tenido en vista para ejercitarlo. Si hay concordancia entre ambos, dicho derecho se ha ejercido válidamente, si no se produce el abuso. En suma, para nuestro autor el abuso del derecho se presenta como una desviación del derecho. ${ }^{502}$

A modo de síntesis, podemos señalar que durante el siglo $X X$, vieron la luz ideas solidaristas que reaccionaron contra el individualismo decimonónico, dando lugar a la doctrina del abuso del

\footnotetext{
499 JosserAND, El espíritu de los derechos ..." Ob. Cit.; También en, Del abuso del derecho y otros ensayos, versión de Carlos Valencia Estrada, Bogotá, Temis, 1982.

500 JosSERAND, Ob. Cit., p. 4.

501 JOSSERAND, Ob. Cit., p. 5.

502 JOSSERAND, Ob. Cit., p. 7.
} 
derecho en comento, según la cual se entiende que los derechos subjetivos no son absolutos, sino que están limitados por los derechos y los justos intereses de los demás miembros de la comunidad.

Dicho esto con palabras de Fernández Sessarego, "La admisión del abuso del derecho refleja, también, una vivencia más intensa, un arraigo mayor en la vida social, respecto del supremo valor de la solidaridad. La teoría del abuso del derecho surge así como una lógica reacción contra los códigos civiles que, inspirados en la filosofía del Código Civil francés de 1804, trasuntan una posición de corte netamente individualista. Por todo ello, el abuso del derecho representa, en la actualidad, un instituto indispensable para la convivencia humana, de suma importancia para edificar una sociedad más justa, solidaria y segura"

b.- Hipótesis de abuso del derecho en el deber de protección

i.- Criterios preliminares

De modo muy general podemos señalar, y sin entrar en las discusiones sobre su reconocimiento y naturaleza, ${ }^{504}$ podemos

\footnotetext{
${ }^{503}$ FERNÁNDEZ Sessarego, Ob. Cit., p. 3.

504 Importantes autores, como Planiol, Baudry-Lacantinerie, Duguit, etc., combaten duramente la expresión "abuso del derecho". En concepto de Planiol, no es posible hablar de tal abuso sin incurrir en una contradicción: o el acto es abusivo, y entonces no puede ser el ejercicio de un derecho, o está de acuerdo con éste, y en tal caso no puede haber abuso. Dice Planiol: "El derecho cesa, donde el abuso comienza y no puede haber uso abusivo de un derecho por la razón irrefutable de que un mismo acto no puede ser a la vez conforme y contrario al derecho. Puede haber abuso en la conducta de los hombres, pero ello no
} 
sostener que existen múltiples criterios para determinar cuándo se configura el abuso del derecho.

La posición mayoritaria los agrupan en subjetivos, objetivos y mixtos, seguiremos en esta materia al profesor Rodríguez-Arias. ${ }^{505}$

Para este autor, dentro del propósito de buscar un equilibrio en la teoría del abuso del derecho de forma de refutación del carácter absoluto de los derechos subjetivos, la doctrina y la jurisprudencia francesa conjugaron criterios distinguiendo dos fases: la subjetiva y la objetiva. Esta se refiere a la función social de cada uno de nuestros derechos, y aquella trata de investigar si la conducta del agente ha obedecido a un motivo legítimo. Por este procedimiento se logra una confrontación de los motivos del agente -elemento personal y subjetivo-, con la función del objeto del derecho -que es el elemento social y objetivo-.

Así, con una noción dualista de la teoría, conseguiremos una configuración ecuánime de la teoría del abuso del derecho, pues de una parte el criterio finalista, funcional u objetivo, se desprende del espíritu que informe los derechos subjetivos, el cual por sí solo sería más difícil de concretar debido a su carácter abstracto, pero al darse de otra la existencia de un motivo legitimo, que viene a impulsar al agente a actuar de cierta manera -elemento subjetivo- conseguiremos una expresión de la teoría del abuso más concreta y perfilada.

ocurre cuando ejercen sus derechos, sino cuando los exceden." PLANIOL, Marcel, Tratado Elemental de Derecho Civil, t. II., trad. José María Cajica, Puebla-México, 1945.

505 RodrígueZ-ARIAS, Lino, El abuso del derecho, ediciones jurídicas Europa-América, Buenos Aires, 1971, p. $127-129$. 
ii.- Infracción al deber: Ejercicio excesivo de un derecho

Como expusimos al inicio de este apartado, toda norma jurídica se refiere a la actividad del hombre frente a los demás, en el caso de nuestro particular objeto de estudio, es aún más patente esta idea, pues, se concreta en un deber específico que significa no ocasionar daños personales o patrimoniales en el ejercicio de los derechos que emanan de la relación obligatoria en afán de la realización de la prestación.

Como describe Josserand, ${ }^{506}$ en el derecho de los contrato se descubrirá un nueva función y aspecto de la teoría del abuso, pues condiciona y atenúa no ya prerrogativas legales, que se pretenden absolutas, sino relaciones obligatorias que son obra de las voluntades de las partes privadas y cuyo carácter relativo tiene un valor casi constante.

Las obligaciones son prerrogativas sociales, destinadas a realizarse social y equitativamente, las cuales deben prepararse, celebrarse, ejecutarse y terminar en una atmósfera saludable y no viciada según los estándares de la buena fe.

En relación a la ejecución de los contratos, se sigue que en la práctica, las partes no prevén expresamente todas las eventualidades posibles, ya que, en la generalidad de los casos su acuerdo expreso se limita a lo esencial. En caso de conflicto la ley o los tribunales

${ }^{506}$ JOSSERAND, Ob. Cit., p. 76-99 
interpretan y suplen su voluntad, no arbitrariamente, sino de acuerdo con el espíritu del contrato -naturaleza- con un sentido de equilibrio y equidad.

De lo que se desprende que cualquier determinación absoluta efectuada sin respeto alguno a los intereses de la contraparte, rompe el equilibrio y relatividad de los derechos prestacionales, importando con ello un acto abusivo, por cuanto, la parte sometida debe aceptar una decisión aunque licita, absoluta del interés de prestación, usado libre e ilimitadamente en cuanto a tal.

La doctrina encaminada por Josserand, distingue tres clases de actos: el ilegal, el ilícito y el excesivo. El primero, es antijurídico en sí mismo, el segundo, lo es por el objeto al cual es consagrado, y el tercero, no es productivo de la responsabilidad más que en razón del exceso o anormalidad del daño de que él resulta para otro.

Es este último, es el que suscita toda nuestra atención, dado que, la determinación absoluta de los derechos prestacionales, se comprenden en su contenido. Por cuanto, configura claramente un abuso el ejercicio de un derecho licito en su origen y finalidad, pero sin atenderse a los intereses ajenos o sin tomar en cuenta las reglas de la prudencia, o sea, con franca desconsideración hacia los derechos ajenos. $^{507}$

El ejercicio anormal o excesivo de un derecho comporta la visión objetiva de la teoría, es decir, de trazar ciertos limites a todo

507 RodrígueZ-Arias, Ob. Cit., p. 141. 
ejercicio del derecho, en función del binomio utilidad propia-daño ajeno. $^{508}$

Como señala Cuadrado Pérez: "La clave se halla, por lo tanto, en determinar los confines de cada derecho subjetivo, toda vez que debemos considerar vencida la concepción absolutista de los mismos. Es aquí, verdaderamente donde podemos localizar el logro alcanzado por la contemporánea doctrina del abuso del derecho, y no parece razonable admitir una regresión que represente un retorno a la teoría de la emulación."

El acto anormal o excesivo no hace referencia a la intensión de quien ejercita su derecho, sino al resultado objetivo del tal ejercicio, fruto de apurar demasiado las ventajas que éste es susceptible de procurar a su titular. ${ }^{510}$ Es decir, aunque no se conozca la intensión de quien ejercita su derecho, cabrá apreciar su carácter abusivo si el resultado del acto se sitúa al margen de la ratio de la tutela de la esfera de poder de aquel. ${ }^{511}$

¿Pero que debemos entender materialmente como un acto normal ${ }^{512}$ para Martin Bernal, ${ }^{513}$ significa un uso que no exceda las

\footnotetext{
${ }^{508}$ Rivero Hernández, Francisco, Elementos de derecho civil. $T$ I, Parte general del derecho civil. $3^{\circ}$, El derecho subjetivo, José Luis Lacruz Berdejo, Agustín Luna Serrano, Francisco Rivero Hernández, Bosch, Barcelona, 1984, p. 119.

${ }^{509}$ CUADRADO PÉREZ, La moderna..." Ob. Cit. p. 92.

${ }^{510}$ RIVERO HERNÁNDEZ, Ob. Cit., p. 125.

${ }^{511}$ CuAdRAdo PÉREZ, La moderna...” Ob. Cit. pp. 93-94.

${ }^{512}$ Los criterios de uso normal y tolerancia, fueron examinados en primer término bajo la luz de la teorías de las inmisiones, en especial en dos autores Bonafante y Jhering. El primero, nos dice que cuando alboreó la teoría del uso normal lo fue inspirada en concepto de la inmisión, tratando de establecer una líneas de demarcación entre las inmisiones ilícitas y las licitas, La teoría del uso normal conciliaba dos puntos de vista opuestos: están prohibidas (además de las inmisiones directas) aquellas inmisiones indirectas que derivan de un uso extraordinario que exceda las necesidades y de la esfera de la vida normal; están permitidas las que derivan de las necesidades de la vida cotidiana. La teoría de
} 
necesidades normales de la vida, no cabe establecer formulas rígidas por que resultaría insuficiente e inadecuada, es propiamente un estándar jurídico, que pone en juego la racionalidad o equilibrio de la sana composición de intereses de sociales, económicos y morales, emergentes de la vida que en un lugar y en una época, sobrelleven las personas, constituirá un precioso instrumento para que el juez decida, según las circunstancias de la especie y de acuerdo con la mayor o menor gravedad de los hechos que determine o no su carácter excesivo, intolerable, no ordinario, anormal en suma.

En este mismo sentido, subraya Cuadrado Pérez: “ $A$ pesar de que todas estas acepciones acrecientan la denunciada vaguedad de la doctrina del abuso del derecho, resulta inoperante atribuirle una significación más concreta, ya que, cualquier tentativa de precisión colisiona con la propia esencia del concepto de circunstancias, al que es inherente la indeterminación. Por otra parte, por definición, el abuso de derecho no puede perfilarse detenidamente con carácter previo"514

En nuestra opinión, respecto al particular objeto de estudio que examinamos, existe una conexión intensa entre la infracción del deber de protección y el ejercicio de un acto excesivo y anormal, por cuanto, el contenido de este último, como estándar jurídico, puede ser completado mediante la buena fe contractual, como un criterio útil para determinar si el ejercicio de un derecho resulta abusivo,

\footnotetext{
Jhering, por su parte, surge como superadora de esa pacifica visa domestica y dentro de un tipo de actividad ya industrial, dándole una base mucho más amplia al adoptar el criterio del uso normal, por cuanto la prohibición alcanzaba todo flujo directo o indirecto sobre el fundo vecino, pecando quizá de un exceso en sus aplicaciones. Véase, MARTIN BERNAL, José Manuel, El abuso del derecho, Montecorvo S.A, Madrid, 1982, pp. 215.

513 MARTIN BERNAL, Ob. Cit., pp. 212-213.

${ }^{514}$ CuAdRAdo PÉREZ, La moderna..." Ob. Cit. p. 95.
} 
impondrá a su titular, el deber de llevarlo a cabo con respeto a los principios de corrección social, lealtad, solidaridad y seriedad.

Este contenido representa, que para que el acto se considere normal y no excesivo, su titular debe observar unas determinadas reglas de comportamiento impresas por la buena fe, cuya contravención le imponen la obligación de indemnizar cuando la parte se ha visto perjudicada, es decir, se trata de conciliar la libertad del titular del derecho, -que en principio resulta incoercible- con la exigencia de imponerle un comportamiento respetuoso de los intereses de otros terceros, para evitar que el ejercicio de su derecho pueda transformarse en fuente de daños excesivos para otros.

Finalmente podemos sostener que, efectivamente los deberes de protección representan en la relación obligatoria un limite cierto al ejercicio absoluto de los derechos subjetivos de las partes.

Su inobservancia o vulneración, constituye un acto abusivo, por cuanto importa un ejercicio excesivo o anormal del interés de prestación, pues, cualquier actividad que en involucre daño a la persona o patrimonio de la contraparte, aunque sea lícita y en pos de la realización de la prestación principal, sobrepasa con creces los limites normales del interés propio. 
a.- Noción

La configuración dogmática del Soft Law se realiza en el marco del Derecho internacional $\mathrm{y}$, en particular, en el ámbito de las organizaciones internacionales.

Añadido a lo anterior, y como punto de partida, hemos de destacar que el término Soft Law o derecho blando, fue acuñado por Lord Mc Nair, ${ }^{515}$ pretendiendo realizar una distinción entre las proposiciones de lege lata y lege ferenda.

El Soft Law juega un papel preponderante en el ámbito de producción normativa internacional, como indica Barberis: "El orden Internacional actual no constituye un orden cerrado en el que existe un número determinado de creación de normas jurídicas. Los miembros de la Comunidad Internacional pueden acordar nuevas fórmulas para crear el Derecho de gentes" ${ }^{516}$ En este contexto se ubica el fenómeno del Soft Law, también denominado derecho blando, derecho flexible o pre-derecho, cuyo principal punto de interés es el papel que desempeña en la formación del Derecho.

El Soft Law es un término complejo y que carece de un significado unívoco, pudiendo incluirse en el mismo una infinita variedad de formas y manifestaciones. No obstante lo anterior, la posición generalizada de la doctrina es considerar que el fenómeno

\footnotetext{
${ }^{515}$ DuPUY, René-Jean, "Droit déclaratoire et droit programmatoire: de la costume sauvage á la soft law", en L'élaboration du droit international public, Société française pour le Droit international, Colloque de Toulouse, 1975, p. 139.

${ }^{516}$ BARBERIS, Julio, Formación de Derecho Internacional, Editorial Abaco, Buenos Aires, 1994. p. 257.
} 
del Soft Law aparece cuando el instrumento tiene un carácter jurídicamente no vinculante y posee cierta relevancia jurídica, siendo su espacio natural de producción el Derecho internacional, aún cuando se esté extendiendo, en la actualidad y por su influencia, a los derechos domésticos. ${ }^{517}$

En el aspecto gubernamental, en el contexto actual de globalización económica cada vez con mayor frecuencia e intensidad los diferentes Estados se ven obligados a reformar su ordenamiento siguiendo el Soft Law, dado que en caso contrario pueden sufrir determinado tipo de contramedidas por parte de las organizaciones e instituciones que las han dictado. ${ }^{518}$

Nuestra intensión, no es referirnos o debatir sobre la naturaleza jurídica del Soft Law o sobre su posición jerárquica en el sistema de fuentes, del cual existe bastante discusión en la doctrina. Si no, de resaltar algunos características de dicho fenómeno, referentes a principios y normas generales, como posibles aplicaciones de apoyo en la práctica en relación a nuestro particular objeto de estudio.

\section{b.- Soft Law privado: Principios}

\footnotetext{
${ }^{517}$ Véase entre otros, Del TORO HUERTA, Mauricio, "El fenómeno del Soft Law y las nuevas perspectivas del Derecho Internacional", Anuario Mejicano de Derecho Internacional, vol. VI, 2006, p. 535; Alonso GARCíA, Ricardo, "El Soft Law Comunitario", Revista de Administración Pública, Madrid, Núm. 154, Enero-Abril 2001.pp. 63-94; SARMIENTO Ramírez-Escudero, Daniel, "La autoridad del Derecho y la naturaleza del soft law", en Cuadernos de Derecho Público, Nº 28, 2006, pp. 221-261.

518 CAAMAÑo ANIDO, Miguel Ángel y CALDERÓN CARRERo, José Manuel, "Globalización Económica y Poder Tributario: ¿Hacia un nuevo Derecho Tributario?", en Revista española de derecho financiero, Civitas, № 114, 2002, p. 263.
} 
El Soft Law no es derecho vigente, sino derecho académico, por ello tiene interés observar la influencia indirecta que ejerce en la actividad legislativa interna y en la jurisprudencia de cada país, en la medida en que ésta no es forzada, sino fruto de la persuasión y del convencimiento de la calidad del derecho que ejerce su influjo.

En ámbito del derecho privado, el Soft Law ha proporcionado pautas valiosas a la jurisprudencia en la modernización de aspectos del derecho de obligaciones y del derecho de daños, y otras corrientes internacionales de constante desarrollo.

\section{i.- Principios de Derecho Europeo de la Responsabilidad Civil}

Principios de Derecho Europeo de la Responsabilidad Civil del European Group on Tort Law, comienzan consagrando una norma elemental que envuelve todo el respectivo cuerpo normativo.

Así, en el Art. 1:101., bajo el epígrafe "Norma fundamental," expone: "Que la persona a quien se pueda imputar jurídicamente el daño sufrido por otra está obligada a repararlo." Con ello la norma fundamental destaca, en primer ligar, uno de los presupuestos generales de responsabilidad, a saber, que la otra persona haya sufrido un daño. En segundo lugar que el Derecho de la responsabilidad civil aspira a la compensación de ese daño. ${ }^{519}$

\footnotetext{
${ }^{519}$ Principios de Derecho Europeo de la Responsabilidad Civil del European Group on Tort Law, AA. VV., (Coord.) Miquel Martín-Casals, trad. (REDPEC), Aranzadi, Navarra, 2008, p. 49.
} 
Posteriormente, dicho cuerpo normativo efectúa una mención expresa al deber de proteger a los demás, en su Art. 4:103., señala: "Puede existir el deber de actuar positivamente para protegerá los demás de daños si así se establece legalmente, si quien actúa crea y controla una situación de peligro si existe una especial relación entre las partes o si la gravedad del daño para una parte y la facilidad de evitarlo para la otra indican la existencia de tal deber.

Lo anterior, hay que asociarlo a los intereses protegidos por los Principios de Derecho Europeo de la Responsabilidad Civil, esto es, donde en primera línea se encuentra la vida, la integridad física y psíquica, la dignidad humana y la libertad (Art. 2:102. [2] ).

Este reconocimiento manifiesto, configura un precedente importantísimo en el campo de nuestro estudio, ya que, elevan el deber positivo de protección de ciertos intereses, a una categoría en el Derecho de la responsabilidad civil.

Esta inclusión, se debe a la evolución del Derecho moderno, que ha marcado una tendencia en ampliar en campo de los deberes de actuar y de proteger los intereses de los demás. Una expresión manifiesta de esa tendencia la constituye el reciente desarrollo judicial, en especial en Alemania y Suiza, de la llamada responsabilidad basada en la confianza (Vertrauenshaftung).

La idea de fondo, es conectar el concepto de deberes implícitos en Derecho contractual (Scutzpflichten), considerando un violación del principio de la buena fe y, en consecuencia, una conducta antijurídica y culpable, tener conocimiento suficiente y no advertir o informar a 
otra persona que claramente confía en una percepción falsa o engañosa de los hechos o problemas relevantes. ${ }^{520}$

ii.- Otros cuerpos normativos

En los principios UNIDROIT, en relación con nuestro objeto de estudio, el art. 5.1.1 indica expresamente que las obligaciones contractuales de las partes pueden ser expresas o implícitas, mientras que su art. 5.1.2 puntualiza que las obligaciones implícitas pueden derivarse, entre otros factores, de la buena fe, de la lealtad negocial y el sentido común.

La misma idea está presente en los apartados (1) y (2) del art. II-9:101 del DCFR. Así, el número (1) señala: "Los términos de un contrato pueden derivar de el acuerdo expreso o tácito de las partes, [...]" Por su parte el número (2) expresa: "Cuando sea necesario prever un asunto que las partes no hayan previsto o previsto, un tribunal puede implicar un término adicional, teniendo en cuenta en particular: (A) la naturaleza y finalidad del contrato; (B) las circunstancias en las que se celebró el contrato; y (C) las exigencias de la buena fe contractual. (3) Cualquier condición implícita en el párrafo (2) debe, en lo posible, ser tal como para poner en práctica lo que las partes, tuvo que prestaron a la materia, [..]"

${ }^{520}$ Principios de Derecho Europeo de la Responsabilidad Civil... Ob. Cit., p. 127. 
En consecuencia, en relación al ámbito del Derecho de contratos, estos cuerpos normativos, dejan la puerta abierta a integrar el iter contractual con los deberes secundarios de prestación como es el caso del deber de protección que surgirán entre las partes mediante la buena fe contractual. 


\section{Capítulo cuarto}

\section{LOS DEBERES DE PROTECCIÓN EN EL SISTEMA DE Responsabilidad Civil Chileno}

Como hemos tenido varias veces la oportunidad de afirmar, los deberes de protección, proponen la idea de que en la relación obligatoria, junto al interés fundamental acreedor a la realización de la prestación, existe otro interés consistente en que del vínculo no deriven daños para la persona o el patrimonio de cualquiera de las partes de la relación obligatoria.

La inserción de estos deberes en el ámbito del contrato, genera una contractualización de los daños, incorporando a este escenario, los atentados a la integridad física, psíquica y patrimonial de los contratantes. De este modo la noción de responsabilidad contractual resulta ampliada, pues junto a la responsabilidad por el incumplimiento en sentido estricto -derivada de la violación del deber de prestación- aparecen supuestos de violación de deberes de protección que se refieren a intereses diversos. ${ }^{521}$

Así, la inobservancia del deber de protección produce responsabilidad por violación de la relación obligatoria, ${ }^{522}$ generando

\footnotetext{
521 JORDANO FRAGA, La responsabilidad...”, Ob. Cit., p. 142.

522 Dicha responsabilidad civil, que denominaremos ocupando la nomenclatura expresada por Castronovo, "relacional," explica la violación de la relación obligatoria, en toda su
} 
una serie de incidencias en el campo de la responsabilidad civil, este tipo de consecuencias, a las cuales nos avocaremos en el presente capítulo, comprenden como veremos, una absorción a la sede contractual de los daños ocasionados entre las partes de la relación obligatoria de origen no prestacional, y respecto de ciertos terceros crearán un régimen especial por la violación del deber de protección.

\section{I.- INFRACCIÓN DE LOS DEBERES DE PROTECCIÓN: Y SUS EFECTOS RESPECTO LAS PARTES}

1.- INOBSERVANCIA DEL DEBER DE PROTECCIÓN: EXTENSIÓN DE LA ORBITA CONTRACTUAL

Junto al incumplimiento en sentido técnico, emanan supuestos de trasgresión de deberes secundarios de prestación, que vinculados generalmente por la buena fe, ensanchan la estructura del vínculo obligacional.

Bajo este contexto, la deuda comporta una serie de obligaciones que no guardan relación directa con el interés de prestación, sino, como señalábamos, tienden a preservar otros intereses de las partes que pueden verse lesionados en la dinámica de la relación obligatoria. ${ }^{523-524}$

integridad, ya sea, que tenga su origen en la estipulación de las partes o por la inclusión de un deber secundario

523 JIMÉNEZ HORWITZ, Margarita, La imputación al deudor en incumplimiento ocasionado por sus auxiliares, McGraw-Hill, Madrid, 1996, p. 55.

524 JOURDAIN, "Le fondement..." Ob. Cit., p. 23. 
La razón de ello, radica en que extender la esfera de relevancia de la obligación más allá de la prestación principal, importa tomar en consideración todos los deberes e intereses, que concurren al objetivo de preparar e integrar el cumplimiento de forma tal, que la satisfacción sea completa y plena. ${ }^{525}$

Al respecto expone Jordano Fraga: "La consideración de los deberes de protección, imponen la reafirmación del carácter complejo de la relación obligatoria, de la que surgen, junto al deber de prestación primario, una serie de deberes integrativos de contenido autónomo que en ella tienen su origen y que, consiguientemente, al ser violados producen un ensanchamiento de la responsabilidad contractual. ${ }^{526}$

Pues bien, verificada la infracción al deber de protección, se genera la correspondiente responsabilidad contractual por los daños ocasionados a intereses no prestacionales.

Los criterios para inclusión de estos daños, como ya sabemos ${ }^{527}$ suponen una correspondencia funcional con el objeto de la obligación principal, es decir, estos deben porvenir de una actividad vinculada a la ejecución de la relación obligatoria y no solo con ocasión del mismo.

La infracción del deber en comento, produce una serie de alteraciones en el sistema de responsabilidad civil, por cuanto, dado

\footnotetext{
${ }^{525}$ VISINTINI, Ob. Cit., p 32.; ScognAMIgliO, Ob. Cit., 675.

526 JORDANO FRAGA, La responsabilidad..., Ob. Cit., p. 145.

${ }^{527}$ Véase, Supra, pp. 158 y ss.
} 
su carácter autónomo, ${ }^{528}$ generará responsabilidad aún cuando la prestación principal este cumplida satisfactoriamente. Nace en consecuencia el derecho de la víctima a la reparación de los daños ocasionados en su integridad física, psíquica o patrimonial en virtud de la ejecución del contrato.

a.- Remedio contractual

La consecuencia fundamental que deriva de la infracción del deber de protección, es el derecho de la víctima a la indemnización de daños y perjuicios.

Este asunto resulta particularmente pacífico en la doctrina alemana, francesa, española e italiana, ${ }^{529}$ toda vez que, no genera mayores dudas que la infracción de los deberes de protección implica que el deudor queda obligado al resarcimiento de daños y perjuicios no prestacionales ocasionados. ${ }^{530}$

Para Di Majo, una vez aceptada la idea de que el deber de protección forma parte del contenido de la relación contractual, no es lógico negar al mismo el título de tutela (específica) que corresponde al deber de prestación.

\footnotetext{
${ }^{528}$ Véase, Supra pp. 132 y ss.

${ }^{529}$ DI MAJO, Ob. Cit., p. 126 y 322.; MedICUS, Schuldrecht..." Ob. Cit., pp. 194-195.; LARENZ, Lehrbuch...." Ob. Cit., p. 367; DeLEBEQUECQUE, Philippe, "La dispersion des obligations de sécurité dans les contrats spéciaux" en La naissance de l'obligation de sécurité, Gazette du Palais, 1997, pp. 10-11.; JORDANO FRAGA, La responsabilidad del deudor..." Ob. Cit., p. 237. ${ }^{530}$ DI MAJO, Ob. Cit., p. 126 y ss.
} 
Por su parte, Cabanillas Sánchez, sostiene que en España a igual como acontece en el Derecho alemán, el efecto de la imposición de los deberes obligacionales de protección o de seguridad, es que los daños ocasionados por el deudor, como consecuencia de una actividad de cumplimiento descuidada o desatenta, en bienes jurídicos del acreedor no estrictamente atinentes al objeto de la obligación, quedan sujetos, para su indemnización, al mismo régimen que el de las infracciones de los también obligacionales deberes (principales) de prestación: el de la responsabilidad contractual (con su régimen de prueba y plazo). ${ }^{531}$

En Chile, -como argumentaremos- no existe inconveniente para que los daños derivados de la inobservancia de los deberes de protección sean reparados por la vía del remedio contractual de la indemnización de perjuicios.

b.- Indemnización de perjuicios autónoma

Con la recepción formal del nuevo Derecho de la contratación por parte del Estado de Chile mediante la ratificación la Convención de las Naciones de Unidas de Vienna de 1980 sobre los contratos de compraventa internacional de mercaderías (CISG O CV), ${ }^{532}$ se

\footnotetext{
${ }^{531}$ CABANILLAS SÁNCHEZ, Los deberes de protección ..." Ob. Cit., p. 456.

${ }^{532}$ La Convención de las Naciones de Unidas sobre los contratos de compraventa internacional de mercaderías es ley de la república desde el 3 de octubre de 1990.
} 
reemplaza la noción subjetiva de incumplimiento contractual por sentido amplio y objetivo. ${ }^{533}$

A partir de tal reformulación, surge un abanico de remedios para el acreedor insatisfecho, entre los que destaca la indemnización de perjuicios. Ante el incumplimiento contractual el ordenamiento jurídico debe propender a satisfacer no solo la prestación insatisfecha del acreedor, sino también lograr una reparación integra de los daños y perjuicios causados. ${ }^{534}$

Lo anterior, se explica por que la finalidad de la indemnización de perjuicios como remedio contractual, es la reparación integral ${ }^{535}$ de los perjuicios derivados de la lesión del relación obligatoria como consecuencia del incumplimiento, en cuanto esté constituye una alteración del efecto normal de la obligación.

La reparación integral solo se alcanza otorgando a la indemnización de perjuicios por incumplimiento contractual un carácter autónomo, dado que el resarcimiento así concebido permite

\footnotetext{
${ }^{533}$ Para Vidal: "El incumplimiento es un hecho objetivo que se identifica con cualquier desviación del programa de prestación respecto de la conducta desplegada por el deudor en cumplimiento del contrato. Ese incumplimiento, carente de una valoración subjetiva, es el que permite articular el sistema de los remedios de que dispone el acreedor y entre los cuales puede optar más o menos libremente." VIDAL OLIVARES, Álvaro, "Cumplimiento e Incumplimiento contractual en el Código Civil. Una perspectiva más realista”, en Revista Chilena de Derecho, № 34, Santiago, 2007, p. 41.

${ }^{534}$ Ya los autores tradicionales chilenos reconocían la doble función de la responsabilidad contractual, en compensatoria y reparadora. Véase, FUEYO LANERI, Ob. Cit., p.332.; AlesSANDRI RodRíguez, Arturo, De la responsabilidad extracontractual en el Derecho Civil Chileno... Ob. Cit., p. 42.

${ }^{535}$ La responsabilidad contractual cumple con una función reparadora, tanto en la esfera patrimonial como en la extrapatrimonial, por cuanto, las reglas que gobiernan las consecuencias del incumplimiento contractual deben satisfacer de manera integra al acreedor. No debe importar si se trata de una obligación de dar, hacer o no hacer. La responsabilidad contractual debe permitir reconstruir el patrimonio y compensar los daños en su integridad. Véase, PIZARRO WILSON, Carlos, "La responsabilidad contractual en el Derecho Civil chileno", en Fabricio mantilla (coord.), Problemas de Derecho de los Contratos, Bogotá, Editorial Legis, 2007, pp. 215-217.
} 
indemnizar íntegra y totalmente al acreedor el perjuicio ocasionado por el deudor incumplidor. ${ }^{536}$ Esta función implica que las reglas de responsabilidad contractual deben tener como finalidad dejar intacta la esfera patrimonial y personal del acreedor.

En Chile, desde hace algunos años nuestra doctrina ha postulado la procedencia de la indemnización autónoma, directa o exclusiva por inejecución contractual, invocando diversos argumentos, tales como el libre derecho de opción del acreedor entre las acciones o remedios contractuales, la reparación integral del daño, la interpretación lógica y sistemática del artículo 1489 del Código Civil chileno y el carácter principal de la obligación de indemnizar. ${ }^{537}$

Por su parte, dicha argumentación ha sido recogida recientemente por la Corte Suprema de Justicia, incluso tratándose del incumplimiento de obligaciones de dar, superando así los inconvenientes que acarreaba la corriente de pensamiento según la cual la indemnización de daños por inejecución contractual solo podía demandarse en forma concurrente, complementaria y accesoria al cumplimiento específico o a la resolución del contrato. ${ }^{538}$

\footnotetext{
${ }^{536}$ El principio de reparación integral se encuentra reconocido en el nuevo Derecho de la Contratación, específicamente en el artículo 74 de la CV, artículo 9.501.2 de los de los PECL, artículo 7.4.2. de los Principios UNIDROIT.

${ }^{537}$ Sobre la indemnización de perjuicios como remedio contractual autónomo, véase el interesante estudio sobre la materia en LÓPEZ DÍAZ, Patricia "La indemnización compensatoria por incumplimiento de los contratos bilaterales como remedio autónomo en el derecho civil chileno" en Revista Chilena de Derecho Privado, № 15, 2010, pp. 65-113.; también en "La autonomía de la indemnización de daños en la jurisprudencia nacional reciente: ¿un cambio de paradigma?" en Revista Chilena de Derecho Privado, № 23, 2014, pp. 139-207.; también en La autonomía de la indemnización de daños por incumplimiento de un contrato bilateral en el Código civil chileno, Legal Publisher, Santiago, $1^{\text {a }}$ ed., 2015.

${ }^{538}$ En lo que concierne a la libre opción del acreedor, la interpretación lógica de las disposiciones del Código Civil chileno y la reparación integral del acreedor véanse el considerando cuarto de la sentencia Faúndez Mora con Compañía de Telecomunicaciones de Chile S.A. (2011), décimo cuarto y décimo sexto la sentencia Opazo Lamana con Inmunomédica Laboratorio Ltda. (2010), séptimo de la sentencia Asociación de
} 
En relación a los deberes de protección, estos se desenvuelven generalmente en la práctica como obligaciones de hacer (deberes de aviso y custodia) y no hacer (deberes de conservación y salvamento). De lo que se sigue, que no existe inconveniente jurídico válido, aún en la tesis más restrictiva para negarle autonomía a la indemnización de perjuicios por infracción de un deber de protección en la relación obligacional. Pues, las reglas del Código civil en la materia, prevén explícitamente esta posibilidad.

Una lectura del numeral tres de artículo 1553 del Código Civil chileno nos lleva a la irrefutable conclusión, que tratándose de la inejecución de una obligación de hacer el acreedor está facultado para demandar la indemnización de perjuicios exclusiva. Dicho numeral es claro: el acreedor podrá solicitar que el deudor "le indemnice de los perjuicios resultantes de la infracción del contrato". ${ }^{539}$

Tratándose de la obligaciones de no hacer, el resultado es idéntico, evidenciando con ello la preferencia del legislador su hacia la indemnización autónoma como remedio contractual, por cuanto, el articulo 1555 del Código civil en su inciso $1^{\circ}$ señala: "Toda obligación de no hacer una cosa se resuelve en la de indemnizar los perjuicios, si el deudor contraviene y no puede deshacerse lo hecho", finalizando en el ultimo inciso de dicho artículo con la expresión: "El acreedor quedará de todos modos indemne".

Productores de Huevos de Chile con Banco de Chile (2011), cuarto de la sentencia Reyes Valdivia con Escuela de Tripulantes y Portuaria (2012), vigésimo de la sentencia Ampuero Ascencio con Castillo Hernández (2013), décimo octavo de la sentencia Steffen Cáceres con Fundación Mi Casa (2013) y décimo noveno de la sentencia Stange Hoffman con Ripley Puerto Montt (2013), y curo, quinto y sexto de la sentencia Laboratorios Control técnico Llay Llay Ltda. con Celestron Ltda. (2014).

${ }^{539}$ LÓPEZ DíAZ, "La autonomía de la Indemnización..." Ob. Cit., p. 154. 
A mayor abundamiento, en el caso de los deberes de protección que comprende conductas de abstención u obligaciones de no hacer, su contravención siempre constituirá un hecho material, por lo que, en dichos términos resulta física y jurídicamente imposible deshacerlo o destruirlo, por lo que deberá invariablemente ser indemnizado.

C.- Daños indemnizables

En relación a los daños indemnizables, se aplicaran las mismas reglas que para cualquier otra lesión de la relación contractual, tanto en la entidad del daño como en la carga de la prueba, ya que, la infracción de un deber de protección importa como hemos señalado, genuina responsabilidad por incumplimiento contractual.

En este sentido argumenta Jordano Fraga: "El efecto de la imposición de estos deberes obligacionales-específicos de protección o seguridad, es, como resulta sabido, que los daños ocasionados por el deudor, como consecuencia de una actividad de cumplimiento descuidada o desatenta, en bienes jurídicos del acreedor no estrictamente atinentes al objeto de la obligación, quedan sujetos, para su indemnización, al mismo régimen que el de las infracciones de los también obligacionales-específicos deberes de prestación: el de la responsabilidad contractual (con su régimen de prueba y plazo), y no el de la extracontractual. Y ello es así, en la medida en que resulta vulnerado no ya un deber general o indiscriminado del tráfico, sino un 
deber específico que una determinada obligación imponía al concreto deudor frente a su preciso acreedor. ${ }^{, 540}$

A mayor abundamiento, en relación a la carga de la prueba, como hemos afirmado, el deber de protección corresponde en cuanto a su naturaleza a una obligación de resultado, ${ }^{541}$ ello trae consigo la aplicación del régimen de este tipo de obligaciones, es decir, el cumplimiento de la obligación requiere, la plena satisfacción del interés del acreedor, no siendo suficiente para estos efectos la mera conducta del deudor encaminada a satisfacerlo. En el caso en comento, el resultado de la obligación de seguridad, es la indemnidad de la persona y patrimonio de la contraparte, de los que se sigue, que en el evento de inobservancia del deber, se entiende que el deudor no alcanza el resultado que satisface el interés del resultado. ${ }^{542}$

En cuanto a la amplitud de los daños, la noción objetiva del incumplimiento contractual, viene a ratificar la naturaleza funcional de los deberes de protección en la relación obligacional. Pues al tratarse, el incumplimiento de un hecho objetivo, desprovisto de toda valoración subjetiva, solo vasta la infracción formal al deber de protección para que se genere la correspondiente responsabilidad, escapando al criterio de previsibilidad en el sentido técnico del artículo 1558 del Código civil chileno.

Sobre este particular, como los deberes de protección en la mayoría de los casos se tratan de obligaciones implícitas, incorporadas a la relación obligatoria por la clausula general de la

\footnotetext{
540 JoRdANO FRAGA, La responsabilidad...”, Ob. Cit., pp. 236-237.

541 Véase, Supra pp. 149 y ss.

542 CABANILlAS SÁNCHEZ, Las obligaciones de actividad... Ob. Cit., p 124.
} 
buena fe, su infracción, comprende siempre un juicio de previsibilidad amplio y tácito, que incorpora implícitamente todos los eventuales daños que por la naturaleza de la obligación haga razonable pensar que circunstancias inherentes a la convención tornen necesario afianzar la protección de la indemnidad de uno de los contratantes.

Una cuestión interesante, se presenta con la reparación de daños extrapatrimoniales, en especial con el daño moral. En Chile, la Corte Suprema ha aceptado expresamente el daño moral ${ }^{543}$ en sede contractual esgrimiendo el derecho a la integridad psíquica. ${ }^{544}$

No obstante, en relación a la infracción del deber de protección, la lesión a intereses extrapatrimoniales como el daño moral, es más directa y efectiva. Por cuanto, resulta de la esencia de los deberes de protección a la integridad de la persona, de la injerencia dañosa de la contraparte, a los intereses no prestacionales de la relación contractual. De lo que se sigue, que la sola vulneración al deber de protección importa la reparación efectiva de la esfera tanto física como psicológica del contratante lesionado.

Esta vía de reparación del daño moral basado en la inobservancia del deber de protección, funda la reparación del daño en un incumplimiento propia y directamente contractual, sin ninguna

\footnotetext{
${ }^{543}$ Sobre el daño moral contractual véase DomíngUEZ HIDALGO, Carmen, "La indemnización por daño moral. Modernas tendencias en el derecho civil chileno y comparado", en Revista Chilena de Derecho, vol. 25, № 1, 1998, pp. 27-55; "algunas consideraciones en torno al daño como elemento de la responsabilidad civil", Revista de Derecho, Universidad Católica de Valparaíso, 1998; JANA LINETZKY, Andrés y TAPIA RODRÍGUEZ, Mauricio, "Daño moral en la responsabilidad contractual a propósito de un fallo de la Corte Suprema de 5 de noviembre de 2001, en Cuadernos de Análisis Jurídico, Colección Derecho Privado, № 1 , 2004, p. 171 y ss.

${ }^{544}$ Corte Suprema, 20 de octubre de 1994, Gaceta Jurídica No 174, 1994, p. 155; Corte de apelaciones de Santiago, 6 de agosto de 1996, Gaceta Jurídica N ${ }^{\circ} 194,1996$, p. 70; Corte de apelaciones de Concepción, 19 de enero de 1990, Gaceta Jurídica № 122, 1990, p. 31.
} 
desviación del programa prestacional, ya que, la infracción del deber emana de la naturaleza de la convención integrada por la buena fe. Lo que hace una construcción y posterior reparación del daño moral mucho más robusta y justificada.

2.- DEBER DE PROTECCIÓN Y LA RESPONSABILIDAD CONTRACTUAL INDIRECTA

El considerable desarrollo industrial y tecnológico que ha experimentado la moderna sociedad global, han traído como consecuencia una creciente complejidad de los procesos productivos y una marcada tecnificación del trabajo.

Estas circunstancias, han originado que los contratantes en la actualidad se sirva normalmente de terceros en el cumplimiento de sus obligaciones contractuales. Este tipo de escenario contractual se denomina responsabilidad contractual indirecta o también llamada responsabilidad contractual por hecho ajeno, y se configura cuando el deudor utiliza auxiliares para el cumplimiento de la relación obligatoria.

Este tipo de responsabilidad se encuentra asentada y reconocida en la generalidad de la doctrina moderna. ${ }^{545}$ Lo que

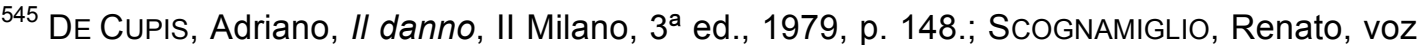
"Responsabilità per fatto altrui" en Novissimo Digesto italiano XV, Torino, 1968, p. 691.; FERRARA, Francesco, "Responsabilidad contrattuale per fatto altrui" en Archivio de Giuridico, vol. LXX, 1903, pp. 401 y ss.; BÉNAC-SCHMIDT, Françoise, LARROUMET Christian, voz "Responsabilité du fait d'auntri" en Enciclopedia Dalloz civil, Paris, 1990, núm. 12.; MESSINEO, Francesco, Manual de Derecho Civil y .... Ob. Cit., p. 236.; De ANGel YÁGúEZ, Ricardo, La responsabilidad civil, $2^{\mathrm{a}}$ ed. Universidad de Deusto, Bilbao, 1989, pp. 115 y ss.; SANTOS BRIZ, Jaime, La responsabilidad civil. Derecho sustantivo y Derecho procesal, I, $5^{\mathrm{a}}$ ed., Madrid, 1989, pp. 455 y ss.; Lacruz, Elementos de Derecho Civil..." Ob. Cit., pp. 563 y
} 
caracteriza esta responsabilidad es la disociación entre el sujeto responsable y el sujeto causante del daño, es decir, la división se encuentra entre la causación material del daño y la imputación jurídica del mismo.

En este orden de ideas, la figura de la responsabilidad indirecta otorga a nuestro objeto de estudio un reconocimiento expreso, dado que, con ella se acentúa la extensión de la protección en la orbita contractual, a los daños ocasionados por el auxiliar, sin importar que sean estos causados a los intereses prestacionales o los interés de protección.

De ahí que sostengamos que los casos de responsabilidad indirecta son una genuina hipótesis de inobservancia de los deberes de protección ocasionado por los auxiliares que utilizan las partes en el cumplimiento.

a.- Presupuestos

Tradicionalmente cuando se analiza la responsabilidad contractual, se observa la problemática desde la figura de un acreedor y de un deudor ligados por un contrato previamente celebrado. Es decir, se trata de un esquema en principio sencillísimo, un vínculo personal y dos partes sujetas a él.

ss.; Diez-Picazo, Luis y Gullon, Antonio, Sistema de Derecho Civil II, 6a ed., Tecnos, Madrid, 1989, pp. 624 y ss.; JORDANO FRAGA, La responsabilidad del deudor por los auxiliares..." Ob. Cit.; JIMÉNEZ HORWITZ, La imputación del deudor..."Ob. Cit. 
No obstante, lo anterior no es más que un prejuicio antojadizo, impuesto más por la candidez y comodidad del paso de los años, que por un pensamiento crítico subyacente. Ya hemos revisado a propósito de la relación obligatoria moderna, que en esta, no existe un único vinculo jurídico, sino un conjunto de ellos, representando una visión orgánica y funcional tanto de la situación del crédito como de la deuda, alterando con ello las líneas tradicionales de la responsabilidad civil.

Como señala Jordano Fraga ${ }^{546}$ puede parecer a simple vista, que este tipo de responsabilidad sea un fenómeno anómalo o excepcional, que la regla o lo normal sea una responsabilidad directa o personal, es decir, una coincidencia entre sujeto responsable y autor material del daño que se indemniza.

No obstante, esto no se corresponde, ni a la realidad de las normas vigentes del ordenamiento civil, ni mucho menos a la realidad práctica de su aplicación. Desde un punto de vista normativo, la responsabilidad civil directa y la indirecta son dos fenómenos igualmente presentes en nuestro derecho vigente, dos fenómenos igualmente normales en él, que deben ser analizados, cada uno de ellos, con arreglos a sus propios presupuestos

No debe sorprendernos lo categórico de tales afirmaciones, pues, la noción de responsabilidad contractual indirecta ha estado presente desde siempre en la conciencia jurídica de los pueblos. Fíjese, en una cuestión tan general y trascendental en el derecho de civil como es el pago de las obligaciones, nadie se cuestiona que el

546 Jordano FragA, La responsabilidad del deudor..., Ob. Cit., p. 20. 
pago hecho por un auxiliar del deudor es válido, es decir, dicho pago realizado por el auxiliar constituye pago del deudor y no pago de tercero, con las consecuencias respectivas para el deudor tanto en el cumplimiento o incumplimiento de lo convenido.

Ya en el Derecho romano se no era ajena este tipo de responsabilidad, así en el Digesto a propósito del contrato de locatio conductio operis se disponía: "El que tomó en arriendo el transporte de una columna, si esta se rompió al retirarla, llevarla o dejarla en su sitio, ha de ser responsable de este riesgo si hubiese ocurrido con culpa del mismo o de aquellos que están a su servicio. ${ }^{5047}$

También, existieron casos de responsabilidad indirecta de ratio objetiva, así en los supuestos de custodia técnica, agrupados bajo la denominación de receptum, el naute, caupo, y stabularii respondían, aun sin culpa propia, de las culpa de sus siervos y colaboradores. ${ }^{548}$

Durante la Edad Media, pese a que no se encontraba estipulada en un estatuto, en el nivel de las corporaciones primó la regla de que el patrón de una bodega tenía que ser considerado responsable frente a sus clientes por los daños causados a éstos por obra de los aprendices que aquél tenía a su cargo, compréndanse en este campo, tanto la simple inejecución de la prestación como la ejecución defectuosa, que eran sancionadas mediante la imposición de severas multas a los dañadores. ${ }^{549}$

\footnotetext{
${ }^{547}$ D. 19, 2, 25, 27, Gayo: "Qui columnam transportandam conduxit, si ea, dumtollitur, aut portatur, aut reponitur, fracta sit, itai dpericulumpraestet, si qua ipsius eorumque, quórum opera uteretur, culpa acciderit."

${ }_{548}$ D. 4, 9, 1: "hoc edicto omni modo qui recepit tenetum etiamsi eius res periit vel damnum datum est, nisi, si quid damno fatali contingit."

${ }^{549}$ FerRaRA, Ob. Cit., p. 55.
} 
Posteriormente, con la aparición en Europa de los primeros cuerpos normativos de Derecho civil, como los códigos de Austria (1811) y de Sajonia, el Landrecht prusiano, la primera versión del Código de las Obligaciones suizo (1881), unido a la acentuación de una práctica jurisprudencial favorable, a la que no fueron ajenos los países del Common Law, la responsabilidad indirecta por incumplimiento de obligaciones terminó de vislumbrarse como un principio general. ${ }^{550}$

Ahora bien, respecto al factor de atribución de la responsabilidad contractual por hecho ajeno, como señala Jordano Fraga puede hacerse, tanto sobre la base de la culpa o bien sobre una base normativa objetiva. ${ }^{551}$

En el primer caso, la imputación del daño causado por otro se hace responsable sobre la base de la propia culpa o negligencia (responsabilidad "in vigilando", "in eligendo" o "in instruendo"). En el segundo caso, la valoración de la culpa implica un juicio de comportamiento o conducta, en relación a un parámetro objetivo de conducta diligente y no un juicio de intenciones o voluntades.

Nosotros creemos que el fenómeno de la responsabilidad civil indirecta se explica y fundamenta mejor desde la perspectiva objetiva, por cuanto, la imputación subjetiva resulta inadecuada a la realidad.

\footnotetext{
${ }^{550}$ FERRARA, Ob. Cit., p. 60.

551 JoRdANO FRAGA, La responsabilidad del deudor..., Ob. Cit., p. 29.
} 
Mantener la responsabilidad contractual por hecho ajeno dentro de los limites de la culpa del deudor, resulta total y absolutamente desproporcionado en lo que concierne a los legítimos intereses del acreedor que, a falta de la culpa del deudor, vería vulneradas sus expectativas de resarcimiento.

La solución culpabilística terminaría por crear, por tanto, un vacío en el sistema de responsabilidad contractual: el sujeto obligado no respondería del incumplimiento. ${ }^{552}$

Por el contrario, cuando la imputación jurídica del daño causado por otro, se hace al sujeto responsable objetivamente (deudor) sin el vehículo de la culpa, no hallamos ante una responsabilidad por otro más coherente, tanto en la causación del daño como desde la imputación jurídica del mismo.

Así la responsabilidad objetiva del responsable indirecto (sujeto obligado) se transforma en un mecanismo para asegurar la indemnización del dañado, que presupone la falta de responsabilidad personal (en términos de la culpa) del deudor (responsable indirecto), pudiendo este último recuperar la indemnización que pago al dañado, -ya que no hay culpa personal- de el causante material del daño (auxiliar), materializándose por la vía del regreso la responsabilidad personal (culpable) de su auxiliar. ${ }^{553}$

En síntesis, la intervención del auxiliar en el cumplimiento de la obligación no modifica las expectativas del acreedor en la

\footnotetext{
552 JIMÉNEZ HORWITZ, Ob. Cit., p. 85.

553 JORDANO FRAGA, La responsabilidad del deudor..., Ob. Cit., p. 29.
} 
responsabilidad del deudor, porque éste responde de la actuación de aquél en los mismos casos en los que respondería de la propia. Esta es, en resumidas cuentas, la principal virtualidad del carácter objetivo de la responsabilidad del deudor por el auxiliar. ${ }^{554}$

\section{b.- Breve referencia al Derecho civil chileno}

Como señala la escasa doctrina que se refiere a la materia en cuestión, ${ }^{555}$ el Código civil chileno no se refirió expresamente a la responsabilidad contractual indirecta como categoría general.

No obstante, en dicho cuerpo normativo, existen diversas disposiciones particulares que permiten construir una regla y un principio general respecto a la responsabilidad contractual por el hecho ajeno. ${ }^{556}$

\footnotetext{
554 JIMÉNEZ HORWITZ, Ob. Cit., p. 89.

${ }^{555}$ Sobre responsabilidad contractual por hecho ajeno en Chile véase, FUENZALIDA PUELMA, Sergio, "Los terceros en la responsabilidad contractual", en Revista de Derecho y Jurisprudencia № 57, 1960, primera parte, pp. 104-117.; CLARO SOLAR, Luis, Explicaciones de Derecho civil chileno y comparado, vol. V (delas obligaciones), Editorial Jurídica de Chile, Santiago, 1979, pp. 539 y ss.; ABELIUK MANASEVICH, Ob. Cit., tomo II, p. 140.; INFANTE CAFFI, Horacio, "El factor de atribución en la responsabilidad civil contractual por el hecho ajeno" en Revista de Derecho y Humanidades, № 7, 1999, pp. 191-198.; ZeLAYA, Pedro, "La responsabilidad civil por el hecho ajeno y el seguro" en Revista Chilena de Derecho, vol. 29, No 1, 2002, pp. 95-110,.; PIZARRO WILSON, Carlos, "Obligaciones y Responsabilidad Civil. Comentarios de Jurisprudencia" en Revista Chilena de Derecho Privado, №13, 2009, pp. 239-247.

${ }^{556}$ El artículo 1590, establecido a propósito del pago de una especie o cuerpo cierto, señala en su inciso $1^{\circ}$ que el acreedor debe recibir la especie debida en el estado en que se halle, " ... a menos que se haya deteriorado y que los deterioros provengan del hecho o culpa del deudor, o de las personas por quienes éstos es responsable ... ". Por su parte, en el inciso $3^{\circ}$ señala que: "Si el deterioro ha sobrevenido antes de constituirse el deudor en mora, pero no por hecho o culpa suya, sino de otra persona por quien no es responsable, es válido el pago de la cosa en el estado en que se encuentre ... ".; el artículo 1679: establecido en el titulo relativo a la extinción de la cosa debida cuando se trata de una especie o cuerpo cierto, dentro del Libro VI, señala que: "En el hecho o culpa del deudor se comprende el hecho o culpa de las personas por quienes fuere responsable".; Artículos 1925 y 1926:
} 
Esta regla general se concretiza -creemos- en el articulo 1679 del libro IV título XIX a propósito de la pérdida de la cosa que se debe, este precepto señala: "En el hecho o culpa del deudor se comprende el hecho o culpa de las personas por quienes fuere responsable."

Es en esta misma dirección, donde apunta la jurisprudencia nacional que se ha ocupado del tema, construyendo un principio general de responsabilidad contractual indirecta en base al artículo 1679 del Código Civil.

$$
\text { Así, se ha señalado por ejemplo por la Corte de Apelaciones de }
$$
Santiago: "quien asume una obligación, implica en su cumplimiento no

\footnotetext{
Establecen la responsabilidad del arrendador cuando por hechos suyos, o de sus agentes o dependientes, el anterior se coloca en imposibilidad de entregar la cosa, o se constituye en mora de entregar la cosa al arrendatario, respectivamente.; el artículo 1929: establece la responsabilidad del arrendador cuando el arrendatario es turbado en su goce de la cosa "por el arrendador, o por cualquiera persona a quien éste pueda vedado ... ".; El artículo 1941, establece la responsabilidad del arrendatario no sólo de su propia culpa, sino también por la " ... de su familia, huéspedes y dependientes". Como complemento.; EI articulo 1947 , inciso $3^{\circ}$, señala que si el arrendatario no prueba que los daños en la cosa no provinieron de su culpa, o de la de sus huéspedes, dependientes o subarrendatarios, será responsable por tales daños.; El artículo 2000, inciso $2^{\circ}$ : "el artífice será responsable de la pérdida de la materia con la que debla ejecutar la obra, cuando ella perece por su culpa o por culpa de las personas que le sirven".; El artículo 2003, regla $3^{\circ}$ : si un edificio perece o amenaza ruina en los cinco años siguiente a su entrega, por vicio de la construcción, o vicio del suelo que el empresario o sus empleados hayan debido conocer en razón de su oficio, o por vicio de los materiales, responderá el empresario., El artículo 2014: las obligaciones establecidas en el párrafo respectivo para el acarreador, " ... se entienden impuestas al empresario de transporte, como responsable de la idoneidad y buena conducta de las personas que emplea".; El artículo 2015, inciso final: la responsabilidad del acarreador por los daños y perjuicios en la persona o carga transportada se establece no solo por su propio hecho, sino por el de sus agentes o sirvientes.; El artículo 2242: en caso de depósito en un hotel o posada, el posadero responde de todo daño a los bienes del alojado y que provengan de su culpa o de la de sus dependientes, o incluso de los extraños que visitan la posada, y hasta de los hurtos y robos.; El artículo 2243: el posadero está obligado a dar seguridad de los efectos que el alojado conserva alrededor de si mismo y, por canco, es responsable del daño causado o del hurto o robo cometido por sus sirvientes, o por personas extrañas que no sean familiares o visitantes del alojado.
} 
solo su conducta y comportamiento, sino la conducta y comportamiento de las personas por quienes fuere responsable. ${ }^{" 557}$

En otro caso la misma Corte en la sentencia del 4 de julio de 2008, dispuso: "Que, en consecuencia, encontrándose vinculadas las partes por un contrato en virtud del cual la demandada se obligó voluntariamente a prestar un servicio de la naturaleza antes indicada, cobra aplicación la norma del artículo 1679 del Código Civil, en virtud del cual, en el hecho o culpa del deudor, se comprende el hecho o culpa de las personas por quienes fuere responsable. Ello implica, como ha sostenido la doctrina, que la responsabilidad del deudor absorbe o comprende, sin excepción, el hecho o culpa de la persona de quien se es responsable y por ende, el hecho o culpa del tercero debe considerarse como el hecho o culpa del deudor. ${ }^{, 558}$

En este orden de ideas, la Corte de Apelaciones de Concepción indicó: "Como la responsabilidad en el hecho o culpa del deudor, se comprende el hecho o culpa de las personas por quienes fuer responsable de acuerdo al artículo 1.679 del Código Civil, es responsable la demandada por el incumplimiento causado por el tercero." ${ }^{n 59}$

Finalmente, en el mismo sentido la Corte Suprema ha indicado: "Que es un principio general del derecho, recogido por nuestro ordenamiento jurídico en los artículos 1679, 2116 y 2135 del Código Civil, entre otros, que atendida la libertad del deudor para hacer

\footnotetext{
${ }^{557}$ Sentencia 28 de enero de 2008, Corte de Apelaciones de Santiago Rol № 3180-2003, considerando $12^{\circ}$ y $14^{\circ}$.

${ }^{558}$ Sentencia 4 de julio de 2008, Corte de Apelaciones de Santiago Rol No 7667-2004, considerando $4^{\circ}$.

${ }^{559}$ Corte de Apelaciones de Concepción Rol № 2143-2008, considerando $3^{\circ}$.
} 
participar a otros en el cumplimiento de sus obligaciones la responsabilidad derivada de la ejecución de un acto por un tercero no afectará a éste, ya que el negocio no lo gestiona para sí mismo sino por cuenta de otro, de suerte tal que será quien lo encarga el que soporte el riesgo como si fuera su propio hecho, pues es él quien aprovechará los beneficios. En definitiva, aquel que encomienda la realización de una tarea y, por consiguiente, se aprovechará de ésta, correlativamente, soportará las pérdidas del negocio emprendido y también los gastos, expensas y perjuicios que hubiere sufrido un tercero sin culpa y a causa o con ocasión de la referida ejecución."

Para nosotros, resulta evidente que la aplicación del artículo 1679 no se restringe a los casos de pérdida o extinción de la especie o cuerpo cierto, si no que la voluntad del legislador es darle plena aplicación general como se demostrará.

Viendo el asunto desde la perspectiva del elemento gramatical de interpretación, ${ }^{561}$ el artículo se refiere expresamente y en forma clara a la responsabilidad contractual del deudor por hecho ajeno: "En el hecho o culpa del deudor se comprende el hecho o culpa de las personas por quienes fuere responsable". Por lo que no cabe duda, a que el sentido y alcance del articulo es la responsabilidad contractual indirecta.

Respecto al análisis histórico del precepto, es necesario señalar que el artículo 1679 no figuraba en el proyecto original del Código

\footnotetext{
${ }^{560}$ Sentencia de 3 de julio de 2007, Corte Suprema Rol No 5939-2005, considerando $9^{\circ}$. ${ }^{561}$ Sobre el elemento gramatical véase, DuCCI CLARO, Carlos Interpretación jurídica, $3^{\mathrm{a}}$ ed., Santiago, Editorial Jurídica de Chile, 1997, pp. 100-125 y GUZMÁN BRITO, Alejandro, Las reglas del "Código Civil" de Chile sobre la interpretación de las leyes, Santiago, Editorial Lexis Nexis, 2007, pp. 77-81.
} 
civil, sino que fue incluido posteriormente en el proyecto inédito, en el libro IV título XIX a propósito de la pérdida de la cosa que se debe. ${ }^{562}$

Esta inclusión se debió -creemos- para salvar la ausencia de la responsabilidad contractual indirecta en el Código, originada por la enorme influencia francesa en materia de obligaciones. Teniendo presente la comisión, lo que ocurría con otros códigos decimonónicos fuentes del Código civil chileno, como el austríaco, prusiano y suizo, que si incluían expresamente la responsabilidad contractual por hecho ajeno. $^{563}$

Desde el punto de vista de interpretación lógica, la gran cantidad de disposiciones en que se contiene casos particulares de responsabilidad indirecta en el Código, ${ }^{564}$ nos hacen concluir que para alcanzar la concordancia, unidad conceptual y de criterio entre las diversas partes de la ley como dispone el artículo 22 inciso $1^{\circ}$, es imprescindible entender el artículo 1679 como principio general de responsabilidad contractual por el hecho ajeno.

Sin embargo, si aún no resulta suficiente para determinar el sentido y alcance del artículo 1679, a partir de la interpretación lógica de las normas contenidas en el Código civil, será necesario recurrir al elemento sistemático de interpretación de la ley. Recuérdese que este elemento, consagrado en el inciso $2^{\circ}$ del artículo 22 del Código civil, tiene por finalidad alcanzar la debida correspondencia de la ley interpretada con otras que versen sobre el mismo asunto, que

\footnotetext{
562 INFANTE CAFFI, Ob. Cit., p.196.

${ }^{563}$ Véase, Supra, Nota $n^{\circ} 550$.

${ }^{564}$ Véase, Supra, Nota $n^{\circ} 556$.
} 
permitirá evidenciar el espíritu general de la legislación en una materia determinada.

Así las cosas, la recepción de la responsabilidad contractual indirecta también se entiende aceptada por nuestro Derecho, a extramuros del Código civil. Una revisión de las normas contenidas en nuestra legislación revela que el artículo $79(2)^{565}$ de la Convención de Vienna sobre compraventa internacional de mercaderías, instaura un régimen de responsabilidad para el supuesto de incumplimiento del deudor -sea vendedor o comprador- que tiene su causa inmediata en el incumplimiento de un tercero a quien se le encargó el todo o parte de la ejecución del contrato. ${ }^{566}$ De lo que se sigue, que la voluntad del legislador es darle esa intensión al artículo 1679.

De todo lo expuesto precedentemente, se puede sostener que efectivamente es posible deducir un principio en el artículo 1679 que recoja la responsabilidad contractual indirecta como una categoría general en el sistema de responsabilidad civil chileno. Dicho precepto, contiene la ratio esencial del legislador en materia de responsabilidad contractual por hecho ajeno, no obstante su ubicación geográfica en el Código civil.

\footnotetext{
${ }^{565}$ Que es ley de la república desde 1991, esta Convención instaura un régimen de responsabilidad objetivado que se articula a partir del solo hecho del incumplimiento del contrato.

${ }^{566}$ Sobre la responsabilidad contractual indirecta en la Convención de Vienna sobre compraventa internacional de mercaderías véase, VIDAL OLIVARES, Álvaro, "La responsabilidad del deudor por incumplimiento de su tercero encargado en la compraventa internacional de mercaderías", en De la Maza Gazmuri, Iñigo (editor), Cuadernos de análisis jurídico. Colección derecho privado, III: Temas de contratos, Santiago, Ediciones Universidad Diego Portales, 2006, pp. 259-295.
} 
c.- Infracción del deber por el auxiliar del deudor

Como hemos venido afirmando, nuestra investigación se hacen cargo de una premisa elemental, que indica que el deudor esta obligado no solo a la realización de la prestación principal, sino también a todo lo necesario para que el acreedor consiga plenamente la satisfacción de su interés.

Sobre esta idea, se incardinan los deberes de protección, que buscan la salvaguardia de otros intereses de los contratantes distintos a los prestacionales en el sentido técnico, que pueden verse lesionados en la dinámica obligatoria (daños en su esfera personal o patrimonial).

Estos eventos lesivos tienen una estrecha conexión con el incumplimiento de la relación obligatoria, ofreciendo una tutela contractual a daños no prestacionales.

El principio de la responsabilidad del deudor por sus auxiliares, es una norma de imputación total o global, esto es, actúa de forma exhaustiva sobre todos y cada uno de los aspectos que integran el contenido de lo debido por le deudor.

Por ello, el ámbito de actuación de tal principio, no se limita solo a los deberes específicos del deudor de carácter estrictamente prestacional, sino que incluye, además, cuantos deberes imponga específicamente la obligación al deudor frente a su concreto acreedor, 
aunque estos resulten referidos a intereses diversos del genuinamente prestacional. ${ }^{567}$

De ello se deduce que para que la conducta del auxiliar tenga transcendencia a efectos de la responsabilidad contractual por el hecho ajeno debe significar la infracción de los deberes que integran el contenido del la obligación del deudor en su totalidad, bien se trate de la infracción de los deberes de prestación o bien se trate de los deberes de protección. ${ }^{568}$

El carácter total o exhaustivo del principio de la responsabilidad contractual del deudor por sus auxiliares implica que la misma realización del cumplimiento que el obligado debe como prudentes, atentas o cuidadosas, las sigue debiendo así, cuando en vez de cumplir o intervenir personalmente cumple o interviene utilizando un auxiliar. ${ }^{569}$ Por lo tanto, todo lo que se ha dicho en relación a la infracción de los deberes de protección, se predicará para la inobservancia del auxiliar utilizado por el deudor en su cumplimiento.

El deudor u obligado responderá contractualmente frente a su acreedor, en forma indirecta, por los daños causados a éste, en bienes jurídicos no objeto de la prestación debida, por el auxiliar de cumplimiento, siempre que esos mismos daños, de haber sido causados personalmente por el deudor u obligado, habrían generado también responsabilidad contractual, por entrañar infracción de la relación obligatoria que le vincula con su acreedor.

\footnotetext{
567 JoRdano Fraga, La responsabilidad del deudor..., Ob. Cit., p. 234.

568 JIMÉNEZ HORWITZ, Ob. Cit., p. 58.

569 JoRdAnO FragA, La responsabilidad...”, Ob. Cit., p. 237.
} 
De no ser así, en el ámbito de los deberes de protección, la utilización de auxiliares de cumplimiento por el deudor menoscaba la tutela contractual del acreedor, reduciendo la esfera de lo exigible, en relación sí actuara personalmente, y redirigiendo a la víctima en este caso el concreto acreedor para resarcir los daños ocasionados a un estatuto de responsabilidad aquiliana, desplazando así a otro la otrora responsabilidad contractual.

\section{II.- INFRACCIÓN DE LOS DEBERES DE PROTECCIÓN: Y SUS EFECTOS RESPECTO A TERCEROS}

\section{1.- EFECTOS PROTECTORES A TERCEROS}

La responsabilidad contractual del deudor, por los daños derivados de la inobservancia del deber de protección, no solo se afirma frente a su acreedor, sino que, en determinadas condiciones, también puede afirmarse frente a terceros de algún modo relacionados con el acreedor (por ejemplo, sus familiares, clientes, visitantes, empleados), por causa de cuya relación entran, de alguna forma, en contacto con la prestación del deudor o se sitúan en proximidad a la misma.

Es decir, la obligación al deudor en determinadas circunstancias, le puede imponer a éste un deber específico de protección, para evitar que, de la actividad de cumplimiento de su obligación, deriven daños en la esfera personal o patrimonial no solo 
del acreedor, sino también de otras personas (terceros) del entorno de éste.

Así, es posible sostener que el ámbito de los deberes de protección, no solo se verifica entre las partes de la relación obligatoria, sino también como se verá, respectos de terceros.

La teoría de la relatividad del contrato, que usualmente es justa y eficiente, resulta a veces contraria a las exigencias de justicia. Al fundamento "moral" de la teoría puede oponerse otro principio que tiene el mismo carácter: a veces no es equitativo que una persona deje de responder frente a terceros escudándose en el hecho de que no es parte en el contrato. ${ }^{570}$

Un ejemplo de ello lo constituye la doctrina alemana se ha elaborado una categoría nueva de contratos, ampliamente admitida por los tribunales, los llamados contratos con efecto protector para terceros (Vertrag mit Schutzwirkung für Dritter). ${ }^{571}$ En estos se reconoce la eficacia directa y propia entre las partes de un tercero

\footnotetext{
${ }^{570}$ AMAT LLARI, Ma Eulalia, "La teoría de la relatividad del contrato y sus excepciones" en Estudios jurídicos en homenaje al profesor Luis Díez-Picazo, t. II., Derecho de obligaciones, Thomson-Civitas, Madrid, 2003, pp.1285-1286.

${ }^{571}$ La jurisprudencia del Rechtsgericht (RG) tuvo pronto en cuenta esta realidad, y otorgó al tercero perjudicado, en aplicación del $\S 328$ del BGB, una pretensión de indemnización de daños y perjuicios contractual en una constelación de casos parecidos a los expuestos. La jurisprudencia se ha basado siempre en la interpretación, especialmente integradora de contrato ( $\$ 157 \mathrm{BGB}$ ). Es concluido tácitamente un contrato a favor de los terceros en cuya protección confía el acreedor como en la suya propia (familiares, criados). La posición del RG fue seguida y ampliada por su continuador el Bundesgerischtsof (BGH, máximo tribunal de la Republica Federal Alemana) afirmando la existencia de deberes de protección a favor de terceros en virtud de una interpretación integradora del contrato. Véase, CABANILLAS SÁNCHEZ, Antonio, "El contrato con efectos protectores para terceros en el Derecho alemán", en Estudios jurídicos en homenaje al profesor Luis Díez-Picazo, t. II., Derecho de obligaciones, Thomson-Civitas, Madrid, 2003, pp.1491-1523.
} 
cualificado por las relaciones de familia o laborales con el otro contratante. ${ }^{572}$

Tales contratos se fundan bajo la base, de que los riesgos que se conectan a la posibilidad de la injerencia que deriva del cumplimiento del deber de prestación que resulta de una relación obligatoria contractual, están sujetos no solo las partes contratantes sino también terceros que están en contacto con la conducta de prestación de la otra parte y por ello están expuestos de la misma manera que el propio acreedor a los riesgos que derivan de la relación obligatoria y en cuya protección el acreedor está tan interesado como si se tratase de su protección personal. ${ }^{573}$

Más allá de las eventuales soluciones concretas del derecho comparado, es evidente que la ampliación de la protección a terceras personas, es fruto de la integración del contrato por la buena fe, ya que, el cuidado, la cautela o la atención en la actividad del cumplimiento, no solo se debe respecto las partes, sino que lógicamente de otras personas que se relacionan con estas en su entorno íntimo o directo (familiares, dependientes)

Sin perjuicio de lo señalado, para poder comprender esta protección a terceros, es preciso examinar la teoría de la relatividad de los contratos, tanto sus consecuencias como sus atenuaciones y así construir una base dogmática sólida para nuestras posteriores reflexiones.

\footnotetext{
572 García Amigo, Manuel, Teoría general de las obligaciones y contratos, Lecciones de Derecho civil II. MacGraw-Hill, Madrid, 1995, pp. 376-377.

${ }^{573}$ CABANILLAS SÁNCHEZ, "El contrato con efectos protectores... Ob. Cit., p. 1492.
} 
a.- La teoría de la relatividad del contrato

El Código civil chileno, no consagra una norma explícita en relación al efecto relativo de los contratos, como su análogo francés. ${ }^{574}$

No obstante, se ha entendido implícitamente esta noción, ${ }^{575}$ en el artículo 1545, que consagra la fuerza obligatoria del contrato: "Los contratos válidamente celebrados son una ley para las partes y no pueden ser invalidados sino por el consentimiento mutuo o por causa legales."

La relatividad del contrato consiste en restringir el efecto obligatorio sólo a aquellos sujetos de derecho que concurrieron con su voluntad a celebrar el contrato, es decir, el contrato no beneficia ni perjudica a terceros que no participaron en su formación.

El efecto relativo de los contratos es uno de los cimientos fundamentales por el cual se erige el edificio del Derecho de los contratos, su origen indefectiblemente proviene del mundo romano, ${ }^{576}$

\footnotetext{
${ }^{574}$ Artículo 1165: "Les conventions n'ont dèffect qu'entre les parties contractantes; elles ne nuisent point au tiers, et elles ne lui profitent que dans le cas prévu par l'article 1121"; "Los contratos sólo producen efecto entre las partes contratantes. No perjudican a tercero ni le aprovechan, sino en el caso previsto en el artículo 1121."

${ }^{575}$ CLARO SOLAR, Luís, Explicaciones de derecho civil, Ob. Cit, t. XI, p. 653.; también en LÓPEZ SANTA MARÍA, Ob. Cit., p. 285.

${ }^{576}$ En el Derecho romano se mantuvo una concepción unívoca del principio de la relatividad que expresa la máxima "res inter alios acta aliis nec nocere nec prodesse potest". Este principio fue expresión de la personalidad del contrato, de la necesidad de la voluntad de las partes para obligarse, de la exclusión de los que no han contribuido a formar parte del pacto, en suma del limite subjetivo del vínculo obligatorio. Este principio en el mundo romano presentaba dos vertientes, por un lado, fue fruto de la concepción de la obligación romana
} 
respondiendo a una concepción formal y personalista del derecho, que fue recuperada por los interpretes y más tarde retomada por Domat, quien en la reelaboración de la idea del contrato, lo justificó sobre la base de una concepción voluntarista del acto jurídico. ${ }^{577} \mathrm{De}$ esta manera, se plasmó en la letra del precepto del artículo 1165 del Code, la cierta imposibilidad de que un tercero exija a una de las partes del contrato el cumplimiento de la prestación pactada frente a otra, ya que, no media entre ellos relación contractual alguna. ${ }^{578}$

De lo que se sigue que la teoría de la relatividad del contrato corresponden a las mismas exigencias morales de carácter filosófico del modelo contractual propio de la codificación: "nadie puede ser obligado a responder por aquello a lo que no se obligó". En este sentido, el contrato fruto de la voluntad de las partes justifica que solo éstas pueden resultar vinculadas $\mathrm{y}$, en definitiva, compelidas a cumplir las obligaciones que genera el contrato. Desde una óptica inversa, los terceros ajenos al contrato, que no concurrieron con su voluntad a la celebración el mismo, son extranjeros a sus efectos.

Toda esta teoría reposa en el dogma de la autonomía de la voluntad o autonomía privada, no obstante, dicho dogma en la actualidad como principio rector del Derecho contractual está en

\footnotetext{
al considerarse como un vínculo jurídico que necesariamente legaba a dos personas $\mathrm{y}$, por otro lado, era una necesidad de la exigencia de la voluntad humana para obligarse, de tal forma, que la voluntad y la obligación se convierten en una serie de causa y efecto, para que exista obligación debe haber voluntad y, sin voluntad no hay obligación, no cabe, entonces, estipular por otro. Esta personalidad del contrato se manifiesta con especial énfasis en el Derecho clásico, que ni admite la representación, ni la estipulación para otro, y se modera ya con el Derecho pretorio, dado cabida a aquella y derivando ciertos efectos para tercero de forma muy limitada. Véase, RODRíguez GONZÁLEZ, José, El principio de la relatividad de los contratos en el Derecho español, Colex, Madrid, 2000, p. 24.

${ }^{577}$ GHESTIN, Jacques, Traité de Droit Civil, Les obligations, les effets du contrat, París, 1992, pp. 541-542.

${ }^{578}$ AMAT LLARI, Ob. Cit., p. 1281.
} 
franco retroceso. Siguiendo a Pizarro Wilson, ${ }^{579}$ en Chile suele considerar que la fuerza obligatoria del contrato es heredera de la autonomía de la voluntad, la cual encuentra su justificación en el aforismo "pacta sum servanda." Esta afirmación resulta discutible tanto desde el punto de vista histórico como de la perspectiva de la evolución del Derecho de contratos.

Una somero revisión histórico de la fuentes, evidencia que la idea según la cual la autonomía de la voluntad constituye un principio fundamental de la codificación, que a su vez, explicaría la fuerza obligatoria del contrato se basa en un error de la interpretación de la doctrina francesa de finales del siglo XIX.

Para el codificador francés la fuerza obligatoria del contrato expresada en el articulo 1134 del Code, tiene como fundamento la moral y la equidad, lo que exige el respeto de la palabra empeñada, así queda evidenciado en el pensamiento de Domat. ${ }^{580}$ En los tempranos comentarios efectuados por la doctrina al Code, no se utilizó la expresión autonomía de la voluntad, es más, en Francia solo se comenzó a utilizar recién en la década de 1830 la autonomía vinculada a la idea del contrato.

En Chile, la expresión "autonomía de la voluntad o autonomía privada" solo empieza a utilizarse a principios del siglo XX. Es

\footnotetext{
${ }^{579}$ PIZARRO WILSON, Carlos, "El efecto relativo de los contratos: partes y terceros" en el Código Civil de Chile (1855-20105), trabajos expuestos en el congreso internacional para conmemorar su promulgación, Lexis Nexis, Santiago, 2007, pp. 551 y ss.

${ }^{580}$ En él influyen las enseñanzas del racionalismo cartesiano, y la experiencia practica del magistrado, la profunda formación romanista y su rígido jansenismo moral. En su obra (Les lois civiles, Livre I, tít. I, secc. 2 y 3) El contrato obliga por que es justo, de ahí la fuerza obligatoria del contrato (secc. 2 VII) utilizada y consagrada en el artículo 1134 del Code. Véase, GonZÁlez Delgado José, Responsa lurisperitorum Digesta, vol. V, Universidad de Salamanca, 2004, pp. 29-30.
} 
recomendable dice el autor, no confundir la formación del contrato con la obligatoriedad del mismo, parece más ajustado considerar la regla prevista en el artículo 1545 del Código civil chileno como una disposición con contenido neutro. Esta regla no señala que el contrato es obligatorio por que las partes lo han querido, solo se limita a indicar que el contrato legalmente formado es una ley para las partes ${ }^{581}$

Ahora, en relación a la evolución experimentada por el Derecho de contratos, la idea de fondo de la libertad contractual y primacía de la voluntarismo han cedido considerable terrenos. Piénsese, por ejemplo en los contratos de adhesión, forzosos o dirigidos, de fluido tráfico en la contratación moderna. Por lo que resulta, a lo menos meritorio, poner en duda la justificación voluntarista del contrato.

Con todo, como subraya López Santa María, en el Derecho contemporáneo se ha marcado cierta tendencia en declinar los postulados del voluntarismo en los contratos. Comprobándose por una parte la proliferación de excepciones al efecto relativo, el surgimiento de casos en que un contrato crea derechos y obligaciones para un penitus extranei o tercero absoluto. Y por otra parte, decanta en la actualidad el llamado efecto expansivo o absoluto de los contratos, conforme al cual indirectamente, los contratos pueden beneficiar o perjudicar a muchas personas que no revisten el carácter de partes. ${ }^{582}$

b.- Efecto absoluto del contrato

\footnotetext{
${ }^{581}$ PIZARRO WILSON, "El efecto relativo de..." Ob. Cit., p. 252.

582 LÓPEZ SANTA MARÍA, Ob. Cit., p. 287.
} 
El efecto absoluto o expansivo de los contratos, ${ }^{583}$ corresponde ciertamente a una atenuación o inflexión de la teoría de la relatividad del contrato. De esta manera, se hace frente al dogma de la autonomía de la voluntad, como principio exclusivo de la contratación.

Con Savatier ${ }^{584}$ en la década de 1930 en Francia, comienza agudamente a criticarse los postulados de la teoría de la relatividad de los contratos. Este autor, niega categóricamente que el principio de relatividad de contrato, sea producto o se adecue a la realidad jurídica subyacente, sino por el contrario es fruto de la concepción individualista y simplista del derecho de obligaciones que parte de la idea básica de que los asuntos de cada uno conciernen únicamente al que los gestionan, y que la sociedad y los terceros al acto no tiene nada que decir.

La evolución actual del Derecho patrimonial, por el contrario afirma Savatier, tiende cada vez más a permitir la idea de que los asuntos de cada uno tienen una vertiente individual y otra social, las relaciones jurídicas y las obligaciones conciernen no solamente al individuo de decide, sino también, en ciertos aspectos, a la sociedad $y$, por consiguiente, a los terceros. ${ }^{585}$

\footnotetext{
${ }^{583}$ Para el efecto absoluto o expansivo de los contratos en la doctrina chilena, véase, DOMíngUEZ, Ramón, "Los terceros y el contrato" en Revista de Derecho Universidad de Concepción, núm. 174, LI, jul.-dic., 1983, pp. 151-165.; LóPEZ SANTA MARÍA, Ob. Cit., pp. 308 y ss.; VIDAL OLIVARES, Álvaro, "El efecto absoluto de los contratos" en Revista Chilena de Derecho, núm. 6, 2006, pp. 51-85.; PIZARRO WILSON, "El efecto relativo... Ob. Cit., pp. 251 y ss.; Henríquez HeRreRA, lan, "Para una delimitación del efecto expansivo de los contratos" en Revista Chilena de Derecho, vol. 39 № 2, 2012, p. 513-522.

584 SAVATIER, René, "Le prétendu principie de l'effet relatif des contrats" en Reveu Trimestrielle de Droit Civil, 1934, pp. 524 y ss.

${ }^{585}$ SAVATIER, Ob. Cit., pp. 524-525
} 
La eficacia contractual no se agota, en lo derechos y obligaciones que crea o en la regulación de la conducta de las partes que concurren con su voluntad a celebrarlo. El contrato, introduce un cambio en la realidad jurídica, constituyendo un fenómeno que se inserta en dicha realidad y como tal no puede ser desconocido por los terceros. El contrato, proyecta su eficacia más allá de la relación contractual a la que da origen, alcanzando a terceros extraños a su celebración, ya no como acto jurídico, sino como hecho que incide en la realidad jurídica. ${ }^{586}$

Como subraya Diez-Picazo: "El principio de relatividad de la eficacia del contrato merece sin embargo alguna puntualización, pues lo cierto es que el contrato, una vez que ha sido realizado, penetra, puede decirse, en el mundo de la realidad jurídica y se instala en él." ${ }^{587}$

El contrato, por lo tanto es un hecho social, es decir, un hecho que se introduce en una realidad jurídica determinada y que como tal es oponible a terceros, quienes no pueden ignorarle, pudiendo beneficiarse del mismo en algunos casos y perjudicarse en otros. Lo anterior, se traduce en una doble consecuencia, primero los terceros deben reconocer los derechos emanados del contrato, y segundo, los terceros ante el incumplimiento contractual pueden invocar ese incumplimiento ante las partes si han padecido un perjuicio. ${ }^{588}$

No es correcto entonces, indicar que los contratos solo producen efectos entre las partes, al contario el contrato por esencia

\footnotetext{
${ }^{586}$ VIDAL OLIVARES, "El efecto absoluto... Ob. Cit., p. 54.

587 Diez-PICAZO, Fundamentos... Ob. Cit., t. I., p. 527.

588 PIZARRO WILSON, "El efecto relativo... Ob. Cit., p. 254.
} 
es oponible a todos, subraya el profesor Domínguez Águila, porque nadie puede desconocer el contrato convenido entre otros, ni puede, por lo mismo, impedir, ni privar, ni discutir a las partes los derechos y obligaciones que provienen del contrato. Lo que ocurre, es que un contrato no es únicamente una cuestión de creación de norma legal y de imperio de la voluntad, es mucho más que eso, se inscribe en un contexto social y, por lo mismo, es también un hecho social. ${ }^{589}$

Por su parte, sostiene López Santa María, que en alguna medida en cuanto el contrato es un hecho que como tal existe para todos, en sus efectos reflejos puede alcanzar a terceros absolutos, no para crear directamente un derecho o una obligación en el patrimonio de ellos, sino en cuanto es factible traerlo a colación o formular una pretensión fundada en el contrato ajeno. ${ }^{590}$

En este orden de cosas, a diferencia de lo que ocurre con las excepciones del efecto relativo, ${ }^{591}$ que requieren una disposición legal, el efecto absoluto constituye un efecto normal de todo contrato.

De tal forma que la oponibilidad del contrato a terceros resulta ser la regla general, toda vez, que cuando la ley prevé expresamente la regla de la oponibilidad con relación a un contrato, esta reconociendo implícitamente a contrario sensu la regla de oponibilidad, que se traduce en que siempre existe la posibilidad que cualquiera de las partes, o ambas, funden en el contrato una pretensión que afecte a un tercero, quien no podrá oponerse o

\footnotetext{
${ }^{589}$ Domínguez ÁGUILA, Ob. Cit., pp.153-154

590 LÓPEZ SANTA MARÍA, Ob. Cit., p. 308.

591 Siguiendo a López Santa María, las excepciones son; estipulación a favor de otro y la promesa de hecho ajeno. Véase, LÓPEZ SANTA MARÍA, Ob. Cit., pp. 303 y ss.
} 
desconocerlo, amparándose en el efecto relativo de los contratos. El legislador se ve en la necesidad de establecer expresamente la sanción de inoponibilidad precisamente porque la regla es la oponibilidad del contrato a terceros. ${ }^{592}$

A igual conclusión llega la doctrina española. ${ }^{593}$ Lo cierto es, que la oponibilidad es la consecuencia normal de la consideración de contrato como hecho jurídico, por eso, en principio, nada impide que el contrato sea oponible a terceros. Prueba de ello, es que el ordenamiento, recoge la inoponibilidad en determinados casos, como una medida protectora de determinados terceros, lo que indica claramente, que si necesitan ser protegidos por la norma a fin de evitar la oponibilidad, es que la misma se predica de manera general de todo acto jurídico. ${ }^{594}$

\section{2.- EFECTO EXPANSIVO DEL CONTRATO Y DAÑOS A TERCEROS}

El incumplimiento contractual, puede ser fuente de riesgo y daño a terceros ajenos al vínculo contractual, y por ende, éste puede -

\footnotetext{
${ }^{592}$ VIDAL OLIVARES, "El efecto absoluto... Ob. Cit., p. 63.

${ }^{593}$ Sobre este parecer expone Diez-Picazo: "Defectuosamente enunciada por la doctrina la categoría de la oponibilidad ha sido analizada casi únicamente en su aspecto negativo (inoponibilidad). La inoponibilidad se contempla como consecuencia de la ineficacia y también como una consecuencia de la falta de publicidad de un negocio eficaz. Mas la idea de la inoponibilidad presupone la de la "oponibilidad," que no significa eficacia directa o refleja del negocio en a esfera de terceros, sino simplemente posibilidad de que las partes funden eficazmente en su propio negocio una pretensión dirigida contra el tercero. Frente a un tercero que se presenta como adquirente de una cosa, las partes oponen un negocio de transmisión anterior y preferente. La oponibilidad así entendida es un efecto normal del negocio jurídico siempre que las partes hayan cumplido la carga de dar a su negocio la publicidad y el carácter fehaciente que el ordenamiento jurídico exige." Véase, DiEZ-PICAZO, Fundamentos... Ob. Cit., t. I., p. 531.

${ }^{594}$ RODRÍGUEZ GONZÁLEZ, El principio de la relatividad... Ob. Cit., p. 161.
} 
como veremos- ser invocado por el tercero perjudicado, como causa de su daño.

Algún sector de la doctrina moderna ${ }^{595}$ ha denominado este fenómeno dentro de la categoría de los llamados "contratos en daño de terceros." Se alude con ella, a aquellas hipótesis en que, al celebrar un contrato, y precisamente a causa de la celebración de este, los contratantes ocasionan un daño a una tercera persona.

Si el contrato es "lex inter partes", no resulta coherente que esa "lex privata" pueda afectar lesivamente a quien no participó en su formación. En este sentido, el tercero a un contrato no tiene la necesidad de soportar que éste le provoque un daño.

Bajo este contexto, las partes contratantes, deben cuidar de no inmiscuirse en la esfera ajena: la lex privata lo es inter partes, no pudiendo afectar a terceras personas. Sobre este particular señala López Santa María, reiteradamente tribunales extranjeros han admitido la inejecución o el incumplimiento de un contrato por una de las partes, sea invocado contra ella por un tercero como base fundamental de una demanda indemnizatoria den sede extracontractual. ${ }^{596}$

Así las cosas, podemos afirmar concretamente, que terceros ajenos al vínculo contractual puedan resultar lesionados producto de un incumplimiento contractual. Sobre este tópico, nos interesa abocarnos al especial caso de las víctimas por daño reflejo o por

\footnotetext{
595 Diez-PICAZO, Fundamentos... Ob. Cit., t. I., p. 550.

596 LÓPEZ SANTA MARÍA, Ob. Cit., p. 313.; También en HenRíqueZ HerRera, Ob. Cit., p.517
} 
rebote, que creemos tiene una mayor relación material con nuestro objeto de estudio, por cuanto, ocasionado un daño por infracción del deber de protección en la relación obligacional, terceros que tiene una especial vínculo o dependencia con las partes, pueden verse desfavorecidos y lesionados por los efectos expansivos o absoluto del contrato, los cuales para resarcir tales daños invocaran la infracción del deber de protección ante las partes como constitutivo de su régimen de responsabilidad civil.

a.- Víctimas por daño por repercusión, reflejo o rebote

Frecuentemente, con la ocurrencia de un ilícito civil se generan perjuicios directos a los sujetos personalmente afectados con el hecho dañoso, pero también se producen a propósito del mismo hecho ilícito inicial, perjuicios patrimoniales y extrapatrimoniales a sujetos que mantienen alguna vinculación o lazo con las víctimas directa del daño.

De un lado se encuentra la persona directa e inicialmente dañada, la que sufre el daño en la esfera de sus bienes o derechos, y por otro lado esta la persona indirectamente perjudicada, no en su patrimonio, cuerpo o salud, sino en la esfera pecuniaria o en la moral o en ambas respectivamente. ${ }^{597} \mathrm{~A}$ estas personas la doctrina denomina víctimas por daño reflejo, rebote, o por repercusión. ${ }^{598-599}$

\footnotetext{
${ }^{597}$ Vicente Domingo, Elena en (Coord.) Reglero Campos, Fernando, Busto Lago, José, Tratado de Responsabilidad Civil t. I., $5^{\mathrm{a}}$ ed., Thomson Reuters Aranzadi, Navarra, 2014, pp. 398-394.

${ }^{598}$ Es la doctrina francesa la que mayores contribuciones ha realizado en relación a la configuración y delimitación de la categoría de daños reflejos o por rebote en este sentido LAMBERT FAIVRE, Yvonne, De la responsabilitité encourue envers les personnes autres que
} 
No debemos confundir este daño, con aquel que deriva de la víctima directa que también pueda ser reclamado por las victimas indirectas, por medio de la transmisibilidad de las acción de indemnización.

La peculiaridad ${ }^{600}$ de este hecho dañoso radica en que el perjuicio causado a la víctima inicial o directa se ve proyectado o repercute de forma mediata en una persona distinta, ya sea un familiar o tercero, causándole un daño de naturaleza moral o patrimonial. Esta peculiaridad, se sigue tanto, por surgir con ocasión de un daño ajeno, como también por sufrirlos única y exclusivamente, otra persona, distinta de aquella, con la que se tiene unos vínculos, estrechos y actuales.

\footnotetext{
la victime initiale: le problème dit du dommage par ricochet, Th., Lyon, 1959.; VINEY, Genevieve, "Le dommage inditect ou par ricochet en Droit français" en Développements récents du Droit de la responsabilité civile, Zürich, 1991, pp. 249 y ss.; BOURRIÉ-QUENILLET, Martine, "Droit du dommage corporel et prix de la vie humaine" JCP $N^{\circ} 21,2004$, Doct., pp.136 y ss.; En España, VICENTE DOMINGO, Elena, Los daños corporales: Tipología y valoración, Bosch, Barcelona 1994, pp. 211 y ss.; VATTIER FUENZALIDA, Carlos, "Los daños de familiares y terceros por la muerte o lesiones de una persona" en Centenario del Código Civil, II, Madrid, 1990, pp. 2069 y ss.; MOREno MARTíneZ, José, Daños indirectos en familiares y terceros por causa de lesiones, Cuadernos Aranzadi Civil, Navarra, 2013.; En Italia, la doctrina opta por la denominación de daños reflejos, VISINTINI, Giovanna, I fatti illeciti. Ingiustizia del danno, Ed. Padova, Cedam, 1996, reimpr. 2004, pp. 116 y ss.; FACCI, Giovanni, II nuovi danni nella famiglia che cambia. Nuovi percorsi di Diritto di Famiglia, 2009, pp.251 y ss.; FAROLFI, F., "L'estensione del danno morale riflesso oltre i casi di morte e di lesioni personali gravi," Nota di commento, Cass. sez III, 21 settembre 2007, en Nuova giur., civ., 2008, núm. 3, pp. 313 y ss.; En Chile véase al respecto, BARROS BOURIE, Enrique, Tratado de responsabilidad extracontractual Editorial Jurídica, Santiago, 2010, pp. 354 y ss.; AlessandRI RodRíGuez, Arturo, De la responsabilidad extracontractual ..., Ob. Cit., pp. 170-180-329; Rodríguez GREZ, Pablo, Responsabilidad extracontractual, editorial Jurídica de Chile, Santiago, 1999, p. 360.; ElORRIAGA DE BONIS, Fabián, "Del daño por repercusión o rebote", en Revista Chilena de Derecho, vol. 26 № 2, 1999, pp. 369-398.

${ }_{599}$ Para algunos autores, el origen del daño por rebote como categoría, puede encontrase en el viejo debate de los Glosadores que discutían acerca de la legitimación de los herederos y familiares del hombre libre fallecido, para reclamar los daños causados con su muerte. Véase, IGLESIAS, Juan, Derecho romano, Instituciones de Derecho privado II, 1953, p. 124.

VAtTIER Fuenzalida, Ob. Cit., pp. 2069.
} 
Por su origen, es un daño causalmente dependiente del daño inicial, con importantes consecuencias prácticas en el terreno de la prueba y de las excepciones que ello implica, sin embrago es completamente independiente en su certeza y realidad. ${ }^{601}$ El daño por repercusión o rebote, podemos definirlo siguiendo a Elorriaga como el que nace a consecuencia del perjuicio provocado a una víctima inicial de un hecho ilícito, y que afecta a personas diversas del sujeto inmediatamente perjudicado. ${ }^{602}$

b.- Determinación

En relación con esta clase de víctimas, se presenta la cuestión de determinar en principio quienes son las personas legitimadas para reclamar el daño por rebote causado, toda vez que, la cadena de perjudicados a consecuencia de un hecho dañoso podría llegar a ser verdaderamente insospechada.

Al respecto, tratándose de los daños en las cosas, la regla parece pacífica, por cuanto, de acuerdo al articulo 2315 del Código Civil chileno, puede pedir la indemnización no sólo el que es dueño o poseedor de la cosa sino que también el usufructuario, el habitador o el usuario si el daño irroga perjuicio a su derecho.

Muy distinto es el caso que se presenta respecto de los daños sufridos en la persona de la víctima inicial, por cuanto, es en estos

\footnotetext{
${ }^{601}$ ViCEnTE DOMINGo, Tratado de Responsabilidad... Ob. Cit. p. 394.

${ }^{602}$ EloRRIAGA De Bonis, Ob. Cit., p. 370.
} 
casos, cuando resulta bastante problemático determinar quienes son, dentro del amplio abanico de sujetos, las personas que están legalmente investidas de la titularidad para pretender ser indemnizadas por el autor del daño en calidad de víctimas por repercusión. ${ }^{603}$

En Chile, de la simple lectura de la de las normas que contienen la clausula general de responsabilidad extracontractual, (artículos 2314 y 2329) se deduce que cualquier persona aún víctimas secundarias o indirectas, que han sufrido un perjuicio derivado del hecho ilícito, tienen derecho a ser indemnizadas.

Luego dado lo anterior, para poder determinar quienes son titulares de la acción de responsabilidad por daño reflejo, será necesario revisar por separado el daño patrimonial del extrapatrimonial, para así tener una mejor óptica de las peculiaridades y criterios que nos servirán para la discriminación oportuna de esta clase de víctimas.

\footnotetext{
${ }^{603}$ En algunos ordenamientos han optado por declarar expresamente el derecho de las víctimas por repercusión a ser indemnizadas por parte del agresor. Así en el BGB en los $\S$ 844 y 845 , se contempla el daño sufrido por los parientes o terceros, como consecuencia de la pérdida del derecho de alimentos o la interrupción de la prestación de servicios. También en el Código Penal español artículo 104 se señala que la indemnización de perjuicios materiales y morales comprenderá no solo los que hubieran causado al agraviado, sino también los que se hubiesen irrogado, por razón del delito a su familia o aun tercero. En el Código Federal de las Obligaciones de Suiza dispone el artículo 45 que en caso de muerte de un hombre, otras personas han sido privadas de su sustento, tienen derecho a ser indemnizadas en esa parte. El Código Civil Argentino, en su artículo 1079 dispone que la obligación de reparar el daño causado por el delito existe, no solo respecto de aquel a quien el delito ha damnificado directamente, sino respecto de toda persona que por él hubiese sufrido, aunque de manera indirecta.
} 


\section{i.- Daño patrimonial}

En el plano patrimonial el daño se plantea cuando una persona lograba u obtenía ciertos recursos o fuentes de ingreso de la víctima directa, y a consecuencia de su muerte o incapacidad, la víctima por rebote resulta afectada materialmente. Respecto de esta hipótesis, es necesario distinguir, a su vez, si la victima directa fallece o no. ${ }^{604}$

Podría pensarse en principio que esto debería quedar limitado exclusivamente al caso en el que la víctima inicial fallece, por cuanto, si solo ha recibido lesiones que provocan su incapacidad, la indemnización que en teoría se le conceda a la víctima inicial debería ser suficiente como para cubrir adicionalmente las necesidades de las personas que de ella dependen.

No obstante, lo cierto es que pueden plantearse casos, en los que la incapacidad de la víctima inicial y la indemnización respectiva no coincida entera o directamente con el daño material sufrido por otras personas a ella vinculadas. ${ }^{605}$

Algunos criterios para determinar la legitimación de las personas indemnizable por el daño reflejo, se agrupan entre las víctimas que tenían derecho a reclamar alimentos, las víctimas dependientes que no tenían derecho a alimentos siempre que se compruebe la necesidad y periodicidad continúa, ${ }^{606}$ los relacionados profesionalmente o laboralmente con la víctima inicial o directa, en

${ }^{604}$ BARRos BourIE, Ob. Cit., pp. 346-347.

605 ElORRIAGA DE BONIS, Ob. Cit., p. 374.

${ }^{606}$ MAZEAUD, y TUNC, Ob. Cit., pp. 395-401 
estos casos la posición es muchísimo más cauta que en los otros casos, ya que la idea que una indemnización de perjuicios sea procedente teóricamente en estos casos, es que la víctima directa del daño sea una persona verdaderamente insustituible en sus funciones profesionales. ${ }^{607}$

En lo referente a las víctimas que tenían derecho a pedir alimentos, ${ }^{608}$ es generalmente aceptado por la doctrina $y$ jurisprudencia comparada, que la muerte o lesión daña o perjudica a las personas que revisten el carácter de alimentarios de la víctima directa, el daño se considera cierto, perjudicando concretamente un interés legítimo de la víctima por rebote. ${ }^{609}$

Se plantea respecto de este criterio, la duda si es necesario que estas personas hayan efectivamente percibido los alimentos antes de la muerte o inhabilidad de la víctima inicial o por el contrario no cabría exigirle al perjudicado que la víctima lo hubiese socorrido en vida o antes de la inhabilitación.

Nosotros creemos que no es necesario que los alimentos hubiesen sido efectivamente entregados, toda vez que, se trata de un titular de un derecho legítimo, cuyo crédito se ve desvanecido por la muerte o inhabilidad del alimentante, ocasionando en la víctima por repercusión un perjuicio es real y cierto. ${ }^{610}$

\footnotetext{
${ }^{607}$ VINEY Genevieve y MARKESINIS Basil, La réparation du dommage corporel: Essai de comparaison des droits anglais et français, Paris, 1985, pp. 84-85.

${ }^{608}$ En Chile el artículo 321 del Código civil, concede alimentos al cónyuge, los descendientes, los ascendientes, a los hermanos, al donatario que hizo una donación cuantiosa si no hubiese sido rescindida o revocada.

${ }^{609}$ MAZEAUD, y TUNC, Ob. Cit., pp. 390 y ss.

${ }^{610}$ De CupIS, Ob. Cit., pp. 650 y ss.; También en MAZEAUd, y Tunc, Ob. Cit., p. 392.
} 
En relación a su avaluación, señala Barros Bourie ${ }^{611}$ el daño emergente no presenta más interrogantes que la causalidad típica de estos daños, es decir, si las perdidas o gastos pueden ser objetivamente atribuidos a las lesiones o a la muerte del la víctima directa. En cuanto a la valuación del lucro cesante reflejo, si se presentan complejidades a tener en presente.

Así la incertidumbre relativa a la evolución de los ingresos futuros de la víctima directa o si esta hubiera continuado la ayuda si el accidente no se hubiese producido. Por lo que cualquier método de calculo al respecto debe ser simplemente aproximativo, fundándose esencialmente en la razonable probabilidad del monto futuro de la ayuda y de su prolongación como estabilidad en el tiempo.

\section{ii.- Daño extrapatrimonial}

En relación a daño moral por repercusión o perjuicio de afectación, ${ }^{612}$ la legitimación es mucho más amplia en principio que en los daños patrimoniales, ya que, tienen derecho a solicitar reparación todos aquellos que hayan padecido un sufrimiento moral a consecuencia de la perdida o grave lesión de un ser querido.

Así lo señala Alessandri, afirmando que puede solicitarlo los que sufren en razón del suceso y que los hiere en sus propios sentimientos y efectos, aunque no sean ni herederos ni parientes,

${ }^{611}$ BARROS BOURIE, Ob. Cit., pp. 348-349

612 BARRos BouriE, Ob. Cit., pp. 349 y ss. 
puesto que la ley no tiene en su cuenta un vínculo en particular, ni limita la reparación de este daño a determinadas personas, a pesar de que no vivan a expensas de la víctima directa. ${ }^{613}$

Este mismo criterio ha sido defendido en Francia, por Mazeaud y Tunc, quienes rechazando cualquier tesis reductivista, afirmaron que el único criterio orientador en esta materia debe ser el pesar efectivamente causado a las víctimas por rebote, y que, por lo mismo, tienen derecho a ser indemnizado todo aquel y sólo aquel que haya experimentado un daño moral efectivo a consecuencia de la muerte o lesión del ser querido, el pesar experimentado, rebasa el círculo mismo de la familia, y es susceptible de afectar a cualquier persona. ${ }^{614}$

El daño moral reflejo, consiste en el perjuicio afectivo y en las cargas personales de cuidado que supone un accidente sufrido por una persona próxima. Debe ser distinguido de shock nervioso, que se sigue de una accidente, puesto que este se trata de un daño directo, que se traduce en un patología psicológica, medicamente diagnosticable a consecuencia del accidente. ${ }^{615}$

Pero fuera de la órbita de lo teórico, en la práctica es donde surgen lo verdaderos problemas, dado que, bajo el principio esbozado anteriormente, podrían ser ilimitadas las personas que sufran sinceramente un daño causado a la víctima directa.

${ }^{613}$ Alessandri Rodríguez, Ob. Cit., pp. 333-334.

${ }^{614}$ MAZEAUD, y TUNC, Ob. Cit., pp. 450 y ss.

${ }^{615}$ BARROS BOURIE, Ob. Cit., p. 350 
Se hace necesario sentar limitaciones y criterios, para determinar quienes efectivamente, puedan pretender la indemnización por daño reflejo, dentro de estos criterios merecen destacarse el criterio alimenticio, criterio de parientes muy próximos, criterio sucesorio entre otros.

En Francia, la doctrina y jurisprudencia, han hecho eco del principio indemnizatorio de que todo daño debe ser indemnizado, sean víctimas por rebote parientes, vinculados de derecho o de hecho de la víctima directa. ${ }^{616}$ Dentro de esta masa de sujetos, ocupa el primer lugar el cónyuge del lesionado y sus hijos mayores o menores. En el caso de estos sujetos el problema probatorio resulta muy atenuado, pues, en lo referente al daño moral, existe la presunción de hecho que opera a su favor. ${ }^{617}$

En el caso de los restantes miembros de la familia tienen derecho el derecho a esta indemnización por el daño moral ocasionado, pero deben aportar prueba suficiente del sufrimiento que han experimentado. ${ }^{618}$

En Chile, existe un amplio reconocimiento de la reparabilidad del perjuicio afectivo que sigue de la muerte de una persona muy cercana. Más exigente ha sido tradicionalmente la reparación del perjuicio afectivo que se sigue de lesiones corporales a la víctima directa. En estos casos, la reparación del daño moral que pretenden terceros concurre con la acción personal de la víctima.

\footnotetext{
${ }^{616}$ VINEY Y MARKESINIS, Ob. Cit., pp. 82-83.

617 MAZEAUD, y TUNC, Ob. Cit., p. 452.; VINEY y MARKESINIS, Ob. Cit., pp. 82-83.

${ }^{618}$ VINEY y MARKESINIS, Ob. Cit., p. 83.
} 
De esta manera, se han exigido requisitos adicionales respecto a la intensidad del dolor y de la carga emocional, como en cuanto a la prueba de su efectiva materialización. ${ }^{619}$ En este sentido, la jurisprudencia chilena, tiende definir los titulares de la acción de acuerdo a la cercanía que dan la relación conyugal y el parentesco, de modo que los parientes más cercanos excluyen a los más remotos. ${ }^{620}$

Expuesto a lo menos someramente los alcances y principios por los cuales se rigen la categoría de daño precitada, toca ahora, referirse a un particular supuesto dentro de los daños por repercusión, que nos vincula directamente con nuestro objeto de estudio.

3.- RÉGIMEN ESPECIAL DE RESPONSABILIDAD CIVIL POR INFRACCIÓN DEL DEBER DE PROTECCIÓN RESPECTO DEL DAÑO REFLEJO O REBOTE

El incumplimiento contractual, también puede ser causa de daño reflejo, por cuanto, terceros ajenos al vínculo contractual, pueden verse perjudicados por los efectos expansivos del contrato. En este orden de ideas, el daño ocasionado por el incumplimiento del deudor, no solo afecta al acreedor, sino también a terceros vinculados estrechamente con él.

\footnotetext{
${ }^{619}$ BARROS BOURIE, Ob. Cit., pp. 351-352.

${ }^{620}$ Corte Suprema, 16 de diciembre de 1922, en Revista de Derecho y Jurisprudencia $(R D J)$ t. XXI, sec. $1^{\text {a }}$, p. 1053.; Corte Suprema, 14 de agosto de 1928, en RDJ, t. XXVI, sec. $1^{\mathrm{a}}$, p. 141.; Corte Suprema, 28 de enero de 1999 en RDJ, t. XCVI, sec. 4a, p. 71.; Corte Suprema,13 de marzo de 1999, en Fallos del Mes ( $F$. del M.) No 485, p. 302.; Corte Suprema, 19 de diciembre de 2000, en Gaceta Jurídica (GJ) N N 246, p.122.; Corte Suprema, 25 de septiembre de 2001 en F. del M. No 502, p. 2784.; Corte Suprema, 29 de enero de 2002, GJ NN 259, p.17.; Corte Suprema, 5 de junio de 2006, Rol № 6118-2005.
} 
En este caso, las víctimas por daño reflejo o rebote, para pretender la reparación de los daños, solo podrán sostenerse en las nomas que gobiernan la responsabilidad extracontractual, pues, no son parte del contrato, ni continuadoras de la personalidad de la contraparte afectada. ${ }^{621}$

Esta última premisa, no se verifica en el caso de la infracción de los deberes de protección, por cuanto, al ser este un deber específico de diligencia o cuidado, precipita y permea la frontera del contrato traspasando dicho límite hacia otras víctimas diversas, que comparten el mismo círculo de tutela que el acreedor, ya sea, por su proximidad o por su especial vínculo con aquel.

Así, estas víctimas por daño reflejo o rebote, para solicitar la reparación del daño causado, invocaran el incumplimiento de estos deberes, como constitutivo del régimen de responsabilidad que los ampara, el que a su vez, se funda en las normas de la responsabilidad aquiliana, en forma supletoria, dado su carácter de régimen común con algunas variaciones y flexibilizaciones a su favor.

Este fenómeno que explicaremos enseguida, conforma a nuestro juicio, un verdadero régimen especial de responsabilidad, cuyo fundamento se encuentra en la violación del deber de protección vulnerado. Desde esta perspectiva, las víctimas por rebote, fundan para solicitar el resarcimiento de los daños causados, el deber de protección infraccionado, y no directamente en el deber general de diligencia o "neminem laedere," contenido en el articulo 2314 del Código Civil chileno. De esta manera, el articulo 2314, actúa en estos

${ }^{621}$ MAZEAUD, y TUNC, Ob. Cit., p. 531. 
casos, como una norma de reenvío, que reconduce la ilicitud del daño y la antijuridicidad de la conducta, a la violación del deber de protección.

\section{a.- Presupuesto de antijuridicidad}

Como veremos a continuación, será un requisito para la construcción de un régimen especial de responsabilidad, aceptar tempranamente la antijuridicidad como un presupuesto de la responsabilidad extracontractual.

No obstante lo convencido que podremos estar de aquello, debemos reconocer de igual manera, que la antijuridicidad es un concepto cuya presencia entre los presupuestos de responsabilidad es muy debatida. ${ }^{622}$ Quizás el origen de esta cuestión, se deba a la existencia de varias acepciones diversas del termino antijuridicidad, algunas de las cuales convienen muy poco a la forma de ser de la responsabilidad civil. ${ }^{623} \mathrm{O}$ quizás también en parte, se deba a la gran confusión que existe del término antijuridicidad con la culpabilidad y, particularmente con la culpa. ${ }^{624}$

\footnotetext{
${ }^{622}$ La doctrina ha elaborado variadas teorías sobre la antijuridicidad como elemento de la responsabilidad civil. Dentro de ellas se encuentran, las teorías denominadas clásicas, que estiman que la antijuridicidad es un elemento de la responsabilidad, bien ya sea como componente de la culpa, ya sea como un elemento independiente a ésta última. Véase al respecto Busto LAGO, José Manuel, La antijuridicidad y la licitud e ilicitud de la conducta, en: Derechos de Daños, Primera Parte, ediciones la Rocca, $1^{\text {a }}$ ed., 1996, pp. 53 y ss.

${ }^{623}$ RegleRo CAMPOS, L. Fernando, "Conceptos generales y elementos de delimitación" en (Coord.) Reglero Campos, Fernando, Busto Lago, José, Tratado de Responsabilidad Civil t. I., $5^{\mathrm{a}}$ ed., Thomson Reuters Aranzadi, Navarra, 2014, p. 76.

${ }^{624}$ Aedo BarRenA, Cristian, Responsabilidad extracontractual, Librotecnia, Santiago, 2006, p. 243.
} 
Una ilustración de este orden de ideas, se encuentra en la profesora Sánchez-Friera, ${ }^{625}$ quien siguiendo a Pantaleón, indica que el concepto de antijuridicidad corresponde a tres posibles acepciones. La primera, referente a una concepción objetiva centrada en el desvalor del resultado en sentido propio, es decir, la antijuridicidad consistiría en la violación de una norma jurídica primaria que protege el bien jurídico o derecho subjetivo lesionado. La segunda acepción corresponde al desvalor del resultado en sentido impropio, o sea, la existencia de un deber jurídico absoluto de neminem laedere, así la antijuridicidad es la mera causación del daño, a menos que concurra una causa de justificación. $\mathrm{Y}$, por último la tercera, centrada en la conducta, que nos indica que la conducta es antijurídica por ser dolosa o negligente.

Sin perjuicio de lo señalado precedentemente, subraya Reglero, ${ }^{626}$ la acepción más conocida y profana de la antijuridicidad, relaciona a ésta con las conductas humanas concretas contrarias a las exigencias de comportamiento que impone el Derecho a sus destinatarios, es decir, una conducta es antijurídica cuando es contraria a lo que el ordenamiento considera correcto.

Agrega el autor, que puede afirmarse con carácter general que así entendida, la antijuridicidad no es en nuestro ordenamiento un presupuesto autónomo de la responsabilidad por daños, desde el momento en que la responsabilidad puede nacer como consecuencia

\footnotetext{
${ }^{625}$ SÁNCHEZ-FrIERA GonZÁleZ, María del Carmen, La responsabilidad civil del empresario por deterioro del medio ambiente, Bosch, $1^{\text {a }}$ ed., Barcelona, 1994, pp. 211-212.

${ }^{626}$ Reglero Campos, "Conceptos generales ... Ob. Cit., p 76.
} 
del desarrollo de actividades lícitas no cabe hablar de conducta antijurídica de quien las realiza. ${ }^{627}$

Por el contrario, pensamos que la antijuridicidad para configurar un presupuesto autónomo de la responsabilidad civil, debe liberarse por completo del terreno de la valoración de las conductas, trasladando su faena hacia el campo de los intereses razonables de tutela jurídica, toda vez que, como sabemos, una de las funciones prioritarias del ordenamiento jurídico es el de constituir un criterio justo y razonable, acerca de cuales de los innumerables intereses en juego en las relaciones sociales son dignos de la tutela del derecho y cuales no.

Siguiendo los términos de Peña López, ${ }^{628}$ para que el derecho reaccione, por definición, es necesario que el hecho dañoso afecte a un bien jurídicamente relevante, sin un momento dogmático en el juicio de responsabilidad en el que se dilucide esta cuestión no se podría conocer cuándo debe intervenir el Derecho y cuando no.

En este escenario, la antijuridicidad entendida en su concepción objetiva tendrá un rol fundamental en determinar el ámbito de lo jurídicamente relevante para el Derecho. Pues, los ordenamientos jurídicos, herederos del influjo codificador y su clausula general de responsabilidad, constituyen un sistema atípico y abstracto, en el que cualquier daño puede ser resarcido con tal que sea objeto de tutela jurídica previa, transformando a la antijuridicidad en un elemento imprescindible en el ámbito de la responsabilidad civil. Sobre este

\footnotetext{
${ }^{627}$ Ibídem, Ob. Cit., p 77.

${ }^{628}$ PEÑA LÓPEZ, Fernando, La culpabilidad en la responsabilidad civil extracontractual, Comares, Granada, 2002, p. 259.
} 
particular agrega Bueres: "Está muy claro que esta manera de enfocar la cuestión es errada, dado que violar el contrato -y, por tanto la leyo violar lisa y llanamente la ley o el ordenamiento, configura simplemente una ilicitud objetiva (antijuridicidad). ${ }^{629}$

Resume todo con especial elocuencia el profesor Reglero, al señalar: "Así, pues, la antijuridicidad en el ámbito del Derecho de daños esta relacionada directamente con el resultado de la conducta del sujeto, y más concreto con el hecho de que ese resultado haya lesionado un interés jurídicamente relevante. La consideración de la conducta activa u omisiva del agente del daño al que aquella responsabilidad pretende imputarse puede tener alguna relevancia secundaria, (causas de justificación) pero no constituye el objeto de valoración básico del juicio de antijuridicidad. De esta manera, conductas que en sí mismas consideradas son lícitas, sin embargo pueden generar daños en la esfera jurídica ajena que pueden ser calificados como antijurídicos. Para ello, el daño fruto de aquellas actividades -independientes de que sean lícitas o ilícitas- ha de estar constituido por la lesión de un derecho subjetivo o de un interés jurídicamente protegido. En consecuencia, la antijuridicidad se configura como un presupuesto de la responsabilidad civil extracontractual de marcado carácter objetivo, como contravención del interés digno de tutela, cuyo resarcimiento se pretende a través de aquel mecanismo. ${ }^{630}$

\footnotetext{
${ }^{629}$ BUERES, Alberto, Derecho de Daños, Buenos Aires, Hammurabi, 2001, p. 329.

${ }^{630}$ Reglero Campos, "Conceptos generales ... Ob. Cit., p. 78.
} 
b.- Mecanismo

La razón de afirmar que es un requisito para la construcción de este régimen especial, el aceptar la antijuridicidad como un presupuesto de la responsabilidad civil, estriba en que esta última se presenta como una condición indispensable para poder imputar el daño a un sujeto distinto de la víctima, como es justo la hipótesis de las víctimas por rebote o repercusión ya estudiado.

Por cuanto, la antijuridicidad actúa como mecanismo de control de los intereses jurídicamente relevantes, de lo que se sigue que al ser estos relevantes para el Derecho, su lesión importa la obligación de su resarcimiento por el agente, con total independencia si el paciente es directo o indirecto.

Para sostener funcionalmente dicha abstracción, es necesario reconocer la premisa que el principio del alterum non laedere contenido en la cláusula general de responsabilidad, no conforma más que el principio general de diligencia, que si bien determina la antijuridicidad en la mayor parte de los casos, no excluye otros casos en que la antijuridicidad se funda en una norma especial. ${ }^{631}$

El alterum non laedere, desde esta perspectiva, no es una fuente autónoma de protección, si no un precepto secundario que forzosamente se remite a otra norma o principio, para la individualización de la fuente de tutela del interés. ${ }^{632}$ De este modo, la

\footnotetext{
${ }^{631}$ RodRíGUEZ GREZ, Pablo, Responsabilidad extracontractual, Editorial jurídica, Santiago, 1999, p. 134.

${ }^{632}$ AeDo BARREnA, Responsabilidad extracontractual ...Ob. Cit., p. 250.
} 
lesión a intereses jurídicamente tutelados implica no la vulneración del principio alterum non laedere, sino que éste reconduce la ilicitud a las distintas normas o deberes que consagran o protegen los bienes jurídicos

Reafirma la idea planteada, el análisis de artículo 2329 inciso $1^{\circ}$ del Código Civil, que señala que por regla general todo daño que pueda imputarse a malicia o negligencia de otra persona debe ser reparado por esta. No hace más que incorporar una regla general sobre la antijuridicidad de ciertos actos (dolosos y culposos), pero no agota ni cierra la construcción de la antijuridicidad, que, como ya se dijo, puede presentarse a partir de una norma o deber especial que la contemple sin que medie dolo o culpa. ${ }^{63}$

En consecuencia, en el sentido de nuestra investigación, resulta del todo congruente, afirmar que la violación del deber de protección, comporta la infracción del interés jurídicamente tutelado, ya sea, por las partes, el legislador o la buena fe. En el caso de las victimas reflejas o por rebote, este deber de protección vulnerado, configura un régimen especial de responsabilidad civil, por remisión del alterum non laedere, el que, como se ha afirmado, reconduce la antijuridicidad del daño a éste deber secundario de prestación.

c.- Consecuencia del régimen especial

${ }^{633}$ Rodríguez GREZ, Responsabilidad extracontractual... Ob. Cit., p. 143. 
Este régimen especial de responsabilidad, tiene como supletorio las normas de la responsabilidad aquiliana en su función de régimen común de responsabilidad, ${ }^{634}$ con ciertas particularidades jurídicas interesantes.

En este contexto, las víctimas por daño reflejo o rebote, para solicitar la reparación del daño causado, invocaran el incumplimiento de los deberes de protección, como constitutivo del régimen de responsabilidad que los ampara, es decir, no invocaran el deber de cuidado o de abstención general contenido en el principio neminen laedere, sino, que se escudaran en el deber de protección vulnerado, que al ser un deber específico de diligencia, tutela de mejor manera los contornos de los intereses y bienes jurídicos sujetos a su cuidado.

Esto conducirá a sostener, que la naturaleza del deber de protección (obligación de resultado ${ }^{635}$ ) -constituyente de este régimen especial-, traspase la frontera del contrato, elevando el estándar de conducta exigible al deudor-agente del daño, por cuanto, éste es responsable desde que dicho resultado no es alcanzado, que en el caso de las víctimas por rebote, ya se encuentra verificado con la infracción del deber de protección, situación de la cual sólo podrá escapar probando la existencia de fuerza mayor o caso fortuito. ${ }^{636}$

\footnotetext{
${ }^{634} \mathrm{El}$ régimen común lo constituye claramente las normas de la responsabilidad aquiliana, no obstante, existe una doctrina que considera el régimen común es el de la responsabilidad contractual, justificando el carácter general de las normas contractuales, en Chile por ejemplo sostienen esta teoría, ALESSANDRI RODRÍGUEZ, De la responsabilidad extracontractual ... Ob. Cit., pp. 43 y ss; CLARO SOLAR, Explicaciones de Derecho Civil chileno y comparado... Ob. Cit., pp. 522-523; AbelIUK MANASEVICH, Ob. Cit., t. II, pp. 761762, RAmos PAZOS, Rene, De las obligaciones, Editorial jurídica, Santiago, 1999, pp. 240 241, LaRRAín Ríos, Teoría general de las obligaciones, Lexis Nexis, Santiago, 2002, pp. 212 y ss.

${ }^{635}$ Véase, Supra, pp.149 y ss.

${ }^{636}$ ARROYO MATTEUCC, Marcela Valeria, "Breve Comentario sobre obligaciones determinadas o de resultado y obligaciones generales de Prudencia y diligencia o de
} 
En este orden de ideas, existe una especie de objetivación de la responsabilidad del agente respecto de estas víctimas, dado que solo basta a éstas probar el daño reflejo respectivo para configurar la responsabilidad.

Esta especie de objetivación, se refiere a una flexibilización de la carga de la prueba que obra a favor de estas víctimas, ya que, al ser el deber de protección una obligación de resultado, siempre acarreara con su infracción el no cumplimiento del resultado esperado, que en lo que nos incumbe, es la indemnidad del interés tutelado.

Por lo tanto, salvo caso fortuito o fuerza mayor, el agente deberá responder de los daños ocasionados a las víctimas por rebote, lo que en efectos prácticos las libera del probar la culpa de agente.

Parece confirmar este contexto, el caso del deber de protección legal contenido en el en el art 184 del Código del Trabajo, en relación al art 69 de la Ley de Accidentes del Trabajo No 16.744. Dicho artículo prescribe: "El empleador estará obligado a tomar todas las medidas necesarias para proteger eficazmente la vida y salud de los trabajadores, informando de los posibles riesgos y manteniendo las condiciones adecuadas de higiene y seguridad en las faenas, como también los implementos necesarios para prevenir accidentes $y$ enfermedades profesionales."

Medios en la legislación y doctrina Francesas" en ARS BONI ET AEQUI (año $8 \mathrm{~N}^{\circ} 2$ ), p. 290 . 
La jurisprudencia más moderna ha entendido, -según el criterio definido desde el 2003- que el régimen para reclamar las indemnizaciones a que dicho artículo diere, respecto las víctimas por daño reflejo o rebote, es de orden extracontractual, siendo en consecuencia, competente el tribunal civiles ordinarios. ${ }^{637-638}$

Acá, la acción indemnizatoria no se entabla en la infracción del deber general de diligencia contenido en la cláusula general de responsabilidad del artículo 2314, sino, por el contrario, dicha acción se funda en la inobservancia del deber de protección legal contenido en el precitado artículo 184 del Código del Trabajo, es decir, las víctimas por rebote invocan para generar el régimen de responsabilidad aplicable, no la culpa o el dolo del 2314, sino la vulneración al deber de protección, que actúa como norma de reenvío de la antijuridicidad de su régimen especial de responsabilidad.

Lo que ocasiona ciertamente, una notable incidencia en sistema de responsabilidad civil, puesto que, el estándar de diligencia es específico y más elevado respecto al general.

\footnotetext{
${ }^{637}$ Es el fallo de la Corte Suprema de 19 agosto de 2003 el que hará la distinción radical, produciendo el giro jurisprudencial, al fallo precitado le siguieron los de 26 de agosto de 2003, 2 de octubre de 2003 y 11 de mayo de 2004. Se entiende que actúan a título personal y no como sucesores de la víctima, de modo que a la víctima se le otorga una opción: como sucesor (régimen contractual); daño por rebote (régimen extracontractual). Véase, Corte Suprema, 19 de agosto de 2003 en GJ, Nº 278, p. 252; Corte Suprema, 26 agosto de 2003 en $F$ del M, $N^{\circ} 513$, p. 2155; Corte Suprema, 02 octubre de 2003, en GJ, $N^{\circ}$ 280 , p. 279 ss.

${ }^{638}$ Así, por ejemplo, se ha hecho presente que "la demandante es un tercero que no tiene ni ha acreditado relación laboral alguna con el demandado. No se trata de una cuestión entre trabajador y empleador, ni tampoco se ha ejercido acción en calidad de sucesora del dependiente afectado. Es decir, ciertamente entonces, la cónyuge sobreviviente del trabajador fallecido pretende hacer efectiva una responsabilidad de naturaleza extracontractual, ya que ninguna vinculación la ha unido al demandado principal, por ende, no puede considerarse, en este caso, que la proteja la obligación que recae sobre el empleador de adoptar todas las medidas de seguridad pertinentes" (Corte Suprema, 19 de agosto de 2003, en GJ, № 278, p. 252 y ss., considerando sexto).
} 
En este orden de ideas, la jurisprudencia ha señalado que la expresión "eficazmente" utilizada en el artículo 184 del Código del Trabajo ha sido entendida como "suma exigencia," 639 "máxima diligencia,"640 "sumo cuidado," ${ }^{641}$ exigiendo "resultados positivos," ${ }^{\text {"42 }}$ o apuntando "a un efecto de resultado," ${ }^{433}$ confirmando el carácter del especial del régimen de responsabilidad en comento. ${ }^{644}$

${ }^{639}$ Corte Suprema, 27 de mayo de 1999 , en RDJ, t.96, sec. $3^{\mathrm{a}}$, pp. 89 y ss.

${ }^{640}$ Corte de Apelaciones de Santiago, 25 de octubre de 2000, en GJ, No 245, pp. 233 y ss.

${ }^{641}$ Corte de Apelaciones de Santiago, 19 de enero de 1999, en GJ, No 223, pp. 209 y ss.

${ }^{642}$ Corte de Apelaciones de Rancagua, 21 de noviembre de 2003, Lexis Nexis № 29895.

${ }^{643}$ Corte Suprema, 27 de mayo de 1999, en $R D J$, t.96, sec. $3^{\mathrm{a}}$, pp. 89, y ss.

${ }^{644}$ Así por ejemplo: Corte de Apelaciones de Santiago: 25 de noviembre de 1998, en GJ, $\mathrm{N}^{\circ} 221$, pp. 200 y ss.; Corte Suprema, 27 de mayo de 1999, en RDJ, t. 96, sec. $3^{\mathrm{a}}$, pp. 89 y ss.; Corte de Apelaciones de Santiago, 17 de enero de 2000, en GJ, № 235, pp. 199 y ss; Corte Suprema, 8 de agosto de 2000, en RDJ, t. 97, sec. $3^{\text {a }}$, pp. 152 y ss.; Corte de Apelaciones de Santiago, 25 de octubre de 2000, en GJ, N ${ }^{\circ} 245$, pp. 233 y ss.; Corte de Apelaciones de Concepción, 20 de mayo de 2002, en GJ, $N^{\circ} 270$, pp. 160 y ss. (citando a su vez fallo de la Corte Suprema, publicado en RDJ, t. 96, sec. $3^{\text {a }}$, p. 89 ss.); Corte de Apelaciones de Concepción, 10 de julio de 2002, confirmada por Corte Suprema, en fallo de 20 de enero de 2003, ambas en $F$ del $M, N^{\circ} 506$, pp. 5267 y ss. 


\section{CONCLUSIONES}

Expone sabiamente Ricardo de Ángel, en su obra La responsabilidad civil: "el no causar daño a los demás es quizá, la más importante regla de las que gobiernan la convivencia humana. ${ }^{645} \mathrm{En}$ el transcurso de nuestra investigación, nos hemos convencido que dicho principio, no debe ser entendido como un patrimonio exclusivo de la responsabilidad aquiliana, ni debe ser conducido unidireccionalmente a dar contenido a ella.

Por el contrario, tal máxima encuentra una concreción mucho más íntima en el contacto social que genera la relación obligatoria. Pues, sí constituye un deber respetar la indemnidad de la esfera jurídica del otro, para cualquier integrante indeterminado de la sociedad, con mayor, razón lo será para dos partes vinculadas por un contrato, que es una relación específica y especial de contacto.

En el desarrollo de nuestro trabajo, hemos observado que junto al interés principal del acreedor a la realización de la prestación principal, convive otro interés independiente a este último, cuyo objeto es evitar que del vinculo deriven daños a la persona o patrimonio de las partes en la relación obligatoria. Esta noción importa la creación de un especial deber secundario de conducta: los deberes de protección. 645 De ANGEL YÁGÚEZ, Ricardo de, La responsabilidad civil, $2^{\mathrm{a}}$ ed. Universidad de Deusto,
Bilbao, 1989, p. 21. 
La teoría de los deberes de protección, propone ocupar un espacio hasta ese entonces desconocido en el sistema de responsabilidad civil, desplegando una importante contribución práctica en la dogmática moderna. Sobre el estudio de este instituto y bajo nuestra especial perspectiva, hemos enumerado las siguientes conclusiones.

1.- A causa de las grandes transformaciones sociales y el decisivo progreso experimentado por humanidad en los últimos siglos. La concepción clásica de la obligación queda relegada de su fisonomía tradicional. El inevitable tránsito de la economía agraria a la industrial, constituirá un motor para la evolución del campo de las obligaciones.

2.- Con la llegada de la modernidad, se apuntan valiosos impulsos hacia una concepción más realista de la obligación, con miras a tener en cuenta los diversos elementos implicados en ella. Bajo este respecto y en contraste a la noción clásica, la obligación se entenderá como una relación obligatoria compleja, es decir, desde una visión orgánica, en que el crédito se presenta como un conjunto complejo de facultades y junto con ellos cargas y deberes derivados de la cooperación que debe prestar en el pago, y, correlativamente la deuda como un conjunto complejo de deberes, acompañado de derechos y facultades.

3.- El carácter orgánico y complejo de la relación obligacional moderna, afecta la noción de prestación, añadiendo y ampliando su 
contenido. Ésta deja de concebirse linealmente, alterando notoriamente su conformación típica y técnica. Coloca junto a ella, una serie de conductas o deberes que sirven de apoyo a esta última, haciéndola más idónea para el logro del fin al cual se dirige. Bajo esta perspectiva pasa a ser concebida como una relación global que alberga en su seno diversos vínculos y situaciones jurídicas.

4.- Estos deberes integran y ensanchan el contenido de la prestación principal, formando de manera inmediata una parte esencial de ella. Su carácter secundario o complementario se predica de la ejecución o cumplimiento del deber de prestación, que en todo caso, se sigue considerando como la finalidad principal perseguida por las partes. En términos generales, estos deberes son formas de cooperación o de colaboración al resultado de la prestación y tienden hacer posible la máxima utilidad de ésta, pero se encuentran siempre encuadrados dentro de ella o en conexión con ella.

5.- Dentro de los deberes secundarios de conducta o accesorios a la prestación, se encuentra una clase de deber muy particular, denominado deber de protección u obligación de seguridad. Éstos, tienen un sentido propio respecto de los restantes deberes que se integran en la relación obligatoria, porque ellos buscan evitar los daños que amenazan los bienes jurídicos de los interesados en la ejecución del contrato. Tales deberes, surgen frente a los peligros derivados del contacto social al que la relación obligatoria debe necesariamente dar lugar. A diferencia de los deberes de accesorios, los deberes de protección tienen un contenido autónomo respecto al deber de prestación, de modo que, desde la perspectiva del deudor, 
estos deberes operan con independencia de que la prestación principal se haya cumplido.

6.- En cuanto a su naturaleza, hemos decidido inclinarnos por la naturaleza contractual de los deberes de protección en desmedro de las tesis precontractual y extracontractual, ya que, es evidente que es en el ámbito del contrato donde mejor justifica su síntesis, toda vez, que concurren a la realización del objeto de la relación obligatoria considerado en términos globales u orgánicos. El carácter contractual de los deberes de protección, emana del contacto social entre las partes y justifica su configuración como auténticos deberes contractuales, autónomos e independientes de la prestación principal y de los demás deberes accesorios relacionados con ella. De este modo, la noción de responsabilidad contractual se entiende en toda su dimensión, es decir, frente al incumplimiento en sentido estricto o técnico (de la prestación), surgen igualmente supuestos de incumplimientos de estos deberes de protección de naturaleza contractual.

7.- Los deberes de protección responden a un interés de las partes que resulta autónomo al interés de la prestación. Esta autonomía es una consecuencia inmediata del sentido orgánicocomplejo de la relación obligacional. Esta afirmación, reporta a su vez importantes cambios en la forma de ver y entender en el ámbito de responsabilidad contractual, por cuanto, el cumplimiento puntual de las obligaciones contractuales no se presentaría como limitado a la mera realización de los deberes de prestación principal, sino que implicaría además que la actuación desarrollada no provocase perjuicios en las personas o bienes del acreedor. 
8.- En cuanto a su contenido, el deber de protección solo tiene sentido si se concibe como una genuina obligación de resultado. Resulta indiscutible el hecho que cuando la seguridad o protección es el objeto de la obligación, no puede admitirse un termino medio, toda vez, que su ejecución no es susceptible de división jurídica, o se la garantiza mediante un típico deber de fines, o lo que está en juego es otra cosa, una obligación de prudencia y diligencia. De allí que, o bien la obligación de seguridad es de resultado o ella no es contractual. Por el contario, un reconocimiento del deber de protección como una obligación medios no agrega en nada a la protección de la víctima, sino todo lo contrario, la empobrece. En este sentido, el deber de protección u obligación de seguridad pertenece por naturaleza a la categoría de las obligaciones de resultado, pues, siendo la obligación de seguridad concebida en interés exclusivo de las víctimas, su reconocimiento solo se justifica, o sea, su objetivo solo se alcanza, cuando es de resultado.

9.- La inobservancia de los deberes de protección producen una contractualización de los daños generados. Tal abstracción presupone la idea de que un sujeto que entra en contacto con otro, mediante una relación obligatoria, expone su propia esfera jurídica a riesgos que de otra manera no le afectaría, es decir, entra en una específica zona de peligro, determinada por la posibilidad de la actividad de la otra parte, conexa al desarrollo de la relación obligacional.

10.- En relación al criterio para justificar la contractualización de los daños, será la propia obligación quien nos dirá cuales son los cuidados, atenciones y cautelas cuya observancia es exigible 
específicamente del deudor de esa concreta prestación, y inversamente qué daños del acreedor entrañan infracción contractual, que importen una violación de un deber específico-obligacional de protección. En este orden de idea, será imperioso que dichos daños tengan una correspondencia funcional con el objeto de la obligación principal, es decir, que exista una conexión suficientemente estrecha entre la ejecución de la obligación y la salvaguardia de los bienes.

11.- La identificación de esta causalidad entre la ejecución de la relación obligatoria y el daño de un interés diverso del de prestación, ha de proceder según una valoración típica del contrato, teniendo en cuenta la específica posibilidad de injerencia dañosa que ofrece la relación obligatoria de que se trate. Debe tratarse de un tipo contractual, que haga razonable pensar que circunstancias inherentes a la convención tornen necesario afianzar la protección de la indemnidad de uno de los contratantes.

12.- El fundamento normativo principal de los deberes de protección, es decir, la razón por la que el Derecho supone como justificado la incorporación de los deberes de protección en la relación obligacional, lo constituye para nosotros, el principio general de la buena fe.

13.- La buena fe se organiza en un ideal de comportamiento en la vida social que ésta incorporado al orden jurídico desde la época del derecho romano, constituyendo un principio universal, trascendente, reconocido y aceptado. Así, la buena fe aparece como un principio de conducta debida, que mantiene el control de la autonomía privada. De esta manera se integran por su intermedio la 
necesidad de tutelar los valores inviolables de la persona, entre otras múltiples funciones que la buena fe cumple como principio general de derecho.

14.- Hoy se asume con total naturalidad que en el contrato aparezcan obligaciones que las partes no han previsto expresamente. Estos deberes u obligaciones se presentarán como un "plus" de la relación obligatoria, integrando o ampliando su contenido. Los cuales operarán en algunos casos integrando o corrigiendo la voluntad de las partes, y en otros actuarán como limite al ejercicio abusivo del derecho, que se impone con fuerza normativa autónoma y originaria en las relaciones contractuales, fijando con ello poderes y deberes.

15.- De esta manera, la fuente de los deberes de protección no se encuentra en la voluntad de las partes, sino que la propia ley, que vincula al contrato todas las consecuencias que el principio general de la buena fe da a la obligación de acuerdo a la naturaleza del propio contrato, claro reflejo del remanente romano, y de su inclusión normativa forjada por codificación. La buena fe, accede los deberes de protección a la relación obligatoria, mediante procesos integrativos, jurígenos y correctores.

16.- La buena fe integradora, produce un enriquecimiento del contenido contractual, ya que a través de ella se dota de un sentido más amplio a los deberes creados por el contrato que atenderán particularmente a la naturaleza del mismo y a su finalidad. Así, los deberes de protección accederán a la relación obligatoria integrados por la buena fe, los cuales serán plenamente exigibles por ambas partes, por cuanto, ambas tienen la obligación de cooperar para lograr 
que se satisfaga el interés integro del contenido del contrato, esto es, tanto el interés propio de la prestación, como la indemnidad de las partes en la prosecución del mismo.

17.- La función jurígena de la buena fe, que ha estado unidad a su evolución desde su inicio, ordena que esta última, no solo opere supliendo "lagunas", o iluminando la oscuridad de las expresiones de los contratantes, sino que también cree derechos y obligaciones, es decir, tiene una potencialidad jurígena real de crear derechos y obligaciones ampliando el contenido de la relación contractual. De este modo la aplicación de la cláusula general de la buena fe, genera dentro de la relación obligatoria ciertos deberes especiales de conducta, -los deberes de protección- que deberán ser cumplidos por la partes tal cual como sus pretensiones, por cuanto, estos deberes son plenamente exigibles.

18.- La buena fe en su faz correctora, importa un claro limite a la autonomía privada, corrigiendo o enmendando las estipulaciones contractuales que nos se ajusten a ella. En este sentido el juez puede y debe, no solo integrar o insertar obligaciones o deberes secundarios no previstos por las partes, sino que puede abolir aquellas disposiciones expresas que se aparten de la clausula general de la buena fe corrigiéndolas. En este orden de ideas, los deberes de protección se vinculan a la relación obligacional corrigiendo y modificando la voluntad de la partes en la medida que estas se han alejado de la patrón de conducta debida que significa la cláusula general de la buena fe. 
19.- Sin perjuicio, de la suficiencia e idoneidad de la buena fe como fundamento normativo inmediato del deber de protección. Existen en el ordenamiento jurídico otros supuestos normativos indirectos que dan justificación a los deberes de protección. Nos referimos a la teoría del abuso del derecho y los instrumentos de Soft Law .

20.- En este sentido, cualquier determinación obligo-contractual absoluta, efectuada sin respeto alguno a los intereses de la contraparte, rompe el equilibrio y relatividad de los derechos prestacionales, importando con ello un acto abusivo, por cuanto, la parte sometida debe aceptar una decisión aunque licita, pero absoluta del interés de prestación, usado libre e ilimitadamente en cuanto a tal.

21.- Los deberes de protección representan en la relación obligatoria un limite cierto al ejercicio absoluto de los derechos subjetivos de las partes. Su inobservancia o vulneración, constituye un acto abusivo, por cuanto importa un ejercicio excesivo o anormal del interés de prestación, pues, cualquier actividad que en involucre daño a la persona o patrimonio de la contraparte, aunque sea lícita y en pos de la realización de la prestación principal, sobrepasa con creces los limites normales del interés propio.

22.- El Soft Law ha proporcionado pautas valiosas a la jurisprudencia y la doctrina en la modernización de aspectos de los derechos de obligaciones, contratos y daños. En lo referente a los deberes de protección, Los Principios de Derecho Europeo de la Responsabilidad Civil del European Group on Tort Law, consagran el deber actuar positivamente para proteger a los demás de daños (Art. 
4:103). Este reconocimiento manifiesto, configura un precedente importantísimo en el campo de nuestro estudio, ya que, elevan el deber positivo de protección de ciertos intereses, a una categoría en el Derecho de la responsabilidad civil. De igual manera se hace mención expresa a las obligaciones contractuales implícitas en los principios UNIDROIT (5.1.2) y en los apartados (1) y (2) del art. II9:101 del DCFR.

23.- La inserción de los deberes de protección en el ámbito del contrato, genera una contractualización de los daños, incorporando a este escenario, los atentados a la integridad física, psíquica y patrimonial de los contratantes. De este modo la noción de responsabilidad contractual resulta ampliada, pues junto a la responsabilidad por el incumplimiento en sentido estricto -derivada de la violación del deber de prestación- aparecen supuestos de violación de deberes de protección que se refieren a intereses diversos.

24.- La consecuencia fundamental que deriva de la infracción del deber de protección, es el derecho de la víctima a la indemnización de daños y perjuicios, ya que, aceptada la idea de que el deber de protección forma parte del contenido de la relación contractual, no es lógico negar al mismo el título de tutela (específica) que corresponde al deber de prestación.

25.- En Chile, no existe inconveniente para que los daños derivados de la inobservancia de los deberes de protección sean reparados por la vía del remedio contractual de la indemnización autónoma de perjuicios. En relación a los deberes de protección, estos se desenvuelven generalmente en la práctica como obligaciones 
de hacer (deberes de aviso y custodia) y no hacer (deberes de conservación y salvamento). De lo que se sigue, que no hay impedimento jurídico válido, aún en la tesis más restrictiva para negarle autonomía a la indemnización de perjuicios por infracción de un deber de protección en la relación obligacional. Pues, las reglas del Código Civil en la materia, prevén explícitamente esta posibilidad, artículo 1553 del Código Civil (obligaciones de hacer) y artículo 1555 Código Civil (obligaciones de no hacer).

26.- En relación a los daños indemnizables, se aplicaran las mismas reglas que para cualquier otra lesión de la relación contractual, tanto en la entidad del daño como en la carga de la prueba, ya que, la infracción de un deber de protección importa como hemos señalado, genuina responsabilidad por incumplimiento contractual.

27.- En relación a la de responsabilidad contractual indirecta, al ser esta última una norma de imputación total o global, actúa de forma exhaustiva sobre todos y cada uno de los aspectos que integran el contenido de lo debido por el deudor. El carácter total o exhaustivo del principio de la responsabilidad contractual del deudor por sus auxiliares implica que la misma realización del cumplimiento que el obligado debe como prudentes, atentas o cuidadosas, las sigue debiendo así, cuando en vez de cumplir o intervenir personalmente cumple o interviene utilizando un auxiliar. Por lo tanto, todo lo que se ha dicho en relación a la infracción de los deberes de protección, se predicará para la inobservancia del auxiliar utilizado por el deudor en su cumplimiento. 
29.- De no ser así, en el ámbito de los deberes de protección, la utilización de auxiliares de cumplimiento por el deudor menoscaba la tutela contractual del acreedor, reduciendo la esfera de lo exigible, en relación sí actuara personalmente, y redirigiendo a la víctima en este caso el concreto acreedor para resarcir los daños ocasionados a un estatuto de responsabilidad aquiliana, desplazando así a otro la otrora responsabilidad contractual.

30.- La responsabilidad contractual del deudor, por los daños derivados de la inobservancia del deber de protección, no solo se afirma frente a su acreedor, sino que, en determinadas condiciones, también puede afirmarse frente a terceros de algún modo relacionados con el acreedor (por ejemplo, sus familiares, clientes, visitantes, empleados), por causa de cuya relación entran, de alguna forma, en contacto con la prestación del deudor o se sitúan en proximidad a la misma.

32.- El efecto absoluto o expansivo de los contratos, corresponde ciertamente a una atenuación o inflexión de la teoría de la relatividad del contrato. El contrato, proyecta su eficacia más allá de la relación contractual a la que da origen, alcanzando a terceros extraños a su celebración, ya no como acto jurídico, sino como hecho que incide en la realidad jurídica. Es así, como perfectamente el incumplimiento contractual, puede ser fuente de riesgo y daño a terceros ajenos al vínculo contractual, y por ende, éste puede ser invocado por el tercero perjudicado, como causa de su daño.

33.- En el caso particular de las víctimas por rebote o daño reflejo, se genera un régimen especial de responsabilidad cuyo 
fundamento se encuentra en la violación del deber de protección vulnerado. Desde esta perspectiva, las víctimas por rebote, fundan para solicitar el resarcimiento de los daños causados, el deber de protección infraccionado, y no directamente en el deber general de diligencia o "neminem laedere," contenido en la clausula general de responsabilidad, que en el ordenamiento chileno se consagra en el artículo 2314 de Código Civil. De esta manera, dicho articulo, actúa en estos casos, como una norma de reenvío, que reconduce la ilicitud del daño y la antijuridicidad de la conducta, a la violación del deber de protección.

34.- Esto conducirá a sostener, que la naturaleza del deber de protección (obligación de resultado) -constituyente de este régimen especial-, traspase la frontera del contrato, elevando el estándar de conducta exigible al deudor-agente del daño, por cuanto, éste es responsable desde que dicho resultado no es alcanzado, que en el caso de las víctimas por rebote, ya se encuentra verificado con la infracción del deber de protección.

35.- En este sentido, existe una especie de objetivación de la responsabilidad del agente respecto de estas víctimas, flexibilizando la carga de la prueba que obra a favor de estas víctimas, ya que, al ser el deber de protección una obligación de resultado, se concluye que salvo caso fortuito o fuerza mayor, el agente deberá responder de los daños ocasionados a las víctimas por rebote, lo que en efectos prácticos las libera del probar la culpa de agente. 
CONCLUSIONES 


\section{BiBLIOGRAFÍA}

Abeliuk, ManaseVICH, Rene, Las obligaciones, t. I, editorial Jurídica, $4^{\text {a }}$ ed., Santiago, 2001.

Aedo BarRena, Cristian, Responsabilidad extracontractual, Librotecnia, Santiago, 2006.

-"Obligatio: In iure consistunt", en Revista Chilena de Derecho, vol. 40, No 3, 2013.

ALBERICI, G. Il dovere precontrattuale di buona fede, in Analisi della giurisprudeza, Rass. Dir. Civ. 1982.

Alcalde Rodríguez, Enrique, "La acción subrogatoria", en Revista Chilena de Derecho, Santiago, vol. 14, № 2-3, 1987.

AlcalÁ-Zamora y CAStillo, Niceto, "Enseñanzas y sugerencias de algunos procesalistas sudamericanos acerca de la acción”, en Estudios de teoría general e historia del proceso, Instituto de investigaciones jurídicas UNAM, México, 1974, t. I.

AlmeidA Mario Julio, Direito das obligações, Coimbra, 1979.

Alonzo PÉREZ, Mariano, "La responsabilidad precontractual," Revista critica de Derecho inmobiliario, 1971. 
Alonso García, Ricardo, "El Soft Law Comunitario", Revista de Administración Pública, Madrid, Núm. 154, Enero-Abril 2001.

ALPA, GUIDO, Appunti sulla buona fede integrativa nella prospettiva storica e del comercio internazionale, in il contratti, 2001.

AlPA, Guido, Bessone, Mario, 'L'integrazione del contratto in generale", in I Contratti in generale, Torino, UTET, 1999.

AlessandRI RodRíguez, Arturo, De la responsabilidad extracontractual en el Derecho Civil Chileno, Editorial Jurídica de Chile, Santiago, 2011.

Alvarez GonzÁlez, Norberto, "Intimidad: ¿Derecho de todos o privilegio de algunos?" en Anuario de la Facultad de Derecho, Universidad de Alcalá, 1998.

AMAT LLARI, Ma Eulalia, "La teoría de la relatividad del contrato y sus excepciones" en Estudios jurídicos en homenaje al profesor Luis Díez-Picazo, t. II., Derecho de obligaciones, Thomson-Civitas, Madrid, 2003.

ANTUNes VARELA, Joao de Matos, Das obrigaçes em geral, Almedina. 9a ed., Coimbra, 1996.

Aragonese, Pedro, Proceso y Derecho procesal, Ed. Aguilar, Madrid, 1960. 
ARAngIO-RuIZ, Vincenzo, Responsabilità contrattuale in diritto romano, reimpresión de la $1^{a}$ ed., Napoli, jovene, 1987.

ARroyo Matteucc, Marcela Valeria, "Breve Comentario sobre obligaciones determinadas o de resultado y obligaciones generales de Prudencia y diligencia o de Medios en la legislación y doctrina Francesas" en ARS BONI ET AEQUI (año $8 \mathrm{~N}^{\circ} 2$ ).

AsúA GonZÁlez, Clara, La culpa in contrahendo. Tratamiento en el Derecho alemán y presencia en otros ordenamientos, Servicio de publicaciones del la Universidad del País Vasco, Bilbao, 1989.

Atienza, Manuel, y Manero, Juan Ruiz. llícitos atípicos: sobre el abuso del derecho, el fraude a la ley y la desviación de poder, Editorial Trotta, Madrid, 2000.

Aubry ET RAU, Cours de Droit Civil Francais d'aprés la méthode de Zacharial. t. IV, París, 1902.

AZÚA REYES, Sergio, Los principios generales de derecho, Porrúa, México, 1986.

BARAHONA GONZÁLEZ, Jorge, et al, "La protección de los derechos de los consumidores en Chile" en AA.VV. Cuadernos de extensión jurídica No 12, Universidad de Los Andes, 2006.

BARBERIS, Julio, Formación de Derecho Internacional, Editorial Abaco, Buenos Aires, 1994. 
BARRIENTOS ZAMORANO, Marcelo, Daños y deberes en las tratativas preliminares de un contrato, Legal Publishing, Santiago, $2^{\mathrm{a}}$ ed., 2010.

BARROS BOURIE, Enrique, Tratado de responsabilidad extracontractual Editorial Jurídica, Santiago, 2010.

BeAUthier, Régine y RoRive, Isabelle (coord.), Le Code Napoleón, un ancêtre vénéré?, Mélanges offerts à Jacques Vanderlinden, Bruylant, Brúselas, 2004.

Bellissent, Jean, Contribution à l'analyse de la distinction des obligations de moyens et des résultat. À propos de l'évolution des ordres de responsabilité civile, Librairie Générale de Droit et de Jurisprudence, Paris, 2001.

BeLlo López, Andrés, Instituciones de derecho romano, lib. III, título. 14, en Obras completas de Andrés Bello, Caracas, La Casa de Bello, 1959, reimp. 1981.

BÉnABent, Alain, Droit civil. Les obligations, 9a éd., Librairie Générale de Droit et de Jurisprudence-Montchrestien, Paris, 2003.

BÉNAC-SCHMIDT, Françoise, LARROUMET Christian, voz "Responsabilité du fait d'auntri" en Enciclopedia Dalloz civil, Núm. 12, Paris, 1990. 
BenattI, Francesco, "Osservazioni in tema di doveri di protezione" en Rivista trimestrale di diritto e procadura civile, anno XIV, Giuffrè, Milano, 1960.

Bened Walters, Dafydd, "L'image du Code dans le contexte de la Common law en Grande-Bretagne et dans le Commonwealth britannique", en Régine Beauthier e Isabelle Rorive (coord.), Le Code Napoleón, un ancêtre vénéré? Mélanges offerts à Jacques Vanderlinden, Bruylant, Bruselas, 2004.

BETTI, Emilio, Diritto processuale civile italiano, Roma, 1963.

- Teoría general de las obligaciones, t.l., Revista de Derecho Privado, Madrid, 1969.

- Teoría general del negocio jurídico, Trad. A Martin Pérez, Comares, Granada, 2000.

BIANCA, Cesare Massimo, "Dell'inaddempimento delle obbligazioni. Art. 1.218-1.229" en Commentario del Codice Civile a cura di Scialoja e Branca, Bologna-Roma, 1965.

- La nozione di buona fede quale regola di comportamento contrattuale", Rivista Diritto Civile, I, 1993.

BigliazZi Geri, Lina Breccia, Umberto y Busnelli, Francesco, Diritto Civile, vol. 2, edizioni UTET, 1988. 
BIgliAZZI GerI, Lina, "Buona fede nel diritto civile", in Digesto delle discipline privatistiche, Sez. Civile, vol. II, Torino 1988.

Blasco Gasco, Francisco, et al, Derecho Civil, obligaciones y contratos, (coord.) Ma R. Valpuesta Fernández, Tirat lo Blanch, $3^{a}$ ed., Valencia, 1998.

BLOCH, Cyril, L'obligation contractuelle de sécurité, Presses Universitaires d'Aix-Marseille, 2002.

Boetsch Gillet, Cristian, La buena fe contractual, Editorial Jurídica de Chile, Santiago, 2011.

BOURRIÉ-QUENILLET, Martine, "Droit du dommage corporel et prix de la vie humaine" JCP $N^{\circ} 21,2004$.

BRECCIA, Umberto, Diligenza e buona fede nell' attuazione del rapporto obligatorio, Milano, Vol. I. 1968.

BRUn, Philippe, Responsabilité civile extracontractuelle, Litec, Paris, 2005.

-"Les hypothèses les plus variées" en Responsabilité civile extracontractuelle, Litec, Paris, 2005.

BUCHER, Eugen, "La diversidad de significados de la relación obligatoria en el Código Civil alemán y las tradicionales fuentes extralegales de las obligaciones," en Revista para el Análisis del Derecho, Barcelona, 2006. 
Bueres, Alberto, Derecho de Daños, Buenos Aires, Hammurabi, 2001.

BusnelLI, Francesco, Donato, "Note in tema di buona fede ed equità", Rivista Diritto Civile I, 2001.

Busto LAGo, José Manuel, La antijuridicidad y la licitud e ilicitud de la conducta, en: Derechos de Daños, Primera Parte, ediciones la Rocca, $1^{\text {a }}$ ed., 1996.

CaAmaño Anido, Miguel Ángel y CALDERÓn CARRERo, José Manuel, "Globalización Económica y Poder Tributario: ¿Hacia un nuevo Derecho Tributario?", en Revista española de derecho financiero, Civitas, № 114, 2002.

Cabanillas Sánchez, Antonio, Las cargas del acreedor en el derecho civil y en el mercantil, Montecorvo S.A., Madrid, 1998.

- "El ámbito de la responsabilidad precontractual o culpa in contrahendo," Revista critica de Derecho inmobiliario, № 68 mayojunio, 1995.

- Los deberes de protección del deudor en el Derecho civil, en el mercantil y en el laboral, Civitas, Madrid, $1^{a}$ ed., 2000.

- "Introducción al estudio de los deberes de protección en el derecho de obligaciones", en Libro homenaje a Luis Rojo Ajura, escritos jurídicos-Santander, Cantabria, 2002. 
- El contrato con efectos protectores para terceros en el Derecho alemán", en Estudios jurídicos en homenaje al profesor Luis Díez-Picazo, t. II., Derecho de obligaciones, Thomson-Civitas, Madrid, 2003.

Calamandrei, Piero, Instituciones del Derecho procesal según el nuevo Código, t. I., trad. Sentís Melendo, Buenos Aires, 1986.

CANARIS, Claus-Wilhelm, "Das Verlöbnis als gesetzliches Rechtsverhältnis, Ein Beitrag zur Lehre von der Vertrauenshaftung", en Archiv für die zivilistische Praxis, 1965.

-Ansprüche wegen positiver Vertragsverletzung und Schutzwirkung fúr Drite bei nichtigen Verträgen, en Juristenzeitung (JZ), 1965.

Cannata, Carlo Augusto, Corso di Istituzioni di Diritto Romano, Turín, Giappichelli, 2003.

- Le obbligazioni in generale, nel Tratt. Rescigno, Vol 9, Torino, 1984.

CARAmés Ferro, José, Curso de Derecho Romano, Buenos Aires, 1958.

CARnelutti, Francesco, Sistema di Diritto processuale civile, t. I, Padova, 1936. 
- Metodología del Diritto, Padova, 1939.

Caroni, Pio, "La historia de la codificación y la historia del Código", en Revista Catalana d'historia del dret, 5, 2000.

- Lecciones de Historia de la Codificación, Dykinson, Madrid, 2013.

CARCATERra, Antonio, "Ancora sulla fides e sui bonae fidei iudicia», en SDHI, XXXIII, 1967.

CastresanA, Amelia, Fides, "Bona fides»: un concepto para la creación del Derecho, Tecnos, Madrid, 1991.

CAstronovo, Carlo, "La relazione come categoría essenziale dell'obbligazione y della responsabilità contrattuale", en Europa e diritto privato, 1, Giuffrè, Milano 2011.

- "Obblighi di protezione" en Enciclopedia Giuridica Trecani, XXI, Roma, 1990.

Carvajal, Patricio, "Artículo 706 del código Civil Chileno: crítica como pretendido núcleo textual del principio de la buena fe" en Estudios de Derecho Civil IV (Dir.) Carlos Pizarro Wilson, Legal Publishing, Santiago, 2009. 
Claro Solar, Luis, Explicaciones de Derecho civil chileno y comparado, vol. V (delas obligaciones), Editorial Jurídica de Chile, Santiago, 1979.

Colin, Ambroise y CAPITANT, Henri, Curso Elemental de Derecho Civil, t. III, $4^{\text {a }}$ ed. Española, editorial Reus, Madrid, 1960.

CoRRAL TALCIANI, Hernán, "La aplicación jurisprudencial de la buena fe objetiva en el ordenamiento civil chileno," en Revista de Derecho Privado, № 12- 13, Madrid, 2007.

Cuadrado Pérez, Carlo, Oferta, aceptación y conclusión del contrato, Publicaciones del Real Colegio de España, Bolonia, 2003.

- La moderna configuración de la doctrina del abuso del derecho, Aranzadi, Madrid, 2014.

D'Angelo, A., "Buona fede", en Tratatto di diritto privato (Dir. M. Bessone), vol. 13.4.2, Torino, 2004.

Demogue, Rene, Traité des obligations en général, sources des obligations, t, I., Librairie Rousseau \& Cie, París, 1925.

De Ángel Yagüez, Ricardo, La responsabilidad civil, $2^{\mathrm{a}}$ ed. Universidad de Deusto, Bilbao, 1989.

- "Puesto que ocupa el Derecho de daños en el Derecho de obligaciones", en Revista Estudios de Deusto, Bilbao, 1995. 
De CuPIS, Adriano, II danno, II Milano, 3ª ed., 1979.

De LA MAZA GAZMURI, Iñigo, Los limites del deber precontractual de información, Thomson Reuters Civitas, Navarra, $1^{\text {a }}$ ed., 2010.

DE Los Mozos, José Luis, El principio de la buena fe. Sus aplicaciones prácticas en el Derecho Civil español, Bosch, Barcelona, 1965.

- Metodología y ciencia del derecho privado moderno, Editorial de Derecho reunidas, Madrid, 1977.

-“Concepto de obligación”, Revista de Derecho Privado, Madrid. 1980.

- "La buena fe en el Título preliminar del Código civil", en Derecho civil. Método, sistemas y categorías jurídicas, Madrid, 1988.

- "Buena fe", en Enciclopedia de la Responsabilidad Civil, Buenos Aires, 1996.

De Castro y Bravo, Federico, Derecho Civil de España, Parte general, t. I., Libro preliminar. Introducción al Derecho Civil, Instituto de Estudios Políticos, Madrid, 1955.

- "Los principios generales del Derecho", en Derecho Civil de España, cap. IV, Civitas, Madrid, 1984.

- Temas de Derecho civil, Madrid, 1972. 
- El negocio jurídico, Civitas, Madrid, 1985.

- Derecho Civil de España, introducción de Luis Díez-Picazo Civitas, Madrid, 1991.

DE LA Oliva, Andrés y FeRnández, Miguel Ángel, Lecciones de Derecho procesal, Barcelona, 1984.

De LA PEZA, José Luis, De las Obligaciones. editorial McGraw Hiil, México, 1997.

DelebequeCque, Philippe, "La dispersion des obligations de sécurité dans les contrats spéciaux" en La naissance de l'obligation de sécurité, Gazette du Palais, 1997.

De Trazegnies Granada, Fernando, "Desacralizando la buena fe en el Derecho" en Tratado de la buena fe en el Derecho, t. II. (Dir.) Marcos M. Córdoba, Editorial La Ley, 1ª ed., Buenos Aires, 2004.

Del Toro Huerta, Mauricio, "El fenómeno del Soft Law y las nuevas perspectivas del Derecho Internacional", Anuario Mejicano de Derecho Internacional, vol. VI, 2006.

Del VeCchio, Giorgio, Los principios generales del Derecho, trad. Juan Ossorio Morales, $3^{\mathrm{a}}$ ed. Bosch, Barcelona, 1971. 
DeZzA, Ettore, Lezioni di Storia della codificazione civile. Il Code Civil 1804 e l'Allgemeines Bürgerliches Gesetzbuch (ABGB, 1812), Giappichelli, 2a edición, Torino, 2000.

Dı MAJO, Adolfo, "Delle obligazioni in generale" en Commentario del Codice Civile Sciloja e Branca, acura de Grancesco Galgano, Bologna-Roma, editore società editrice del foro italiano, 1988.

Di Stefano, "Onere", en Enciclopedia del Diritto, Milano, t. XXX., 1980.

DIEZ-PICAZO, Luis, El contenido de la relación obligacional", en Anuario de Derecho Civil, Madrid, 1964

- Estudios de derecho privado, t. I, Madrid, 1972.

- Experiencia jurídicas y teoría del Derecho, Tecnos, Madrid, 1973.

- Fundamentos del Derecho civil patrimonial, Thomson-Civitas, Madrid, $6^{\mathrm{a}}$ ed., t. II., 2008.

- "A vueltas con la autonomía privada en materia jurídica", en Diario la ley, № 7765, 2011.

Díez-PICAzo, Luis y Gullón, Antonio, Sistema de derecho civil, vol. II: El contrato en general. La relación obligatoria. Contratos en especial. Cuasicontratos. Enriquecimiento sin causa. Responsabilidad extracontractual, Tecnos, 9ª edición, 8ª reimpresión, Madrid, 2003. 
Dreier, Thomas y Hugenholtz, Bernt, Concise European copyright law, Kluwer Law International, 2006.

DÖLlE, Hans, Außergesetzliche Schuldpflichten, Zges, Staats W, 103, 1943.

DOMAT, Jean, Les Lois civiles dans leur ordre natural, en Le Droit public et legum delectus, Paris, chez Th. De Hansy, 1735, I.

DomíngueZ, Ramón, "Los terceros y el contrato" en Revista de Derecho Universidad de Concepción, núm. 174, LI, jul.-dic., 1983.

Domínguez HidAlgo, Carmen, "La indemnización por daño moral. Modernas tendencias en el derecho civil chileno y comparado", en Revista Chilena de Derecho, vol. 25, № 1, 1998.

- "Algunas consideraciones en torno al daño como elemento de la responsabilidad civil", Revista de Derecho, Universidad Católica de Valparaíso, 1998.

DÖRR Zegers, Juan Carlos "Notas acerca de la Teoría de la Imprevisión" en Revista Chilena de Derecho, vil. 12, № 2, 1985.

DucCI CLARO, Carlos Interpretación jurídica, $3^{\mathrm{a}}$ ed., Santiago, Editorial Jurídica de Chile, 1997.

DuPUY, René-Jean, "Droit déclaratoire et droit programmatoire: de la costume sauvage á la soft law", en L'élaboration du droit 
international public, Société française pour le Droit international, Colloque de Toulouse, 1975.

ECHEBARRÍA SÁENZ, Joseba, El contrato de franquicia: definición y conflictos en las relaciones internas, McGraw-Hill, Madrid, 1995.

ElORRIAGA DE BONIS, Fabián, "Del daño por repercusión 0 rebote", en Revista Chilena de Derecho, vol. 26 № 2, 1999.

ENNERCCERUS y LEHMANN, Derecho de obligaciones, vol. № 2, trad., Pérez González y Alguer, Bosch, Barcelona, 1966.

FACCI, Giovanni, II nuovi danni nella famiglia che cambia. Nuovi percorsi di Diritto di Famiglia, 2009.

FAGGELLA, Gabriele, "Dei periodi precontrattuali e Della loro vera ad esatta costruzione scientifica", in Studi guiridici in onore di Carlo Fadda, Napoli, vol. III., 1906.

- I periodi precontratuali e la responsabilità precontrattuale, Roma, 1918.

FASCIONE, Lorenzo, "Cenni bibliografici sulla «bona fides»", en Studi sulla buona fede, en AA. VV. Guiffrè, Milano, 1975.

FAROLFI, F., "L'estensione del danno morale riflesso oltre i casi di morte e di lesioni personali gravi," Nota di commento, Cass. sez III, 21 settembre 2007, en Nuova giur., civ., 2008. 
FranzonI, Massimo, Degli effetti del contratto, en II códice Civile Vol. 2 (Dir.) Schlesinger, Milano, 1999.

FAURE-ABBAD, Marianne Le fait générateur de la responsabilité contractuelle. Contribution à la théorie de l'inexécution du contrat, Librairie Générale de Droit et de Jurisprudence, Paris, 2003.

FERNÁNDEZ DE BUJÁN, Antonio, "El papel de la buena fe en los pactos, arbitrajes y contratos" en Revista de Derecho UNED, Núm. 7, 2010.

Fernández Sessarego, Carlos, Abuso del derecho, Editorial Astrea, Buenos Aires, 2002.

FERRARA, Francesco, "Responsabilidad contrattuale per fatto altrui" en Archivio de Giuridico, vol. LXX, 1903.

FERREIRA RUBIO, Delia Matilde, La buena fe. El principio general en el Derecho Civil, Montecorbo, $1^{\text {a }}$ ed., Madrid, 1984.

FERRI, Luigi, La autonomía privada, Comares, 2001.

FREYBURGER, Gérard, «Fides». Étude sémantique et religieuse depuis les origines jusqu'à l'époque augustéenne, Paris, 1986.

FREZZA, Paolo, «Fides bona», en Studi sulla buona fede, en AA. VV., Guiffrè, Milano, 1975. 
FRIGERIO, Enrique, "La buena fe en el derecho de obligaciones," Revista de la Asociación de Escribanos del Uruguay, t. 55, Montevideo, 1969.

FROST, Marina, Vorvertragliche und vertragliche Schultzflichten, Dunker \& Humblot, Berlín, 1981.

FuenzalidA Puelma, Sergio, "Los terceros en la responsabilidad contractual", en Revista de Derecho y Jurisprudencia № 57 , primera parte, 1960.

FUeyo LANERI, Fernando, Instituciones del Derecho Civil moderno, Editorial Jurídica de Chile, Santiago, 1990.

- Cumplimiento e incumplimiento de las obligaciones, Editorial Jurídica de Chile, Santiago, 1990.

García Amigo, Manuel, Teoría general de las obligaciones y contratos, Lecciones de Derecho civil II, MacGraw-Hill, Madrid, 1995

- "Consideraciones a la buena fe contractual", en Homenaje al profesor Bernardo Moreno Quesada, vol. I, Granada- Jaén- Almería, 2000.

García CANTERo, Gabriel, "El anteproyecto de Código Europeo de contratos- Proyecto Gandolfi o del Grupo de Pavía", en Derecho Privado europeo (Dir. S. Cámara Lapuente), 2003. 
GaRCía GARRIDO, Manuel Jesús, voz «Bona fides», Diccionario de jurisprudencia romana, Madrid, 1986.

García GoYenA, Florencio, Concordancias; motivos y comentarios del Código Civil español, Imprenta Soc. tipográfico, Tomo III, Madrid, 1852.

GARCíA VALDECASAS, Guillermo, "El problema de la acumulación de la responsabilidad contractual y delictual en el derecho español", en Revista Derecho. Privado., t. XLVI, 1962.

- Parte general del Derecho civil español, Civitas, Madrid, 1983.

GARDELLA, Lorenzo, "Principios generales del derecho" en Enciclopedia Jurídica Omeba, t. XXII, Buenos Aires, 1967.

GAUDEMET, Eugene, Teoría General de las Obligaciones, editorial Porrúa, $2^{\mathrm{a}}$ ed., México, 1984.

GLASSON, Ernest, Le Code civil et la question ouvrière, Librairie Cotillon, París, 1886.

GAYA SICILIA, Regina "La influencia del código Civil de Luisana en la Codificación civil española." en Anuario de Derecho Civil, tomo LXIII, fascículo II, Madrid, 2010.

Ghestin, Jacques, Traité de Droit Civil, Les obligations, les effets du contrat, París, 1992. 
- "L'analyse économique de la clause générale", en General clauses and standards in European Contract Law. (Dir.) Stefan Grundmann y Denis Mazeaud, The Hague: Kluwer Law International, 2006.

GoldSTEIN, Paul, El copyright en la sociedad de la información, trad. M ${ }^{\mathrm{a}}$ Luisa Llobregat Hurtado, Alicante, 1999.

GoldschmidT, James, Prozess als Rechtslage, Berlín, Trad. Prieto-Castro, Derecho procesal Civil, Barcelona, 1926.

Gómez CALERo, Juan, La acción subrogatoria, Tesis doctoral [inédita] Universidad de Sevilla, Sevilla, 1958.

Gómez CALLe, Esther, Los deberes precontractuales de información, La ley, Madrid, 1994.

GonZÁlez Delgado José, Responsa lurisperitorum Digesta, vol. V, Universidad de Salamanca, 2004.

GonzÁlez MÉndez, Amelia, Buena fe y Derecho tributario, Marcial Pons, Madrid, 2001.

Gómez RoYo, Enrique, El régimen de las aguas en las relaciones de vecindad en Roma, Valencia, Tirant Lo Blanch, 1997.

Goode, Roy, "The Concept of Good Faith in english Law", en Centro di studi e ricerche di Diritto Comparato e straniero. Saggi, conferenze e seminari, 2 , Roma, 1991. 
Gordillo CaÑAs, Antonio, "Comentarios al art. 1.4 del Código Civil" en Comentarios al Código Civil y Compilaciones Forales, (Dir.) Albarejo y Díaz Albart, Revista de Derecho Privado, Madrid, 1992.

GRONDONA Mauro, "Derecho contractual europeo, autonomía privada y poderes del juez sobre el contrato", en Revista de Derecho Privado, № 22, 2012.

Grosso, Giuseppe, voz "Buona fede (premesse romanistiche)", en EdD No 5, Torino, 1959.

Gustav, Hugo, Historia del Derecho Romano, trad. Manuel Casado Tello, Madrid, 1850.

Guzmán BRITo, Alejandro, Andrés Bello Codificador, Ediciones Universidad de Chile, Santiago, 1982.

-La codificación en Iberoamérica, Editorial Jurídica de Chile, Santiago, 2000.

- "La buena fe en el Código Civil de Chile", en Revista chilena de Derecho, vol. 29, núm. 1, Santiago, 2002.

- Las reglas del "Código Civil" de Chile sobre la interpretación de las leyes, Santiago, Editorial Lexis Nexis, 2007.

- Codificación del Derecho civil e interpretación de las leyes, llustel, Madrid, 2011. 
- "La idea de «principio» mentada en la expresión «principios generales de Derecho»" en Principios Generales de Derecho. Antecedentes históricos y horizonte actual, (Dir.) Fernando Reinoso Barbero, Thomson Reuters, Madrid, 2014.

HALPÉRIN, Jean-Louis, "La naissance de l'obligation de sécurité", Gazette du Palais, 1997.

HART Herbert, El concepto del Derecho, Albeledo Perot, Buenos Aires, 1977.

Henríquez Herrera, lan, "Para una delimitación del efecto expansivo de los contratos" en Revista Chilena de Derecho, vol. 39 NN$^{\circ}$ 2, 2012.

Herrera Bravo, Ramón y Aguilar Ros, Paloma, Derecho romano y Derecho canónico. Elementos formativos de las instituciones jurídicas europeas, Granada, 1994.

HeRnÁNDEZ GIL, Antonio, Conceptos jurídicos fundamentales, Obras completas, t. I. Espasa-Calpe, Madrid, 1987.

- "La posesión como institución jurídica y social", en Obras completas, vol. 2, Madrid, 1987.

HesselinK, M. W., "The principles of European contract Law: some choices made by the Lando Commission", en Principles of European Contract Law, Deventer, 2001. 
Hocquet-Bert, Sophie, Obligation de moyens ou obligation de résultat? À propos de la responsabilité civile du Médicin, Atelier national de reproduction des thèses, Lille, 1995.

HoRvat, M. "Osservazioni sulla «bona fides» nel diritto romano obligatorio", en Studi Arangio-Ruiz , t. I, Milano, 1952.

IGLESIAS, Juan, Derecho romano, Instituciones de Derecho privado II, 1953.

INFANTE CAFFI, Horacio, "El factor de atribución en la responsabilidad civil contractual por el hecho ajeno" en Revista de Derecho y Humanidades, № 7, 1999.

JANA LinetZky, Andrés y TAPIA Rodríguez, Mauricio, "Daño moral en la responsabilidad contractual a propósito de un fallo de la Corte Suprema de 5 de noviembre de 2001, en Cuadernos de Análisis Jurídico, Colección Derecho Privado, №1, 2004.

JHERING, Caspar Rudolf von, Culpa in contrahendo oder Schadenersatz bei nichtigen oder nicht zur Perfection gelangten Vertägen, Jena. 1861, reimpresión Bad Homburg-Berlin-Zürich, 1969.

- De la culpa in contrahendo ou des dommages -interdi dans le conventions nulls ou restées imparfaites. Oeuvres divisies, Trad. por De Meulenaere, tomo II, 1893. 
JIMÉNEZ HORWITZ, Margarita, La imputación al deudor en incumplimiento ocasionado por sus auxiliares, McGraw-Hill, Madrid, 1996.

JOHOW SANTORO, Christian, "La interpretación del contrato y la buena fe" en Estudios de Derecho Civil-Código y dogmática en el Sesquicentenario de la promulgación del Código Civil, Lexis Nexis, Santiago, 2005.

JORDANO FRAGA, Francisco, La responsabilidad contractual, Civitas, Madrid, 1987.

- Obligaciones de medios y de resultado", en Anuario de derecho civil, vol., $44 \mathrm{~N}^{\circ} 1,1991$.

- La responsabilidad del deudor por los auxiliares que utiliza en el cumplimiento, Civitas, Madrid, 1994

JouRdAIN, Patrice, "L'obligation de sécurité. À propos de quelques arrêt récents", en Gazette du Palais, 1993.

- "Responsabilité civile", en Reveu Trimestrielle de Droit Civil, 1993.

- Le fondement de l'obligation de sécurité", en Gazette du Palais 1997.

- Les principes de la responsabilité civile, $6^{a}$ éd., Dalloz, Paris, 2003. 
Josserand, Louis, Cours de Droit Civil Positif Francais, t. II, París, 1932.

- De la responsabilité du fait des choses inanimées, Librairie Nouvelle de Droit et de Jurisprudence, París, 1987.

- "Les transport", en Traité générale théorique et practique de droit comercial, París, 1910.

- Derecho Civil, trad., Santiago Cunchillos y Manterola, ediciones Jurídicas Europa-América, Buenos Aires, t. II, vol. I 1950.

- El espíritu de los derechos y su relatividad, trad., Eligio Sánchez y José María Cajica, Granada, Colmares, 2012.

Kaser, M., lus Gentium, trad. Francisco. J. Andrés Santos, Granada, 2004.

KeLsen, Hans, Teoría pura del Derecho Eudeba, Buenos Aires, 1973.

KLUGER, Viviana, "Una mirada hacia atrás: desde Roma a la Codificación. El recorrido histórico de la buena fe", en Tratado de la buena fe en el Derecho, t. I., (Dir.) Marcos Córdoba, editorial La Ley, $1^{\mathrm{a}}$ ed. Buenos Aires, 2004. 
LACRUZ BERDEJO, José Luis, "Las «concordancias» de García Goyena y su valor para la interpretación del Código civil" en Revista Crítica de Derecho Inmobiliario, marzo-abril, núm. 501, 1974.

- Elementos de Derecho Civil. Derecho de obligaciones, vol. 1. Parte general. Teoría general del contrato, Dykinson. Madrid. t. II, 1999.

- Nociones de Derecho civil patrimonial e introducción al derecho, Dykinson, Madrid, $4^{\text {a }}$ ed., 2004.

LAMBERT FAIVRE, Yvonne, De la responsabilitité encourue envers les personnes autres que la victime initiale: le problème dit du dommage par ricochet, Th., Lyon, 1959.

- Fondement et régime de l'obligation de sécurite, Recueil Dalloz., Paris, 1994.

LANTELLLA, Lelio: "Note emantiche sulle definizioni di "obligatio", en : AA.VV. Studi in onore di Giuseppe Grosso, Torino, Giappichelli, vol. IV , 1971.

- "Fides e Bona fides (proiezioni semantiche ed etiche)", Civiltà europea, 2008.

Lapoyade Deschamps, Christian, Droit des Obligations, Ellipses, París, 1998. 
LARENZ, Karl, Lehrbuch des Schuldrechts, allgemeiner Teil, t.I., $13^{\mathrm{a}}$ ed., München, 1982.

- Derecho de obligaciones, t. I, trad. Jaime Santos Briz, Revista de Derecho privado, Madrid, 1958.

- Culpa in contrahendo Verkehrssicherungspflicht und sozialer Kontakt, MDR, 1954.

- Derecho justo: fundamentos de ética jurídica, trad. Luis DiezPicazo, Civitas Madrid, 1985.

LARRAín Ríos, Teoría general de las obligaciones, Lexis Nexis, Santiago, 2002.

LARROUMET, Christian, "Pour la responsabilité contractuelle", en Études offertes à Pierre Catala. Le Droit privé français à la fin du XX siècle, Litec, Paris, 2001.

LASARTE, Carlos, "Sobre la integración del contrato: la buena fe en la contratación”, Revista de Derecho Privado, Madrid, 1980.

Legaz y LacAmBrA, Luis, Filosofía de Derecho, Bosch, $4^{\mathrm{a}}$ ed., Barcelona, 1975.

Le Tourneau, Philippe, "Contrats et obligations. Classification des obligations. La distinction des obligations de moyens et des obligations de résultt et l'obligation de sécurité" en Juris-Classeur Civil, art. 1091 à 1145, Paris, 1996. 
- Droit de la responsabilité et des contrats, Dalloz, Paris, 2004.

Lete del Rio, Manuel y LeTE AchiRICA, Javier, Derecho de Obligaciones, Thomson-Aranzadi, Madrid, vol. I., 2005.

Liebman, Enrico, Manual de Derecho procesal civil, trad., Sentis Melendo, Buenos Aires, 1980.

LÓPEZ DÍAZ, Patricia "La indemnización compensatoria por incumplimiento de los contratos bilaterales como remedio autónomo en el derecho civil chileno" en Revista Chilena de Derecho Privado, $\mathrm{N}^{\circ}$ 15, 2010.

- "La autonomía de la indemnización de daños en la jurisprudencia nacional reciente: ¿un cambio de paradigma?" en Revista Chilena de Derecho Privado, № 23, 2014.

- La autonomía de la indemnización de daños por incumplimiento de un contrato bilateral en el Código civil chileno, Legal Publisher, Santiago, $1^{\text {a }}$ ed., 2015.

LÓPEZ Mozo, Jerónimo, II Notas Criticas: "La conservación de los regímenes forales y las leyes anteriores al Código civil," en Anuario de Derecho Civil, fascículo I, Madrid, 1951.

LóPez SAnta MARía, Jorge, Los contratos, Parte general, t. II. Editorial Jurídica de Chile, $2^{\mathrm{a}}$ ed., Santiago, 1998. 
LyON-CAEN, Charles y RÉnAult, Lois, Précis de droit commercial I, Librairie Cotillon, París, № 892, 1884.

MAjello, Ugo, Custodia e deposito, Napoli, 1958.

MANCINI, Guiseppe Federico, La responsabilità contrattuale del prestatore di lavoro, Giuffrè, Milano, 1957.

MARTIN BERnAL, José Manuel, El abuso del derecho, Montecorvo S.A, Madrid, 1982.

MARTINE, Edmond, L'option entre la responsabilité contractuelle et la responsabilité délictuelle, Librairie Générale de Droit et de Jurisprudence, Paris, 1957.

Martínez de AguiRre Aldaz, et al, Curso de Derecho civil, Colex, Madrid, vol. II, 2011.

MazeAud, Henri, Lecciones de Derecho civil. Parte segunda, Obligaciones, vol., I, ediciones Jurídicas Europa-América, Buenos Aires, 1978.

Mazeaud Henri, Jean y León, ChaBAs, François, Derecho civil. Obligaciones, t. I. trad. Luis Zavalia, Buenos Aires, 1997.

MAZEAUD, Henri y León, Tunc, Andre, Traité théorique et practique de la responsabilité civile: délictuelle et contractuelle. Lib. du Recueil Sirey, Paris, Vol. I, 1934. 
- Tratado teórico y práctico de la responsabilidad civil, delictual y contractual, t. I, vol. I, traducido por Luis Alcalá Zamora y Castillo, Ejea, Buenos Aires, 1977

MAZEAUD, Denis, Essait et classification des obligations: Obligactions contractuelles et extra-contractuelles, obligations determinées et obligations générale de prudence et diligence" en Revue Trimestrielle de Droit Civil, № 28, París, 1935.

- "Le régime de l'obligation de sécurité," en Gazette du Palais 1997.

MARKESINIS, Basil S., The German law of Torts, Oxford, 1990.

MCKENDRICK, Ewan, "The meaning of 'Good Faith', Liber amicorum Guido Alpa, in Basil Mareskinis et al. (Dir.), London: British Institute of international and comparative law, 2007.

Medicus, Dieter, Tratado de las relaciones obligacionales, vol. I, trad., Ángel Martínez Sarrión, Bosch, Barcelona, 1995.

- Zur entdeckungsgeschichte der culpa in contrahendo, festgabe fur MAXKASER, zum 80, Geburtstag, Wien-Koln-Graz, 1986, p. 23.

MengonI, Luigi, "Obbligazione di resultato e obbligazioni di mezzi” (studio critico), Rivista di Diritto Commerciale, 1954.

- "La parte generale delle obbligazioni", Rivista critica di diritto privato, 1984. 
Menezes Cordeiro, Antonio, Tratado de Direito Civil portugués, Vol. II, Coimbra-Almedina, 2009.

Messineo, Francesco, Manual de Derecho Civil y Comercial, t. IV, ediciones Jurídicas Europa-América, Buenos Aires, 1979.

Micheli, Antonio, Curso de Derecho procesal, trad., Sentís Melendo, Buenos Aires, 1970.

Monsalve Caballero, Vladimir "La buena fe como fundamento de los deberes precontractuales de conducta", en Revista de Derecho, Barraquilla, 2008.

Montes Ángel, Cristóbal, La vía pauliana, Tecnos, Madrid, 1997.

- "Presupuestos y condiciones de la acción paulina", en Revista de Derecho Privado, № 87, 2003.

- "El pago: El papel de la voluntad del acreedor", en Anuario de Derecho Civil, 1986.

Moreno Martínez, José, Daños indirectos en familiares y terceros por causa de lesiones, Cuadernos Aranzadi Civil, Navarra, 2013.

MousouRAKIS, George, Fundamentals of Roman Private Law, Springer Science \& Business Media, Auckland, New Zealand, 2012. 
NATOLI, Ugo, "L'attuazione del rapporto obligatorio, I, II comportamento del creditore", en Trattato di diritto civile e commerciale, (Dir.) Cicu y Messineo, Milano, 1974.

ORdoqui CASTILA, Gustavo, Buena fe contractual, Colección internacional, Bogotá, 2012.

ORti Vallejo, Antonio, "La cuestión de la concurrencia de responsabilidad contractual y extracontractual en los daños por servicios" en La responsabilidad civil por daños causados por servicios defectuosos: estudio de la responsabilidad civil por servicios susceptibles de provocar daños a la salud y seguridad de las personas (Dir.) - ORTI VAlLEJos, Antonio, García GaRnicA, María del Carmen, Thomson-Aranzadi, Navarra, 2006.

PaleRmo, Antonio, Onere, en Novísimo Digesto Italiano, Torino, 1980.

PANTAleón, Fernando, Comentario del código civil, t., II., Ministerio de Justicia, Madrid, 1991.

PASCUAU LIAÑo, Miguel, "Acción revocatoria o pauliana," en Cuadernos Civitas de Jurisprudencia Civil, № 18.

PEÑA LÓPEZ, Fernando, La culpabilidad en la responsabilidad civil extracontractual, Comares, Granada, 2002. 
Peñallillo, Daniel, "La apreciación de la buena fe" en Revista de Derecho Universidad Católica de Concepción, vol. 2, №1, 1993.

PIERI, Geoges, “Obligation”, en Archives de Philosophie du Droit. Vocabulario fundamental du droit, tomo 35, 1990.

PINOCHET OlAVE, Ruperto, "La protección del contratante débil: doctrina de las expectativas razonables", en Gaceta Jurídica N. ${ }^{\circ} 297$, 2005.

PIRENNE, Henri, Historia económica y social de la Edad Media, trad. de S. Echavarri, 10ª reimpr., México, 1970.

PIZARRO, Ramón y VAlLESPINOS Carlos, Instituciones de Derecho privado; Obligaciones, Hammurabi, Buenos Aires, t. I, 1999.

PIZARRO WILson, Carlos, "La responsabilidad contractual en el Derecho Civil chileno", en Fabricio mantilla (coord.), Problemas de Derecho de los Contratos, Bogotá, Editorial Legis, 2007.

- El efecto relativo de los contratos: partes y terceros" en el Código Civil de Chile (1855-20105), trabajos expuestos en el congreso internacional para conmemorar su promulgación, Lexis Nexis, Santiago, 2007.

-“Obligaciones y Responsabilidad Civil. Comentarios de Jurisprudencia" en Revista Chilena de Derecho Privado, №13, 2009. 
Planiol, Marcel y RIPERT, Georges, Derecho Civil, Oxford University pressharla, $1^{\text {a }}$ ed., México. 1999.

PlanIOL, Marcel, Traité élémentaire de droit civil, t. II París, 1912.

- Revue Critique de Législation et de Jurisprudence, París, 1888.

- Tratado Elemental de Derecho Civil, t. II., trad., José María Cajica, Puebla-México, 1945.

POTHIER, Robert Joseph, Tratado de las Obligaciones, editorial Heliasta, Buenos Aires, 1993.

PORTALIS, Jean-Étienne-Marie, Discurso preliminar sobre el proyecto de Código civil, trad. Adela Mora, Universidad Carlos III, Madrid, 2014.

Pradel, Xavier, Le préjudice dans le droit civil de la responsabilité, Libraire Générale de Droit et de Jurisprudence, París, 2004

PRIETO-CASTRO y FerRÁndiz, Leonardo, Tratado de Derecho procesal civil, Pamplona, 1982.

Principios de Derecho Europeo de la Responsabilidad Civil del European Group on Tort Law, AA. VV., (Coord.) Miquel Martín-Casals, trad. (REDPEC), Aranzadi, Navarra, 2008. 
Puig Brutau, José, Fundamentos del Derecho civil. Teoría General del contrato, t. II., Bosch, Barcelona, 1978.

- Introducción al derecho civil, Bosch, Barcelona, 1981.

Puig I FerRiol et al, Manual de Derecho Civil, Marcial Pons, $3^{a}$ ed. Madrid, vol. II., 1996.

PURPURA, Gianfranco, "La «sorte» del debiore oltre la norte: Nihil inter mortem distat et sortem (Ambrogio, de Tobia X, 36-37)", en Iuris Antiqui Historia, t.1. 2009.

Ramos Pazos, Rene, De las obligaciones, Editorial jurídica, Santiago, 1999.

Reglero Campos, L. Fernando, "Conceptos generales y elementos de delimitación" en (Coord.) Reglero Campos, Fernando, Busto Lago, José, Tratado de Responsabilidad Civil t. I., $5^{a}$ ed., Thomson Reuters Aranzadi, Navarra, 2014.

ReINOSo-BARBERO, Fernando, "Los principios generales de derecho en la modernización del lenguaje jurídico", en Principios Generales de Derecho. Antecedentes históricos y horizonte actual, (Dir.) Fernando Reinoso Barbero, Thomson Reuters, Madrid, 2014.

REMY, Philippe, "La responsabilité contractuelle: historie d'un faux concept", Reveu Trimestrielle de Droit Civil, 1997. 
Rescigno, Pietro, Incapacità naturale e adempimento, Edizioni Scientifiche Italiane, 1982.

REZZÓNICO, Juan Carlos, "Efecto expansivo de la buena fe" en La Ley 1991-C.

RIPERT, Georges y Boulanger, Jean, Tratado de Derecho Civil, Las obligaciones, vol. I, ediciones la Ley, Buenos Aires, 1964.

Rivero Hernández, Francisco, Elementos de derecho civil. $T$ I, Parte general del derecho civil. $3^{\circ}$, El derecho subjetivo, José Luis Lacruz Berdejo, Agustín Luna Serrano, Francisco Rivero Hernández, Bosch, Barcelona, 1984.

Roca Guillamon, Juan, "Codificación y crisis del Derecho civil", en AA.VV. Centenario del Código Civil (1889-1999), Editorial Centro de Estudios Ramón Areces, Madrid, 1990.

Rodríguez-ARIAs, Lino, El abuso del derecho, ediciones jurídicas Europa-América, Buenos Aires, 1971.

RODRÍGUeZ BOENTE, Sonia, Los principios generales de derecho, Univ. Santiago de Compostela, 2008.

RODRÍGUEZ ENNES, Luis, "La obligatio y sus fuentes", en Revista Internacional de Derecho romano N 3, 2009.

RodRíguez GonzÁlez, José, El principio de la relatividad de los contratos en el Derecho español, Colex, Madrid, 2000. 
Rodríguez Grez, Pablo, Teoría de la interpretación jurídica, Editorial Jurídica de Chile, $1^{\mathrm{a}}$ ed., Santiago, 1990.

- Responsabilidad extracontractual, editorial Jurídica de Chile, Santiago, 1999.

RODRÍGUEZ OLMOS, Javier, "Deberes de protección `aun frente a terceros' en la doctrina alemana", Revista de Derecho Privado, № 20 , 2011.

Romero PÉREZ, Xiomara, "El alcance del derecho a la intimidad en la sociedad actual", en Revista Derecho del Estado, $N^{\circ}$ 21, 2008.

RopPo, Vicenzo, Instituzioni di diritto privato, Bologña, Monduzzi, $3^{\text {a }}$ ed., 2001.

Rosenberg, Leo, Tratado de Derecho procesal I, Trad. Romera Vera, Buenos Aires, 1980.

Rotond, Mario, L'abuso di diritto, Cedam, Padova, 1979.

RUTHERFORD, Romy, "La "aemulatio" y en el abuso del derecho" en Revista de Estudios Histórico-Jurídicos, XXXV, Valparaíso, 2013.

SAAVEDRA, Francisco Javier, "El principio general de la buena fe" en Instituciones modernas de derecho civil, homenaje al profesor Fernando Fueyo Laneri, (Dir.) Enrique Pérez Levetzow, Editorial Conosur, Santiago, 1996. 
Sacco, Rodolfo, "L'integrazione" en Tratatto de Diritto Privato (Dir.) Pietro Rescigno, t. X, Torino, 1982.

Sainctelette, Charles, De la responsabilité et de la garantie, Bruyland-Christophe-, A. Chevalier-Marescq, Bruxelles-París, 1884.

SalazAr ReVuelta, María, "Formación en el derecho romano y en la tradición romanística del principio de la buena fe y su proyección en el derecho comunitario europeo", en Revista de Derecho Romano Internacional, abril, 2015.

SAleILles, Raymond, Les accidents de travail et la responsabilité civile (Essai d'une théorie objective de la responsabilité délictuelle), Librairie Nouvelle de Droit et de Jurisprudence, París, 1897.

- « Le risque professionnel dans le Code civil», communication à la société d' Economie Sociale, en La reforme Sociale, 1998.

Salinas Araneda, Carlos, "Un influjo frustrado del Derecho Canónico en el Código Civil de Chile: mala fides superveniens nocet". Rev. estudios. históricos.-jurídicos. Núm. 26, Valparaíso, 2004.

SÁnCHEZ-FrierA GonzÁleZ, María del Carmen, La responsabilidad civil del empresario por deterioro del medio ambiente, Bosch, $1^{\text {a }}$ ed., Barcelona, 1994. 
Sandoval López, Ricardo, Derecho del consumidor, editorial Jurídica de Chile, Santiago, 2004.

SAN MARTín NeIRA, Lilian, "La posición dinámica del acreedor en la relación obligatoria..." en Revista de Derecho Universidad de Concepción, № 225-226, 2009.

SANSÓn RodRíguez, María, "La buena fe en el cumplimiento de las obligaciones contractuales en el Derecho romano clásico. Especial referencia al problema de la bilateralidad en los contratos consensuales" en AFDUL, núm. 18, 2001.

SANTOS BRIZ, Jaime, La responsabilidad civil. Derecho sustantivo y Derecho procesal, I, 5a ed., Madrid, 1989.

SARMIENTO RAmírEZ-ESCUdERO, Daniel, "La autoridad del Derecho y la naturaleza del soft law", en Cuadernos de Derecho Público, № 28, 2006.

SAUZET, Marc, "De la responsabilité des patrons vis-à-vis des ouvriers dans les accidents industriels", en Revue Critique Législation et. Jurisprudence, 1883.

SaVATIER, René, "Le prétendu principie de l'effet relatif des contrats" en Reveu Trimestrielle de Droit Civil, 1934.

SAVAUX, Eric, "La fin de la responsabilité contractuelle?", en Reveu Trimestrielle de Droit Civil, 1999. 
Segura Riveiro, Francisco, "La buena fe, un aspecto de tensión entre los sistemas jurídicos" en Estudios de Derecho Civil V, Legal Publishing, Santiago, 2010.

Sepúlveda lorroucau, Marco, "Los grandes principios que inspiran al Código civil chileno" en Estudios de Derecho civil, grafica Kolbe, Santiago, 2007.

SCHERILLO, Gaetano: "Le definizioni romane delle obbligazioni", en AA.VV. Studi in onore di Giuseppe Grosso, Torino, Giappichelli, vol. IV, 1971.

SCHMIDT, Jürgen, "§ 242" en J. Von Staudingers Kommentar zum Bürgerlinchen Gesetzbuch mit Einführungsgesetz und Nebegesetzen. Zweites Buch Recht der Schuldverhältnisse. Dreizehnte Bearbeiteung, Berlín, Nº 51, 1995.

SCHMIDT, Peter Jan, "Sentencias famosas: Alemania. Sobe el caso de los rollos de linóleo", Revista de Derecho Privado, № 24 , 2013.

SCHNEIDER, Winfried-Thomas, Abkehr vom Verschuldensprinzip, Mohr Siebeck, Tübingen, 2007.

Scognamiglio, Renato, voz "Responsabilità per fatto altrui" en Novissimo Digesto italiano XV, Torino, 1968.

-"Responsabilità contrattuale ed extracontrattuale", Novissimo Digesto Italiano, XV, Torino, 1980. 
ScoozzAFava, "Onere", en Enciclopedia de Diritto, t XXX, Torino, 1980.

SIBER, Heinrich, Sculdrecht, Leipzig, 1931.

StaUB, Hermann, "Die positiven Vertragsverletzungen", Berlín, 1904.

StIGLITZ, Rubén, Contratos civiles y comerciales. Parte general, Abeledo Perrot, Buenos Aires, 1998.

- "La información precontractual y contractual de información el deber de consejo" en Estudios sobre consumo, Madrid, 1997.

STOLFI, Emanuele, "Bonae fidei interpretatio». Ricerche sull'interpretazione di buona fede esperienza romana e tradizione romanistica, Napoli, 2004.

STOLL, Heinrich, Haftung für das verhalten während der Vertragsverhandlungen, LZ, 1923.

- Abschied von der Lehre del positiven Vertragsverleztung" en Archiv für di civilistisch, Praxis, 1932.

SIRVENT GARCíA, Jorge, La acción subrogatoria, Colección Monográficas Universidad Carlos III, Madrid, 1998. 
Solarte RodRíguez, Arturo, "La buena fe contractual y los deberes secundarios de conducta," en Revista Universitas, Bogotá, № 108, 2004.

SolEIL, Sylvain, "El Código Civil de 1804 ¿ha sido concebido como un modelo jurídico para las naciones?", trad. por Sebastián Ríos Labbé, en María Dora Martinic G. y Mauricio Tapia R. (Dir.) Sesquicentenario del Código Civil de Andrés Bello. Pasado, presente y futuro de la codificación, Lexis Nexis, 2005.

SUMMERS, Robert, "The conceptualization of good faith in American contract law: a general account" in Good faith in European Contract Law, Reinhard Zimmermann \& Simon Whittaker (Dir.) Cambridge, University Press, 2000.

TALAMANCA, Mario, «La tipicità dei contratti romani fra 'conventio' e 'stipulatio' fino a Labeone», en Contractus e pactum, Atti del convegno di diritto romano e della presentazione della nuova riproduzione della littera Florentina, a cura di F. Milazzo, Napoli 1990.

TARdío PATO, José Antonio, Los principios generales del Derecho, Bosch, Barcelona.

Terre François, Simler, Philippe, Lequette, Yves, Droit Civil. Les Obligations, $8^{\text {a }}$ éd., Dalloz, Paris, 2002.

TESSITORE, T, Buona fede e responsabilità precontrattuale, Milano, 1975. 
TOMAS Y VAliente, Francisco, "La Codificación. De utopía a técnica vulgarizada", en Luis Michelena Elissalt y José Melena L. (Dir.), Universidad del País Vasco, Vitoria-Gasteiz, 1985.

URbano SaleRno, Marcelo, Obligaciones, régimen jurídico, editorial Universidad, Buenos Aires, 1995.

VALÉs DuQUe, Pablo, La responsabilidad precontractual, Reus, Madrid, 2012.

VALDIÑo ARcos, Alejandro, La aemulatio en el Derecho romano: su examen en sede de relaciones de vecindad y de calumnia procesal, Ediciones del Instituto de Historia del Derecho Juan de Solórzano y Pereira, Santiago, 2002.

VATtier FuenzalidA, Carlos, "Los daños de familiares y terceros por la muerte o lesiones de una persona" en Centenario del Código Civil, Il, Madrid, 1990.

Vavasseur, M, August, De la responsabilité des accidents de fabrique, Marchal-Billard Et, París, 1881.

Veaux-Fournerie, Paulette - Veaux, Daniel, L'obligation de sécurité dans la vente, Litec, Paris, 2002.

VECCHI, Paolo María, "Buona fede e relazioni successive all'esecuzione del rapporto obligatorio", en $A A$. VV., II ruolo della buona fede oggettiva, vol. IV, Padua, 2003. 
Venosta, Francesco, "Profili della disciplina dei doveri di protezione" en Rivista di diritto civile, Anno LVII, № 6, Milano, 2011.

VICENTE Domingo, Elena, Los daños corporales: Tipología y valoración, Bosch, Barcelona 1994.

- en (Coord.) Reglero Campos, Fernando, Busto Lago, José, Tratado de Responsabilidad Civil t. I., $5^{\mathrm{a}}$ ed., Thomson Reuters Aranzadi, Navarra, 2014.

VIDAL OlivaRes, Álvaro, "La responsabilidad del deudor por incumplimiento de su tercero encargado en la compraventa internacional de mercaderías", en De la Maza Gazmuri, Iñigo (editor), Cuadernos de análisis jurídico. Colección derecho privado, III: Temas de contratos, Santiago, Ediciones Universidad Diego Portales, 2006.

- "El efecto absoluto de los contratos" en Revista Chilena de Derecho, núm. 6, 2006.

- "Cumplimiento e Incumplimiento contractual en el Código Civil. Una perspectiva más realista", en Revista Chilena de Derecho, № 34 , Santiago, 2007.

VILLORO TORANZO, Miguel, Las relaciones jurídicas, editorial Jus, $2^{\mathrm{a}}$ ed., México, 1976.

VINEY, Genevieve, "Le dommage inditect ou par ricochet en Droit français" en Développements récents du Droit de la responsabilité civile, Zürich, 1991. 
- "Rapport de synthèse", en La naissance de l'obligation de sécurité, Gazette du Palais, 1997.

VINEY, Genevieve, JouRdAIn, Patrice, "Les conditions de la responsabilité", en Jacques Ghestin (sous la direction), Traité de Droit Civil, Librairie Générale de Droit et de Jurisprudence, $3^{a}$ éd., París, 2006.

VINEY Genevieve y MARKESINIS Basil, La réparation du dommage corporel: Essai de comparaison des droits anglais et français, Paris, 1985.

VISINTINI, Giovanna, "Inadempimento e mora del debitore", en /I códice Civile (Dir.) Schlesinger, Milano, 1987.

- I fatti illeciti. Ingiustizia del danno, Ed. Padova, Cedam, 1996, reimpr. 2004.

Von TUHR, A., "La buena fe en el Derecho romano y en el actual", en Revista de Derecho Privado, № 146, Madrid, 1925.

VOYENNE, Bernard, Le droit à l'information, Aubier Montaigne, París, 1970.

VV. AA. Primer Proyecto de Código Civil de Chile, Santiago, Editorial Jurídica de Chile, 1978. 
Welsch, Sylvie, Responsabilité du médecin, Collection Pratique Professionnelle, Juris Classeur, Editions Litec, $2^{\text {ème }}$ ed., Paris, 2003.

Werner Carolina y NeHme Nicole, "El rol de los conceptos de orden público, buenas costumbres y buena fe en la contratación entre partes desiguales" en Sesquicentenario del código Civil de Andrés Bello, (Dir.) María Dora Martinic y Mauricio Tapia, Lexis Nexis, Santiago, 2005.

WIEACKER, Franz, El principio general de la buena fe, trad. José Luis Carro, Civitas, Madrid, 1982.

WINKEL, Laurens "Some historical remarks on the use of open norms in Dutch private law: good faith in contract, social decency in tort", in Wacław Uruszczak et al. (eds.), Leges sapere, Studia i prace dedykowane prof. J. Sondlowi (Studies for Janusz Sondel), Cracovia, 2008.

YZquiERdo TolsadA, Mariano, Sistema de responsabilidad civil, contractual y extracontractual, Dykinson, $1^{\text {a }}$ ed., Madrid, 2001.

ZELAYA, Pedro, "La responsabilidad civil por el hecho ajeno y el seguro" en Revista Chilena de Derecho, vol. 29, № 1, 2002.

ZENS, Albert, De la responsabilité du voiturier à raison des accidents de personnes, Thèse, París 1896.

ZIMMERMANN, Reinhard, Law of Obligations. Roman Foundations of the Civilian tradition, Juta \& Co. Ltd., Cuidad del Cabo, 1992. 
- "Rasgos fundamentales de un Derecho contractual europeo", en Estudios de Derecho Privado, Madrid, 2000.

- El nuevo Derecho de alemán de obligaciones, trad. Esther Arroyo, Boch, Barcelona, 2008.

ZIMMERMANN, Reinhard \& WhITTAKER Simon et al., Good Faith in European Contract Law. Cambridge: Cambridge University Press., 2000.

ZUBIRI DE SALINAS, Mercedes, La responsabilidad civil del transportista en el contrato de pasaje marítimo, Bosch, Barcelona, 1995. 


\section{JURISPRUDENCIA}

1.- Alemania

Sentencia 7 de diciembre de 1911, del Reichsgericht (RGZ), en Entscheidungen des Reichsgerichts in Zivilsachen, $\mathrm{N}^{\circ}$ 28, 1912, pp. 239-241.

$>$ Sentencia de 19 de julio de 1914, (RGZ) en Entscheidungen des Reichsgerichts in Zivilsachen, 1915, pp. 185 y ss.

D Sentencia de 15 de marzo de 1915, (RGZ) en Entscheidungen des Reichsgerichts in Zivilsachen, 1915, pp. 321 y ss.

> Sentencia del 2 de julio de 1915, (RGZ) en Entscheidungen des Reichsgerichts in Zivilsachen, 1916, pp. 128 y ss. 
Sentencia del 26 de septiembre de 1961, del Bundesgerischtsof (BGH), en Neue Juristische Wochenschrift. 1962, p. 31.

> Sentencia 28 de enero de 1976, BGH, en Entscheidungen des Bundesgerichtshofs in Zivilsachen, $N^{\circ} 66,1977$, pp. 51 y ss.

2.- Francia

Sentencia del 21 de noviembre de julio de 1911, "Zbidi Hamida Ben Mahmoud con Compagnie génerale transatlantique", Cour de Cassation en Dalloz. Recueil pédiodique et critique de jurisprudence, de législation et de doctrine, 1913, p. 249.

$>$ Sentencia 7 de marzo de 1989, Cour de Cassation en Reveu Trimestrielle de Droit Civil (RTDC), 1989, p. 550.

$>$ Sentencia 10 de enero de 1990, Cour de Cassation en RTDC, 1990, p. 483.

$>$ Sentencia 22 de marzo de 1991, Cour de Cassation en RTDC, 1991, p. 758. 
> Sentencia 4 de noviembre de 1992, Cour de Cassation en RTDC, 1993, p. 367.

3.- España

> Sentencia 17 enero de 1995, Cour de Cassation en RTDC, 1995, p. 634.

$>$ Sentencia de 6 de abril de 1988 Tribunal Supremo (Sala de lo Civil), (RJ 1988/3111).

Dentencia del 9 de octubre de 1993, Tribunal Supremo, (RJ 1993/8174).

> Sentencia de 17 de febrero de 1996, Tribunal Supremo, (RJ 1996/1408).

$>$ Sentencia de 30 de junio de 2000, Tribunal Supremo, (RJ 2000/6747).

4.- Chile 
> Sentencia de 16 de diciembre de 1922, Corte Suprema en Revista de Derecho y Jurisprudencia $(R D J)$ t. XXI, sec. $1^{\mathrm{a}}, \mathrm{p}$. 1053.

> Sentencia de 14 de agosto de 1928, Corte Suprema en $R D J$, t. XXVI, sec. $1^{\mathrm{a}}$, p. 141.

> Sentencia de 19 de enero de 1990, Corte de Apelaciones de Concepción, en Gaceta Jurídica (GJ) N¹22, 1990, p. 31.

Sentencia de 20 de octubre de 1994, Corte Suprema en GJ N 174, 1994, p. 155.

$>$ Sentencia de 6 de agosto de 1996, Corte de Apelaciones de Santiago, en GJ N 194, 1996, p. 70.

$>$ Sentencia de 25 de noviembre de 1998, Corte de Apelaciones de Santiago en GJ, N ${ }^{\circ} 221$, pp. 200 y ss.

> Sentencia de 19 de enero de 1999, Corte de Apelaciones de Santiago en GJ, N²23, pp. 209 y ss. 
Sentencia de 28 de enero de 1999, Corte Suprema en $R D J$, t. XCVI, sec. $4^{\mathrm{a}}$, p. 71.

> Sentencia de 13 de marzo de 1999, Corte Suprema en Fallos del Mes (F. del M.) No 485, p. 302.

> Sentencia de 27 de mayo de 1999, Corte Suprema en $R D J$, t.96, sec. $3^{\text {a }}$, pp. 89 y ss.

$>$ Sentencia de 17 de enero de 2000, Corte de Apelaciones de Santiago en GJ, N²35, pp. 199 y ss.

> Sentencia de 8 de agosto de 2000, Corte Suprema en $R D J$, t. 97, sec. $3^{\text {a }}$, pp. 152 y ss.

> Sentencia de 25 de octubre de 2000, Corte de Apelaciones de Santiago en GJ, N ${ }^{\circ} 245$, pp. 233 y ss.

> Sentencia de 19 de diciembre de 2000, Corte Suprema, en Gaceta Jurídica GJ Nº 246, p. 122. 
Sentencia de 25 de septiembre de 2001, Corte Suprema en F. del M., Nº 502, p. 2784.

> Sentencia de 29 de enero de 2002, Corte Suprema en GJ, $\mathrm{N}^{\circ} 259$, p. 17.

$>$ Sentencia de 20 de mayo de 2002, Corte de Apelaciones de Concepción en GJ, № 270, pp. 160 y ss.

> Sentencia de 19 de agosto de 2003, Corte Suprema en GJ, $N^{\circ} 278$, p. 252.

$>$ Sentencia de 26 agosto de 2003, Corte Suprema en $F$ del M., N $\mathrm{N}^{\circ} 513$, p. 2155.

> Sentencia de 02 octubre de 2003, Corte Suprema en GJ, $\mathrm{N}^{\circ} 280$, p. 279 ss.

$>$ Sentencia de, 21 de noviembre de 2003, Corte de Apelaciones de Rancagua en Lexis Nexis № 29895. 
Sentencia 20 de enero de 2003, Corte Suprema en $F$ del $M, \mathrm{~N}^{\circ} 506, \mathrm{pp} .5267$ y ss.

$>$ Sentencia de 5 de junio de 2006, Corte Suprema, Rol № 6118-2005.

> Sentencia de 3 de julio de 2007, Corte Suprema Rol № 5939-2005, “I. Municipalidad de Quilpué con MONTEC S.A.”

$>$ Sentencia del 28 de enero de 2008, Corte de Apelaciones de Santiago, Rol N 3180-2003, "AGF Allianz Chile Compañía de Seguros Generales S.A. con Inversiones Paseo del Mar S.A. y otro."

> Sentencia de 7 de diciembre de 2010, Corte Suprema, Rol No 3341-2009, "Opazo Lamana con Inmunomédica Lab. Ltda.," en Legal Publishing, № 47448.

> Sentencia de 29 de marzo de 2011 Corte Apelaciones de Concepción, Rol No 1258-2011, "Faúndez Mora con Cía. de Telecomunicaciones de Chile S. A.," en Legal Publishing, $\mathrm{N}^{\circ}$ 4856. 
> Sentencia de 31 de agosto de 2011, Corte Suprema, Rol NN 1061-2010, "Asoc. De Productores de huevos de Chile con Banco de Chile, en Vlex Nº 333763730.

$>$ Sentencia de 10 de julio de 2012, Corte Suprema, Rol No 4328-2012, "Reyes Valdivia con Escuela de Tripulantes y Portuaria, en Legal Publishing CL/JUR/1308/2012.

> Sentencia de 28 de enero de 2013, Corte Suprema, Rol № 5898-2012, "Ampuero Ascencio con Castillo Hernández" en Legal Publishing CL/JUR/174/2013.

> Sentencia 10 de septiembre de 2013, Corte Suprema, Rol № 885-2013, "Steffen Cáceres con Fundación Mi Casa" en Legal Publishing CL/JUR/2008/2013.

> Sentencia 2 de octubre de 2013, Corte Suprema, Rol No 8607, "Stange Hofman con Ripley Puerto Montt, en Microjuris $N^{\circ}$ MJJ36038. 
Sentencia de 26 de noviembre de 2014, Corte Suprema, Rol № 14.008-2013, "Laboratorio de Control Técnico Llay Llay con Celestron Ltda." en Vlex 566140998. 
JURISPRUDENCIA 